


\section{DISCLAIMER}

This report was prepared as an account of work sponsored by an agency of the United States Government. Neither the United States Government nor any agency Thereof, nor any of their employees, makes any warranty, express or implied, or assumes any legal liability or responsibility for the accuracy, completeness, or usefulness of any information, apparatus, product, or process disclosed, or represents that its use would not infringe privately owned rights. Reference herein to any specific commercial product, process, or service by trade name, trademark, manufacturer, or otherwise does not necessarily constitute or imply its endorsement, recommendation, or favoring by the United States Government or any agency thereof. The views and opinions of authors expressed herein do not necessarily state or reflect those of the United States Government or any agency thereof. 


\section{DISCLAIMER}

Portions of this document may be illegible in electronic image products. Images are produced from the best available original document. 


\section{NOTICE}

This report was prepared as an account of work sponsored by the United States Government. Neither the United States nor the United States Department of Energy, nor any of their employees, nor any of their contractors, subcontractors, or their employees, makes any warranty, express or implied, or assumes any legal liability or responsibility for the accuracy, completeness or usefulness of any information, apparatus, product or process disclosed, or represents that its use would not infringe privately owned rights.

This report has been reproduced directly from the best available copy.

Available from the National Technical Information Service, U.S. Department of Commerce, Springfield, Virginia 22161.

Price: Paper Copy $\$ 9.00$

Microfiche $\$ 3.00$ 


\title{
GEOLOGIC AND GEOCHEMICAL STUDIES OF THE NEW ALBANY GROUP IN ILLINOIS (DEVONIAN BLACK SHALE) \\ TO EVALUATE ITS CHARACTERISTICS AS A SOURCE OF HYDROCARBONS
}

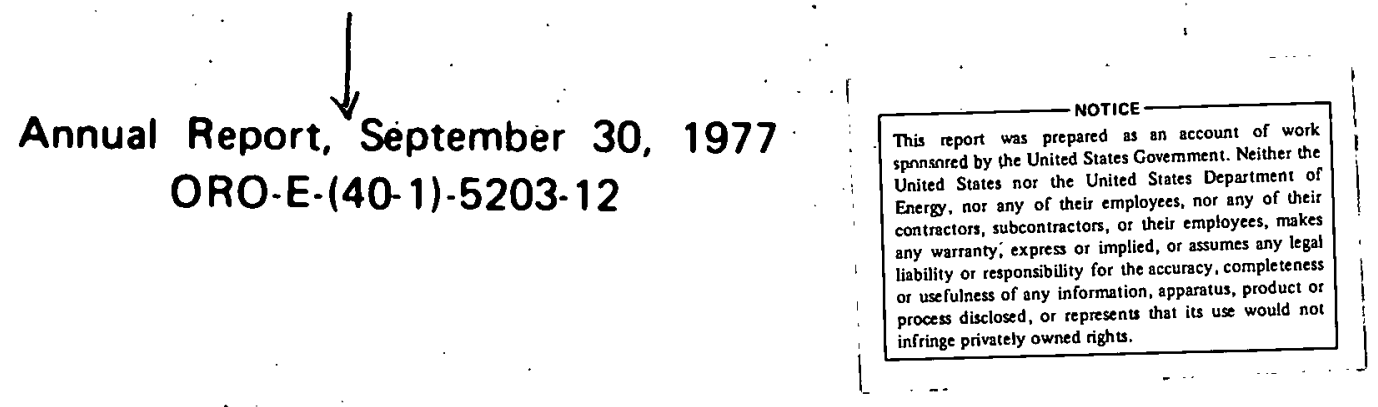 \\ Submitted to \\ U.S. ENERGY RESEARCH AND DEVELOPMENT ADMINISTRATION \\ Contract E-(40-1)-5203
}

Robert E. Bergstrom and Neil F. Shimp,
Principal Investigators

University of Illinois/lllinois State Geologica! Survey 


\section{Table of Contents}

Acknowledgments

vili

Abstract

Int roduction

Sample numbering system.

IG. Strat1graphy and structure of New Albany In Illino1s SCONE AND FURFOSE

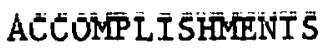

METHODS

RESULTS AND DISCUSSION

Core summaries

Preparation of cross-sections and maps from subsurface data

Geophysical characterization of Iithologic types

Stratigraphic correlations

Formal stratigraphic nomenclature . $\quad 26$

Blocher Shale 27

Sylamore Sandstone 27.

Sweet land Creek Shale 27

Grassy Creek Shale , . . . 27

Saverton shale 28

Loulstana Limestone 28

"Glen Park" Formation 28

Hannibal Shale : 28

Formations defined in.terms of facles 29

Stratigraphic relationships of New Albany

Group to underlying and overlying strata 29

Linear features visible on LANDSAT 1mages

of Western Illinols : 30

Basic data file for Eastern Gas Shales

Project $\quad 32$

REFERENCES

IIG. Mineralogio and potrographio characteribation of

New Alhany in Illi1nois $\quad \cdot \quad:-40$

$\begin{array}{ll}\text { SCOPE AND PURPOSE } & 40\end{array}$

ACCOMPLISHMENTS $\quad 40$

METHODS OF ANALYSES AND PROCEDURES

Analyses . 41

Procedures $\quad 41$

RESULTS

45

Location and stratigraphic position of samples studied

4500 S11t and trace constituents 45 
Clay mineralogy $\quad 49$

Clay orientation index 49

Petrography-Macrocharacterization 54

Petrography-Microcharacterization 57

Texture and structure $\quad 57$

Paleontology 57

Diagenetic features $\quad 59$

Particle orientation $\quad 60$

Dispersed organic matter and vitrinite reflectance

Mineralogy

Petrography

Concept of petrographic 1ithofacies and its application to shales 67 Lithofacies of the New Albany 68

Lithofacies I

Relation of lithofacies to physical properties

Sumary of progress on studies of other REFERENCES cores

IIIG. Analysis of physical properties of the Devonian

Black Shale SCOPE AND PURPOSE . $\quad 80$

ACCOMPLISHMENTS $\quad \therefore \quad 80$

METHODS ... . . 81

RESULTS : $\quad 84$

DISCUSSION OF RESULTS. 84

IVG. Mineral resources evaluation system 91

$\begin{array}{ll}\text { SCOPE AND PURPOSE } & 91\end{array}$

ACCOMPLISHMENTS . : . . . 91

METHODS . $\quad 91$

RESULTS 94

DISCUSSION OF RESUI.TS $\quad 95$

REFERENCES $\quad 96$

IC. Quantitative determination of major, minor, and

trace elements in Eastern U.S. shales. 97

SCOPE AND PURPOSE . . 97

$\begin{array}{ll}\text { ACCOMPLISHMENTS } & 97\end{array}$

METHODS : . 97

Instrumental neutron activation analys is (NAA) 97

Optical emission spectroscopy. 98

Preparation of symthetic shale standards

Photographic optical emission spectroscopy (OE-P)

Direct-reading optical emission spectroscopy (9oe-D)

$X$-ray fluorescence analysis. (XRF) 
Ion-selective electrode analysis for

fluorine

103

Other methods of analysis 103

RESULTS 104

DISCUSSION 104

REFERENCES 112

IIC. Trace element distribution between shale inorganic

and organic phases

SCOPE AND PURPOSE 114

RESULTS 114

$\begin{array}{cc}\text { IIIC. Mode of occurrence and relative distribution } & \\ \text { of hydrocarbon phases in shale } & 115\end{array}$

SCOPE AND PURPOSE 115

ACCOMPLISHMENTS 115

METHODS 116

Hydrocarbons $\quad 116$

Isotopes $\quad 116$

RESULTS AND DISCUSSION 118

Hydrocarbons $\quad 118$

Ieotopes 118

Christian County, KY, core 118

Effingham County, IL, core 129

LABORATORY STUDY OF GAS FRACTIONATION 132

REFERENCES 135

IVC. Adsorption/desorption studies of gases through 136

$\begin{array}{ll}\text { hales } & 136 \\ \text { SCOPE AND PURPOSE } & 136\end{array}$

ACCOMPLISHMENTS 136

METHODS 137

RESULTS AND DISCUSSION 137

REFERENCES 146

$\begin{array}{ll}\text { Summary and conclusions } & 147\end{array}$

Appendix A: Annotated bibliography of the New Albany
Shale and ils equivalents in Illinols

Appendix B: Annotated bibliography of the New Albany

Shale and its equivalents in the region adjacent to Illinois

Appendix C: Task milestones

163
178

\section{LIST OF TABLE3}

Tahle 1 Mineralogic and petrographic analyses, methods and types of samples

2 Silt mineralogy, (O1IL) 46

3 Silt mineralogy, (01KY) 47

4 Clay mineralogy and urientation index, (OIIL) sn

5 Clay mineralogy and orientation index, (O1KY) 51

6 Petrography-macrocharacterization, (OIIL) 55

7 Petrography-macrocharacterization, (01KY) 56

8 Vitrinite reflectance, (OIIL) 62

9 Vitrinite reflectance, (01KY) 63

10 Lithofacies characteristics 69

11 Status of core distribution and sampling 85

12 Status of index property testing 86

13 Concentration of major and minor elements in
shale standard matrix 
Composition of standards for spetroscopic analysis of shales

Operating parameters for emission spectroscopy

Elements determined by optical emission spectroscopy and emission lines detected 102

Chemical data on Christian County, Kentucky, core

Chemical data on Sangamon County, Illinois, core 108

Selected compilation of literature data on elemental concentrations in Earth's crust and shales

20 Composition of total headspace gas, (01KY)

Composition of total headspace gas, (02IL)

Composition of off-gas, (01KY)

Composition of off-gas, (02IL)

Core characteristics, (01KY)

25 Core characteristics, (02IL)

26 Carbon-isotopic composition of methane from core $01 \mathrm{KY}$

27 Carbon-isotopic composition of methane from core $02 \mathrm{IL}$

28 Internal surface area values for shale samples from core $01 \mathrm{KY}$

Internal surface area values for shale samples from core 01IL

30 Internal surface area values for shale samples from core $02 \mathrm{IL}$

31 Internal surface area values after different outgassing temperatures for sample 01Cl from the Christian County, Kentucky, core (01KY)

32. Density and porosity values for selected shale samples from Sanagmon County, Illinois, core (01.1I.)

\section{LIST OF FIGURES AND PLATES}

Figure 1 Tectonic setting, locations of cores and wells used in cross-sections.

2a Stratigraphic section of Christian County, Kentucky, core (01KY), approximate depths from which samples were taken, and generalized lithologic.description. 9

$2 b$ Explanation of lithologic symbols used in figures 2 to 9.

3a Stratigraphic section of Sangamon County, Illinois, cule (0.1L), approximate depths from which samples were taken, and generalized lithologic descriptions.

3b Sangamon County, Illinois, core (lower portion) 12

4 Stratigraphic section of Effingham County, I1linois, core $(02 \mathrm{~L})$, approximate depths from which samples were taken, and generalized lithologic descriptions.

5a Stratigraphic section of Henderson Cuunly, Llinois, core (04IL), approximate depths from which samples were taken, and generalized lithologic descriptions. 
$5 b$ Henderson County, Illinois, core (lower portion)

6a Stratigraphic section of Tazewell County, Illinois, core (06IL) and generalized lithologic descriptions.

6b Tazewell County, Illinois, corc (lower portion).

7 Northwest-southeast cross-section (04IL-01KY) (3 parts) using geophysical logs, core studies, and sample studies.

8 Southwest-northeast cross-section $M-P$, using geophystcal logs, core study, and sample studies.

9 West-east cross-section Q-K, using geophysical logs.

Preliminary isopach map of the New Albany Shale Group, compiled from cross-section data.

11 LANDSAT image of western Illinois taken 14 January 1974.

12 Index map showing area in which the basic data file for holes penetrating the upper Devonian Shales has been completed. Devonian well locations, NE area.

Devonian well locations, SE area.

Devonian well locations, SW area.

17 Diagram showing the procedures used to obtain samples for mineralogic and petrographic and chemical analyses from core segments of New Albany shales.

18 Diagram of processing and preparation of samples of New Albany shales for mineralogic, petrographic, and geochemical analyses at. the Illluvis State Geological Survey.

Clay mineral composition of samples raken from the Kentucky and Illinois rores.

Orientation index of the clay minerals.

21 Mean-random reflectance, in oil, Sangamon County,

21 Mean-random reflectance, in oil, Sangamon County,
Illinois, samples (01L).

22 Mean-random reflectance, in oil, Christian County,

Kentucky, samples (OlKY).
Relatiun of 1 evel. of organic metamorphism (J.OM), coal rank, various measures of rank in sediments, and the principal stages of oil and gas generation.

24 Kelation of 11chofacies classification to (A) internal. aurface area ratio, (B) shore hardness index, and (C) clay orientation index. Work plan for core routing and analysis of directional properties.

Data sheet used to record information about physical properties and distribution of samples. 83

Index properties, 01KY core.

Index properties, 02IL core.

Index properties, 04IL core.

Index properties, 06IL core.

31 Aluninum cannister used for off-gas determinations. 117 
32 Adapter used to monitor pressure in aluminum cannisters and to collect gas samples.

34 Hydrocarbon composition as a function of depth for gas samples from core 0IKY.

35 Comparison of the isotopic composition of methane to the vitrinite reflectance of the associated shale.

36 Maturity plot for gas samples from core 02IL.

37 Changes in the composition of the off-gas during the first $4 \mathrm{hr}$ of off-gassing.

38 Composition of the off-gas during the final stage of the degassification experiment.

39 Relationship between $\mathrm{CO}_{2} / \mathrm{N}_{2}$ ISA and organic carbon content for shale samples from Christian County, Kentucky (core 01KY).

40 Relationship between $\mathrm{CO}_{2} / \mathrm{N}_{2}$ ISA and organic carbon content for shale samples from Sangamon County, Illinois (core 01IL).

41 Methane adsorption isotherms at $28^{\circ} \mathrm{C}$.

42 Methane sorption (and adsorption) isotherms at $28^{\circ} \mathrm{C}$.

\section{LIST OF PLATES}

Plate 1. (A) Fine silt laminae in brownish-black shale. Sample 01KY08Cl.

(B) Compressed burrow with silt-rich filling. Sample 01KY08Cl.

(C) Rounded, fine sand grains concentrated within a burrow filling. Sample 01KY08C1.

(D) Flattened spores. Sample 1KY03L1.

(E) Several phosphatic fossil fragments scattered in a silt layer. Sample 01KY07Ll.

Plate 2. Bioturbate greenish-gray mudstone.

Plate 3. Indistinctly bedded olive-gray shales.

(Lithofacies II-A and II-B).

Plate 4. Poorly laminated brownish-black shales. (LIthofacies III-A and III-B).

Plate 5. Finely laminated brownish-black shales. (Lithofacies IV-A and IV-B). 


\section{Acknowledgments}

Studies of the New Mlbany Group were under the general direction of Robert E. Bergstrom and Neil F. Shimp, Principal Investigators for geology and geochemistry respectively. The investigators who conducted the scientific studies and produced the results reported here are listed as authors of the iudividual piojects.

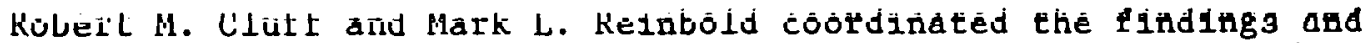
conclusions from the various projects in the production of this tirst amual report. The Principal Investigators gratefully acknowledge their thorough efforts.

Additional contributors were: J. F. Ashby, W. D. Brigham, D. A. Burke, B. Cardott, P. J. DeMaris, E. Fruth, A. E. Giobbe, S. Hampton, L. R. Henderson, J. P. Hoeflinger, E. Hopke, L. Kohlenberger, R. Koszykowski, A. Leeds, J. Maronne, D. P. Miller, J. Risatti, M. Siefrid, J. Steele, T. Walker, and B. Witek. 


\begin{abstract}
The Illinois State Geological Survey is conducting geological and geochemical investigations to evaluate the potential of New Albany Group. shales as sources of hydrocarbons, particularly natural gas. Geoiogical studies include stratigraphy and structure; mineralogic and petrographic characterization; analyses of physical properties; and development of a computer-based resources evaluation system. Geochemical studies include quantitative determination of 49 major, minor, and trace elements; trace element distribution between inorganic and organic phases; hydrocarbon characterization; and adsorption/desorption studies of gas through shales.

Six cores (five from Illinois and one from western Kentucky) prövide the principal data base for these investigations. Four of these have been obtained through ERDA, the. other two from Survey files.

Using subsurface stratigraphic techniques, twenty-two cross-sections and a preliminary New Albany Group thickness map have been prepared. In addition, isopach maps are in preparation for each of the formations within the New Albany. Black shales predominate in the center of the Illinois Basin, whereas gray shales predominate around the margins of the Basin. A computer data base of over 5000 wells penetrating the New Albany Group has been compiled.

LANDSAT photo studies of western Illinois linears suggest that most of these linears are of glacial origin. Tectonic origins are not postulated for any of the linears, and caution is advised when interpreting linear features in glaciated terrains.

Mineralogic and petrographic studies have concentrated on two cores. A preliminary classification of four shales lithofacies based on primary depositional characteristics has been established and related to oxygenation of the bottom environment.

Preliminary results of physical index properties; major, minor, and trace elements; and gas compositions have been obtained for three cores. Internal surface area measurements reveal that gray shales have higher ultramicroporosily than do black shales. The gray shales also have high gas diffusion rates and are better reservoir rocks.
\end{abstract}




\section{Introduction}

In April 1976 the Illinois State Geological Survey proposed to conduct geologic and geochemical studies of the New Albany Group in Illinois to evaluate its potential for yielding hydrocarbons, particularly natural gas. The Survey will also perform chemical and physical analyses of shale samples from outside Illinois, submitted by other agencies participating in the United States Department of.Energy (DOE) (formerly Energy Research and Development Administration (ERDA)) research program on the Devonian gas shales of the eastern United States.

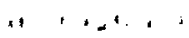

The ERDA sponsored program is leycd to the national goal of devel=. oping a greater self-sufficiency in energy resources in the United States in. the next ten years. Devonian shale formations in the Appalachian Basin, from eastern Tennessee to southern New York, have yielded significant quantities of natural gas. - In the Big Sandy gas field of southeastern Kentucky, more than 2 trillion cubic feet of gas has been produced from about 200 cubic miles of gas-bearing black shale. This is a production rate of about 1 cubic foot of gas per ton of shale, using the present method of well stimulation and production. Laboratory tests of the black shale show that by pyrolosis the yield of gas can be increased by as much as three orders of magnitude. Thus, the Devonian black shale of the Appalachian, Michigan, and Illinois Basins constitutes a vast potential reservoir of natural gas that might be utilized if suitable extraction techniques could be developed.

The Devonian black shale in the Appalachian Basin attains a maximum thickness of about 1500 feet in parts of Pennsylvanla. It also occurs in the Illinois basin, underlying the southern parts of Illinois and Indiana and the western part of Kentucky. In lllinois the black shale is called the New Albany Group (Devonian and Mississippian age) and attains a maximum thickness of about 400 feet.

The Illinols State Geological Survey has previously conducted studies of the energy-producing potential of the New Albany Shale. Several dark shales in the Illinois Basin have been analyzed to assess their potential as oil shales, and New Albany samples were included in these studies. A report by Lamar et al. (1956) presents the results of these analyses. The Devonian shales (New Albany and equivalents) yielded oll in amounts ranging from trace to 7 gallons per ton.

The New Albany was also studied to determine its potential as a petroleum source rock. This study measured the total organic carbon content of the shale and the benzene soluble hydrocarbon content. The results of this investigation were reported by Stevenson and Dickerson (1969). In the very dark-colored bottom 50 feet of the shale, organic carbon content ranges up to about 9 percent and averages about 4 percent. The New Albany Group is the most likely source rock for oil that presently occurs in reservolrs in the underlying Hunton Limestone Megagroup (Silurian-Devonian). The benzeneextractable compounds (both hydrocarbons and nonhydrocarbons) in the lower 
50 feet of the New Albany are estimated to be 100 times more than the total volume of oil found in the underlying Silurian-Devonian reservoirs. At the present time, however, no oil or gas is produced from the New Albany Shale in Illinois.

On the basis of the proven large volumes of natural gas in the Devonian black shale in the Appalachians and the indications of significant hydrocarbon content in the equivalent New Albany Group in Illinois, the Illinois State Geological Survey is conducting geological and geochemical investigations in Illinois to determine the character and magnitude of this potential resource.

are as follows:

The objectives of the work by the Illinois State Geological Survey

(1) To compile available drill-hole and outcrop data on the New Albany Group in Illinois. An important new source of data will be complete, oriented cores of the New Albany Group that will'be'obtäined through contractual drilling arranged by ERDA.

(2) To study the stratigraphy and structure of the New Albany Group, along with overlying and underlying rocks in Illinois, to determine relationships to occurrence of hydrocarbons, especiaily natural gas.

(3) To obtain selected data for comparison with geophysical logs to aid in broader and more rapid appraisal of the New Albany Group.

(4) To characterize in detail the New Albany Group in Illinois with respect to physical, mineralogical, and chemical properties and hydrocarbon content by detailed analyses of core materials, in order to delineate the most favorable targets for production of hydrocarbons under more sophisticated techniques of extraction.

(5) To encode all geologic and chemical data obtained in the investigation in a computer format designed for rapid retrieval and graphic presentation.

(6) To characterize chemically the Eastern Shales to aid in evaluating their economic importance, to aid in the exploration for natural gas, and to aid in an environmental assessment as a result of exploitation of this resource.

The individual projects are as follows:

GEOLOGIC

1. Stratigraphy and structure of New Albany in Illinois.

II. Mineralogic and petrographic characterization of New Albany in Illinois.

III. Analysis of physical properties of the Devonian black shale.

IV. Mineral resources evaluation systems (MINERS). 


\section{GEOCHEMICAL}

I. Quantitative determination of major, minor, and trace elements in eastern U.S. shales.

II. Trace element distribution between shale inorganic and organic phases.

III. Mode of occurrence and relative distribution of hydrocarbon phases in shale.

IV. Adsorption/desorption studies of gases through shales.

This report is organized into eight chapters which present the methods, results, and discussion of results for each individual project. A summary of significant observations and preliminary conclusions is presented at the end of the report. (References cited in this introduction are included with orrtinn TG.) 


\section{Sample numbering system}

A system of sample numbering devised at" the Illinois State Geological Survey for this project is used in this report. The sample number consists of 8 ciphers. The first 4 ciphers identify the core from which the sample was taken. The first two of these indicate the order of the core by state. The third and fourth are the abbreviations for the name of the state. The fifth and sixth ciphers of the sample number indicate the data set. Each 10-foot interval of the New Albany in the core is identified by a data set that is numbered in order starting at the top. The seventh cipher is a letter designating the main purpose for which the sample was taken and analyzed.

"L" stands for lithologic studies; "C" stands for chemical analyses of off-gases and constituent elements (sealed in canisters at the drilling site); "S" for sonic testing; " $T$ " for indirect tensile strength tests; and "P" for point load tests.

The last ciper in the number indicates the specific number of the sample-lithologic or chemical-taken from that data set interval of the core. In the case of lithologic samples, Ll samples are selected by a geologist during examination of the core to be representative of the predominant lithology in that data set, and L2, L3, etc. are taken of accessory 1 ithologies as needed. Thus, for example, the sample number 01IL02L2 identifies the second, or accessory lithologic sample taken from the second data set down into the New Albany from the OlIL core. In a fully computerized system, the first four ciphers can be keyed to the 9-digit API identification to identify the specific location of the core. 


\title{
IG. Stratigraphy and structure of New Albany in Illinois
}

\author{
Mark L. Reinbold, Jerry T. Wickham, David L. Stevenson, \\ Jerry A: Lineback, and John N. Keys \\ SCOPE AND PURPOSE
}

This project is a detailed analysis of the 1ithology, stratigraphy, and structure of the New Albany Group in Illinois to determine those characteristics of lithology, thickness, regional distribution, vertical and lateral variability, and deformation that are most relevant to the occurrence of hydrocalluins.

This study will result in the preparation of cross-sections, facies maps, and geologic structure maps based on subsurface data available in the Illinols Survey files." "Previous work in Illinois will be re-evaluated and updated. New data on the physical, chemical, and mineralogic characteristics of the New Albany will be derived from the studies of cores from new oil and gas industry holes in Illinois and will be incorporated into the stratigraphic and structural investigations of existing data.

\section{ACCOMPLISHMENTS}

(1) Bibliographies of 1iterature on New Albany Group and related topics for Illinois and adjacent states were completed (Milestone 1). (Milestone 2).

(2) Màp showiing LANDSAT 11near features in Illino1s was completed

(3) Twenty-two cross-sections. were prepared, using geophysical logs, core studies, and sample studies (Milestones 3-8).

(4) Preliminary total thickness map for New. Albany Group in Illinois was completed (Milestone 9).

(5) Data weregathered on a county basis for thickness maps of New Albany subunits. Data have been acquired for most of the southern half of the area underlain by New Albany in Illinois (Milestones 10-11). .

(6) A Bausch \& Lomb Zoom Transfer Scope, Model ZT4-H, for mapping of linear features, has been acquired and. used.

(7) Stratigraphic columns for core studies were prepared.

(8) Preparation was initiated of correlation charts for core studies; relating described lithology to geophysical-log characteristics, which will be followed by relating geophysical-log characteristics to physicaltests and geochemical studies. 
(9) Computer file of basic data on drill holes penetrating Upper Devonian shales in southeast quarter (Milestone 12) and southwest quarter (M1lestone 16) of Illinois was verified and completed.

(10) Above data were tabulated (M1lestones 13 and 17).

(11) Computer base map of Devonian tests for southeast (Milestone 14) and southwest (Milestone 18) quarters of Illinois was drawn.

(12) Maps of Devonian and Silurian oil and gas pools in Illinois were completed (Milestone 15).

\section{METHODS}

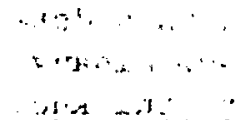

Cores were described in the field at the well location and subsequently described in greater detail in the laboratory when the core was being prepared for physical tests and sampling.

Stratigraphic studies were conducted using cores contracted for by ERDA, other cores in the files of the I111nols State Geological Survey, and sample studies and geophysical logs from Survey files.

Structural studies were begun, considering known structures in the Illinois Basin and studying lineations observed in LANDSAT imagery.

The computer file of basic data on drill holes penetrating the Devonian section was verified for accuracy and completeness by checking individual entrles for validity and by adding other qualified wells.

\section{RESULTS AND DISCUSSION}

Core summarles

Four cores from the New Albany Shale Group in. Illinois and one core from the New Albany Shale in Kentucky ( $f$ Ig $_{\text {. }} 1$ ) were studied in deta1l. Three of the Illinols cores and the Kentucky core were contracted for by ERDA and were taken during the past year specifically for. the ERDA Black Shale Project. The fourth Illinois core is from the Illinois State Geological Survey's core library.

The core contracted for by ERDA from Christian County, Kentucky (01KY, f18. 2a) was collected by the Geological Survey in September. 1976. The orlented core contains $145.6 \mathrm{ft}(44.4 \mathrm{~m})$ of New Albany Shale Group. The upper $76 \mathrm{ft}(23.2 \mathrm{~m})$. of the core $1 \mathrm{~s}$ brownish black, organic-rich Grassy Creek Shale. Beneath the Grassy creek Shale is $51 \mathrm{ft}(15.5 \mathrm{~m})$ of Sweetland Creek Shale and $19 \mathrm{ft}(5.7 \mathrm{~m})$ of black, calcareous Blocher Shale.

The Kentucky core provides data on the stratigraphy and characterization of the New Albany Shale in the southern parts of the Illinols Basin.

The Sangamon County.core (0IIL, $\mathrm{fig}_{\mathrm{g}} \cdot 3$ ) $1 \mathrm{~s}$ an nonorlenced 2-in. $(51 \mathrm{~mm})$ core completed in 1939. The core 18 important in that it has a falrly complete stratigraphy in the upper part of the New Albany Group. The 


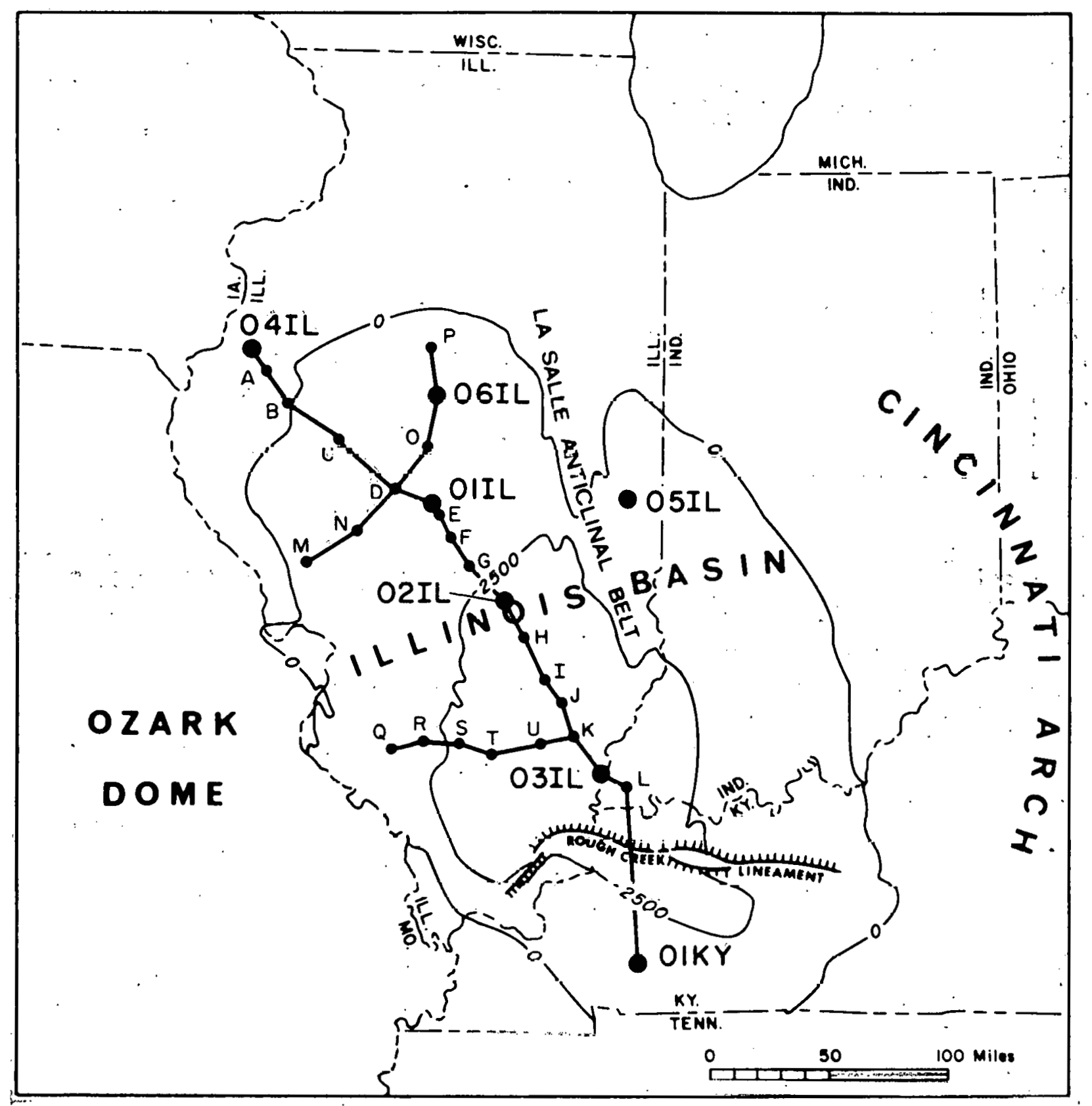

Fig. 1. Tectonic setting, locations of cores and wells used in cross sections. Contours show elevation (in feet) of the base of the New Albany Shale Group (after Swann and BC11, 1958, fly. 2). 


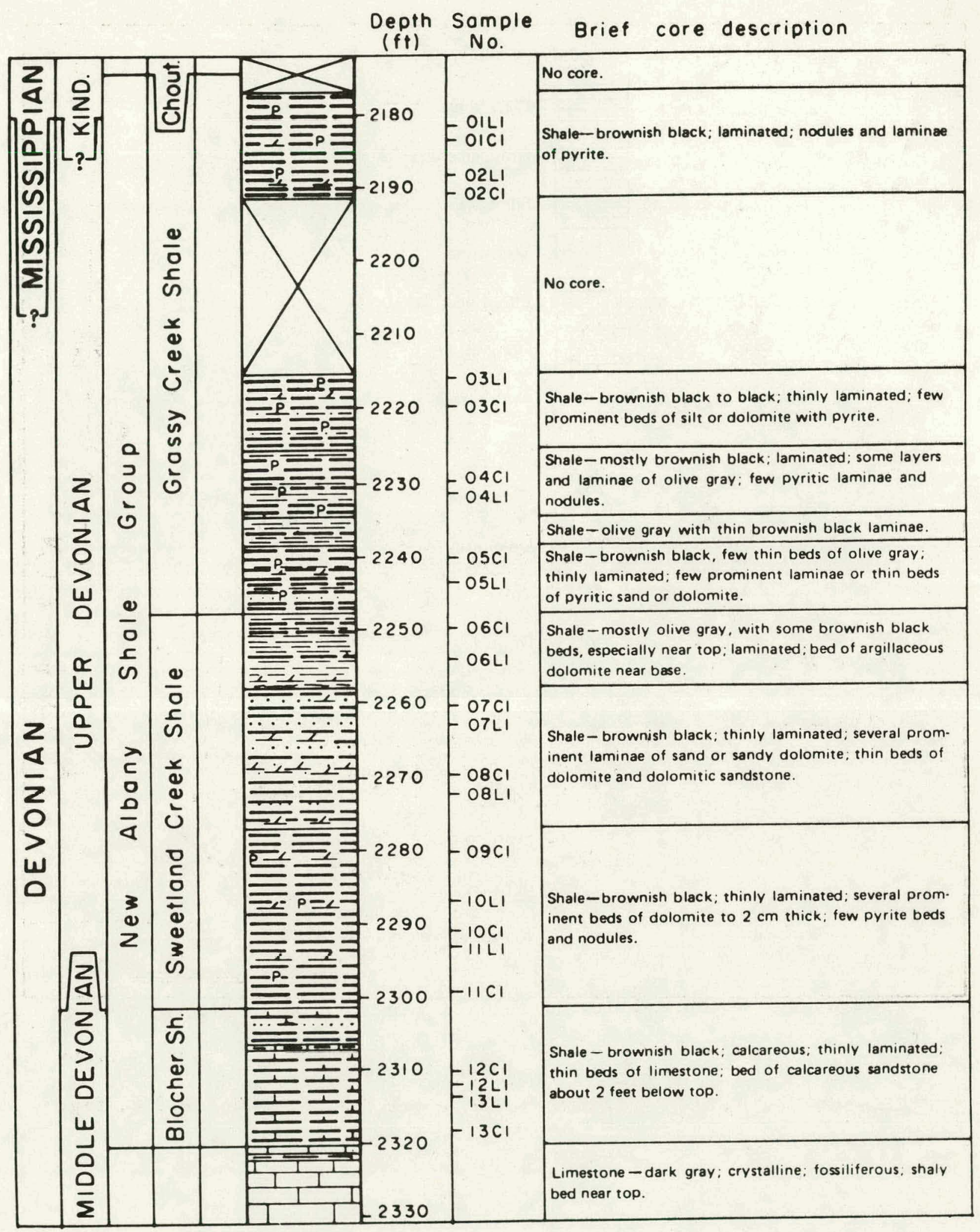

Fig. 2a. Stratigraphic section of Christian County, Kentucky, core (OIKY), approximate depths from which samples were taken, and generalized lithologic descriptions. 


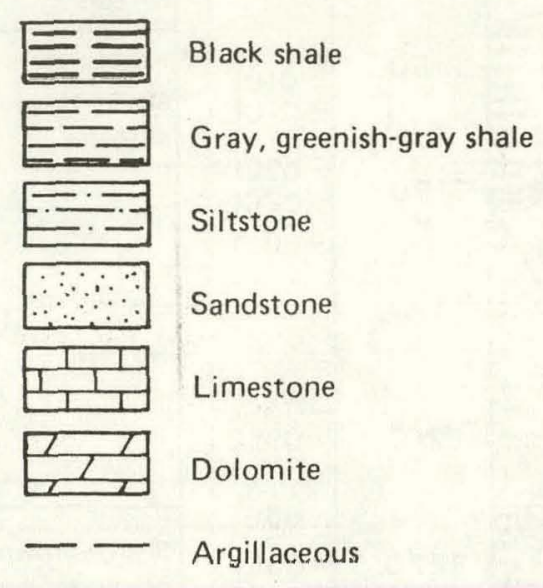

Silty

1 Calcareous

$\leftarrow$ Dulumitic

$\triangle \quad$ Cherty

Oolitic

* Vugs, Geodes

P Pyrite

S Spores

- Fossiliferous

\{ Burrows

$\sim \quad$ Wavy shale partings

Fig. 2b. Explanation of 1ithologic symbols used in figures 2 to 10. 


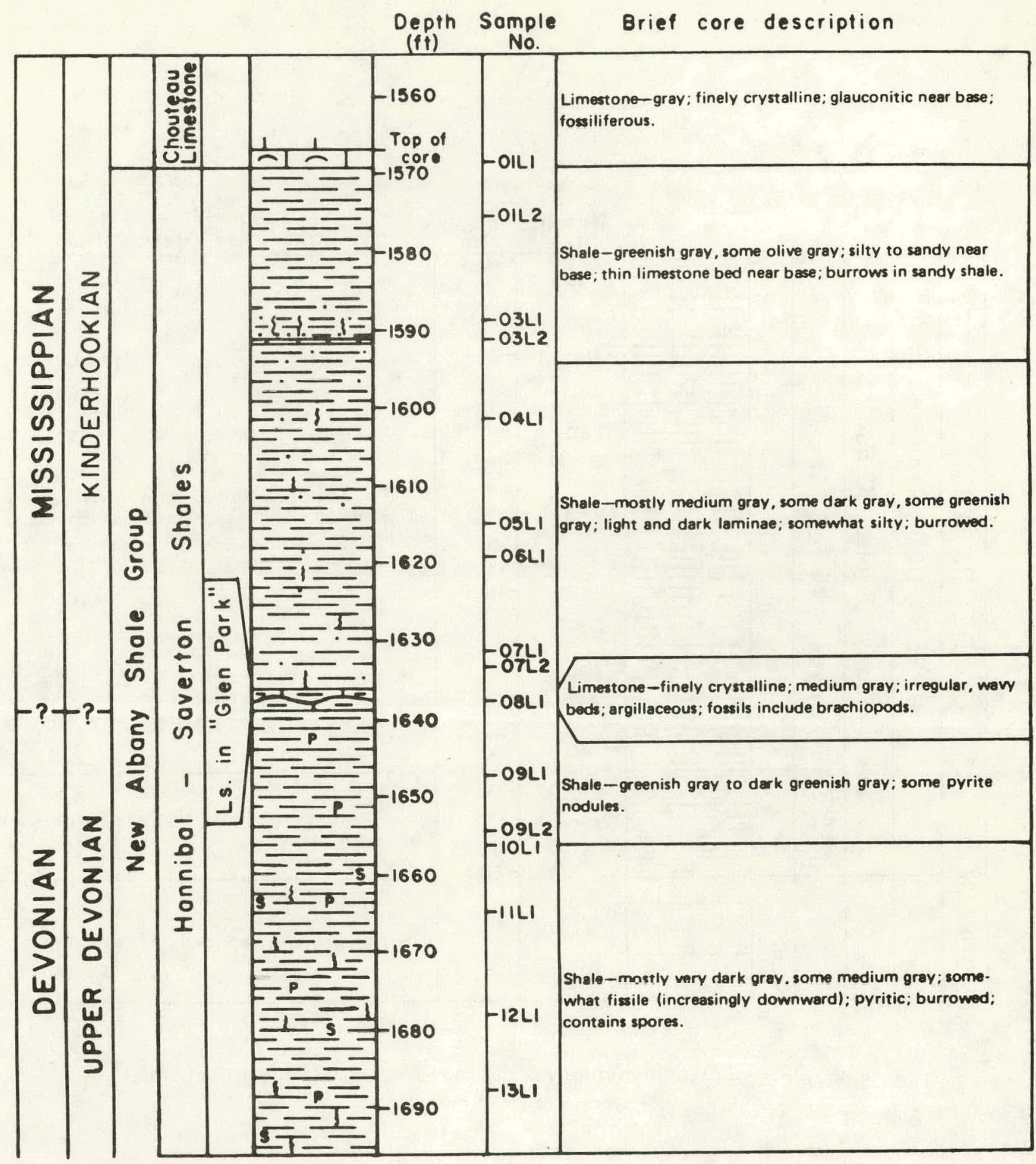

Fig. 3a. Stratigraphic section (upper portion) of Sangamon County, Illinois, core (01IL), approximate depths from which the samples were taken, and generalized lithologic descriptions. 


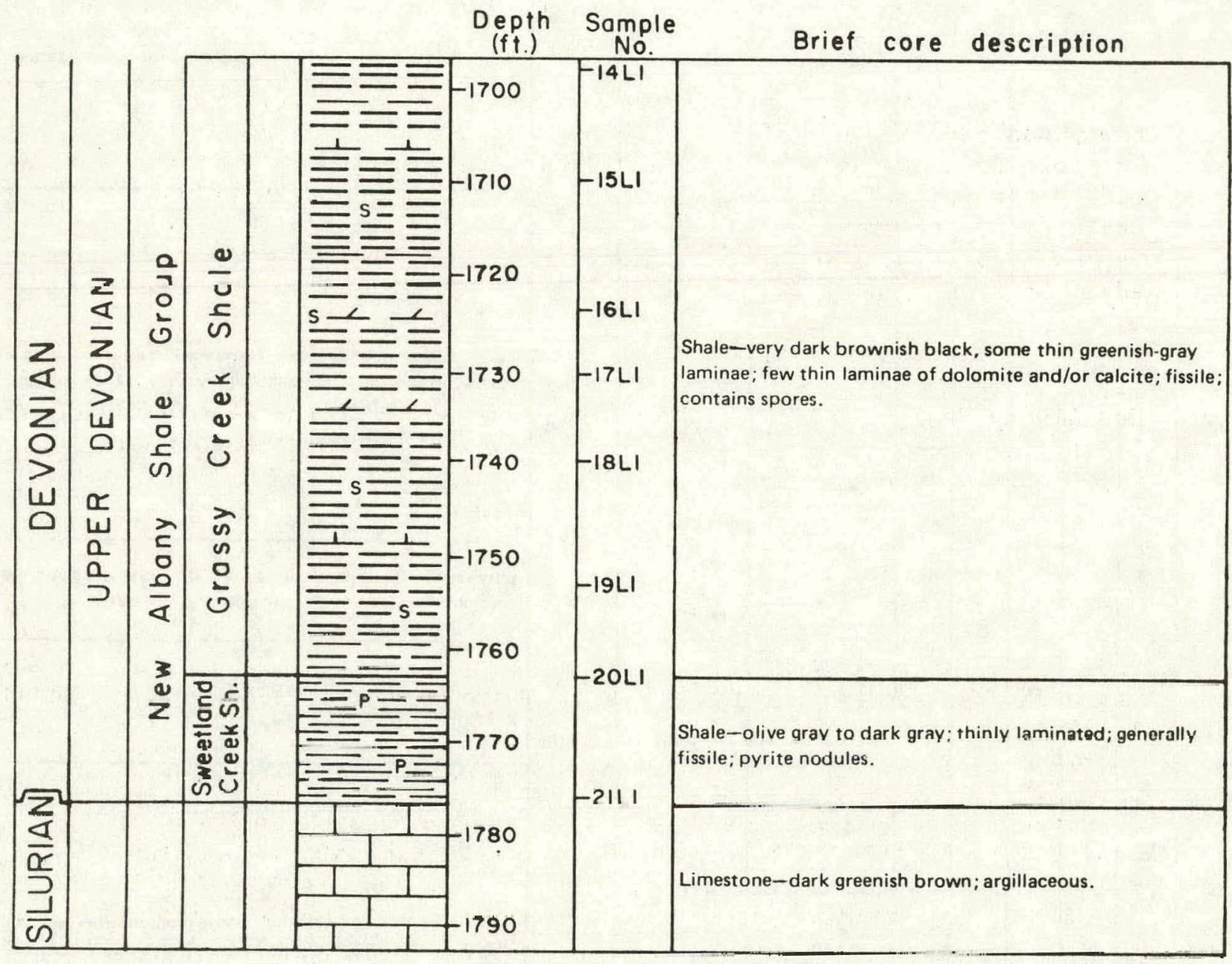

Fig. 3b. Sangamon County, Illinois, core (lower portion). 
core contains the Hannibal and Saverton Shales separated by a limestone layer. In areas of Illinois where the intervening limestone is absent, it is very difficult to differentiate the two shale units.

A second oriented core contracted for by ERDA was taken in Effingham County, Illinois (02IL, fig. 4), in a deeper portion of the Illinois Basin. The core contains $91 \mathrm{ft}(27.7 \mathrm{~m})$ of the New Albany Shale Group. In this core, the New Albany Shale is dominated by black shale lithologies which are characteristic of the New Albany in the deeper portions of the Illinois Basin.

In far western Illinois, $288 \mathrm{ft}(87.8 \mathrm{~m})$ of the New Albany Shale Group was recovered from a core in Henderson County, Illinois (04IL, fig. 5). The core contains $126 \mathrm{ft}(38.4 \mathrm{~m})$ of Hannibal-Saverton Shales overlying a combined thickness of $162 \mathrm{ft}(49.4 \mathrm{~m})$ of Grassy Creek and Sweetland Creek Shales. The presence of thick strata above the Grassy Creek Shale in this core is representative of the increase in greenish-gray shale lithologies toward the edges of the Illinois Basin.

The fourth core contracted for by ERDA was taken in Tazewe11 County, Illinois (06IL, fig. 6). This oriented core contains $221 \mathrm{ft}(67.4 \mathrm{~m})$ of the New Albany Shale Group. The lithology is similar to that of the Henderson County, Illinois, core with a thick interval of greenish-gray shale in the upper part of the core.

Preparation of cross-sections and maps from subsurface data

To date, twenty-two stratigraphic cross-sections of the New Albany Shale Group have been prepared from subsurface data files of the Illinois State Geological Survey. These sections span the entire length and breadth of Illinois where the New Albany occurs in the subsurface and are linked to crosssections in Indiana and western Kentucky. These cross-sections are compiled primarily from geophysical log data, but are supplemented with sample studies of rotary-drill cuttings, especially where geophysical data are sparse. In addition, core studies have been utilized wherever possible. These include the cores contracted for by ERDA, as well as others from Survey files. The cross-sections are used to determine the lateral extent of 1ithologic units, to define lithofacies and facies boundaries, and to provide data for isopach and facies maps.

Three cross-sections have been specially prepared for illustration in this report (figs. 7, 8, 9). These sections have been located so as to link the wells cored for ERDA, as well as to show lithologic variation along traverses which are essentially parallel or perpendicular to the long axis of the Illinois Basin.

Additional data from numerous holes are being examined to determine correlations with holes of nearby cross-sections and to provide data for isopach and facies maps. To date, this intensive data-gathering has been restricted principally to the southern half of the area underlain by New Albany in Illinois. Isopach maps are in preparation for the New Albany Group, as well as for each of its component formations and for the overlying Chouteau Limestone. A preliminary isopach map of the New Albany Group (fig. 10) has been completed, using data from wells in the cross-sections. The data will 


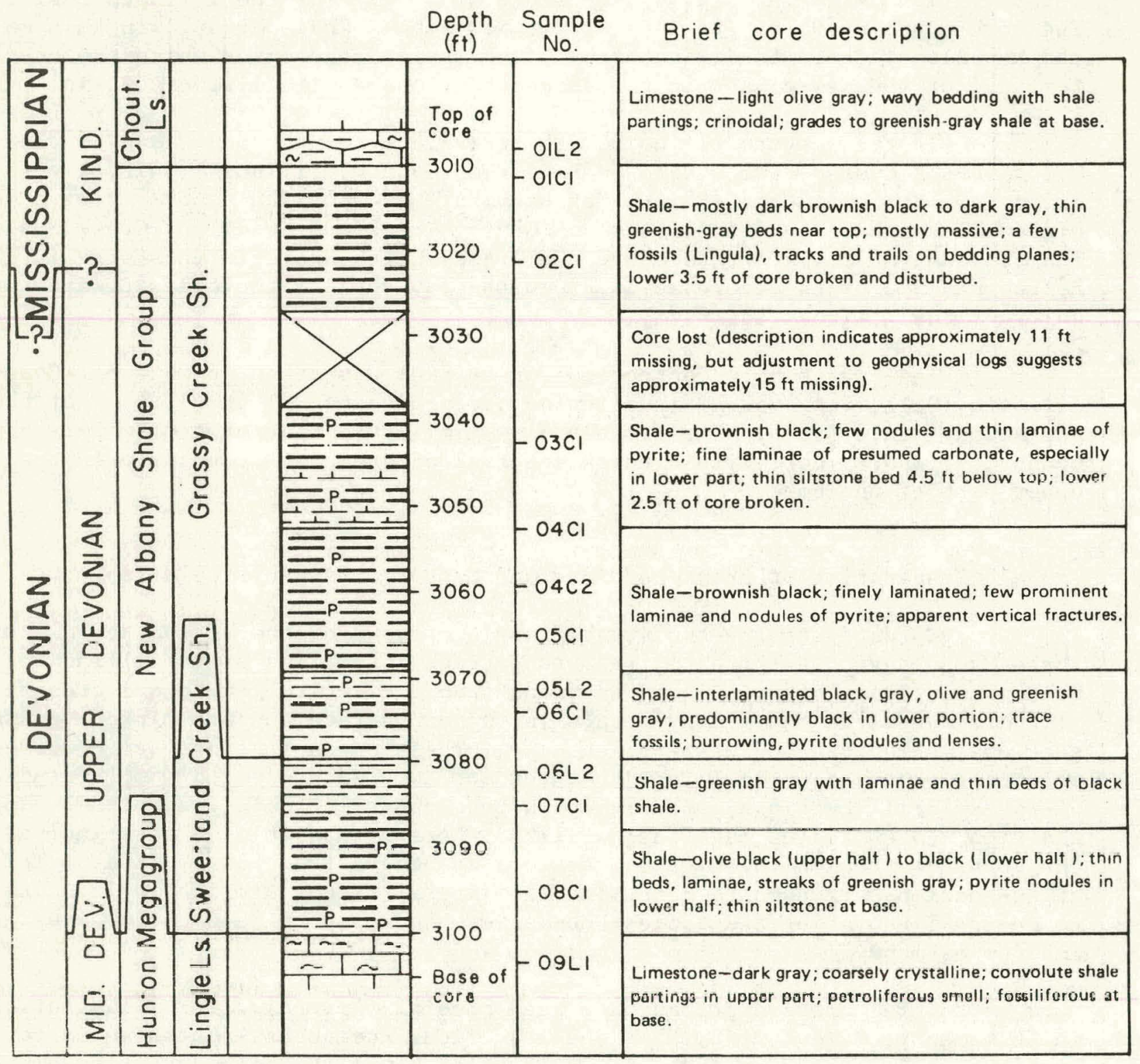

Fig. 4. Stratigraphic section of Effingham County, Illinois, core (02IL), approximate depths from which samples were taken, and generalized lithologic descriptions. 


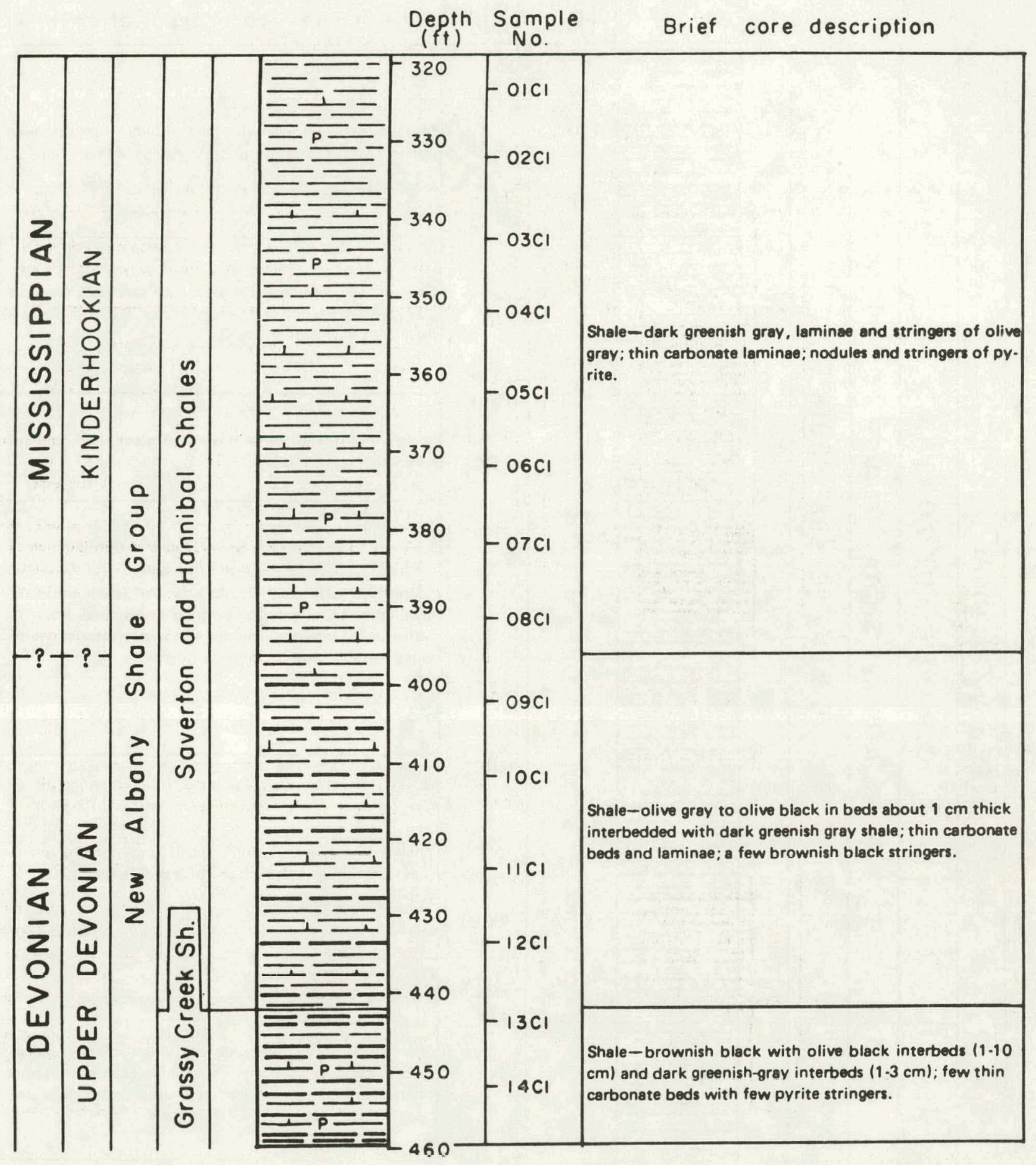

Fig. 5a. Stratigraphic section (upper portion) of Henderson County, Illinois, core (04IL), approximate depths from which samples were taken, and generalized lithologic descriptions. 


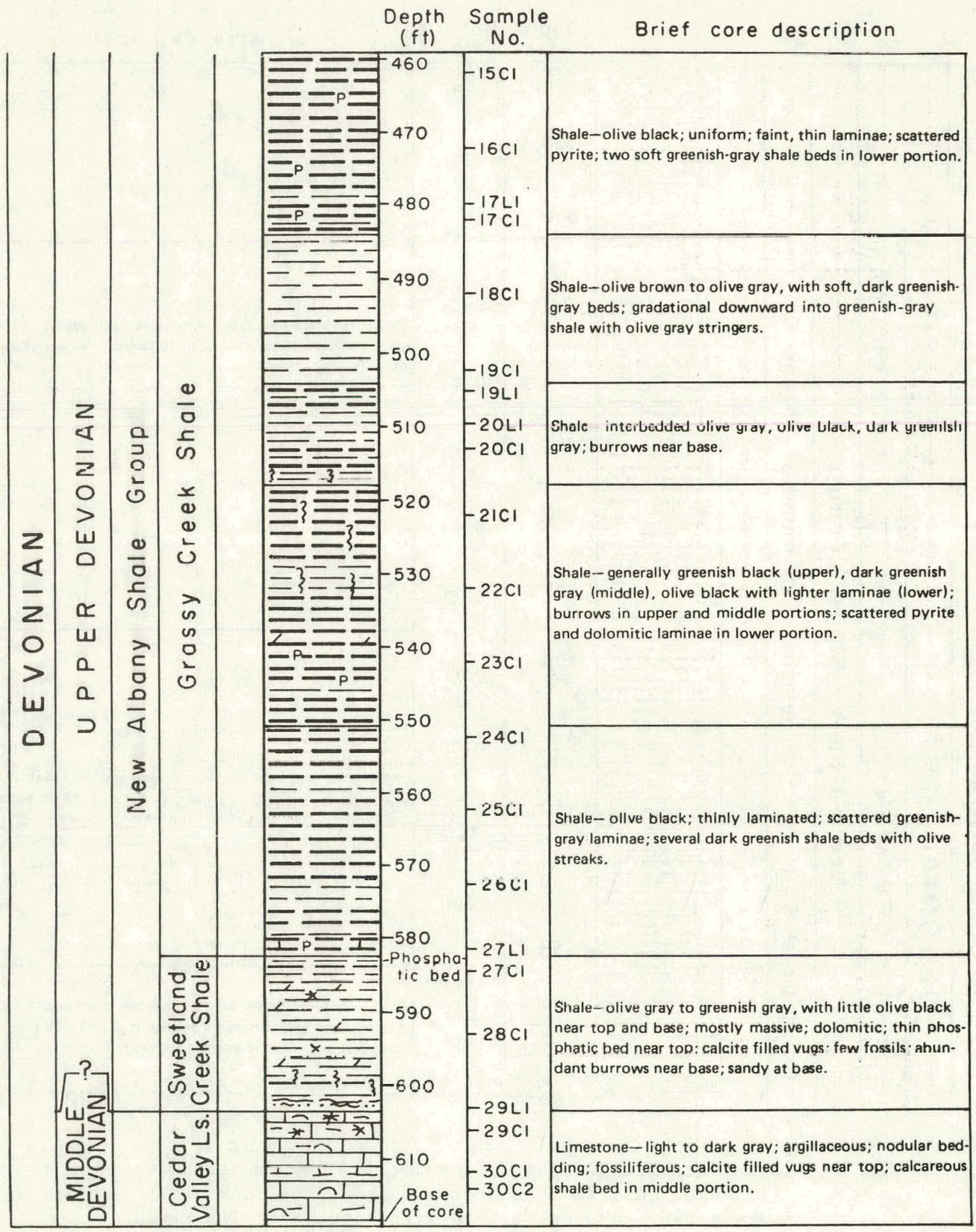

Fig. 5b. Henderson County, Illinois, core (lower portion). 


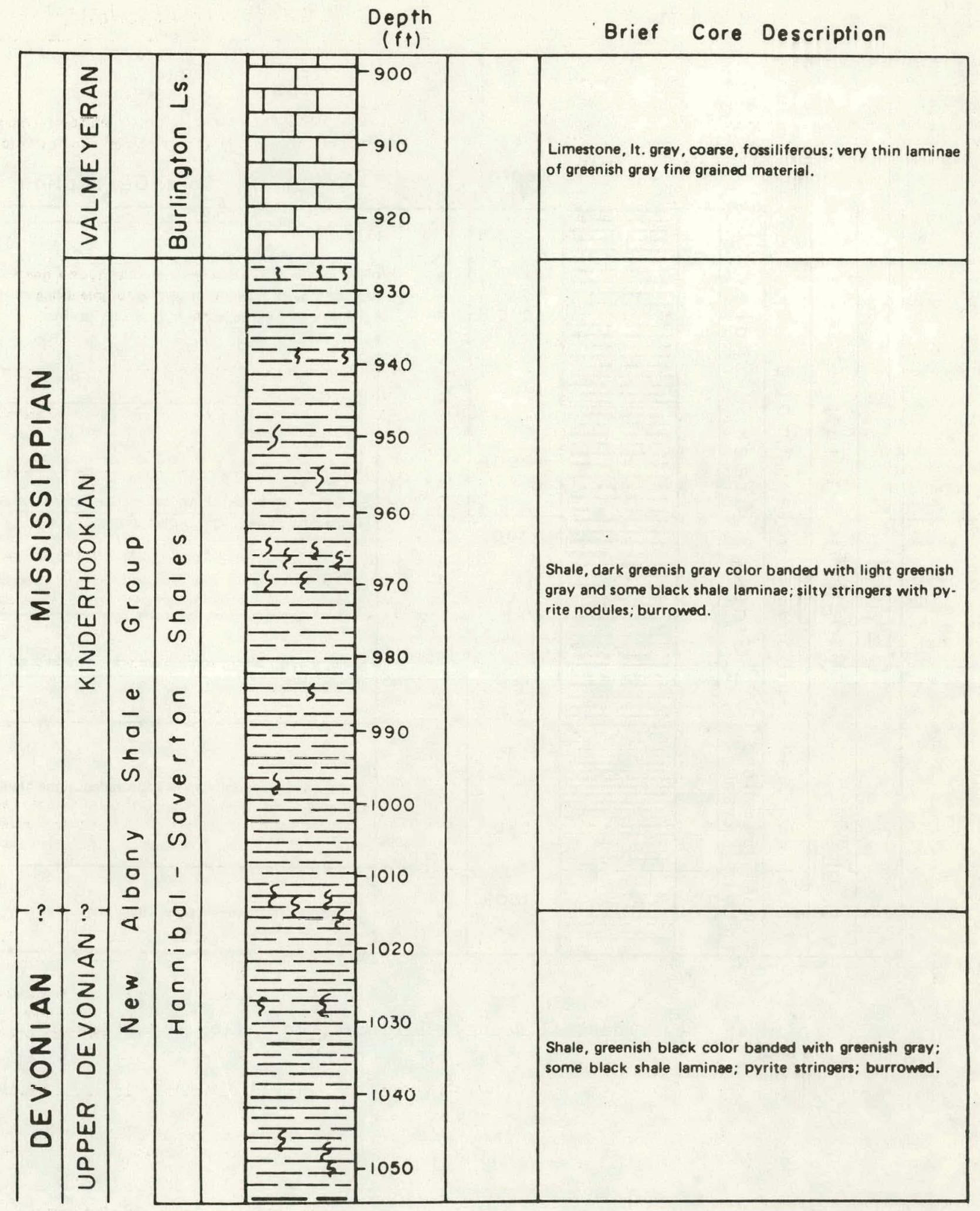

Fig. 6a. Stratigraphic section of Tazewell County, Illinois, core (06IL) and generalized lithologic descriptions. Sample numbers not yet available. 


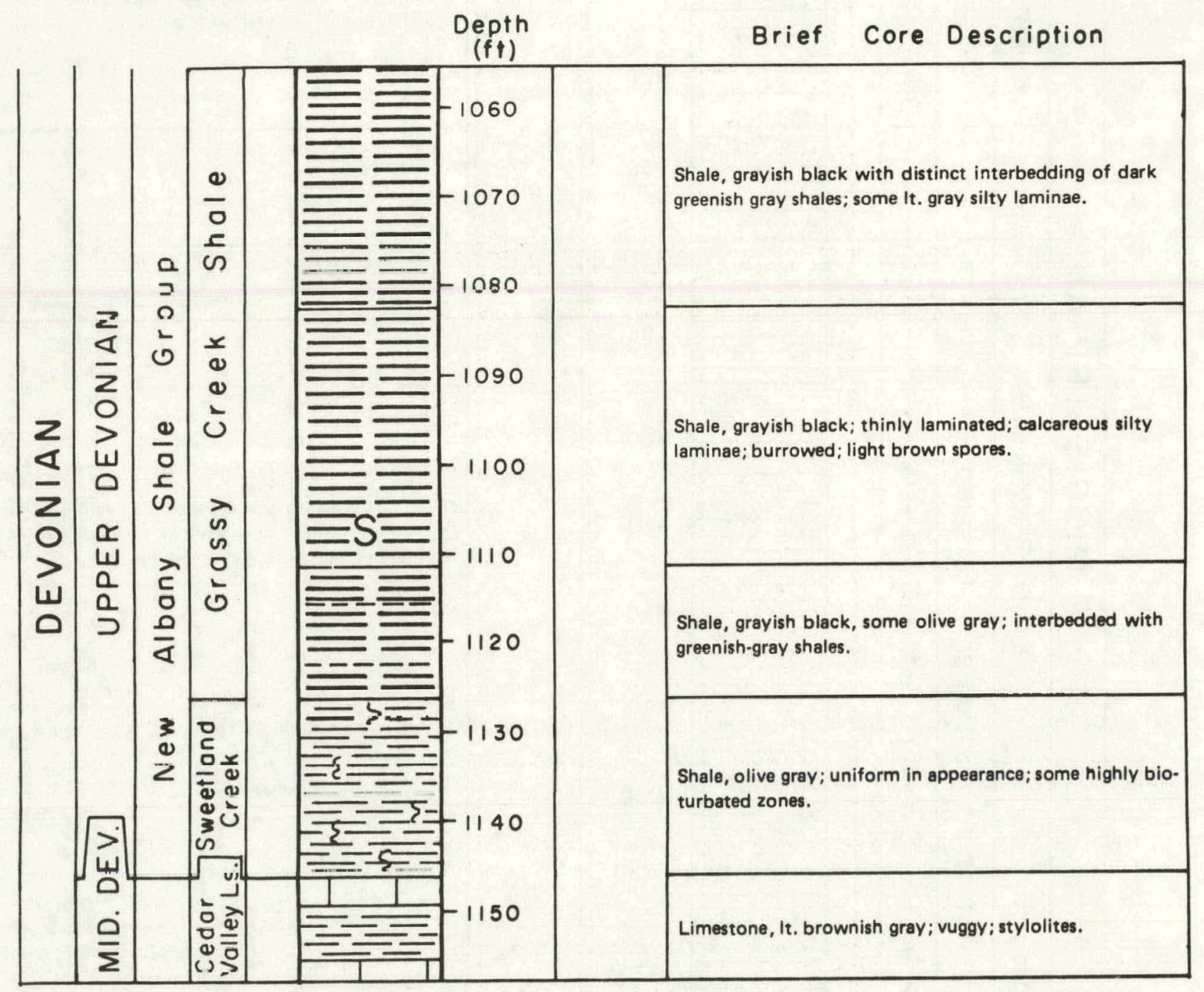

Fig. 6b. Tazewe11 County, Illinois, core (lower portion). 


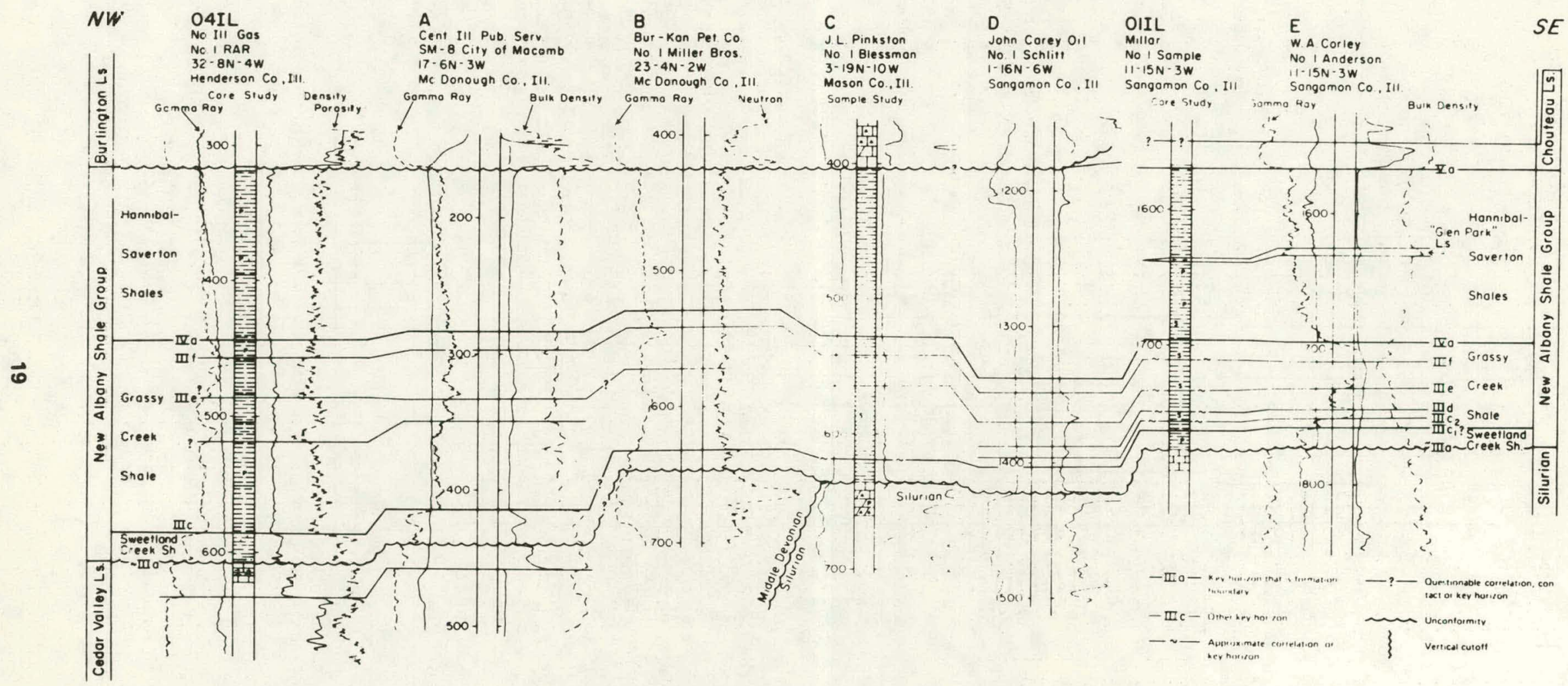

Fig. 7a. Northwest-southeast cross-section 04IL-E, using geophysical logs, core studies, and sample study. 


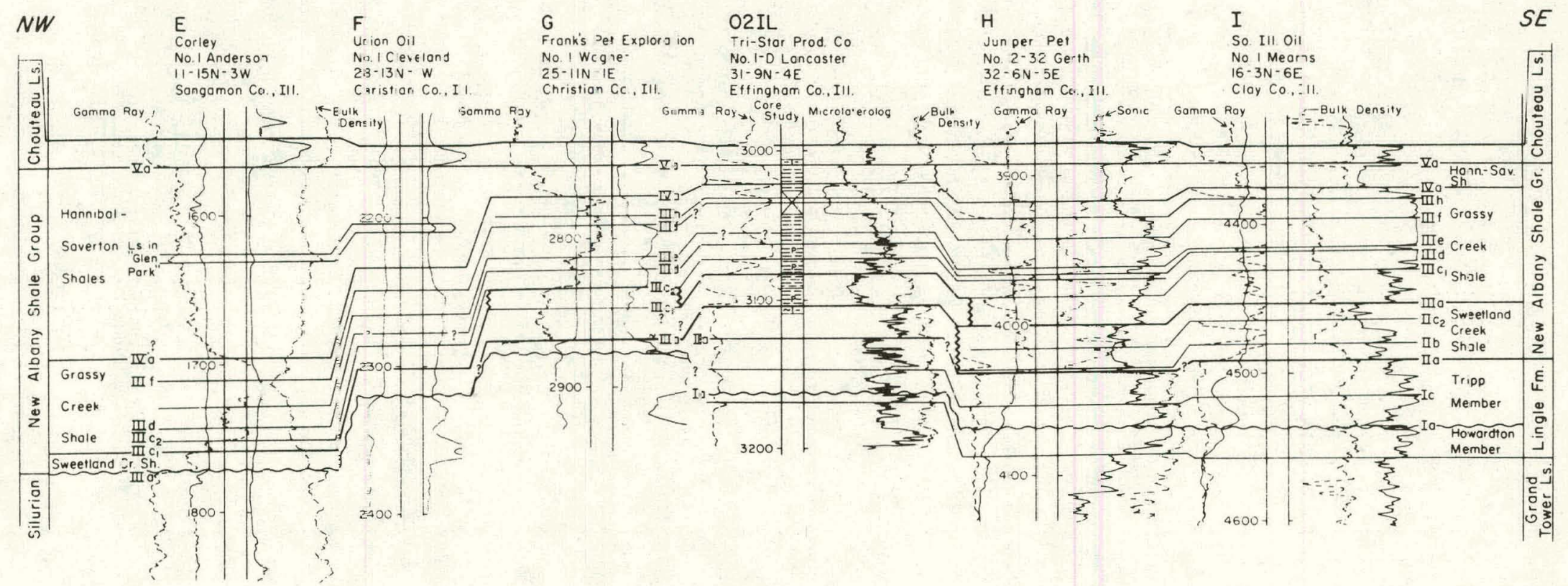

Fig. ?b. Northwest-southeast cross-section E-I, using geophysical logs and core study. 


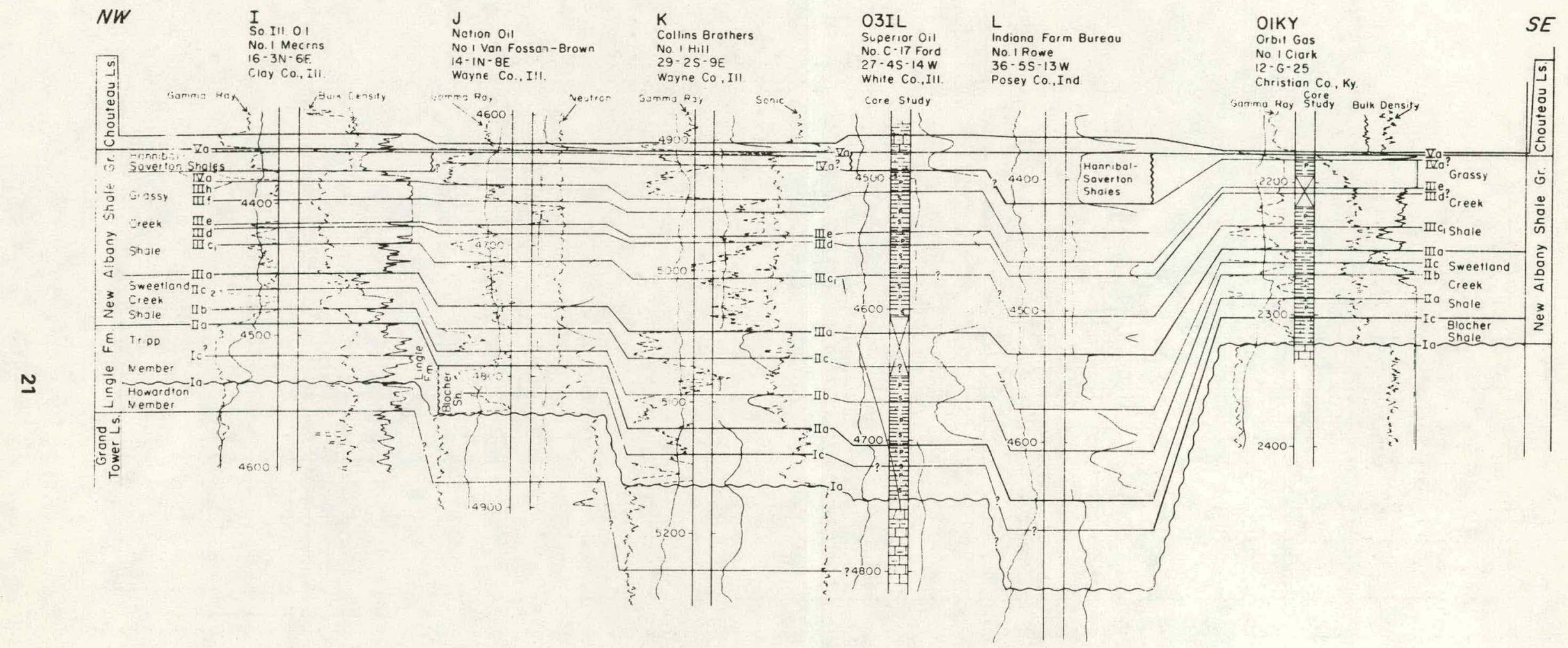

Fig. 7c. Northwest-southeast cross-section I-01KY, using geophysical logs and core studies. 


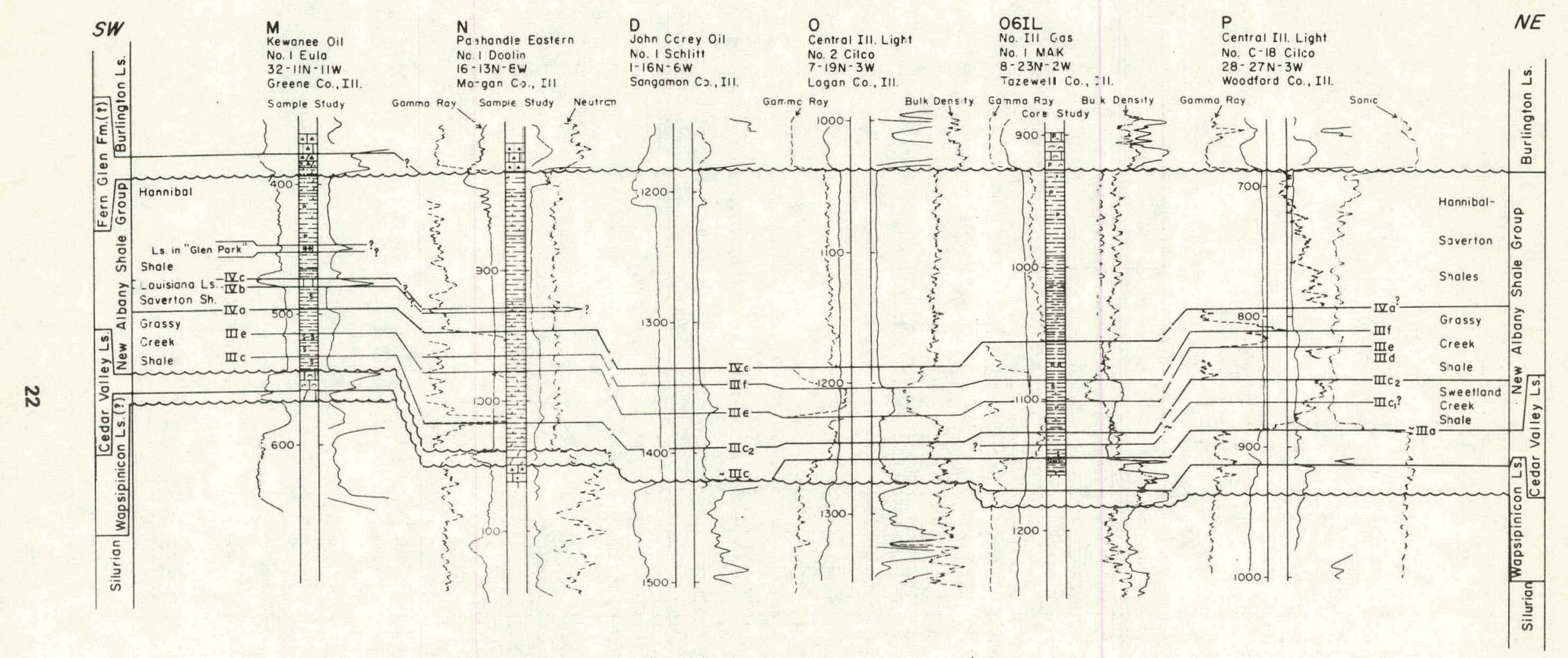

F-g. 8. Southwes=-northeast cross-section M-P, using geophysical logs, core stuly, and sample studies. 


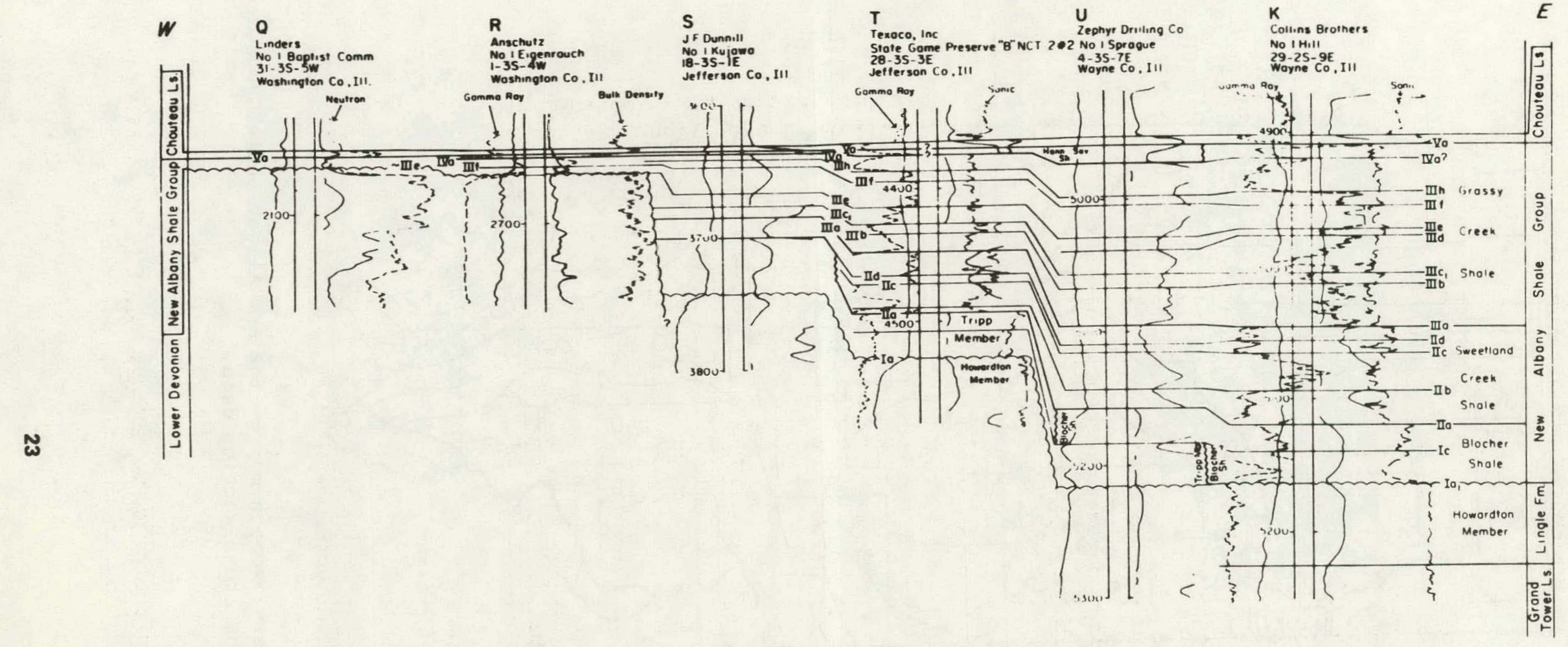

Fig. 9. West-east cross-section Q-K, using geophysical logs. 


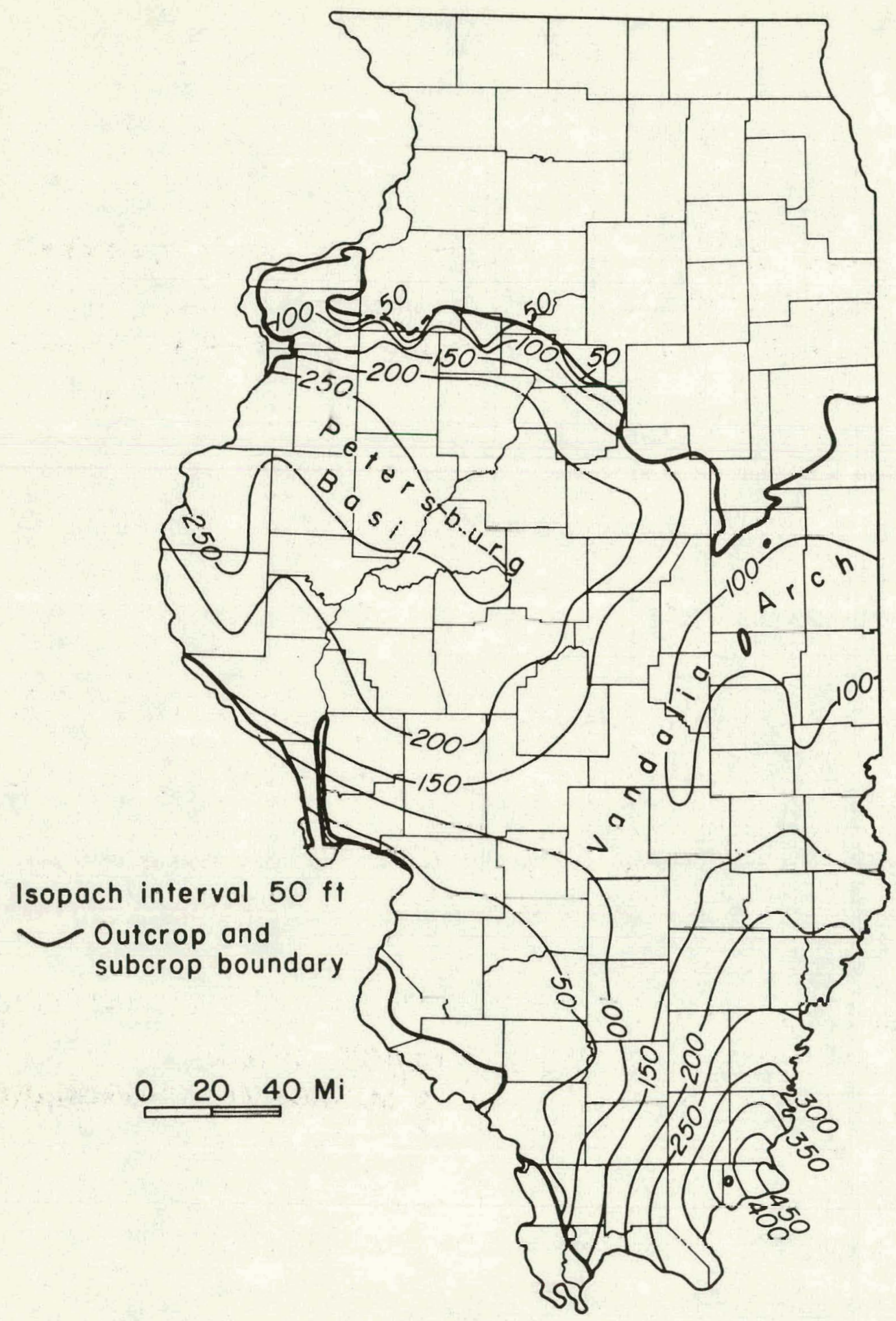

Fig. 10. Preliminary isopach map of the New Albany Shale Group, compiled from cross-section data. 
also be analyzed to prepare maps of facies, depositional environments, and relationships of the New Albany Group to underlying and overlying rocks.

Potential data points for this study, particularly geophysical logs, are most densely distributed in central and southern Illinois. In these parts of the state, where possible, we use at least one data point per township. In the northern and western portions of the area underlain by New Albany, data, particularly geophysical logs, are generally much more sparsely distributed, and such spacing of map data points is not possible.

Because of their relative abundance, electric logs are our most important source of data. Other geophysical logs-particularly gamma ray (natural radioactivity), sonic velocity, and density logs, and, to a lesser extent neutron logs-are used, when available, in conjunction with the electric logs.

\section{Geophysical characterization of lithologic types}

Since geophysical logs are our primary data sources, it is necessary to relate geophysical properties to lithologies. This is done by way of direct comparison of geophysical logs to corresponding descriptions of the more numerous, but less reliable, sample studies.

The New Albany Shale Group and stratigraphically adjacent rocks can be classed into five main lithologic types, but there are among these, of course, gradational lithologies. These lithologies can be distinguished with a high degree of reliability on the basis of their geophysical characteristics (see figs. 7 and 8 , wells 04IL, C, 01IL, E, 02IL, 03IL, 01KY, M, N, 06IL). These lithologies are categorized as follows.

(1) Black or brownish black shale. Moderate to very high (generally high) electrical resistivity; variable spontaneous potential (SP) (generally negative); generally high to very high gamma ray (natural radioactivity) count; generally low neutron (induced radioactivity) reading; low density; low sonic velocity.

(2) Greenish-gray to gray shale. Generally low resistivity; variable SP (generally positive); moderate gamma ray count; low to moderate neutron reading; moderate to moderately high density; moderate to moderately high sonic velocity.

(3) Calcareous or dolomitic shale. Moderate to high resistivity; SP generally more negative than previously described shales; low to moderate gamma ray count; moderate to high neutron reading; moderate to moderately high density; moderate to moderately high sonic velocity.

(4) Limestone. Moderate to very high (generally high) resistivity; SP variable, but generally more negative than shales; low to very low gamma ray count; generally high neutron reading; high density; high sonic velocity.

(5) Siltstone. Low to moderate resistivity; SP generally more negative than shales, more positive than limestone; low to moderate gamma ray value; moderate to moderately high neutron reading; moderate to moderately high density; moderate to moderately high sonic velocity. 
Stratigraphic correlation

In this study, stratigraphic units are correlated primarily through the recognition of key horizons on geophysical logs. These horizons, which appear as surfaces of discontinuity in geophysical properties, are inferred to represent significant lithologic contacts. Boundaries of formations and other stratigraphic units are defined in terms of significant lithologic changes.

An informal numerical system has been used in this study to identify several laterally traceable geophysical horizons within the New Albany Shale Group and adjacent strata. This numbering system is used in the cross-sections (figs. 7,8 and 9).

These geophysical horizons are defined principally in terms of discontinuities in electrical resistivity, gamma ray, and sonic velocity values. Generally, major lithologic changes are reflected by sharp discontinulties in these and other geophysical properties at very nearly the same levels.

The No. 1 Hill well in Wayne County, Illinois, (fig 7c, well $\mathrm{K}$; fig. 9, well K) has been utilized in this study as a main subsurface reference section for the purpose of defining geophysical horizons in the lower part of the New Albany shale Group. In this well, horizons Ia, IIa, and IIIa are sharp geophysical discontinuities which represent the bases of the Blocher, Sweetland Creek, and Grassy Creek Shales, respectively. The IVa horizon is the presumed base of the Saverton Shale in western Illinois (see fig. 8, wells $M, N)$. The Va horizon is generally the base of the Chouteau Limestone.

Additional horizons such as IIb, IIc, etc., represent other fairly abrupt changes in one or more geophysical properties, but they are not of sufficient magnitude to be considered formational boundaries in the reference sections. Many of these horizons are widely traceable, and in some areas they may become discontinuities of greater magnitude, than, for instance, the IIa. horizon.

In some areas, two or more closely spaced horizons may define smaller-scale interbedding or gradational changes from one bulk lithology to another. However, in other places, these subhorizons may not be readily dis tinguished from one another. Hence, in some areas, subhorizons such as IIIc 1 and III $c_{2}$ may be distinguished, whereas elsewhere, only a single $111 \mathrm{c}$ horizon is discernible (figs. 7 and 8 ).

Formal stratigraphic nomenclature

The New Albany Shale, which was originally designated as a formation, is named for New Albany, Floyd County, Indiana (Borden, 1874). The New Albany Shale is now given group status in Illinois (Collinson and Atherton, 1975). Through the years, several schemes of classification have been used in subdividing the Middle Devonian to Kinderhookian (lower Mississippian) shales and related strata which comprise the New Albany Shale Group. However, for the purposes of the Illinois Basin study, the Indiana and Kentucky Geological Surveys have tentatively agreed to use the stratigraphic nomenclature currently accepted by the Illinois State Geological Survey. These formational units, from bottom to top, are described lithologically and characterized geophysically as follows. 


\section{Blocher Shale}

The Blocher Shale (Campbell, 1946; Lineback, 1968) is named for Blocher, Scott County, Indiana. Its occurrence in Illinois is restricted to the southeastern portion of the state. Farther to the north and west, the shale grades laterally into the upper portion of the Middle Devonian Iingle Limestone (North, 1969). In southeastern Illinois the Blocher consists of dark brown to black shale, which is mostly calcareous or dolomitic, especially in the upper part. The high carbonate content, reflected by relatively high resistivity and low gamma ray count, serves to distinguish the Blocher from the overlying Sweetland Creek Shale.

\section{Sylamore Sandstone}

The Sylamore Sandstone (Penrose, 1891), which is the basal Upper Devonian formation in parts of central and western Illinois (Workman and Gillette, 1956), is named for Sylamore Creek, Stone County, Arkansas. The sandstone occurs widely in the northern and western portions of the Illinois Basin. It is rarely more than a few feet thick, is more commonly only a few inches, and may be only a thin, sandy layer in the base of the Sweetland Creek or Grassy Creek Shales (Collinson and Atherton, 1975). Furthermore, even where present, the Sylamore is difficult or impossible to distinguish on geophysical logs. For these reasons, the Sylamore has not been designated a separate map unit for purposes of this study.

\section{Sweetland Creek Shale}

The Sweetland Creek Shale (Udden, 1899) is named for Sweetland Creek, Muscatine County, Iowa, and as originally described, it included all the Devonian shale at that locality. Collinson et al. (1967) restricted the Sweetland Creek to the dominantly gray and green shale, which underlies the predominantly black Grassy Creek Shale and extends throughout much of the Illinois Basin (Collinson, 1961; North, 1969). In southeastern Illinois, the Sweetland Creek contains much dark gray to black shale, but it can be distinguished geophysically from the Grassy Creek, which generally exhibits substantially higher resistivity and gamma ray values than does the Sweetland Creek.

\section{Grassy Creek Shale}

The Grassy Creek Shale (Keyes, 1898, 1912; Collinson et a1., 1967) is named for Grassy Creek, Pike County, Missouri. The formation, as defined by Collinson et a1. (1967), is dominant1y brownish-black to black, organicrich shale, which can be recognized on geophysical logs, particularly by its high resistivity and gamma ray values. However, in some areas, particularly those far to the north or west of the center of the Illinois Basin, the Grassy Creek also contains substantial interbedded greenish-gray shale. Furthermore, in these areas, the black shale generally shows somewhat lower resistivity and gamma ray values than it does near the center of the basin. In northern and in parls of central Illinols, the Grassy Creek is very difficult to distinguish from the underlying Sweetland Creek Shale. 


\section{Saverton Shale}

The Saverton Shale (Keyes, 1912), a gray to greenish-gray shale, is named for Saverton, Ralls County, Missouri. The Saverton is distinguished geophysically from the Grassy Creek by its generally much lower resistivity and gamma ray values. However, the Saverton is quite similar to the Hannibal Shale, which overlies it where neither the Louisiana Limestone nor the "Glen Park" Formation is present. For purposes of this study, where the Louisiana and "Glen Park" are absent, the Hannibal and Saverton Shales are treated as Hannibal-Saverton Shales undifferentiated.

\section{Louisiana Limestone}

The Loulstana Llmestone (Keyes, 1892), named for Loulsiana, Pike County, Missouri, is a light gray to buff, fine-grained, fossiliferous limestone. In Illinois, the lateral extent of the formation is limited to a small area in the west-central portion of the state. The Louisiana Limestone is characterized geophysically by moderate to high resistivity, low gamma ray value, and negative SP.

\section{"Glen Park" Formation}

In west-central Illinois the Louisiana Limestone is disconformably overlain by the "Glen Park" Formation. According to Collinson and Atherton (1975), the "Glen Park" in Illinois is not correlative to the type Glen Park Formation of Missouri (Ulrich, 1904; Moore, 1928); therefore, they recommend adoption of a new name for the Illinois strata. The "Glen Park" Formation, which is restricted to west-central Illinois, consists of silty shale, siltstone, sandstone, and limestone. A thin limestone, which is oolitic at many localities and is widely traceable in west-central Illinois, is referred to in this study as a limestone in the "Glen Park." The "Glen Park" grades laterally into the lower portion of the Hannibal Shale.

\section{Hanniba1 Shale}

The Hannibal Shale (Keyes, 1892) is named for Hannibal, Marion County, Missouri. The formation consists primarily of shale which is greenish gray, silty, and partly calcareous. In some areas it also contains some black shale beds, particularily in the upper part.

Workman and Gillette (1956) considered the Hannibal Shale a group, and in western Illinois, they subdivided it into the Glen Park (Ulrich, 1904), Maple Mill (Bain, 1895), and English River (Bain, 1895) Formations. Atherton et al. (1975) consider the Hannibal Shale a formation (within the New Albany Group) overlying the "Glen Park" Formation.

In this study, in areas where the underlying "Glen Park" Formation and Louisiana Limestone are absent, the Hannibal and Saverton Shales cannot be separately distinguished, and they are mapped as the Hannibal-Saverton Shales (undifferentiated). 
In general, the Hannibal Shale exhibits low to moderate resistivity and moderate gamma ray values.

\section{Formations defined in terms of facies}

The formational units within the New Albany Shale Group have been defined in terms of dominant lithologies. However, the major lithologic types within the New Albany demonstrate considerable large- and sma11-scale interbedding, lateral intertonguing, and gradational changes, both lateral and vertical, from one lithology to another. Because of these facies relationships, major bulk lithologic changes (as inferred from geophysical discontinuities) do not always continue laterally at the same geophysical horizons, which are considered to be essentially bedding planes. For example, near the center of the basin in southeastern Illinois, the IIIa horizon separates the dominantly black Grassy Creek Shale from the largely gray Sweetland Creek Shale. However, farther to the northwest, the change from predominantly gray to black shales is displaced stratigraphically upward to the IIIc horizon (fig. 8). This demonstrates that in part the Sweetland Creek and Grassy Creek Shales grade laterally into one another. For this and similar cases, we employ the concept of arbitrary vertical cutoffs, lines along which a part of one formation grades laterally into a different formation. In dealing with stratigraphic sequences of this type, it is clear that a formation is most conveniently defined in terms of a dominant facies (as reflected in dominant lithology) rather than as the stratigraphic interval between two laterally persistent bedding planes.

\section{Stratigraphic relationships of New Albany Group to underlying and overlying strata}

In most of the Illinois Basin, the New Albany Shale Group overlies Middle Devonian Limestones of the Hunton Megagroup. In southern and eastern Illinois, this contact appears generally conformable, and according to North (1969) the Blocher Shale and, where the Blocher is absent, the lower part of the Sweetland Creek Shale, grade laterally into the upper part of the Lingle Limestone, indicating a facies relationship between the shales and the carbonates.

In much of the northwestern area of the New Albany in Illinois, the group overlies the Middle Devonian (to lowermost Upper Devonian) Cedar Valley Limestone. The erosional contact indicates a minor unconformity, but fossil evidence suggests a relatively brief hiatus (Collinson and Atherton, 1975).

In west-central Illinois, on the ancient Sangamon Arch (Whiting and Stevenson, 1965), the New Albainy unconformably overlies large areas of Silurian strata (predominantly carbonates) and one small area of Ordovician strata (Workman and Gillette, 1956). In suuthwestern Illinois, on the flank of the Ozark Uplift, the New Albany unconformably overlies Ordovician, Silurian, and Lower Devonian strata (Workman and Gillette, 1956).

Throughout most of its area of occurrence in I11inois, the New Albany Group is overlain by Mississippian (Kinderhookian to Valmeyeran) strata. However, in the north, it is erosionally truncated by Pennsylvalian strata, and In a emall ared in extreme southern IIlinois by Cretaceous strata (Collinson and Atherton, 1975). 
In most of southern and eastern Illinois, the Hannibal Shale or its equivalents are overlain conformably by the Chouteau Limestone (Kinderhookian). The Chouteau appears to intergrade laterally with the upper part of the Hannibal.

In an area in east-central Illinois, the Hannibal is overiain by the Borden Siltstone (Valmeyeran), and in two areas in southeastern and extreme southern Illinois, it is overlain by the Borden's facies equivalent, the Springville Shale. Workman and Gillette (1956) seem to suggest that in the two more northerly of these areas, post-Kinderhookian uplift and erosion removed the upper portions of the Kinderhookian strata (including possibly the Chouteau Limestone). However, isopach trends, which indicate a gradual thinning toward these areas (T. C. Buschbach, personal comm.), and geophysicallog evidence from southeastern Illinois suggest a depositional pinchout of the Chouteau next to these apparently positive areas. Hannibal Shale deposition may, therefore, have continued essential1.y without interruption into Springville shale deposlliull.

In extreme western Illinois, the Hannibal Shale is conformably overlain by the McCraney Limestone, which laterally intergrades with the Hannibal, and is equivalent to the luwer part of the Choutcau (Atherton et al., 1975).

Elsewhere in most of the northwestern portion of the area underlain by the New Albany, the New Albany, as well as the Chouteau and equivalents, are truncated and unconformably overlain by Valmeyeran strata (Atherton et al., 1975). In portions of this area, the basal Valmeyeran is the Meppen Limestone or Fern Glen Formation, but over most of the area it is the Burlington Limestone. The exact relationships of the Valmeyeran strata to the truncated underlying Kinderhookian strata appear to be poorly understood, and an in-depth study of these relationships might be desirable.

\section{Linear teatures visible on LANDSAT images of western Illinoic}

To determine whether the bedrock structure of Illinuis can be interpreted from satellite imagery, the Illinois Survey mapped the surface distribution of linear features that are visible on LANDSAT images. Some of these

features form a prominent pattern. One set of lincar features in western Illinois has been examined in detail and the results summarlzed below.

Approximately 30 prominent linear teaturês ranglng in size from a mile to as much as 45 miles $(72 \mathrm{~km}$ ) in length can be identified on satellite and high-altitude aerial photography and imagery of western Illinois (fig. 11). These features are mostly active stream valley:; liowever, some of the features are alluviated valleys with no active drainage. In plan view, the linears form an arcuate pattern across the western part of Illinois, extending from Pike Cuunty, west of the Illinois River, Lu the Rock Island area. Towards the southern end of the arcuate pattern, the linears trend approximately $N 65^{\circ} \mathrm{E}$. The orientation gradually shitts to a more easterly dlrecliun until the Iinears at Rock Island trend approximately $\mathrm{N} 90^{\circ} \mathrm{E}$.

The linear features appear to be the product of glaclal and geomorphic processes. The possibility of bedrock faults or joint systems controlling the development of the linears exists but has little supporting evidence. Faulting is evident in cores of Mississippian limestones near the 

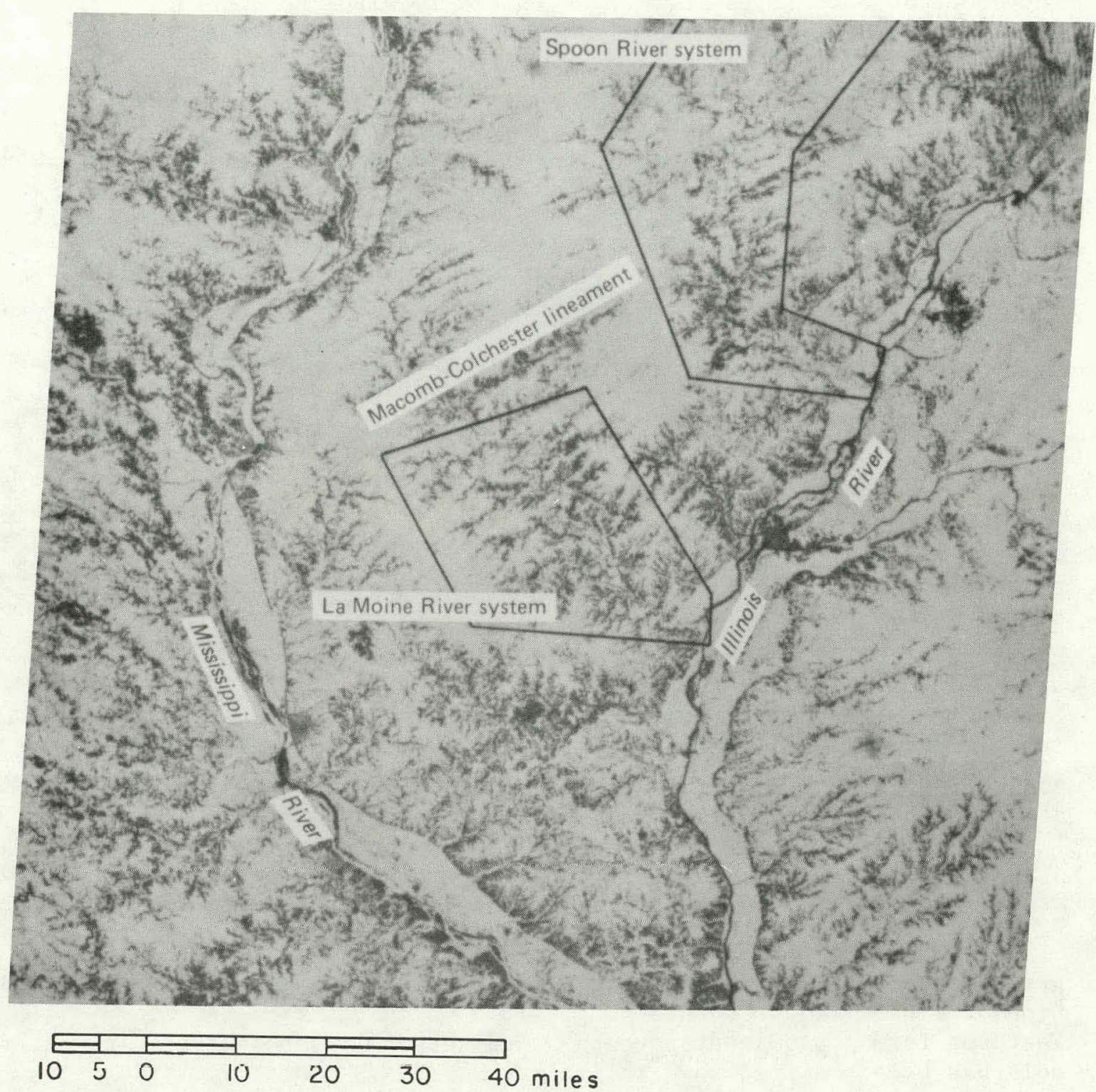

Fig. 11. LANDSAT image of western Illinois taken 14 January 1974. This snow-enhanced winter scene clearly shows the prominent northeastto-southwest-trending linear features that cut across areas of shallow bedrock as well as areas of thick glacial drift. 
Macomb-Colchester lineament. However, the faulting is not expressed in the overlying Pennsylvanian sandstones and there is no evidence of the faults showing through the overlying glacial drift.

One hypothesis on the origin of the lineaments is that the linear valleys were eroded by meltwater streams at the bottom of ice-walled crevasses in an ice sheet that stagnated in western Illinois. This type of feature has been documented previously on the Illinoian Drift Plain by Leighton (1959). This original hypothesis seems unlikely, however, as the linears in western Illinois generally lack large outwash bodies along their channels. Also, the linears appear to cross till boundaries indiscriminately.

A second hypothesis is that the basic morphology of the linears was formed during the last glacial advance in western Illinois. Glacial advances can sometimes construct a system of luw ridges and troughs parallel to the direction of ice movement. This occurs mostly in regions of relatively thin glacial drift as is the case in western Illinois.

Geomorphic processes and loessial deposition have probably altered the post-glacial topography to a large extent. Drainage development evidently took place preferentially along the low lying troughs carved by the glacier. The streams have entrenched themselves since their initial development and now flow on well developed floodplains.

\section{Basic data file for Eastern Gas Shales Project}

A computer file of basic data has been compiled for 5777 holes penetrating the Upper Devonian shales in the southern half of the Illinois Basin. Figure 12 is an index map sliuwing the countics which have been completed to date. Figures 13 through 16 are compuler-produced maps with all holes shown in their proper location by a small cross. Maps of any portion of this completed area can be produced to any desired scale by ILLIMAP (Swann et a1., 1970).

The data conlained in the filc are licted below:

1. Unique well number composed of:

a. State rode.

b. County code

c. County number

2. Company name

3. Holc number

4. Farm name

5. Pool name

6. Legal location composed of:

a. section number

b. township number

c. range number

d. distance from reference section corner in feet

7. Elevation

8. Date of drilling

9. Types of logs available

10. Total depth

11. Type of drilling tools used (rotary or cable) 


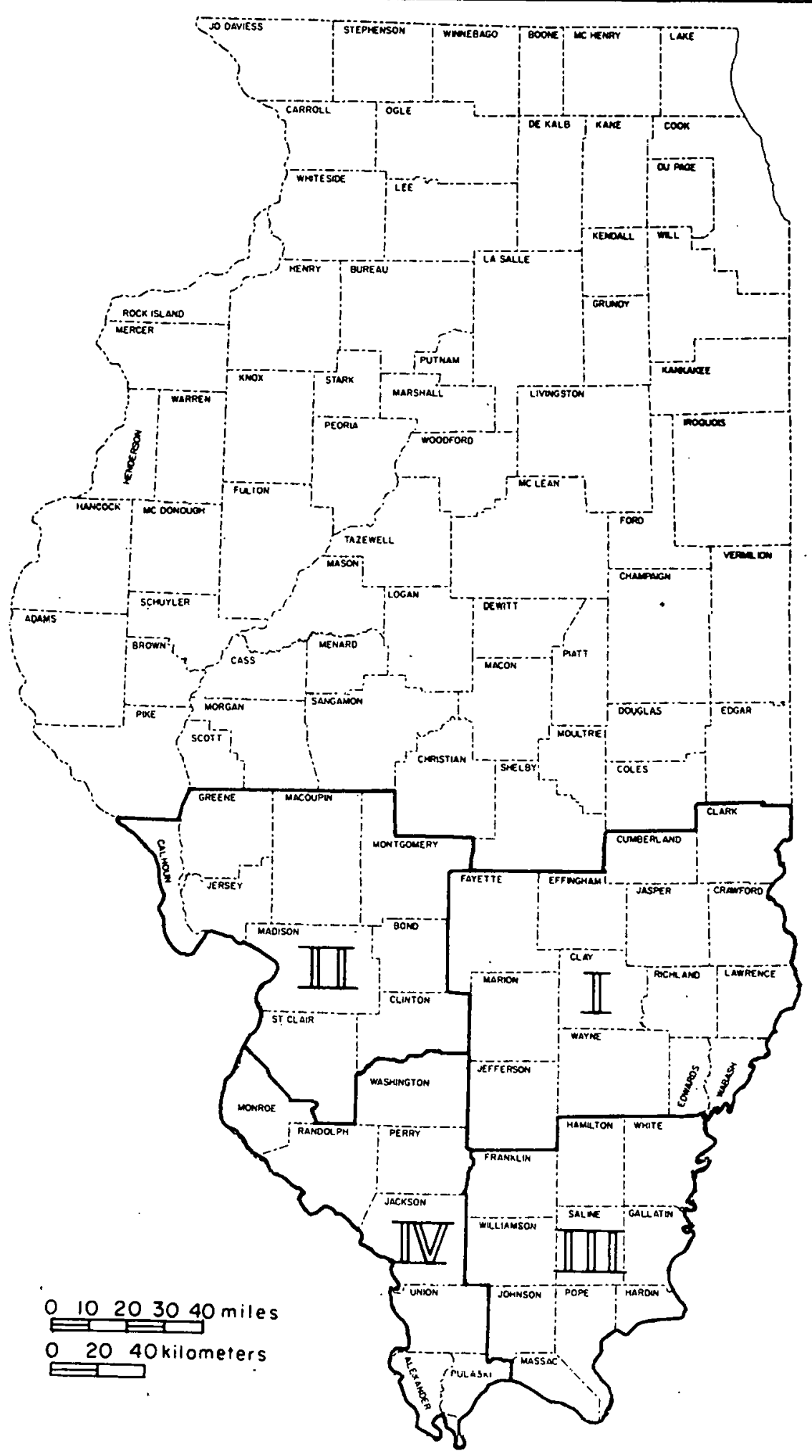

Fig. 12. Index map showing area in which the basic data file for holes penetrating the Middle Devonian shales has been completed. The area is divided into four sections ( $I$ through IV) and individual hole locations are shown on accompanying maps ( $f$ ig. 13 through 16). 
I

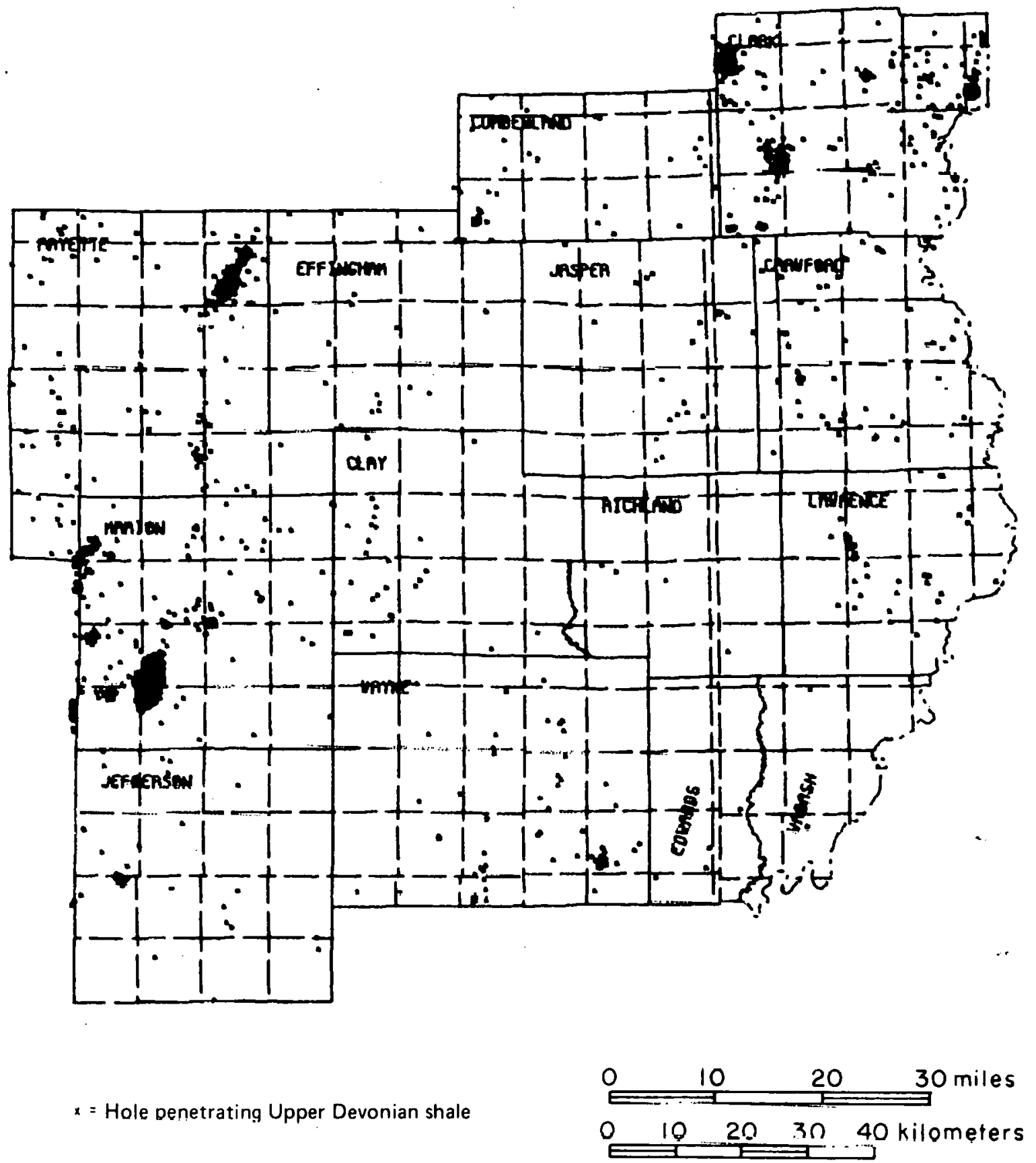

Fig. 13. Devonian well locations, northeast area. 


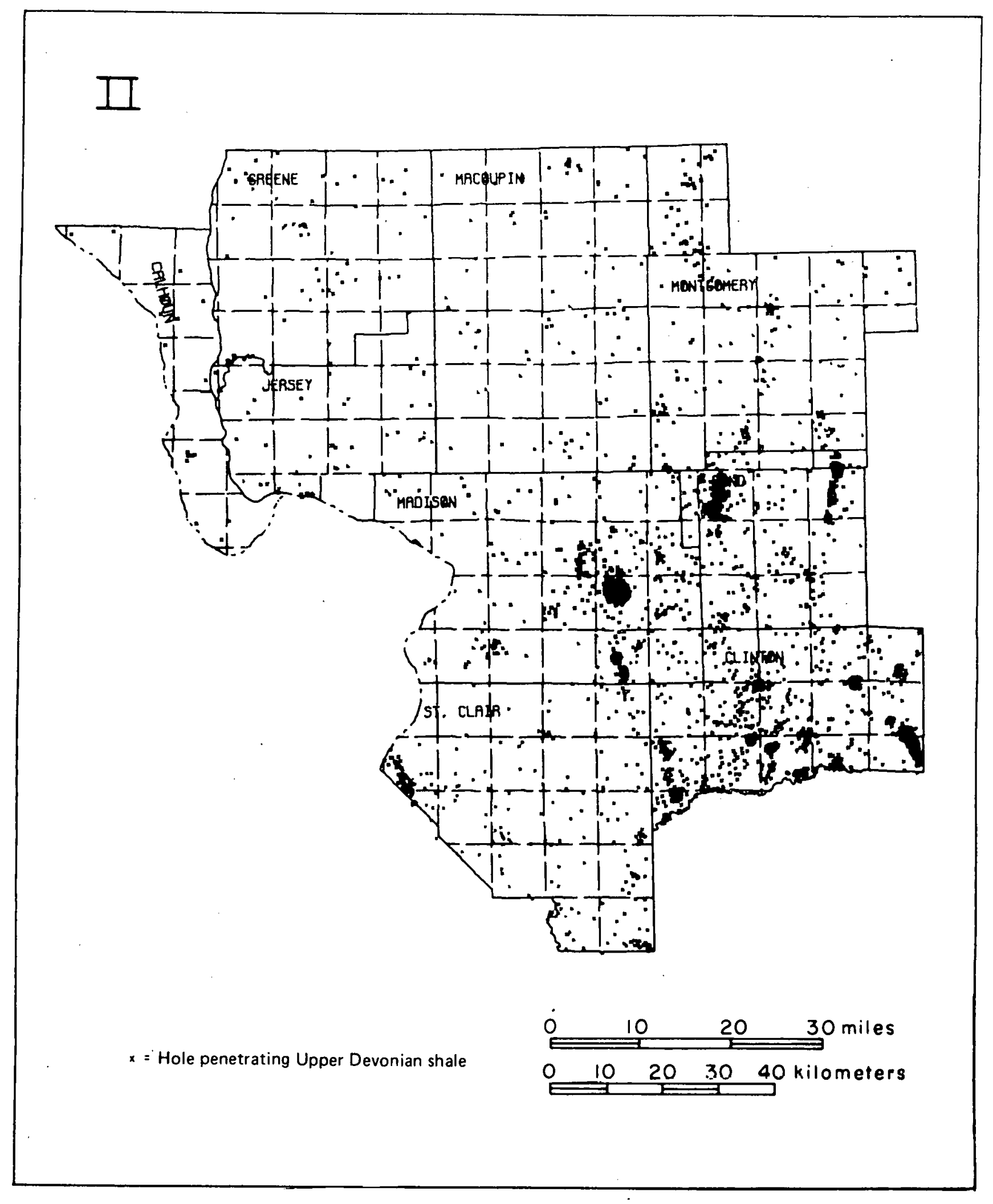

Fig. 14. Devonian well locations, northwest area. 
III

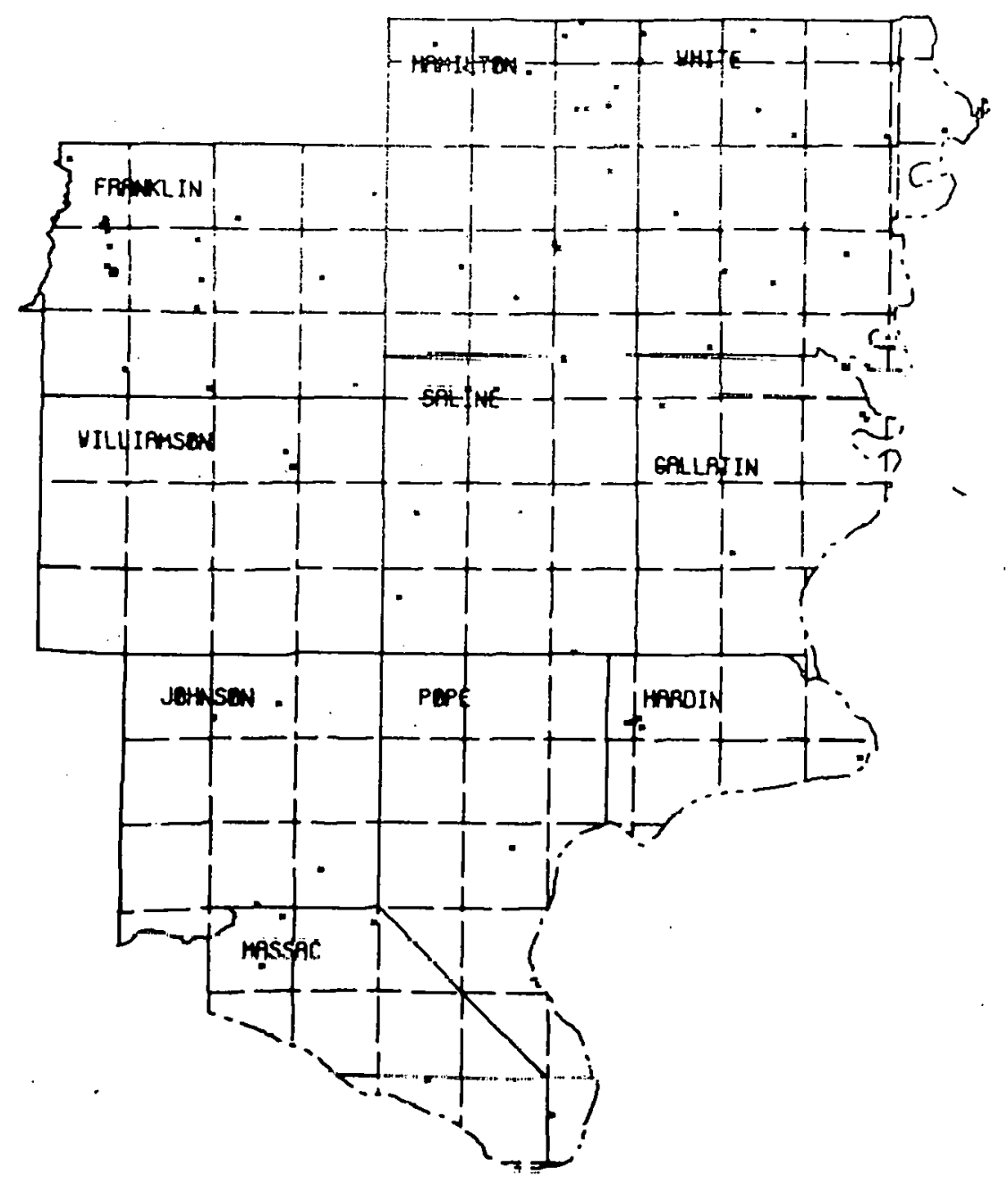

$x=$ Hole penetrating Upper Devonian shäle

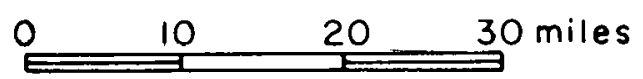

$0 \quad 10 \quad 20 \quad 30 \quad 40$ kilometers

Fig. 15. Devonian well locations, southeast area. 


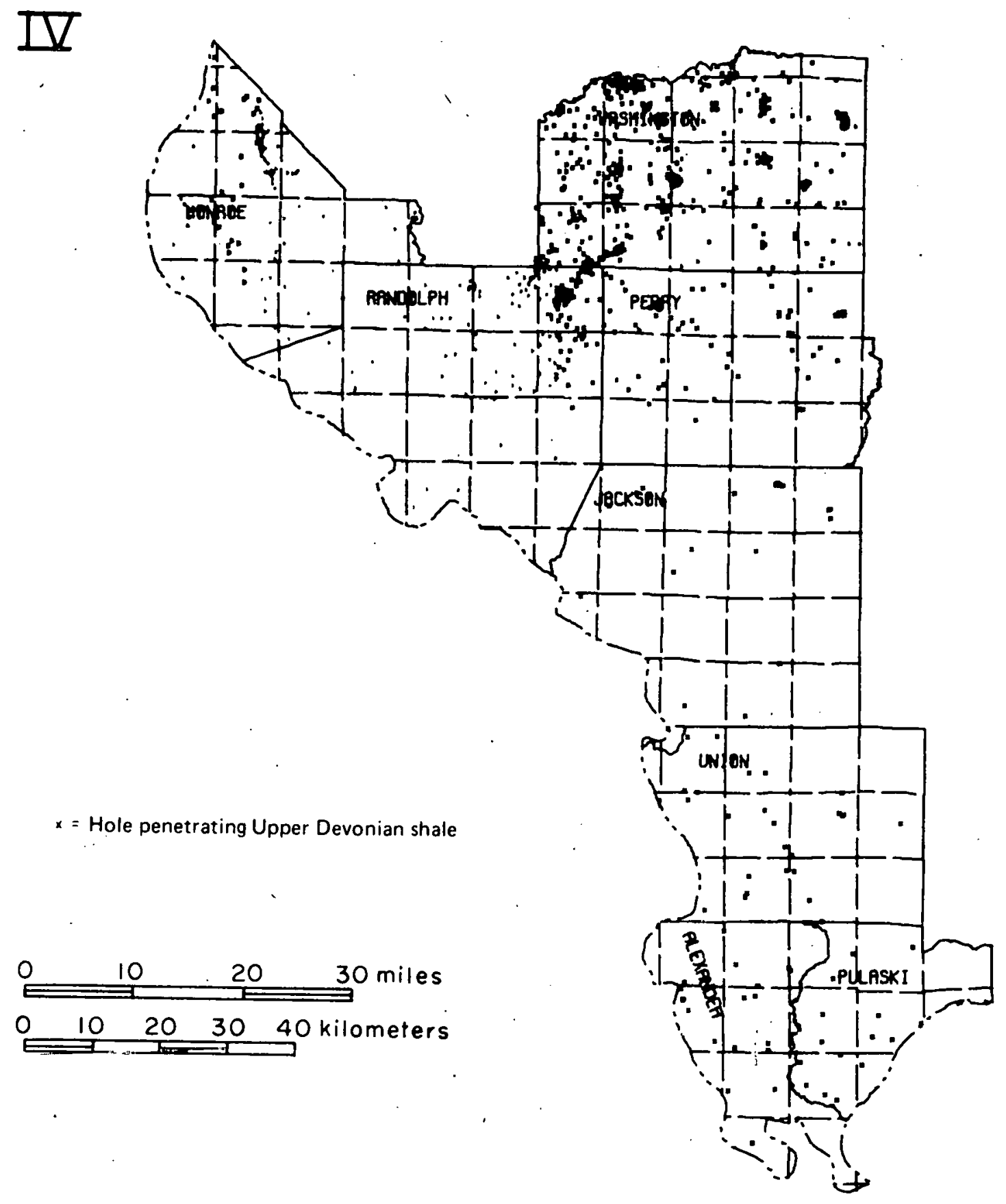

Fig. 16. Devonian well locations, southwest area. 
12. Sample set file number

13. Core file number

14. Name of deepest rock unit penetrated

15. Name of any formations drill stem tested

16. Status of hole (dry hole, producing well, etc.)

17. Name of any pay formation

The basic data file will be expanded to include the northern portion of Illinois that is underlain by Upper Devonian shales. Appropriate stratigraphic data will be added to this file as they are generated. The production of the maps for this study will be facllitated through the use of this file.

\section{REFERENCES}

Atherton, Elwood, C. W. Collinson, and J. A. Lineback, 1975, Mississippian Systen, in Willman, H. B,, et al., 1975, Handbook of Illinois Stratigraphy: Illinois State Geological Survey Bullelin 95, p. 12.3-163.

Bain, H. F., 1895, Central Iowa Section of the Mississippian Series: American Geologist, v. 15, p. 317-325.

Borden, W. W., 1874, Report of a geological survey of Clark and Floyd Counties, Indiana: Indiana Geological Survey Annual Report 5, p. 134-189.

Campbel1, Guy, 1946, New Albany Shale: Geological Society of America Bulletin, v. 57, p. 829-908.

Collinson, C. W., 1961, Kinderhookian Series in the Mississippi Valley, in Northeastell Missouri and west-central Illinois: Kansas Geological Society Guidebook, 26th Annual Field Conference, Missour i Geological Survey Report of Investigar1uns 27, p. 100-109; Illinois State Geological Survey Reprint 1961-U.

Collinson, C. W., and Elwend Atherton, 1975, Devonian System, in Willman, H. B., et al., 1975, Handbook of Illinois straligraphy: I11inois State Geological Survey Bulletin 95, p. 104-123.

Collinson, C. W., L. E. Becker, G. W. James, J. W. Koeni.g, and D. H. SWanm, 1967, T11inois Basin, in International Symposium on the Devonian Systen: Alberta Society of Petroleum Geologists, v. 1. p. 940-962; Illinois State Geological Survey Reprint 1968-G.

Keyes, C. R., 1892, Principal. Mississippian Section: Geological Society of America Bulletin, v. 3, p. 283-300.

Keyes, C. R., 1898, Some geological formations of the Cap-au-Gres uplift: Iowa Academy of Science Proceedings, v. 5, p. 58-63.

Keyes, C. R., 1912, Some provincial and local phases of the general. geologic section of Iowa: Iowa Academy of Science Proceedings, v. 19, p. 147-151. 
Lamar, J. E., W. J. Armon, and J. A. Simon, 1956, Illinois Oil Shales: Illinois State Geological Survey Circular 208, 21 p.

Lineback, J. A., 1968, Subdivisions and depositional environments of New Albany Shale (Devonian-Mississippian) in Indiana: American Association of Petroleum Geologists Bulletin, v. 52, p. 1291-1303.

Leighton, M. M., 1959, Stagnancy of the Illinoian glacial lobe east of the Illinois and Mississippi Rivers: Journal of Geology, v. 67, p. 337-344.

Moore, R. C., 1928, Early Mississippian formations in Missouri: Missouri Bureau of Geology and Mines, v. 21, 283 p.

North, W. G., 1969, Middle Devonian strata of southern Illinois: Illinois State Geological Survcy Circular 441, 45 p.

Penrose, R. A. F., Jr., 1891 , Manganese, its uses, ores, and deposits: Arkansas Geological Survey Annual Report 1890, 642 p.

Stevenson, D. L., and D. R. Dickerson, 1969, Organic Geochemistry of the New Albany Shale in Illinois: Illinois State Geological Survey, Illinois Petroleum $90,11 \mathrm{p}$.

Swann, D. H., and A. H. Bell, 1958, Habitat of oll in the Illinois Basin, in Weeks, L. G., editor, Habitat of oil: American Association of Petroleum Geologists, Tulsa, p. 447-472.

Swann, D. H., P. B. DuMontelle, R. F. Most, and L. H. Van Dyke, 1970, ILLIMAPA computer-based mapping system for Illinois: Illinois State Geological Survey Circular 451, $24 \mathrm{p}$.

Udden, J. A., 1899, Sweetland Creek beds: Journal of Geology, v. 7, p. 65-78.

Ulrich, E. 0., 1904, in E. R. Buckley and H. A. Buehler, Quarrying industry of Missouri: Missouri Bureau of Geology and Mines, v. 2, 371p.

Whiting, L. L., and D. L. Stevenson, 1965, Sangamon Arch: Illinois State Geological Survey Circular 383,20 p.

Workman, L. E., and Tracey Gillette, 1956, Subsurface stratigraphy of the Kinderhook Series in Illinois: Illinois State Geological Survey Report of Investigations $189,46 \mathrm{p}$. 


\title{
IIG. Mineralogic and petrographic characterization of New Albany in Illinois
}

\author{
R. D. Harvey, R. M. Cluff; and W. A. White
}

SCOPE AND PURPOSE

This project is directed at characterizing in detail the mineralogic and petrographic properties of the New Albany Shale Group in Illinois. This includes the quantitative and qualitative characterization, by optical and $\mathrm{X}$-ray techniques, of the lnurganic mineral ronstituents, the dispersed organic matter, and the fablic of the shale. The data generated will provide a fundamontal basis for regional dud local uelitintione of genlogic data, lui inlerpretation of the sedimentology, depositiunal environmont, and diagenet1c hlstory, and for: evaluation of hydrocarbon potentials based on the degree of thermal maturation of organic matter in the New Albany Shale.

\section{ACCOMPLISHMENTS}

(1) Project personnel were hired.

(2) Leitz MPV II research microscope for reflectance studies was acquired and tested.(Milestone 19).

(3) Fluorescence of sporps and other organic matter was observed with our available xenon ldup, but quantitative evaluation of the fluvestence was not possible. An interference. filter wedge and a mercury lamp are needed for furthor studies.

(4) A core handling and sample preparation procedure was established.

(5) Sample preparation, X-ray diffraction and radiography, micro. scopic analysis, and geologic evaluation of core 01IL, Sangamon County, I111nuis were completed (Milestone 20).

(G) Samc etaps as for item 5 were completed for core 01KY, Christian County, Kentucky (Milestone 24).

(7) Samplp preparation and study of 5 additional New Albany cores in Illinois were initiated.

(8) Paper entitled "Petrology of New Albany Shale Group (Upper Devonian and Kinderhookian) in the Illinuis Basin-A Preliminary Report" was presenced at EGSP symposium in Morgantown, West Virginia, October 18, 1977. 


\title{
METHODS OF ANALYSES AND PROCEDURES
}

\author{
Analyses
}

The mineralogic and petrographic properties investigated for this project, the methods of analyses, and the types of samples needed for each analysis are 1isted in table 1 . The mineralogy was determined mainly by X-ray diffraction of powders and smoothed slabs of the core segments selected for study. The $\mathrm{X}$-rays were generated from a copper target and passed through a graphite crystal oriented so that only the $\mathrm{K}$ diffraction radiation passes through the crystal and into the collimator. ${ }^{\alpha}$ The samples were scanned at. 2 degrees $2 \theta$ per minute. The X-ray diffraction signal was set at 500 counts full scale.

Various types of microscopic techniques were used for mineralogical and other analyses-especially transmitted-light microscopy of specially prepared thin sections of the shales and vertical reflected light microscopy of polished slabs and of specially prepared, particulate grain mounts.

Radiographic analyses were made of oriented slabbed samples ( $f$ g. 17), which were cut about $\frac{1}{4} \times 4 \times 4$ in. and $\mathrm{X}$-rayed with a Picker Industrial MiniShot apparatus. A radiograph consists of a sheet of type $M$ industrial $X-r a y$ film exposed to $\mathrm{X}$-rays passing through the slab sample for 3 min at $38 \mathrm{kV}$ : Different parts of the radlograph are exposed differently depending on the relative density, texture, and structure of different parts of the slabbed sample.

\section{Procedures}

The preparation of the samples for the various analyses made for the mineralogic and petrographic characterizations are shown in figure 18. A: clay fraction $(<2 \mu \mathrm{m})$ was separated from a crushed sample for clay mineral analyses. The clay was dispersed in distilled water with a deflocculant ( 80 percent sodium hexametaphosphate and 20 percent sodium carbonate) and allowed to stand until all particles greater than $2 \mu \mathrm{m}$ had settled. The top $40 \mathrm{~mm}$ were then siphoned off, flocculated, centrifuged for $10 \mathrm{~min}$ and mixed; smear (random oriented clay) slides of this material were made. These slides were allowed to air dry and then were placed in an atmosphere of ethylene glycol for 1 wk before X-ray diffraction analyses were made. The relative abundances of the various clay minerals in the sample were determined by the method used by Odom and Parham (1968).

The clay mineral orientation index was determined by $\mathrm{X}$-ray diffraction of a smoothed slab of the sample cut perpendicular to the bedding and mounted on a glass slide. This section was placed in the $X$-ray holder so that the same beds (laminae) were $X$-rayed from 2.5 to 22.5 degrees $2 \Theta$.. The areas of the peaks at $4,8.8,12.5$, and 19.5 to 20.0 degree $2 \theta$ were determined. The orientation index is the ratio of the area of the 19.5 to 20.0 peak to the sum of the areas determined for the other listed peaks. Depending on the intensity of the peaks (001 and hk1), adjustments for some samples had to be made for the particular clay minerals and micas present. 
TABLE 1-MINERALOGIC AND PETROGRAPHIC ANALYSES, METHODS AND TYPES OF SAMPLS

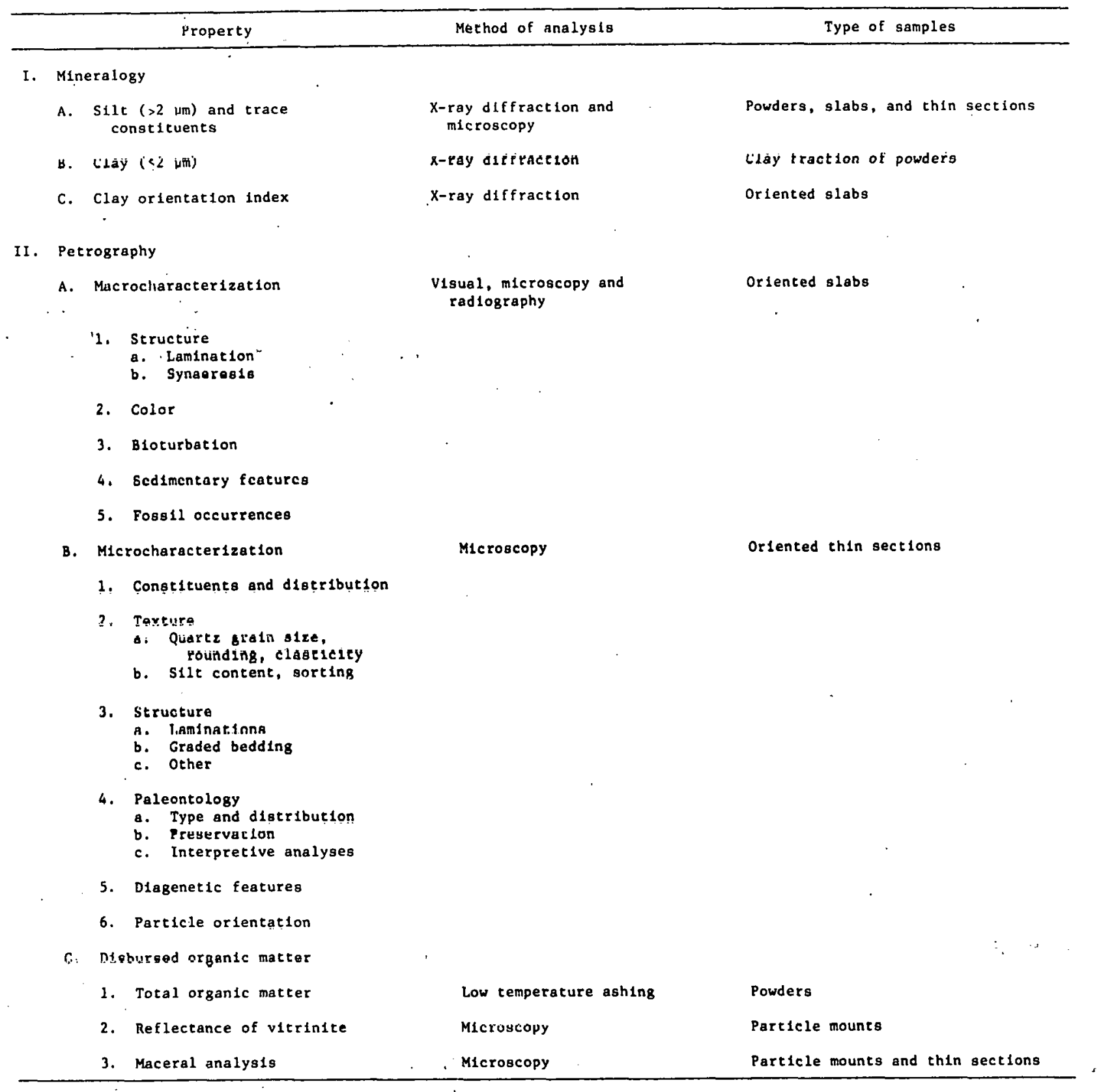




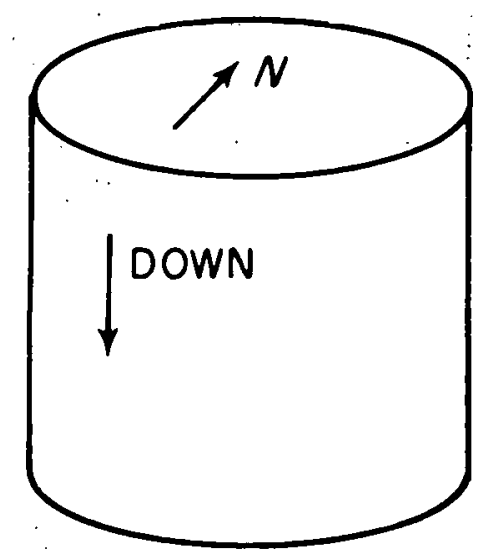

A. Orientetion of the core segment.

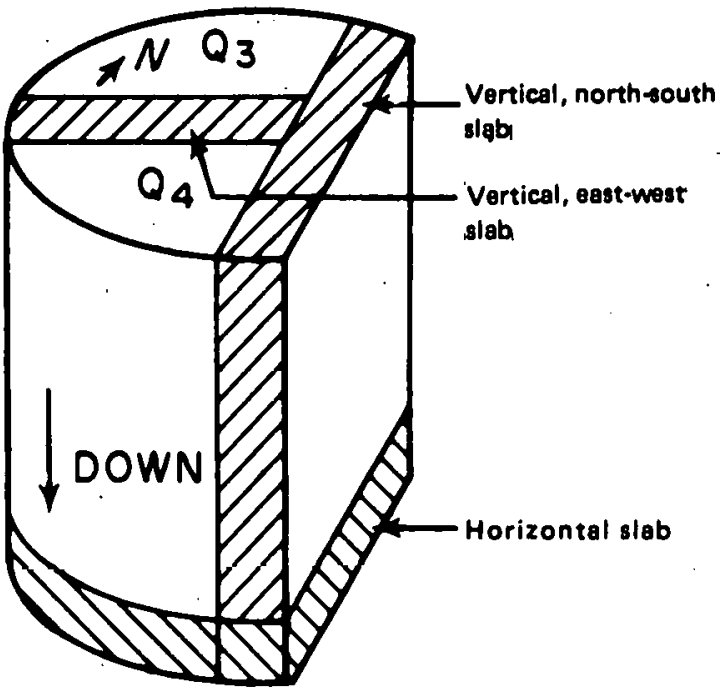

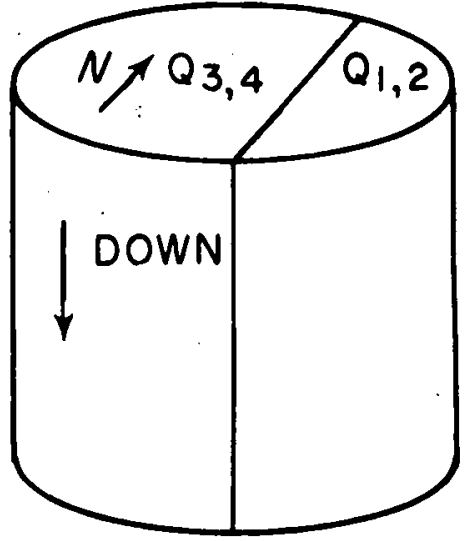

B. The core segment is soaked in distilled weter prior to sawing with tap water lubrication. The two pieces, $Q_{1,2}$ and $Q_{3,4}$, are cleaned, then rinsed in distilled water. After drying, $Q_{1,2}$ is crushed and pulverized for various tests. $Q_{3,4}$ is cast in epoxy to hold it together during subsequent sewing.

C. Three oriented slabs are cut for petrographic anal-

yses. Saw cuts are made with kerosene lubricant. $Q_{3}$ is returned to archive storage.

F1. 17. Diagram showing the procedures used to obtain samples for mineralogic, petrographic, and chemical analyses from core segments of New Albany shales. 


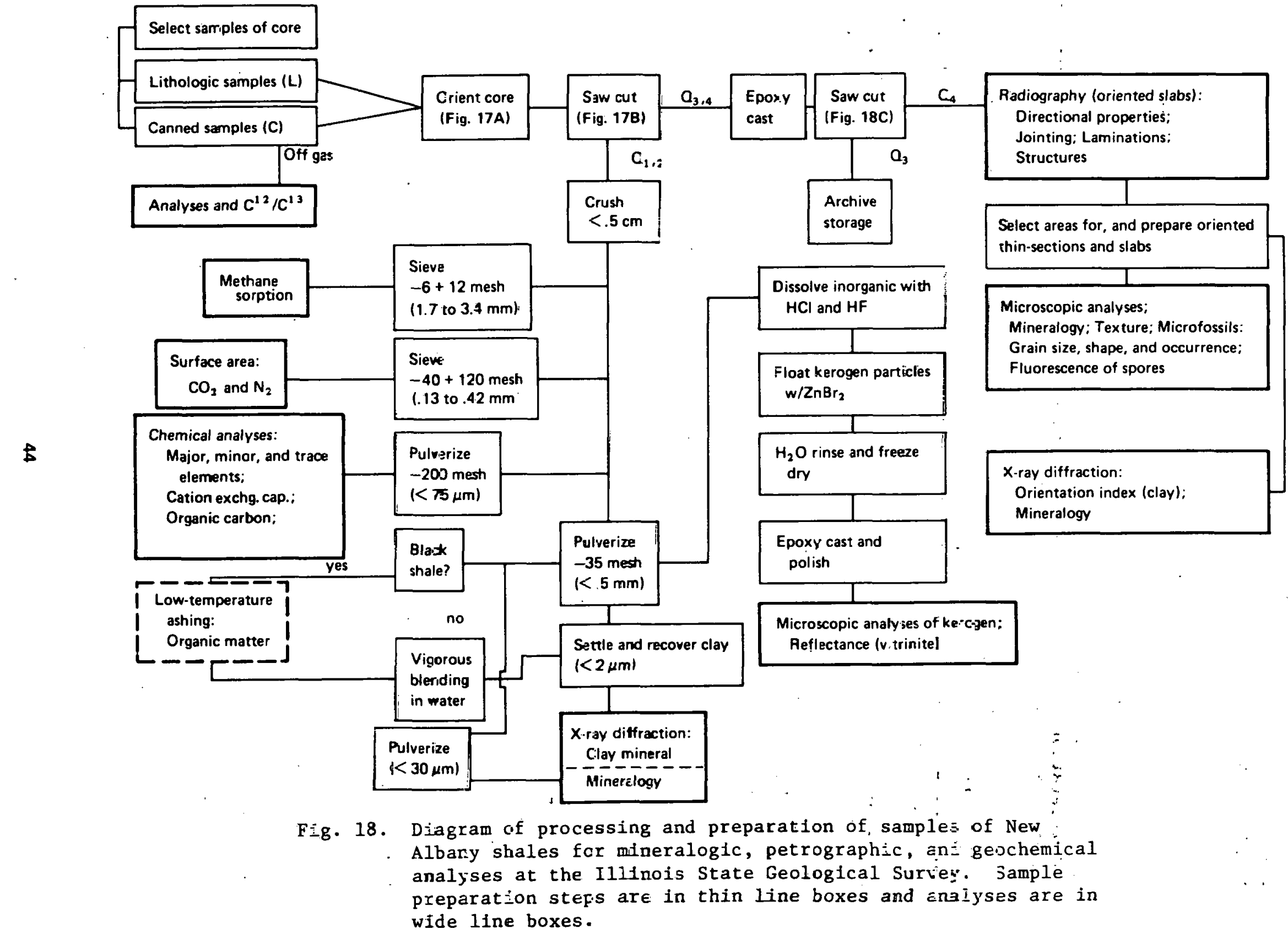


Oriented thin sections, prepared using kerosene lubrication during sawing and grinding stages, were ground to about $60 \mu \mathrm{m}$ on a Microtec thinsection machine and were then hand ground to about $30 \mu \mathrm{m}$ thick.

RESULTS

Location and stratigraphic position of the samples studied

Mineralogic and petrographic studies have centered on analyses and interpretations of data obtained on samples from two cores, one from Sangamon County, Illinois, identified as 01IL, and the other from Christian County, Kentucky, 01KY ( $f 1 g .1$ ). The entire thickness of the New Albany in both cores is represented by the samples studied. The stratigraphic position of the samples from 01IL and $01 \mathrm{KY}$ are shown respectively in figures $3 \mathrm{ab}$ and $2 \mathrm{a}$. In the OlIL core, sample OlLl is of the Chouteau Limestone which overlies the New Albany in the area. Samples 01L2 through 13L1 are of the Hannibal-Saverton Shales. Within this group of samples, 08L1 is 1imestone from the "Glen Park" Formation. In this core the Grassy Creek Shale is represented by samples $14 \mathrm{Ll}$ through 19L1, and the underlying Sweetland Creek Shale is represented by 20L1 and $21 \mathrm{Ll}$ (fig. 3b). In the 01KY core, the uppermost formation of the New Albany Group is the Grassy Creek Shale, represented by samples 01Ll through 05Li. The underlying Sweetland Creek Shale is represented by samples 06C1 through $11 \mathrm{Cl}$, and the Blocher Shale is represented by $12 \mathrm{Cl}$ through $13 \mathrm{Cl}$ (fig. 2a).

\section{Mineralogy}

\section{Silt and trace constituents}

$X$-ray diffraction (XRD) and thin-section microscopy of the samples from both cores studied indicate the silt-sized ( $>2 \mu \mathrm{m}$ diameter and larger) minerals are mainly quartz, feldspar (both microcline and plagioclase types), carbonate (mainly dolomite with some samples bearing calcite), and pyrite. Their total abundance in the samples varies ronsiderably from about 5 percent (sample 01ILIlL1) to 85 percent (sample 01IL07L1). The remaining constituents are clay minerals $(<2 \mu \mathrm{m}$ in size) and traces of other silt mineral grains and dispersed organic matter (kerogen). The clay mineralogy and the organic matter will be discussed in later sections.

The results of the analyses of the silt minerals are listed in tables 2 and 3 . The sample numbers listed in these and subsequent tables are the last four ciphers of the sample number assigned to each. The data are given in several forms which are derived frnm hoth XRD and microscopic analyses. The maximum peak height of a characteristic XRD peak for the main minerals are 1isted in counts/sec of X-rays, abbreviated in the tables as "cts." The Bragg diffraction angle for the peak is given for each mineral" in the column heading. The relative number of counts for each mineral among the samples 1isted in the table is also given under the heading "rel." This is to assist in ranking the samples from the most (1.0) to the least abundant of that mineral. These data cannot be converted directly into percentage values but they are roughly proportional to the abundance of the mineral in the sample. Percentages were estimated for quartz, feldspar, and carbonate by microscopic 
TÁ3LE 2-SILT MINERALOGY, SANGAMON COUNTY, ILLINOIS CORE SAMPLES (OIIL)

\begin{tabular}{|c|c|c|c|c|c|c|c|c|c|c|c|c|c|c|c|c|c|}
\hline $\begin{array}{l}\text { Sample } \\
\text { Number }\end{array}$ & Depth $(f t$.$) .$ & \multicolumn{2}{|c|}{$\begin{array}{c}\text { Quartz } \\
20.8^{\circ} 20\end{array}$} & \multicolumn{2}{|c|}{$\begin{array}{l}\text { Tot. feldspar } \\
23.5-23.8^{\circ} 20\end{array}$} & $\begin{array}{c}\text { K-feldspar/ } \\
\text { Plagfoclase } \\
\left(27.6^{\circ} / 27.7^{\circ}\right)\end{array}$ & 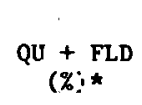 & $\begin{array}{l}\text { Mica }+ \\
\text { i9.8 } \\
\text { cts. }\end{array}$ & $\begin{array}{l}\text { Clay } \\
20 \\
\text { rel. }\end{array}$ & \multicolumn{2}{|c|}{$\begin{array}{l}\text { Calcite } \\
29.4^{\circ} 20\end{array}$} & \multicolumn{2}{|c|}{$\begin{array}{l}\text { Dolomite } \\
30.8^{\circ} 2 \Theta\end{array}$} & $\begin{array}{l}\text { Zarbonate } \\
(\%)^{+}\end{array}$ & $\begin{array}{c}\mathrm{PY}+\mathrm{MA} \\
(\%) \star \star\end{array}$ & $\begin{array}{c}\text { Siterite and/or } \\
\text { Apatite }^{\dagger}\end{array}$ & Other \\
\hline $01 L 2$ & 1576.0 & 165 & .4 & 30 & .4 & $45 / 55$ & -5 & $\subseteq 5$ & .4 & 15 & .05 & 60 & .1 & $<5$ & tr & $\dot{X} R D$ & \\
\hline $03 \mathrm{LI}$ & 1589.4 & 290 & .7 & 65 & .9 & $40 / 60$ & 50 & $\epsilon 0$ & .2 & 0 & -- & 100 & .2 & $5-10$ & .1 & XRD & \\
\hline $04 \mathrm{Ll}$ & 1602.0 & 430 & 1.0 & 70 & 1.0 & $45 / 55$ & 60 & 75 & .3 & 0 & -- & 55 & .1 & $<5$ & .1 & XRD & \\
\hline $05 \mathrm{~L} 1$ & 1615.1 & 295 & .7 & 45 & .65 & $50 / 50$ & is & 65 & .3 & 0 & -- & 40 & .1 & $<5$ & .1 & XRD & \\
\hline $06 \mathrm{Ll}$ & 1619.5 & 385 & .9 & 50 & .7 & $45 / 55$ & 70 & 35 & .1 & 5 & .05 & 60 & .1 & $<5$ & $\tau r$ & XRD & Heavy min." \\
\hline $07 L 1$ & 1631.6 & 180 & .4 & 40 & .55 & $40 / 60$ & $\$ 5$ & 30 & .1 & 500 & 1.0 & 45 & .1 & $30-35$ & .1 & XRD & \\
\hline $07 \mathrm{~L} 2$ & $1: 34.1$ & 110 & .3 & 35 & .5 & $50 / 50$ & $<5$ & 60 & .2 & 45 & .1 & 500 & 1.0 & $>75$ & tr & & \\
\hline $09 \mathrm{L1}$ & 1647.4 & 155 & .4 & 35 & .5 & so/so & 10 & 105 & .4 & 0 & -- & 35 & .1 & $<5$ & .2 & XRD & \\
\hline $09 \mathrm{~L} 2$ & 1656.2 & 160 & .4 & .25 & .35 & $0 / 100$ & 15 & $10 \overline{5}$ & .4 & 10 & .05 & 20 & .05 & 2 & .5 & XRD & \\
\hline $10 \mathrm{~L} 1$ & 1657.6 & 285 & .7 & 35 & .5 & $50 / 50$ & 30 & $2 j$ & .1 & 0 & - & 0 & - & 1 & 1.7 & XRD & \\
\hline $11 \mathrm{Ll}$ & 1667.5 & 130 & .3 & 45 & .65 & $100 / 0$ & $<5$ & $181)$ & .7 & 0 & -- & 15 & .05 & 1 & .5 & XRD & \\
\hline $12 \mathrm{LI}$ & 1678.6 & 185 & .5 & 55 & .8 & $100 / 0$ & 5 & 17.5 & .7 & 0 & -- & 25 & .05 & 1 & .3 & XRD & \\
\hline $13 \mathrm{~L} 1$ & 1688.0 & 120 & .3 & 35 & .5 & $100 / 0$ & $<5$ & 210 & .9 & 0 & -- & 25 & .05 & 1 & .6 & XRD & marcasite ${ }^{+}$ \\
\hline $14 \mathrm{~L} 1$ & 1698.2 & 150 & .4 & 40 & .55 & $100 / 0$ & 10 & 0 & .0 & 0 & -- & 0 & -- & 1 & 1.0 & XRD & \\
\hline $15 \mathrm{Ll}$ & 1710.0 & 195 & .5 & 70 & 1.0 & $100 / 0$ & 5 & 245 & 1.0 & 25 & .05 & 35 & .05 & 1 & 1.7 & XRD & \\
\hline $16 \mathrm{LI}$ & 1723.4 & 230 & .6 & $\therefore 5$ & .65 & $45 / 55$ & 10 & 165 & .7 & 15 & .05 & 15 & .05 & 1 & 2.4 & XRD & $\begin{array}{c}\text { marcasite } \\
\text { glauconite }\end{array}$ \\
\hline $17 \mathrm{LI}$ & 1730.6 & 245 & .6 & 50 & .7 & $50 / 50$ & 10 & 170 & .7 & 0 & -- & 0 & -- & 1 & 2.1 & XRD & \\
\hline $18 \mathrm{~L} 1$ & 1740.2 & 200 & .5 & 30 & .4 & $50 / 50$ & 10 & 140 & .6 & 0 & -- & 15 & .0 .5 & 2 & 1.7 & $\mathrm{XRD}$ & \\
\hline $19 \mathrm{~L} 1$ & 1753.5 & 165 & .4 & 40 & .55 & $50 / 50$ & 5 & 180 & .7 & 0 & - & 35 & .05 & 1 & 2.5 & XRD & $\operatorname{marcasite}{ }^{\dagger}$ \\
\hline $20 \mathrm{LI}$ & 1763.3 & 190 & .5 & $\therefore 0$ & .55 & $0 / 100$ & $<5$ & 120 & .5 & 5 & .05 & 70 & .15 & 5 & 1.6 & XRD & marcasite $e^{\dagger}$ \\
\hline $21 \mathrm{~L} 1$ & 1776.2 & 135 & .3 & 45 & .65 & $50 / 50$ & $<5$ & 190 & .8 & 0 & -- & $40^{\circ}$ & .1 & 1 & 1.3 & XRD & $\operatorname{marcasite}_{\text {gaucontte }}^{\|}$ \\
\hline
\end{tabular}

*Estimate for quartz + feldspar ix-feldspar + plagluclase based on thin. section microsropy.

tEstimate for calcite + dolomite + siderite (?) content based on compartsor of $\mathrm{CO}_{2}$, thin section ancroscopy and $x$-ray diffiaction daza.

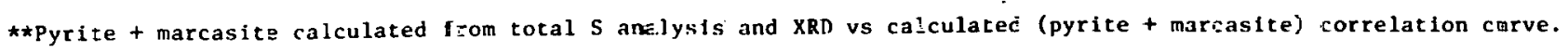

†identified as present in samples indicated; method of analysis was by XRD. Sample 0SLl contains a minor amount, all other samples contain trace amount

"Identified as present in the sample in trace amounts by thin section mi=rescopy. 
TABLE 3-SILT MINERALOGY, CHRISTIAN COUNTY, KENTUCKY CORE SAMPLES (OIKY)

\begin{tabular}{|c|c|c|c|c|c|c|c|c|c|c|c|c|c|c|c|c|c|}
\hline \multirow{2}{*}{$\begin{array}{l}\text { Sample } \\
\text { Number }\end{array}$} & \multirow{2}{*}{ Depth (ft.) } & \multicolumn{2}{|c|}{$\begin{array}{l}\text { Quartz } \\
20.8^{\circ} 2 \theta\end{array}$} & \multicolumn{2}{|c|}{$\begin{array}{l}\text { Tot. feldspar } \\
23.5-23.8^{\circ} 2 \theta\end{array}$} & \multirow{2}{*}{$\begin{array}{c}\text { K-feldspar/ } \\
\text { Plagio clase } \\
(27.6 \% / 27.90)\end{array}$} & \multirow{2}{*}{$\begin{array}{c}\mathrm{QU}+\mathrm{FLD} \\
(\mathrm{q}) \star\end{array}$} & \multicolumn{2}{|c|}{$\begin{array}{c}\text { Mica + Clay } \\
19.8^{\circ} 20\end{array}$} & \multicolumn{2}{|c|}{$\begin{array}{l}\text { Calcite } \\
29.4^{\circ} 20\end{array}$} & \multicolumn{2}{|c|}{$\begin{array}{l}\text { Dolomite } \\
30.8^{\circ} 20\end{array}$} & \multirow{2}{*}{$\begin{array}{c}\text { Carbopate } \\
(\%)^{-1}\end{array}$} & \multirow{2}{*}{$\begin{array}{c}\dot{P Y}+\mathrm{MA} \\
(\bar{z}) \star \star\end{array}$} & \multirow{2}{*}{$\begin{array}{l}\text { Siderite and/or } \\
\text { Apjatite }^{\dagger}\end{array}$} & \multirow[b]{2}{*}{ Other } \\
\hline & & cts & rel. & cts. & rel. & & & crs. & rel. & cts & rel. & cts & rel. & & & & \\
\hline $01 \mathrm{L1}$. & 2181.2 & 150 & .75 & 35 & .7 & $50 / 50$ & 15 & 130 & .6 & 0 & - & 0 & - & 0 & $5-10$ & XRD & Marcasite ${ }^{t}$ \\
\hline $01 \mathrm{cl}$ & 2182.4 & 175 & .85 & 45 & .9 & $0 / 100$ & $5-25$ & 50 & .2 & 0 & - & 0 & - & $<5$ & 4.5 & $\mathrm{XRD}$ & \\
\hline $02 \mathrm{Ll}$ & 2188.8 & 170 & .85 & 30 & .6 & $0 / 100$ & 15 & 100 & .4 & 0 & - & 65 & .15 & $5-10$ & 4.5 & & Marcasite $^{\dagger}$ \\
\hline $02 \mathrm{Cl}$ & 2191.3 & 205 & 1.0 & 35 & .7 & $0 / 100$ & $5-25$ & 30 & .1 & 0 & - & 85 & .2 & $5-10$ & 3.4 & XRD & \\
\hline $03 \mathrm{LL}$ & 2216.9 & 205 & 1.0 & 25 & .5 & $0 / 100$ & 10 & 60 & .2 & 0 & - & 75 & .2 & $5-10$ & 3.3 & XRD & Marcasite ${ }^{\dagger}$ \\
\hline $03 \mathrm{Cl}$ & 2220.4 & & & & & & $5-25$ & & & & & & & $5-15$ & 3.6 & & Glauconitel \\
\hline $04 \mathrm{Cl}$ & 2230.3 & & & & & & $<5$ & & & & & & & $5-15$ & 0.7 & & \\
\hline 0421 & 2231.2 & 145 & .7 & 30 & .6 & $50 / 50$ & 20 & 130 & .6 & 0 & - & 35 & .1 & $<5$ & 4.5 & XRD & Marcasite ${ }^{t}$ \\
\hline $05 \mathrm{Cl}$ & 2240.3 & & & & & & $5 \div 25$ & & & & & & & $5-15$ & 4.3 & & Glauconitef \\
\hline $05 \mathrm{~L} 1$ & 2244.3 & 165 & .8 & 30 & .6 & $0 / 100$ & 10 & 145 & .6 & 0 & - & 30 & .05 & $<5$ & 2.2 & XRD & Marcasite ${ }^{\dagger}$ \\
\hline $06 \mathrm{Cl}$ & 2250.2 & & & & & & $<5$ & & & & & & & $5-15$ & 0.4 & & \\
\hline $06 \mathrm{~L} 1$ & 2255.6 & 17.5 & .85 & 45 & .9 & $50 / 50$ & $<5$ & 230 & 1.0 & $\mathbf{0}$ & - & so & .1 & $<5$ & 2.0 & XRD & \\
\hline $07 \mathrm{CI}$ & 2260.3 & & & & & & $5-25$ & & & & & . & & $<5$ & 3.3 & & \\
\hline $07 \mathrm{~L} 1$ & 2263.9 & 150 & .75 & 30 & .6 & $55 / 45$ & 10 & 85 & .4 & 0 & - & 415 & 1.0 & $5-25$ & 1.8 & $\mathrm{XRD}$ & Heavy miner. \\
\hline $08 \mathrm{Cl}$ & 2270.5 & 170 & .85 & 35 & .7 & $50 / 50$ & $5-25$ & 150 & .7 & 0 & - & 110 & .2 & $5-15$ & 1.0 & $\mathrm{XRD}$ & \\
\hline $09 \mathrm{Cl}$ & 2280.2 & 135 & .65 & 35 & .7 & $50 / 50$ & $<5$ & 75 & .3 & 0 & - & 360 & .85 & $15-25$ & 1.2 & XRD & \\
\hline $10 \mathrm{C} 1$ & 2290.9 & 175 & .85 & 50 & 1.0 & $50 / 50$ & $5-25$ & 140 & .6 & 0 & - & 135 & .3 & $5-15$ & 1.2 & $\mathrm{XRD}$ & Marcasite $^{\dagger}$ \\
\hline $11 \mathrm{Cl}$ & 2300.0 & 150 & .75 & 50 & 1.0 & $50 / 50$ & $<5$ & 135 & .6 & $\mathbf{0}$ & - & 125 & .3 & $15-25$ & 2.6 & $\mathrm{XRD}$ & \\
\hline $12 \mathrm{C} 1$ & 2310.6 & 175 & .85 & 40 & .8 & $100 / 0$ & $<5$ & 105 & .5 & 35 & .3 & 210 & .5 & $20-25$ & 1.9 & XRD & Basaluminite $^{\dagger}$ \\
\hline $13 \mathrm{Cl}$ & 2319.0 & 180 & .9 & 40 & .8 & $100 / 0$ & $<5$ & 85 & .4 & 120 & 1.0 & 120 & .3 & $20-25$ & 2.2 & XRD & Basaluminite ${ }^{\dagger}$ \\
\hline
\end{tabular}

${ }^{+}$Estimate for calcite + dolonite + siderite (?) =ontent based on comparison of $\mathrm{CO}_{2}$, thin-section microscopy, and $\mathrm{X}$-ray diffraction (XRD) data.

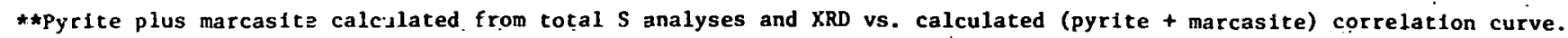

tIdentified as present in trace amounts in samples indicated. Method of analysis was by XRD.

fIdentified as present in tige samples in trace amounts by thin section microscopy. 
examination of thin sections. Because quartz and feldspar are virtually indistinguishable at the fine grain size typlcal of these samples, a single value is given which includes both minerals. The values are listed under the column heading "QU + FLD," but the percentages are dominantly that of quartz. For similar reasons, calcite and dolomite are grouped under "carbonates" in tables 2 and 3 .

Microcline (K-feldspar) and plagioclase feldspars occur in the sam... ples, and they are distinguished from one another by XRD peaks at $27.6^{\circ}$ and $27.9^{\circ} 2 \theta$, respectively. The ratio of these two minerals in the samples are shown in tables 2 and 3 . The XRD pattern of the plagioclase feldspar is similar to the standard oligoclase in many samples, although interpretation "of the feldspar data is complicated by the occurrence of mica in the samples. Measurements of albite twinning extinction angle on a few grains in thin sections also suggest that the plagioclase composition is roughly $\mathrm{Ab}_{100}$ to $\mathrm{Ab}_{70} \mathrm{An}_{3} \mathrm{a}$, or albite to oligoclase (sample 1KY4L1). Microscop1c examination shows about 5 percent or less of each sample to consist of mica in the form of flakes or blades about $2 \mu \mathrm{m}$ thick and 10-20 $\mathrm{m}$ 1ong. The XRD patiern of the samples shows many peaks that are essentially the same as the standard $2 \mathrm{M}$ muscovite mica, although the mica in the samples may not have exactly the same structure as that of common muscovite. The similarities of the XRD patterns of feldspars and micas make their study very difficult in these samples. The data given in tables 2 and 3 for mica also include counts produced from clay minerals, and the counts are affected by preferred orientation of the mica and clay.

Dolomite is present in most of the samples, and calcite occurs in a few samples, usually at the expense of dolomite (tahles 2 and 3 ).

Pyrite occurs in all of the samples, and traces of marcasite were detected in a few samples. The percentages reported (tables 2 and 3 ) are the sum of the two minerals. The value listed in the tables for most of the samples was calculated from the total sulfur concentration. These values provide the basis for a calibration curve (between the percentage of pyrito plus marca... site $\left(33.2^{\circ} 2 \theta\right)$ plus the height of marcasite $\left(52.0^{\circ} 20\right)$ ) from which the percentage could be determined for the remaining samples from observed XRD peak intensities.

XRD peaks at $9.4 \AA$ were observed in the two deepest samples (01KY12C1 and $13 \mathrm{C} 1$ ) from New Albany in the Kentucky core. This peak is indicative that basaluminite, ideally $\mathrm{Al}_{4} \mathrm{SO}_{4}(\mathrm{OH})_{10}: 5 \mathrm{H}_{2} \mathrm{O}$, is present in these samples (Hollingworth and Bannister, 19j0). Both of the samples also contain calcite which was not detected in any of the eamples from shallower depths in this core. The occurrence of basaluminite was previously reported in the lowermost part of the New Albany from outcrops, several miles to the south of the core location (Milton et al., 1955). They observed the mineral within a clayey residuum, which was interpreted as a zone of weathering. Our studies of the samples bearing basaluminite reveal no signs of weathering or residuum, but we do note that basaluminite is apparently confined to the calcitic Blocher Shale.

Other silt minerals occurring in trace amounts are zircon, amphibole, pyroxene, glauconite pellets (detected by microscopy), and marcasite (by XRD). Zircon, amphibole, and pyroxene grains are designated in tables 2 and 3 by "heavy miner." Siderite was not positively identified because the XRD data are 
indistinguishable from that of apatite in the samples. Small quantities of siderite may occur in certain types of synaeresis joints described below. Apatite XRD peaksare probably derived from the fossil fragments observed in the samples.

\section{Clay mineralogy}

The results of clay mineral analyses of the samples are given in tables 4 and 5. The results are given in parts in 10 of clay. The X-ray diffractometer method of analyses has a precision of only 10 to 20 percent because variations in the chemical composition affect the diffraction peak intensity. "Although.the results are semiquantitative, significant trends in relative abundances of the samples are clearly shown by the data. The clay minerals are calculated as a unit ignoring all non-clay minerals that may appear in the $<2$ $\mu \mathrm{m}$ fraction, such as quartz. The results of the clay analyses may not add up to exactly. 10 because the computations are only made to the nearest half part in 10 .

The samples from both cores are rich in illite clay and contain small amounts of mixed-structure clay. Chlorite is a major clay in the 0ill core and is only a minor-to-trace constituent in the $01 \mathrm{KY}$ core. The ratios of the peak counts/sec of the $7 \AA$ and $14 \AA$ spacings in chlorite from the 01IL core are listed in table 4. This ratio is a function of the relative amounts of iron and magnesium within the chlorite in the sample (the higher the ratio, the higher the iron/magnesium ratio). These ratios (table 4 ) indicate a general trend of decreasing iron and increasing magnesium content of the chlorite with depth in the Illinois core. No kaolinite was detected in any of the samples.

The main differences in the mineral composition of the two cores are: (1) chlorite is relatively abundant in the Illinois core; (2) dolomite and traces of siderite and/or apatite are more common in the Kentucky core than in the Illinois corc. The contrasting clay mineral compositions of the two cores are shown in figure 19.

Clay orientation index

The orientation index (tables 4 and 5) indicates how randomly the clay particles are oriented in the shale. A perfectly flocculated clay should have all, the clay minerals oriented in a completely random arrangement, and the .. orientation index would be 1.0. If some deflocculation takes place after sedimentation, some of the attractive forces between the particles will be weakened, and some of the repulsive forces will be increased. This action allows some of the plate-shaped particles to reorient more or less horizontally. The more nearly perfect the horizontal orientation, the more easily the shale splits along the bedding planes, and the larger will be the orientation index. The orientation index is a clue to the environments of deposition and early diagenesis.

In the 01IL samples the clay orientation index (fig. 20) is found to be relatively low, down to about the 1660-ft level, which indicates a low degree of parallel orientation of the clay platelets in these shales. This may 
TABLE 4-CLAY MINERALOGY AND ORIENTATION INDEX, SANGAMON COUNTY, TI.T.TNOTS, R.NRF, SAMPI.F.S (OITI.)

\begin{tabular}{|c|c|c|c|c|c|c|c|}
\hline \multirow{2}{*}{$\begin{array}{l}\text { Sample } \\
\text { number }\end{array}$} & \multirow{2}{*}{$\begin{array}{l}\text { Depth* } \\
\text { (ft) }\end{array}$} & \multicolumn{4}{|c|}{ Clay minerals $^{+}$(parts in 10 ) } & \multirow{2}{*}{$\begin{array}{c}\text { Chlorite } \\
\text { intensity } \\
\text { ratio, } 7 \AA / 14 \AA\end{array}$} & \multirow{2}{*}{$\begin{array}{l}\text { Clay } \\
\text { orientation } \\
\text { index }\end{array}$} \\
\hline & & Illite & Chlorite & Mixed & structure & & \\
\hline 01L2 & 1576.0 & 5 & 3.5 & & 2 & 2.7 & 1.0 \\
\hline 03LI & 1589.4 & 5 & 4 & & 1 & 3.5 & 1.7 \\
\hline $04 \mathrm{~L} 1$ & 1602.0 & 5.5 & 3.5 & & 0.5 & 3.7 & 1.7 \\
\hline $05 \mathrm{LI}$ & 1615.1 & 5.5 & 3.5 & & 1 & 3.4 & 1.3 \\
\hline $06 \mathrm{t}, 1$ & 1619.5 & 6 & 3.5 & & 0.5 & 3.7 & 2.0 \\
\hline $07 \mathrm{LI}$ & 1631.6 & 6 & 3.5 & & $0 . \overline{5}$ & 3.5 & 1.1 \\
\hline $09 \mathrm{~L} 1$ & 1647.4 & 5.5 & 3 & & 1.5 & 3.1 & 1.1 \\
\hline $09 \mathrm{~L} 2$ & 1656.2 & 7 & 3 & & $t$ & 3.3 & 1.4 \\
\hline $10 \mathrm{~L} 1$ & 1657.6 & 6.5 & 3 & & t & 2.8 & 1.0 \\
\hline $11 \mathrm{~L} 1$ & 1667.5 & 5.5 & 2.5 & & 2 & 2.8 & 2.0 \\
\hline $12 \mathrm{LI}$ & 1678.6 & 6.5 & 3 & & 1 & 3.0 & 2.4 \\
\hline $13 L 1$ & 1688.0 & 6 & 3 & & 1.5 & 3.6 & 3.7 \\
\hline $14 \mathrm{~L} 1$ & 1698.2 & 6.5 & 3 & & 1 & 3.2 & 2.0 \\
\hline 157.1 & 1710.0 & 6 & 2.5 & & 2 & 2.1 & 2.7 \\
\hline $16 \mathrm{~L} 1$ & 1723.4 & 7 & 3 & & $t$ & 2.8 & $1.9-2.2$ \\
\hline $17 \mathrm{~L} 1$ & 1730.6 & 7.5 & 2.5 & & 0.5 & 2.7 & 2.7 \\
\hline 19L1 & 1753.5 & 6.5 & 2 & & 1.5 & 2.3 & 5.3 \\
\hline 20L1 & 1763.3 & 6 & 2.5 & & 1.5 & 3.0 & 3.0 \\
\hline $21 \mathrm{I} .1$ & 1.776 .2 & 6 & 2.5 & & 1.5 & 3.2 & $2.4-3.2$ \\
\hline
\end{tabular}

*Depth below reference leve1 of 596 feet above MSL.

+ No kaolinite was detected in these samples.

@Function of the $\mathrm{Fe}$ to $\mathrm{Mg}$ ratio in the chlorice. 
TABLE 5-CLAY MINERALOGY AND ORIENTATION INDEX, CHRISTIAN COUNTY, KENTUCKY, CORE SAMPLES (OIKY)

\begin{tabular}{|c|c|c|c|c|c|}
\hline \multirow{2}{*}{$\begin{array}{l}\text { Sample } \\
\text { number }\end{array}$} & \multirow{2}{*}{$\begin{array}{l}\text { Depth* } \\
(f t)\end{array}$} & \multicolumn{3}{|c|}{ Clay Mineralst (parts in 10) } & \multirow{2}{*}{$\begin{array}{c}\text { Clay } \\
\text { orientation } \\
\text { index }\end{array}$} \\
\hline & & Illite & Chlorite & Mixed-structure & \\
\hline $01 \mathrm{Ll}$ & 2181.0 & 8.5 & nil & 1.5 & 2.4 \\
\hline 02L1 & 2188.6 & 6.0 & nil & 4.0 & 2.0 \\
\hline $03 \mathrm{LI}$ & 2216.7 & 6.5 & 1.5 & 2.0 & 2.2 \\
\hline $04 \mathrm{LL}$ & 2231.1 & 8.5 & nil & 1.5 & 2.0 \\
\hline 05L1 & 2244.1 & 9.5 & nil & 0.5 & 2.0 \\
\hline 06L1 & 2255.4 & 9.5 & nil & 0.5 & 1.8 \\
\hline $07 \mathrm{~L} 1$ & 2263.7 & 8.0 & nil & 2.0 & 1.8 \\
\hline $08 \mathrm{Cl}$ & 2270.3 & 8.0 & 0.5 & 1.0 & 2.7 \\
\hline $09 \mathrm{Cl}$ & 2280.0 & 8.0 & nil & 2.0 & 1.4 \\
\hline $10 \mathrm{Cl}$ & 2290.8 & 7.5 & niI & 2.5 & 1.7 \\
\hline $11 \mathrm{Cl}$ & 2299.8 & 8.0 & trace & 2.0 & 1.6 \\
\hline $12 \mathrm{Cl}$ & 2310.5 & 8.5 & nil & 1.5 & 2.5 \\
\hline $13 \mathrm{Cl}$ & 2318.8 & 7.5 & nil & 2.5 & 2.7 \\
\hline
\end{tabular}

*Depth below reference level of 548.0 feet above MSL.

+No kaolinite was detected in these samples. 


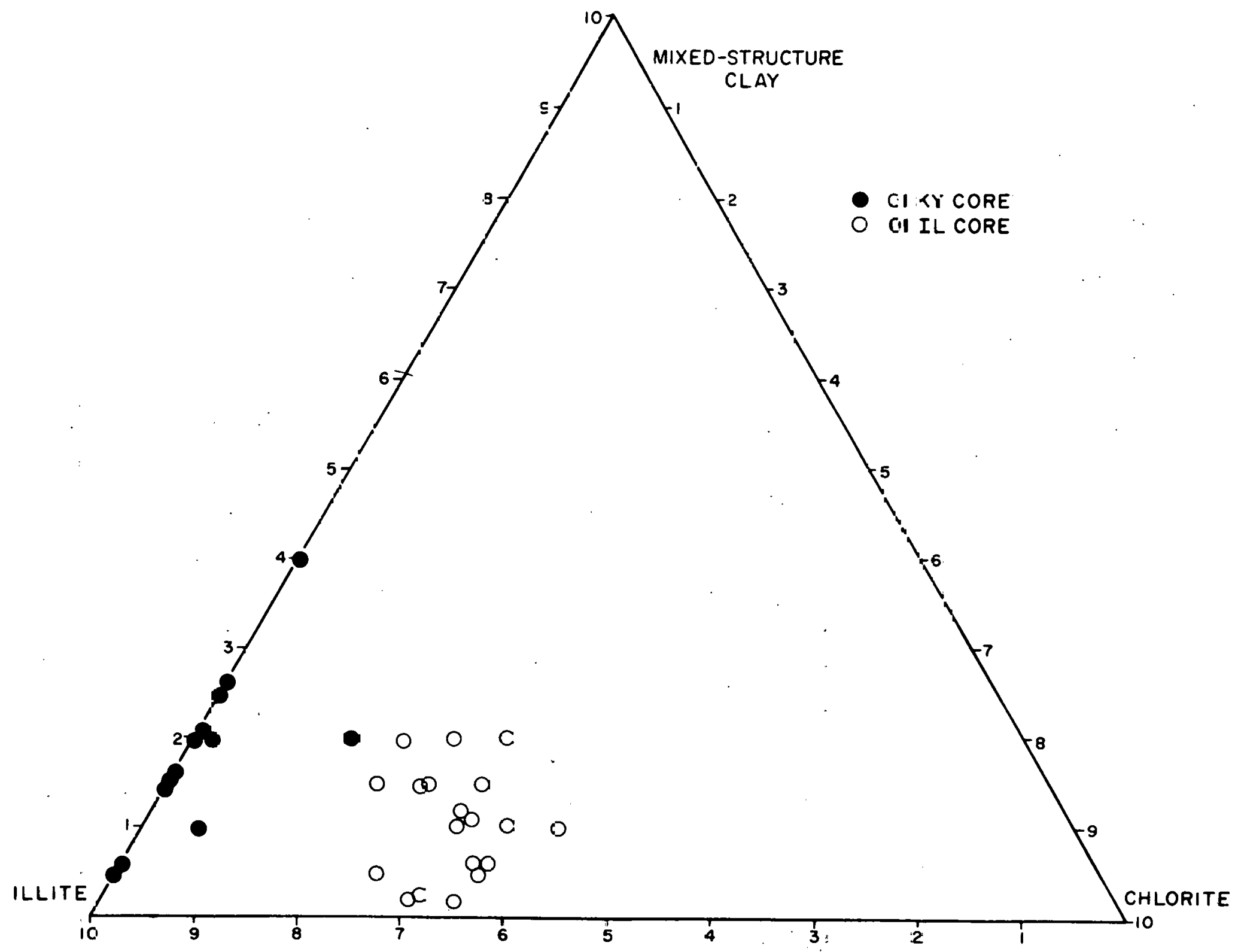

Fig. 19. Clay mineral composition of samples taken from the Kentucky and illinois cores. Raolinite was not detected in the samples. 


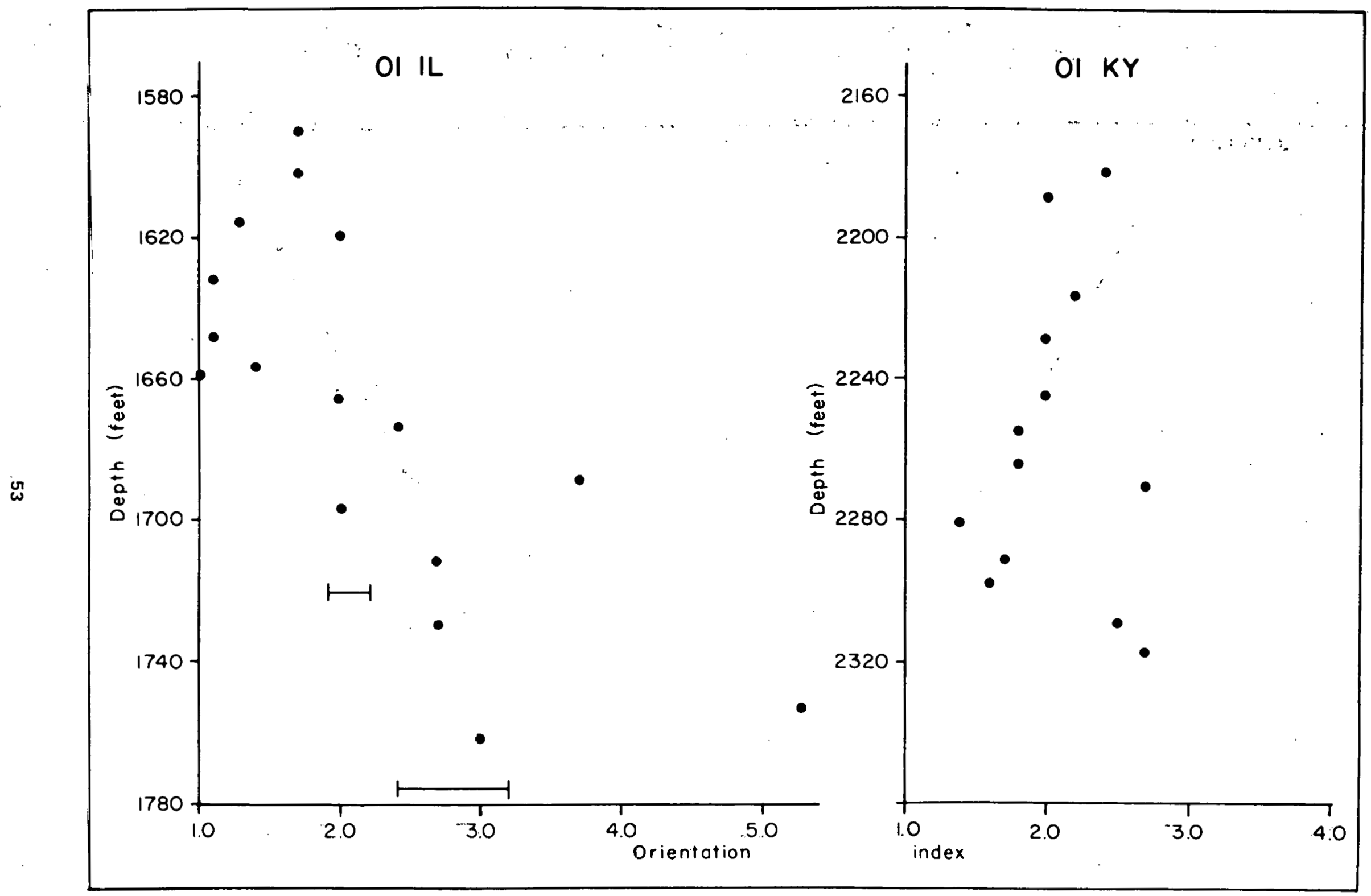

Fig. 20. Orientation index of the clay minerals in samples plotted against depth below reference of $596 \mathrm{ft}$ (01IL) and $548 \mathrm{ft}$ (01KY) above mean sea level. 
be due either to their being deposited in a flocculated condition or to extensive burrowing of the sediment by organisms. The lower part of the 01IL core generally has a high index, Indicating more preferred orientation of the platelets in the horizontal direction in this part of the New Albany.

In the OIKY samples the orientation indices generally show decreasing parallelism of the clay flakes with depth down to about the 2280-ft leve1 (fig. 20), where the trend appears to reverse.

\section{Petrography-Macrocharacterization}

The macroscopic characterizations of the samples from the 01IL core are listed in table 6 and from the $01 \mathrm{KY}$ core, in table 7 . Many of the specific characteristics listed in tables 2 and 3 are abbreviated or are listed in symbolic terms that are defined in the footnotes to table 6 . The data are based on visual studies, aided with a lU-power micruscupe, of slabo of the samples and on studies of the radiographs.

Most of the samples are strikingly laminated; the laminations vary in thickness from fine (up to $2 \mathrm{~mm}$ thick) to massive (more than $25 \mathrm{~mm}$ thick). The 01IL samples are more commonly massive, whereas the 01KY samples are predominantly laminated with thickness of laminae mainly less than $10 \mathrm{~mm}$.

Synaeresis jolnts are irregular polygonal systems of jolnts or cracks which have been filled with a secondary (dlagenetic) mineral. Synaeresis is a physico-chemlcal process in which the attractive forces between the particles of a suspension or gel are greater than the repulsive ones. This attraction between particles in the suspension produces tension in the particle network. As the chemical environment of the Inleistitial liquid changes, the relative strength of the attractive and repulsive forces between the particles changes, and cracks form in the sediment at or near the water interface.

In radiographs and in slabs of the rocks, synaeresis foints are recognized by thelr lineal [uiu and prodominant vertiral orientation; they cross only a few beds of shale. These joints strike in a random pattern in horizontal sections. We have recugulzed synacrcoie joints in 8 of the 16 samples of 01IL and in 16 of the 25 samples of 01KY (for example, see plate 3B). Most of the synaeresis joints are pyrite filled, rather short (about 5 to 10 $\mathrm{mm})$ and are crooked in vercteal section. Lcoo abundant are calcite-filled joints; these are much more planar in form and are longer than the pyritic joints. We suspect that some of the short, crooked ones contain siderite, but this has not been confirmed.

Most of the 01IL samples are dark greenish gray, but a few are olive black, brownish black, or grayish black; the 01KY samples are predominantly brownish black, but a few are olive gray, olive black, gray black, or black. Most of the 0lIL samples are strongly bioturbated, whereas bioturbation is rarely present in the $01 \mathrm{KY}$ samples. Pyrite nodules are generally absent or less than 5 in number in the 0IIL samples, whereas they are generally 5 to 25 in number in the $01 \mathrm{KY}$ samples. 
TABLE 6-PETROGRAPHY-MACROCHARACTERIZATION, SANGAMON COUNTY ILLINOIS CORE SAMPLES (OIIL)

\begin{tabular}{|c|c|c|c|c|c|c|c|c|c|c|c|c|}
\hline \multirow[b]{2}{*}{$\begin{array}{l}\text { Sample } \\
\text { number }\end{array}$} & \multirow[b]{2}{*}{$\begin{array}{l}\text { Depth* } \\
\text { (ft) }\end{array}$} & \multirow{2}{*}{\multicolumn{2}{|c|}{ Laminationst }} & \multirow{2}{*}{\multicolumn{2}{|c|}{ Synaeresis foints $\star \star$}} & \multirow[b]{2}{*}{ Color $\theta$} & \multirow[b]{2}{*}{ Bioturbation } & \multicolumn{3}{|c|}{ Pyrite nodulestt } & \multirow{2}{*}{$\begin{array}{l}\text { Other } \\
\text { sedimentary } \\
\text { features }\end{array}$} & \multirow{2}{*}{$\begin{array}{l}\text { Litho- } \\
\text { facies }\end{array}$} \\
\hline & & & & & & & & $\begin{array}{l}\text { Size } \\
\text { range (m) }\end{array}$ & Number & Occurrence & & \\
\hline 0ltL2 & 1576.0 & ms & pr & - & - & $5 \mathrm{CY} 4 / 1$ & very strong1y & - & & & - & I-B \\
\hline 0.311 & 1589.4 & ms & pr & - & few & SGY $4 / 1$ & very strongly & - & & & - & $I-B$ \\
\hline 0 iL1 & 1602.0 & $\mathrm{~ms}$ & pr & severa? & - & $\begin{array}{c}5 G Y 4 / 1 \& \\
5 Y 2 / 1\end{array}$ & very strongly & 2-16 & few & sc & - & I-B \\
\hline 05121 & 1615.1 & ms & pr & severai & - & $5 G Y 5 / 1$ & very strongly & $2-16$ & few & sc & - & I-B \\
\hline OGLI & 1619.5 & ms & $\mathrm{pr}$ & several & - & $5 G Y 4 / 1$ & very strongly & $<1-1$ & few & sc & - & I-B \\
\hline $0: L 1$ & 1631.6 & ms & $\mathrm{pr}$ & - & - & $5 G Y 4 / 1$ & very strongly & - & & & - & $I-B$ \\
\hline $0 ; L 2$ & 1633.6 & ms & pr & - & - & $\begin{array}{c}5 G Y 5 / 1 \\
5 Y 6 / 1\end{array}$ & completely & - & & & - & $\mathrm{I}-\mathrm{A}$ \\
\hline 09L1 & 1647.4 & ms & pr & few & - & $56 Y 4 / 1$ & very strongly & $2-4$ & several & sc & - & $\mathrm{I}-\mathrm{A}$ \\
\hline 09L2 & 1656.2 & ms & $\mathrm{fr}$ & few & - & $5 G Y 4 / 1$ & strongly & $2-4$ & few & sc & - & $\mathrm{I}-\mathrm{A}$ \\
\hline 12AI & 1678.6 & ms & Pr & few & few & SY $2 / 1$ & strongly & $2-4$ & few & bg & - & II $-A$ \\
\hline 1301 & 1688.0 & ms & fr $\& \mathrm{pr}$ & - & - & $5 Y 2 / 1$ & medium & $<1$ & several & bg & - & II-A \\
\hline $14 \mathrm{LI}$ & 1698.2 & cs & fr $\& p r$ & - & & $\begin{array}{c}5 Y R 2 / 1 \& \\
5 G Y 4 / 1\end{array}$ & weakly & $<1$ & several & bg & $\mathrm{b}$ & II-A \\
\hline $16 \mathrm{~L} 1$ & 1723.4 & fn \& med & fr. \& gd & - & - & N2 & - & $<1-16$ & few & bg & - & IV $-A$ \\
\hline $18: 1$ & 1740.2 & fn \& med & $f r \& g d$ & - & - & $5 Y R 2 / 1$ & - & $2-16$ & few & bg & - & $\mathrm{IV}-\mathrm{A}$ \\
\hline $19: 1$ & 1753.5 & med & $\mathrm{fr} \& \mathrm{gd}$ & - & - & N2 & - & - & & & - & IV $-\mathrm{A}$ \\
\hline $20 \div 1$ & 1763.3 & med \& ms & fr $\& g d$ & several & - & $\begin{array}{c}\text { SGYS/1 } \\
\text { SYR } 2 / 1\end{array}$ & very strongly & $2-16$ & few & $b_{B}$ & - & $I \& I I I-A$ \\
\hline
\end{tabular}

=Depth below reference level of $595.9 \mathrm{ft}$ above MSL.

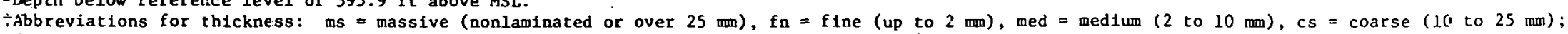

for contrast: pr $=$ poor, fr a falr, gd = good.

*Early stage joints are filled with pyrite anc/or siderite. Late stage joints are filled with calcite. Dash $(-)=$ not detected, few $=1$ tc 4 , several $=5$ to 25

Geological Society of America rock color chart: $N 1=$ black, $N 2=$ graylsh black, $5 Y R 2 / 1=$ brownish black, $5 Y 2 / 1=01$ ive black, $5 Y 4 / 1=0$ live gray, $5 Y 6 / 1=11 g h t$ olive gray, $5 G 44 / 1=$ dark greer.1sh gray, $56 Y 5 / 1=$ med dark greenish gray.

Hash $(-)=$ not de - ected, $f$ ew $=1$ to 4 , several $=5$ to $25, s c=$ scattered throughout, bg = only on bedding $p l a n e s$.

$\theta_{a}=$ pyrite veinlet ending in large pyrite nodule, $b=$ near vertical natural fracture, $c=$ large pyrite- $r$ ich area, $d=$ soft sediment deformation, $e=$ cut and fill siructuze, $f=$ cross lamina:ed silt layer. 
TAELE 7-PETF.CGRAPHY-MACROCHARACTERIZAT-ON, CHRISTIAN COUNTY. KENTUCKY CORE SAMPLES (O1KY)

\begin{tabular}{|c|c|c|c|c|c|c|c|c|c|c|c|c|}
\hline \multirow[b]{2}{*}{$\begin{array}{l}\text { Sample } \\
\text { number }\end{array}$} & \multirow[b]{2}{*}{$\begin{array}{l}\text { Depth* } \\
\text { (ft) }\end{array}$} & \multirow{2}{*}{\multicolumn{2}{|c|}{ Laminations }} & \multicolumn{2}{|c|}{ Synaeresis jolnts $\star \star$} & \multirow[b]{2}{*}{ Co:or" } & \multirow[b]{2}{*}{ Bloturbation } & \multicolumn{3}{|c|}{ Pyrite nodulestt } & \multirow{2}{*}{$\begin{array}{c}\text { Other } \\
\text { sedimentary } \\
\text { features }\end{array}$} & \multirow[b]{2}{*}{$\begin{array}{l}\text { Litho- } \\
\text { facies }\end{array}$} \\
\hline & & & & $\frac{\text { Synaeresi }}{\text { Early scage }}$ & $\frac{\text { joints*\#}}{\text { Late steg? }}$ & & & $\begin{array}{c}\text { Size } \\
\text { range (mon) }\end{array}$ & Yumber & Occurrence & & \\
\hline $01 \mathrm{Ll}$ & 2181.0 & $\mathbf{f a}$ & gd & - & - & N1 & - & $2-10$ & few & sc & - & IV-A \\
\hline 0101 & 2182.3 & fn & $g d$ & - & - & $5 Y R 2 / I$ & - & $1-25$ & few & bg & - & IV-A \\
\hline $02 \mathrm{~L} 1$ & 2188.6 & fn & $8 \mathrm{~d}$ & - & several & $5 Y 32 / 1$ & - & $<1-1$ & several & sc & - & IV-A \\
\hline $02 \mathrm{Cl}$ & 2191.2 & fn & gd & - & - & $5 Y 32 / 1$ & - & $1-20$ & several & b8 & a & IV-B \\
\hline $03 \mathrm{LI}$ & 2216.7 & fo \& med & fr & few & few & $5 Y 32 / 1$ & - & $<1-8$ & several & bg & - & IV-B \\
\hline $03 \mathrm{Cl}$ & 2220.3 & $\mathrm{fn}$ & $\mathrm{fr}$ & fev & few & $5 Y R 2 / 1$ & - & $<1-20$ & several & bg & b & IV-B \\
\hline $04 \mathrm{Cl}$ & 2230.2 & ms & $\mathrm{fr}$ & seineral & - & $\begin{array}{l}5 Y R 2 / 1 \\
\& 5 Y 4 / 1\end{array}$ & medium & $<1-16$ & several & sc $\approx b g$ & b & II-B \\
\hline $04 \mathrm{LI}$ & 2231.1 & fo \& med & $\mathrm{fr}$ & - & - & $5 \mathrm{YR} 2 / 1$ & sporad1c? & $1 \div 4$ & several & bg & - & III-A \\
\hline $05 \mathrm{Cl}$ & 2240.1 & fo \& cs & fr \& $p r$ & fex & few & $5 \mathrm{YR} 2 / 1$ & - & $2-16$ & several & bg & c & IV-B \\
\hline $05 \mathrm{~L} 1$ & 2244.1 & med & $\mathrm{fr}$ & - & - & $5 \mathrm{YR} 2 / 1$ & - & $1-2$ & several & bg & - & $I V-B$ \\
\hline $06 \mathrm{Cl}$ & 2250.0 & $\mathrm{~ms}$ & fr & abcind & - & $5 Y 4 / 1$ & strongly & $1-4$ & several & sc & - & II-B \\
\hline $06 \mathrm{L1}$ & 2255.4 & ms & $\mathrm{fr}$ & abund & - & $5: 4 / 1$ & strongly & $1-8$ & several. & sc & - & II-B \\
\hline $07 \mathrm{Cl}$ & 2260.3 & fn $\&$ med & $\mathbf{f r}$ & few & - & $5 \mathrm{SR} 2 / 1$ & - & $1-20$ & several & bg & - & IV-B \\
\hline $07 \mathrm{~L} 1$ & 2263.7 & fa $\& \mathrm{cs}$ & $\mathrm{fr} \& \mathrm{pr}$ & - & few & $\begin{array}{l}\text { 5YR2/1 } \\
\varepsilon \times N 1\end{array}$ & - & $1-8$ & several & bg & d & III-A \\
\hline $08 \mathrm{C} 1$ & 2270.3 & med \& cs & $\mathrm{fr}$ & several & - & $5: R 2 / 1$ & sporadic & $1-4$ & several & bg \& sc & e & III-A \\
\hline OBL1 & 2273.5 & fn & pr & at end & - & $\mathrm{N} 2$ & sporadic & $1-4$ & abund & sc & b & III-B \\
\hline $09 \mathrm{Cl}$ & $2280 . \mathrm{C}$ & med $\&$ cs & gd & seteraI & Eew & $5: \mathrm{R} 2 / 1$ & sporadic? & $1-4$ & several & sc & - & III $-A$ \\
\hline 1021 & $2287 . \varepsilon$ & med & $\mathbf{f r}$ & fev & few & $5 \div R 2 / 1$ & - & $1-4$ & severaf & bg & - & IV-B \\
\hline $10 \mathrm{C} 1$ & 2290.8 & fa $\delta$ med & $\mathrm{fr}$ & $a b i n c d$ & - & $5 \div 2 / 1$ & - & $1-4$ & abund & bg & - & III-B \\
\hline $11 \mathrm{LI}$ & 2293.0 & fn \& ms & $p r \& g d$ & $a b$ snd & - & $5 \operatorname{TR} 2 / 1$ & - & $1-4$ & abund & sc $\& b g$ & - & III-B \\
\hline $11 \mathrm{Cl}$ & 2299.8 & fis \& cs & gd. & fes & - & $5 \mathrm{RR} 2 / 1$ & - & $1-4$ & several & bg & e \& $f$ & IV-B \\
\hline $12 \mathrm{Cl}$ & 2310.5 & fn \& med & $p r \& g d$ & - & - & $5 \mathrm{YR} 2 / 1$ & - & $1-4$ & several & bg & - & IV-B \\
\hline $12 \mathrm{~L} 1$ & $2311 . i$ & fn & $\operatorname{fr}$ & - & - & 5 YR2/1 & $-\because \cdot$ & $1-4$ & severa: & bg & - & IV-B \\
\hline $13 \mathrm{Ll}$ & 2312.7 & fn o wed & $\mathrm{pr}_{\delta} \mathrm{gd}$ & - & - & $5 \mathrm{YR} 2 / 1$ & - & $1-4$ & severa: & $b_{B}$ & - & IV-B \\
\hline $13 \mathrm{Cl}$ & 2318.8 & fn med & $\mathrm{pr} \& \mathrm{fr}$ & - & $\dot{-}$ & N2 & - & $1-22$ & few & bg & $\mathrm{f}$ & IV-B \\
\hline
\end{tabular}

*Depth below reference level of $548.0 \mathrm{ft}$ above MSL. All other footnotes are given 1n footnotes to Tabie 2. 


\section{Petrography-Microcharacterization}

\section{Texture and structure}

In addition to the mineralogical composition of the shale samples discussed previously, a number of prominent features can be described using a petrographic microscope, foremost of which is the distribution of the various silt components in the shale. Typically, most of the silt is randomly dispersed through the shale. In the laminated lithologies, thin silt laminae are common (plate 1A). These laminae range in thickness from a few silt grains to several millimeters. Most of the laminations are continuous, even, and parallel,,although minor disruptions and lenticular laminae are also present. The thicker silt layers sometimes are very faintly cross-bedded and may have a wavy upper surface suggestive of low-amplitude ripples.

The nonlaminated lithologies commonly have concentrations of silt within burrows (plate 1B, C). These concentrations may be the result of particle size selection by the organism which was feeding on the sediment.

The average and maximum sizes of quartz grains (viewed in thin section) are recorded as a rough measure of current velocities. Quartz grain size is quite uniform in both of the cores studied and averages about $25 \mu \mathrm{m}$ (maximum about $50 \mu \mathrm{m}$ ). Most grains are subangular to subrounded, as would be expected at these grain sizes (no significant abrasional rounding occurs at diameters below about $50 \mu \mathrm{m}$ ). One unusual occurrence of rounded silt grains segregated within a burrow fill is illustrated in plate $1 \mathrm{C}$.

\section{$\underline{\text { Paleontology }}$}

A variety of microfossils and fossil fragments are present in the shale and can be identified in thin section. Spores are the only abundant fossil and two different types usually occur together: one thickwalled and the other thin-walled (plate 1D). Spores are found in virtually all samples of the brownish-black shales. Conodonts, phosphatic fish scales, and inarticulate brachiopod fragments (plate 1E) are rare components of the shale but occur in great numbers in some samples (01KY03C1, 01KY05C1, 01KY07L1, 01KY08C1, 01KY09C1, 01KY11C1, 01KY12C1, 01IL07L1, 01IL07L2, 01IL08L1, 01IL09L2). A variety of macerals, or plant-derived fragments other than spores, occur abundantly dispersed in the brownish-black shales. They are commonly about $5 \mu \mathrm{m}$ in size and consist mainly of undifferentiated liptinite, some vitrinite, and a few inertinite particles.

Calcareous microfossils approximately 100 to $300 \mu \mathrm{m}$ in diameter were found in thin sections of sample 01KY03L1. These micrufossils are tentatively identified as calcispheres of the genus Radiina (Reitlinger, 1957) (identification by R. M. Cluff and J. W. Baxter). This is the Cirst reported occurrence of these microfossils outside the Russian Platform.

The calcispheres in the New Albany lie in several thin laminae of silicified spores and microfossils. Each sphere consists of a perforate inner sphere, numerous thin radiating spokes, and a thin outer sphere that is rarely 


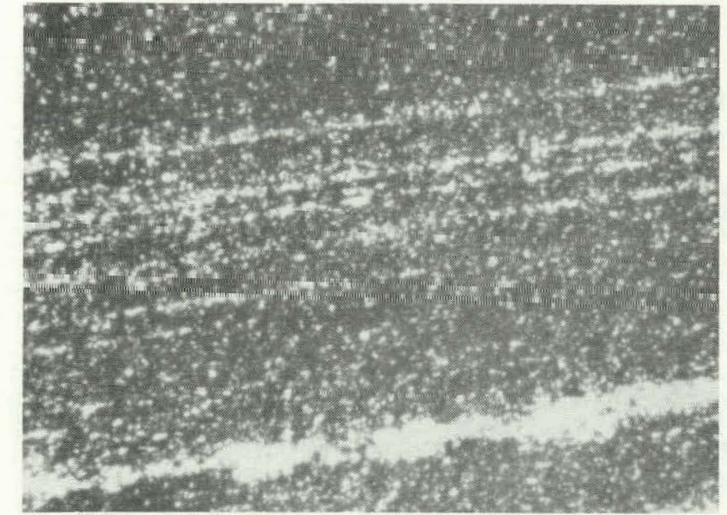

A

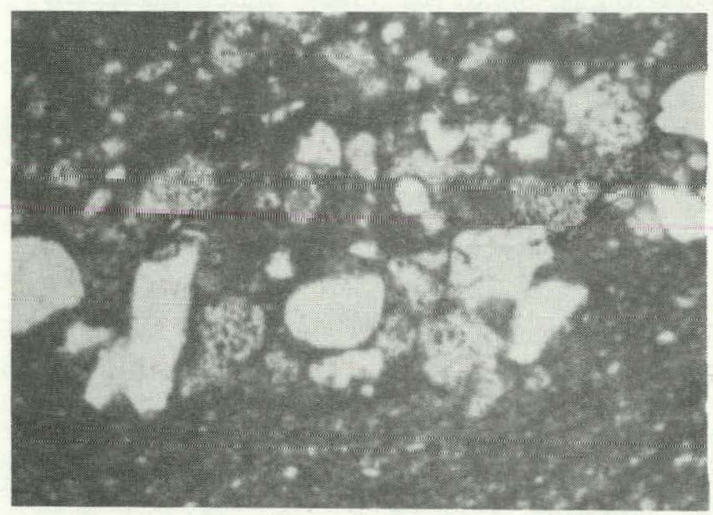

C

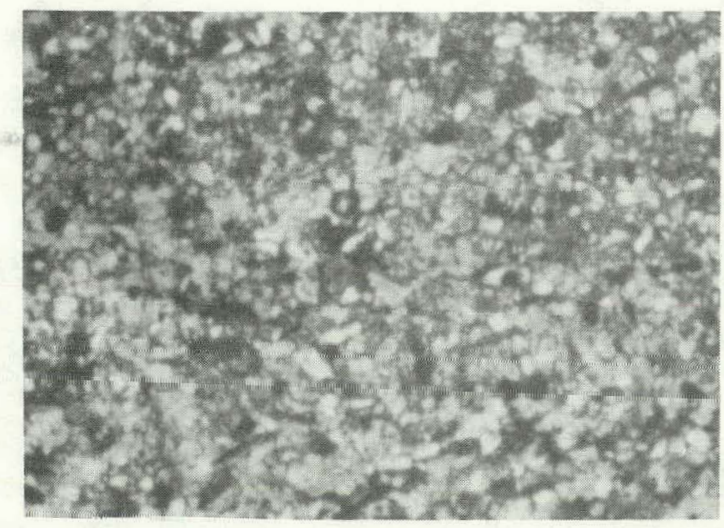

$E$

$1 / 2 \mathrm{~mm}$

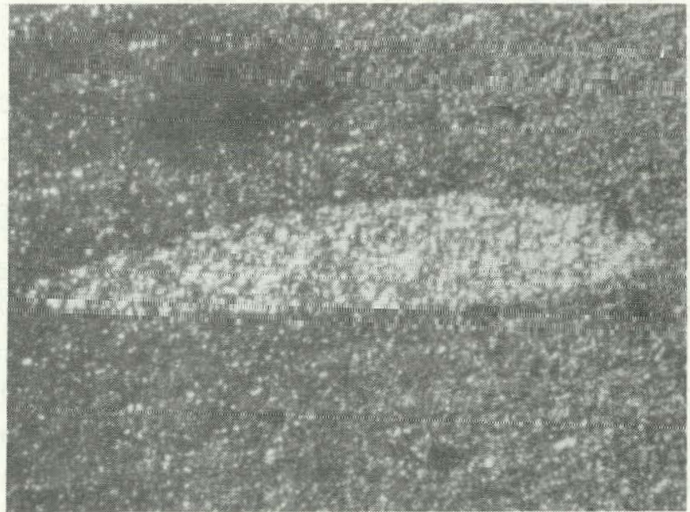

B

$\mathrm{mm}$

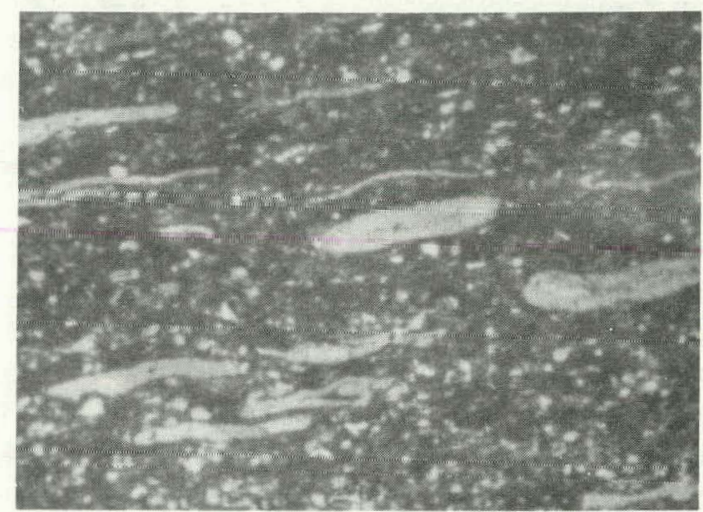

D

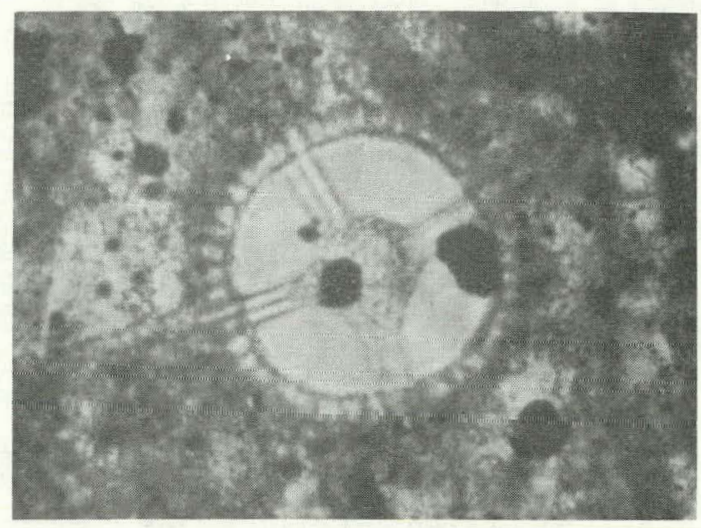

$\mathrm{F}$

PLATE 1. (A) Fine silt laminae in brownish-black shale. Sample 01KY08C1.

Compressed burrow with silt-rich filling. Clay is well oriented in area surrounding but poorly oriented within burrow. Sample 01KY08C1. (C) Rounded fine sand grains concentrated within a burrow filling. Sample 01KY08C1. (D) Flattened spores. Note the difference between thin-walled and thick-walled types. Sample 1KY03L1. (E) Several phosphatic fossil fragments scattered in a silt layer. The fragments are shown here as needle-shaped, about 0.1 to $0.2 \mathrm{~mm}$ long, and oriented more or less NE-to-SW on this micrograph. Sample 01KY07L1. (F) Calcisphere (probably Radiina Reitlinger). Note the inner perforate capsule and the thick spines projecting from the outer wa1l, and the pyrite grains (black) within and around the calisphere. Sample 01KY03Ll. 
preserved (see plate 1F). The space between the inner and outer spheres and between the spokes is filled with a poorly crystallized radial-fibrous silica cement. A euhedral pyrite crystal commonly occupies the center of the sphere and may obliterate part or all of the microfossil structure. Numerous spores in the laminae containing these spheres are also silica-filled and are preserved uncompressed.

The carbonate which makes up the calcispheres is unusually pleochroic and stands out distinctly in thin section, even when fragmented. Many of the smaller carbonate grains in the surrounding shale matrix appear to be the same material, which suggests that at least some proportion of the carbonate in the shale is organic in origin. Sample OlKYO2Ll contains several laminae of silicified spheres similar to those surrounding the calcispheres, but no skeletal structures are preserved, and it cannot be proven that these were also calcispheres.

Outcrop samples from the uppermost member of the New Albany from north-central Kentucky, collected by Christine Griffith (University of Wisconsin, Madison), were studied by Robert Cluff. Numerous poorly preserved calcispheres, also probably of the genus Radiina, are present in these samples. The calcispheres in the Christian County core are also apparently restricted to the uppermost portion of the shale, suggesting that these microfossils may prove to have stratigraphic significance. Very little is known about the paleoecology of calcispheres, and their relationship to the depositional environment of the shale is at present unknown.

\section{Diagenetic features}

A variety of diagenetic features are characterized by thin section analysis. Several forms of diagenetic pyrite are commonly observed:

(1) Framboidal pyrite-F1ne $(<20 \mu \mathrm{m})$, randomly dispersed, spherical framboids are the most common form of pyrite in the organic rich shales.

(2) Euhedral crystals-Euhedral to subhedral grains of pyrite occasionally are found within microfossils (see plate 1F) and other voids in the rock. They range from 20 to over $100 \mu \mathrm{m}$ in diameter and are primarily void filling, although in some instances they disrupt the feature(s) surrounding them.

(3) Patches-Clumps of individual framboids or subhedral grains, sometimes filling burrows and sometimes lying along thin pyritic laminae.

(4) Void fillings-Massive pyrite fillings of the space between sand and silt grains in laminae; interiors of spores and synaeresis joints. Filled spores are commonly preserved uncompressed, while synaeresis joint fillings are often deformed and folded by compaction.

(5) Nodules-Nodules range widely in size, from a few millimeters to over $2 \mathrm{~cm}$ in diameter. They are usually flattened parallel to bedding and are roughly circular in the horizontal plane. Large nodules usually occur alone. whereas smaller nodules may be very abundant and are closely spaced along bedding planes. 
The deformation of silt laminae around pyrite nodules and the preservation of uncompressed spores with pyrite fillings indicate that pyritization is an early diagenetic event which occurred before significant lithification and compaction of the sediment.

Fine grained, sparry carbonate cements are cummun as interparticlc fillings in silt laminae and as intraparticle fillings in fossils. Micritic (calcite) shales in the upper part of the "Glen Park" Formation (samples 01IL07L1 and 07L2) display neomorphic growth of microspar. Brachiopod shells and other fossil fragments are rarely preserved intact, but instead are usually replaced by sparry carbonate. Calcite-lined vugs are present near the base of the New Albany Shale in the 04IL core, but were not noted in either the $01 \mathrm{KY}$ or OlIL cores. The majority of the dolomite observed in these two cores is usually present as silt-sized rhombs which are randomly scattered through the shale or concentrated along thin laminae. Their distribution along laminae suggests that the dolomite is largely detrital, and not diagenctic.

Other diagenetic feacuses die vicasionally noted. Microfossils in samples 01KY02L1 and 01KY04L1 are f1lled with a poorly-crystallized, radialfibrous, chalcedony cement. Pressure solution of silt grains is usually very minor and restricted to coarser silt and fine-sand laminae. Compaction effects, such as crushed spores and deformed synaeresis joints, are visible in all samples.

\section{Particle orientation}

Oriented horizontal thin sections were prepared from the OlKY samples and examined for possible directional properties and paleocurrent indications. Generally, few elongate particles suitable for measurement were present within the area of a standard 1 in. $x 2$ in. petrographic slide. Whère several such particles were found, the measured orfentations were almost totally random. This may indicate that borcom curleuls serving to oricnt the partirles were absent, or that shifting botrom curreuls oriented thc particles in several directions. Because of these results, further lhin-section anulyses in the horizontal plane were judged not worth the effort involved, and the practice of routinely making horizontal thin sections has been discontinued. Instead, only those samples that show some promise of yielding significant data (based on examination of the core and radiographs) will have horizontal sections cut.

\section{Dispersed organic matter and vitrinite reflectance}

The organic mater 1n the samples is dispericd among the inorganir. mineral grains, and when it is moderately abundant, it gives the shale its black color. The solid organic matter takes two forms: (1) amorphous, sapropelic film that coats the surfaces of the mineral grains and more or less acts as a matrix material; and (2) discrete particles of plant-derived particles that are of several different types or nacerals (a term for orgalic particles analogous to minerals for inorganic particles). The most abundant type of maceral in the samples studied is sporinite, the disc-shaped spores which were described above (Petrography-Microcharacterization). The spores 
are commonly about $20 \mu \mathrm{m}$ in diameter, and they fluoresce a characteristic yellow when examined microscopically with blue light (xenon lamp).

The maceral vitrinite, which is derived from woody plant tissues, occurs as fine, silt-sized particles, widely dispersed in the shales. Microscopic studies of vitrinite in the samples require acid dissolution of the minerals with $\mathrm{HF}$ and $\mathrm{HCl}$ to concentrate the insoluble organic particles (fig. 18). Vitrinite particles are only a minor component of the organic matter in the samples; they occur in all samples of the black shales, but are virtually absent in some of the greenish gray shales.

Traces of inertinite macerals were observed in most of the samples studied, but their fine size prevented more detailed identification of the types of inertinite that occur.

The reflectance of macerals in coal and other sediments has been recognized as a guide to the degree of thermal metamorphism or rank of the coal, and the correlation with metamorphism is best exhibited by the reflectance of vitrinite. Reflectance values are reported as percentage of reflectance under oil immersion (\% Ro), compared to reference glass standards of known reflectance. The averages of the reflectances of randomly oriented vitrinite measured on polished surfaces using an oil immersion lens are listed in tables 8 and 9 along with the number of particles measured and the standard deviation of the measurements. The averages range from 0.33 percent (01KY03C1) to 0.82 percent (01KY4C1), with a majority falling between 0.35 and 0.60 percent. Three samples (01KY04C1, $01 \mathrm{KY} 12 \mathrm{Cl}$, and $01 \mathrm{KY} 13 \mathrm{Cl}$ ) have such large standard deviations that they should not be considered in evaluating the overall formation. The reason for the wide variation in reflectance values for these samples is not yet known. Samples with fewer than 25 readings should be considered only approximate indicators of the reflectance at that leve1. Fifty readings are considered an adequate sampling. Average reflectance values, such as these, are slightly lower than the maximum reflectance measurements taken during $360^{\circ}$ rotation of the particle. The difference between these two methods of measurement is significant only at reflectance levels higher than the average reported here.

The average reflectance values for the Kentucky core are near 0.5 percent, whereas those for the Illinois core are near 0.4 percent. The data for each core are shown plotted against depth in figures 21 and 22 . The absence of a reflectance gradient with depth implies that the geothermal gradient in these two areas was fairly low. The reflectance values observed in these cores correspond to a level of organic metamorphism of about 5 to 8 (LOM scale of Hood et al., 1975). Hood et al. (1975) indicate that this range corresponds to the immature stage of early methane generation, resulting from biologic degradation and low-temperature processes, and is transitional to the mature stage wherein Staplin (1977) reports that oil and some wet gas way occur. The main phase of gas generation occurs at LOM values of 12 to 14, corresponding to vitrinite reflectance of 1.4 to 2.1 percent (fig. 23).

\section{DISCUSSION OF RESULTS}

\section{Mineralogy}

Analyses of the clay mineralogy are complete on too few locations within the Illinois Basin, and the stratigraphic correlations between the two 
TABLE 8-VITRINITE REFLECTANCE, SANGAMON COUNTY, ILLINOIS, CORE SAMPLES (O1IL)

\begin{tabular}{lcccc}
\hline Sample & Depth (ft) & \# Readings & $\begin{array}{c}\text { Ro }(\%) \\
\text { Average }\end{array}$ & Std. deviation \\
\hline $01 \mathrm{~L} 2$ & 1576 & 15 & 0.43 & 0.06 \\
$04 \mathrm{~L} 1$ & 1602 & $1 /$ & 0.46 & 0.13 \\
$09 \mathrm{~L} 1$ & 1647 & no vitrinite & - & - \\
$10 \mathrm{~L} 1$ & 1657 & 6 & 0.49 & 0.11 \\
$11 \mathrm{~L} 1$ & 1667 & 40 & 0.39 & 0.10 \\
$14 \mathrm{~L} 1$ & 1698 & 43 & 0.40 & 0.11 \\
$16 \mathrm{~L} 1$ & 1723 & 48 & 0.41 & 0.09 \\
$17 \mathrm{~L} 1$ & 1730 & 50 & 0.37 & 0.13 \\
$19 \mathrm{~L} 1$ & 1753 & 50 & 0.40 & 0.11 \\
$21 \mathrm{Ll}$ & 1776 & 23 & 0.38 & 0.05 \\
\hline
\end{tabular}

*Depth below reference level of $596 \mathrm{ft}$ above MSL. 
TABLE 9-VITRINITE REFLECTANCE, CHRISTIAN COUNTY, KENTUCKY, CORE SAMPLES (OIKY)

\begin{tabular}{|c|c|c|c|c|c|}
\hline Sample & Depth $(f t) *$ & $\#$ & Readings & $\begin{array}{l}\text { Ro }(\%) \\
\text { Average }\end{array}$ & Std. deviation \\
\hline $01 L 1$ & 2181 & & 35 & 0.46 & 0.05 \\
\hline $01 C 1$ & 2182 & & 59 & 0.39 & 0.08 \\
\hline $02 \mathrm{~L} 1$ & 2189 & & 50 & 0.48 & 0.09 \\
\hline $02 \mathrm{C} 1$ & 2191 & & 27 & 0.36 & 0.10 \\
\hline 03L1 & 2217 & & 36 & 0.46 & 0.09 \\
\hline $03 \mathrm{C} 1$ & 2220 & & 32 & 0.33 & 0.11 \\
\hline $04 \mathrm{Cl}$ & 2230 & & 49 & 0.82 & 0.30 \\
\hline $04 \mathrm{Ll}$ & 2231 & & 50 & 0.53 & 0.11 \\
\hline $05 \mathrm{C} 1$ & 2240 & & 33 & 0.41 & 0.08 \\
\hline $05 \mathrm{LI}$ & 2244 & & 48 & 0.58 & 0.11 \\
\hline $06 \mathrm{C} 1$ & 2250 & no & vitrinite & - & - \\
\hline $06 \mathrm{Ll}$ & 2256 & no & vitrinite & - & - \\
\hline $07 \mathrm{Cl}$ & 2260 & & 62 & 0.39 & 0.06 \\
\hline $07 \mathrm{~L} 1$ & 2264 & & 12 & 0.37 & 0.05 \\
\hline $08 \mathrm{C} \cdot 1$ & 2270 & & 44 & 0.52 & 0.07 \\
\hline $08 \mathrm{~L} 1$ & 2274 & & 23 & 0.44 & 0.04 \\
\hline 0901 & 2280 & & 43 & 0.55 & 0.10 \\
\hline 10L1 & 2288 & & 16 & 0.48 & 0.07 \\
\hline $10 \mathrm{Cl}$ & 2291 & & 32 & 0.52 & 0.11 \\
\hline $11 \mathrm{Cl}$ & 2293 & & 24 & 0.51 & 0.08 \\
\hline $11 C 1$ & 2300 & & 16 & 0.44 & 0.10 \\
\hline $12 \mathrm{Cl}$ & 2310 & & 23 & 0.79 & 0.36 \\
\hline 12L1 & 2311 & & 27 & 0.60 & 0.14 \\
\hline $13 \mathrm{~L} 1$ & 2313 & & 21 & 0.53 & 0.12 \\
\hline $13 \mathrm{Cl}$ & 2319 & & 17 & 0.51 & 0.28 \\
\hline
\end{tabular}

*Depth below reference level of 548 feet above MSL. 


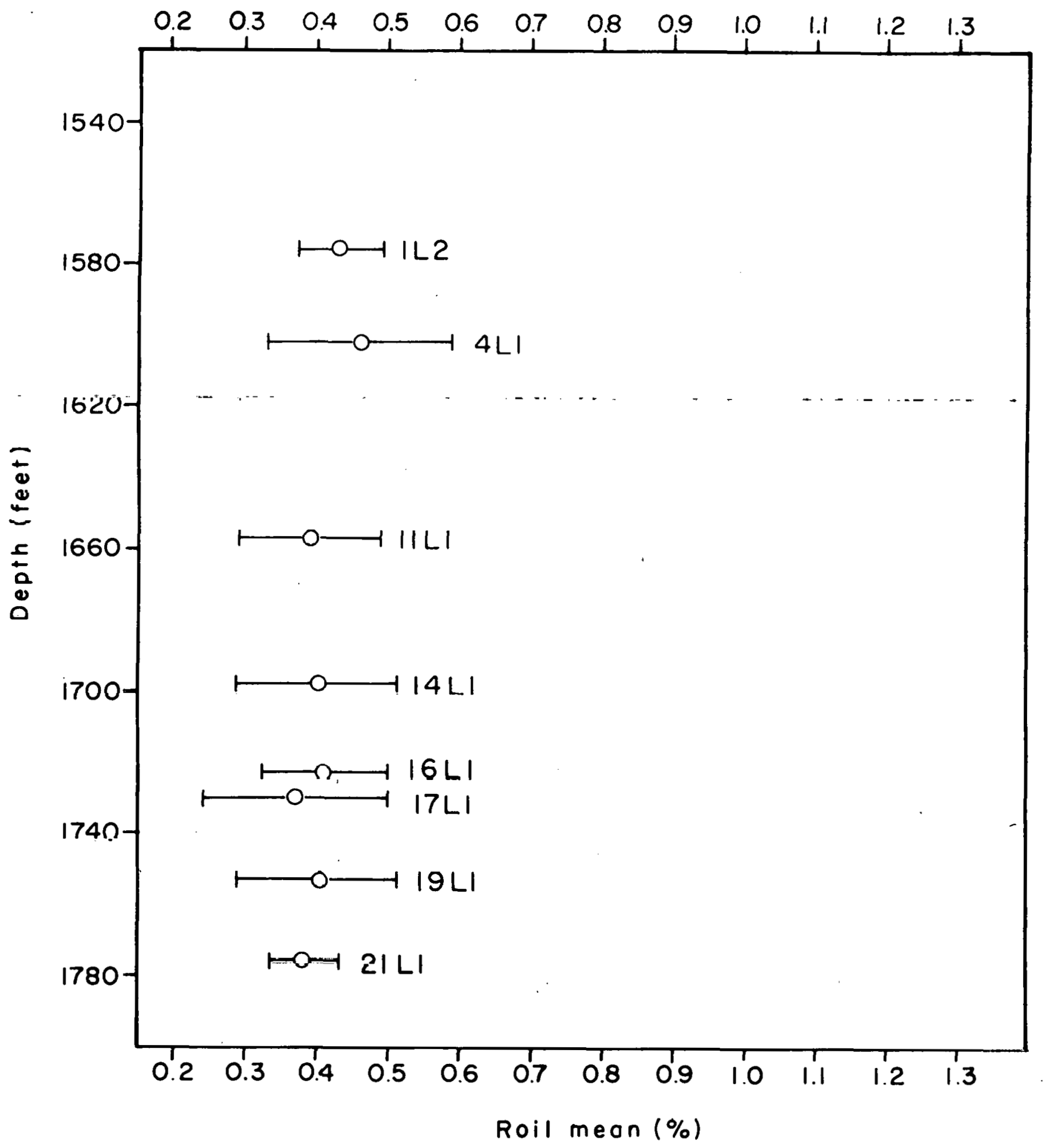

Fig. 21. Mean-random vitrinite reflectance, in oil, Sangamon County, Illinois, samples (0IIL). Error bars correspond to \pm one standard deviation. Depths are below reference level of $596 \mathrm{ft}$ above mean sea level. 


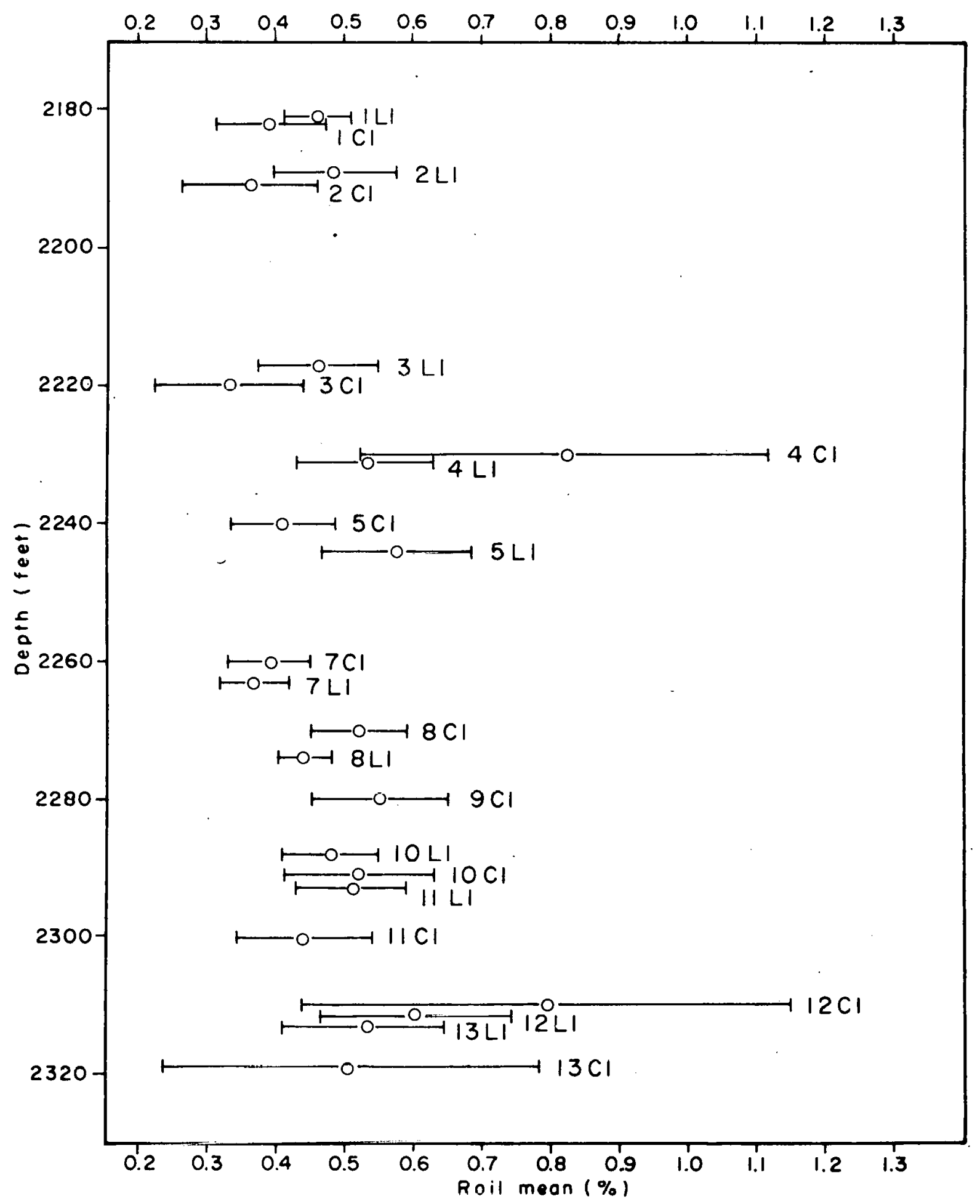

Fig. 22. Mean-random vitrinite reflectance, in oil, Christian County, Kentucky samples (01KY). Error bars correspond to \pm one standard deviation. Depths are below reference level of $548 \mathrm{ft}$ above mean sea level. 


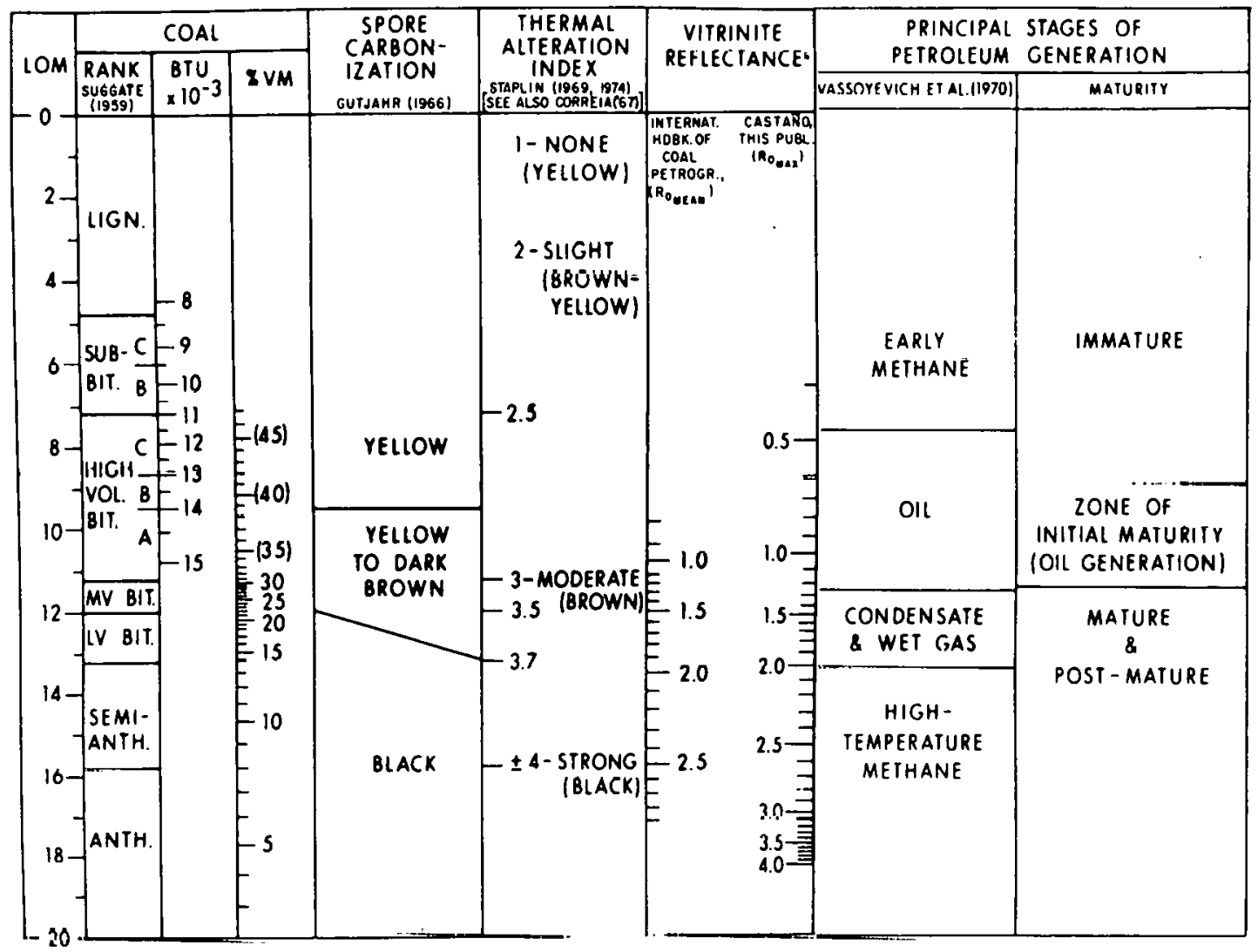

Fig. 23. Relation of level of organic metamorphism (LOM), coal rank, various measures of rank in sediments, and the principal stages of oil and gas generation. (Áfer houd el al., 1975): 
cores studied are too little known to draw conclusions regarding the direction of sediment transport as was proposed by Parham $(1962,1966)$. However, the absence of kaolinite suggests that either the shales were deposited at some considerable distance from the shoreline or some of the feldspar and/or mica occurring in the samples are alteration products from kaolinite that might have been deposited in the original sediment. The first interpretation is favored because of the fine grain size and the absence of significant authigenic silicate minerals in the samples studied. According to the trends observed by Parham (1966), the relative abundance of chlorite in the samples studied suggests that the Kentucky location was nearer the shoreline than was the Illinois location during New Albany deposition.

The abundance, 2.5 parts and above, of mixed-structure clays in three of the 0IKY samples might be due to the abundance of organic matter in these samples. If organic matter were absorbed on the surface of these small clay crystals, they would not be able to incorporate $\mathrm{K}$ or $\mathrm{MgOH}$ into their crystal structure as needed to form illite or chlorite respectively.

\section{Petrography}

The concept of petrographic lithofacies and its application to shales

Sedimentary petrographers have used the microfacies concept (i.e., Textoris and Carozzi, 1964) for many years as a method of characterizing subtle variations in the fabric and the composition of sandstones and carbonate rocks. This concept has proven to be extremely valuable in interpreting the depositional and diagenetic history of these rock types, but the difficulties of the microscopic study of shales in thin section have largely prevented its application to shales. This study presents an opportunity to apply this concept to the study of shales by using a wide variety of methods of analysis. The variations in mineralogic and petrographic characteristics of the samples studied permit their subdivisions into several distinctive lithologies. Since the term microfacies most strictly applies to lithologies defined on the basis of thin-section petrography, we prefer to use the more general term "lithofacies" in this report.

Studies of sedimentary fabrics in recent muds from various depositional settings (Moore and Scruton, 1957) and the interrelationships between organisms and muddy substrates (Khoads, 1974) have greatly increased our understanding of small-scale structures in mudrocks. These studies and others have established several factors that control the nature of the sediment deposited in a wide variety of environments. These factors are: (1) sediment source; (2) physical process of deposition; (3) rate of deposition; and (4) reworking by sediment-ingesting organisms. The last is, in turn, controlled by a number of other conditions, such as oxygen content and salinity of the water.

The separation of shales into lithofacies defined on the basis of texture, small-scale sedimentary structures, and biogenic structures has the potential of revealing subtle changes in oxygenation, current activity, and depth of the waters in which the rocks were deposited. Further separation by mineralogical composition and diagenetic structures (such as synaeresis joints) way leved differences in the source area and early burial history of the 
sediment. Because the relations between physical and biogenic sedimentary structures and the environment of deposition are generally better understood than the controls on physical and chemical properties, this approach may provide new insights on those controls.

\section{Lithofacies of the New Albany}

The shale 1ithofacies defined in this paper were chosen by characterizing seven basic properties (table 10). The color of the rock and the degree of lamination form the backbone of the classification, defining four broad 1ithologies (types I, II, III, and IV). Each 1ithology has been divided into two subcategoreis on the basis of synaeresis, degree of bioturbation, form and distribution of pyrite, silt content and mineralogy, and the abundance of spores. The samples studied are identified as lo lithofacies in the last column in tables 6 and 7 .

Because at this time only about 40 samples from two cores have been examined, it is almost certain that not all of the lithofacies present in the shales of the New Albany have been observed, nor perhaps have a11 of the features that may prove useful in defining lithofacies been recognized. Furthermore, it is recognized that the characteristics chosen to define lithofacies, and the 1ithofacies themselves, are partly subjective and depend upon the techniques that are used to study the shale. An example of this is the extensive development of synaeresis fractures observed in many samples, which we judged important enough to warrant their separation into distinct lithotypes. The recognition of extensive synaeresis is dependent upon routine radiography of the core samples; many synaeresis joints are invisible on the core itself and they are not very striking in thin section. .

\section{Lithofacies I: Bioturbate greenish-gray mudstones}

Litlufacies $I$ is characteriscd by oxtensive binturbation, hy an absence of laminations and other primary sedimentary structures, and by its very light color. Plate 2 illustrates the swirling texture, which is the result of sediment mixing by burrowing organisms. Distinct burrows are not visible on this radiograph, because the compositional difference between burrow filling and matrix is very slight. Burrows can be distinguished on the core itself by their distinctly lighter color.

Pyrite is a very minor component of this lithofacies and is essentially confined to burrow fillings and to a few synaeresis joints. Organic carbon content of the rock is quite low; the samples studied so far have ranged from 0.0 to 0.9 percent carbon. Two subcategories have been established primarily on the silt content of the mudstone:

(1) Type I-A-under 25 percent silt;

(2) Type I-B-over 25 percent silt (ranging up to argillaceous quartz siltstones).

The silt in all samples was predominantly quartz and feldspar, with carbonate silt being a very minor fraction of the total and largely confined to a few laminae. 
TABLE 10-LITHOFACIES CHARACTERISTICS

\begin{tabular}{|c|c|c|c|c|c|c|c|c|c|c|c|c|c|c|c|c|c|c|c|c|c|c|c|c|c|c|}
\hline & \multicolumn{4}{|c|}{ Color } & \multicolumn{4}{|c|}{ Laminaticns } & \multicolumn{3}{|c|}{ Synaeresis } & \multicolumn{4}{|c|}{ Bioturbation } & \multicolumn{4}{|c|}{ Pyrite } & \multicolumn{4}{|c|}{ Silt } & \multicolumn{3}{|c|}{ Spores } \\
\hline 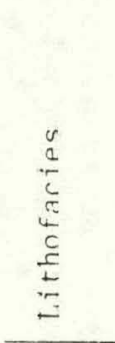 & 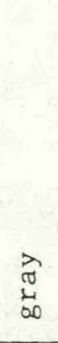 & 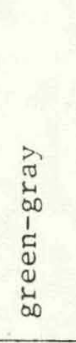 & $\begin{array}{l}\overrightarrow{0} \\
0 \\
0 \\
0 \\
0 \\
0 \\
-1 \\
01\end{array}$ & 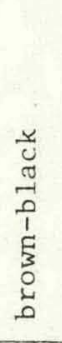 & 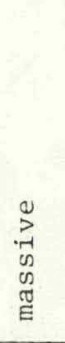 & 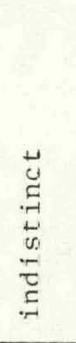 & 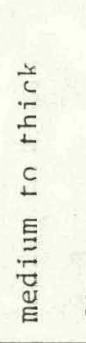 & 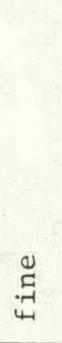 & 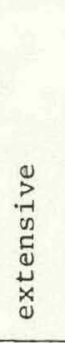 & 峁 & $\begin{array}{l}\overrightarrow{\tilde{N}} \\
0 \\
0 \\
0 \\
0\end{array}$ & 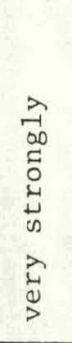 & 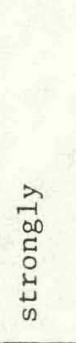 & 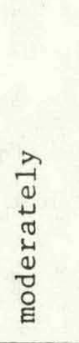 & $\begin{array}{l}0 \\
\text { : }\end{array}$ & 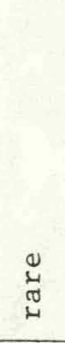 & 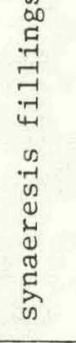 & $\begin{array}{l}0 \\
0 \\
ت \\
ت \\
0 \\
0 \\
0 \\
0 \\
0 \\
0 \\
0 \\
0 \\
د \\
0 \\
0 \\
0\end{array}$ & 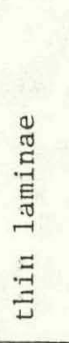 & 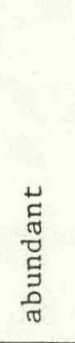 & 苑 & 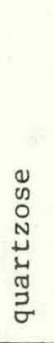 & 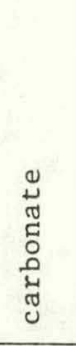 & 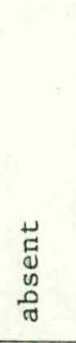 & 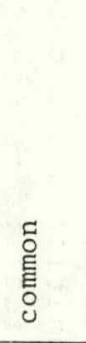 & 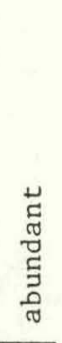 \\
\hline $\mathrm{I}-\mathrm{A}$ & $\mathrm{x}$ & $\mathrm{x}$ & & & $\mathrm{x}$ & & & & & $\mathrm{x}$ & & $\mathrm{x}$ & & & & $\mathrm{x}$ & & & & & $\mathrm{x}$ & $\mathrm{x}$ & & $\mathrm{x}$ & & \\
\hline B & $x$ & $\mathrm{x}$ & & & $\mathrm{x}$ & & & & & $\mathrm{x}$ & & $\mathrm{x}$ & & & & $\mathrm{x}$ & & & & $\mathrm{x}$ & & $\mathrm{x}$ & & $\mathrm{x}$ & & \\
\hline $\begin{array}{r}\text { II }-\mathrm{A} \\
\text { B }\end{array}$ & & & $\begin{array}{l}x \\
x\end{array}$ & & & $\begin{array}{l}x \\
x\end{array}$ & & & $\mathrm{x}$ & $\mathrm{x}$ & & $\mathrm{x}$ & $\mathrm{x}$ & & & & X & $\mathrm{x}$ & & $\mathrm{x}$ & X & $\mathrm{x}$ & $x$ & $\mathrm{x}$ & $\mathrm{x}$ & \\
\hline $\begin{array}{r}\text { III-A } \\
\text { B }\end{array}$ & & & & $\begin{array}{l}x \\
x\end{array}$ & & & $\begin{array}{l}x \\
x\end{array}$ & & $\mathrm{x}$ & $\mathrm{x}$ & $\mathrm{x}$ & & & $\begin{array}{l}x \\
x\end{array}$ & & & x & $\begin{array}{l}x \\
x\end{array}$ & & $\begin{array}{l}x \\
x\end{array}$ & & $\mathrm{x}$ & $\begin{array}{l}x \\
x\end{array}$ & & $\begin{array}{l}x \\
x\end{array}$ & \\
\hline $\begin{array}{r}I V-A \\
B\end{array}$ & & & & $\begin{array}{l}x \\
x\end{array}$ & & & & $\begin{array}{l}x \\
x\end{array}$ & & & $\begin{array}{l}x \\
x\end{array}$ & & & & $\begin{array}{l}x \\
x\end{array}$ & & & $\mathrm{x}$ & $x$ & $\begin{array}{l}x \\
x\end{array}$ & & $\mathrm{x}$ & $\mathrm{x}$ & & & $\begin{array}{l}x \\
x\end{array}$ \\
\hline
\end{tabular}



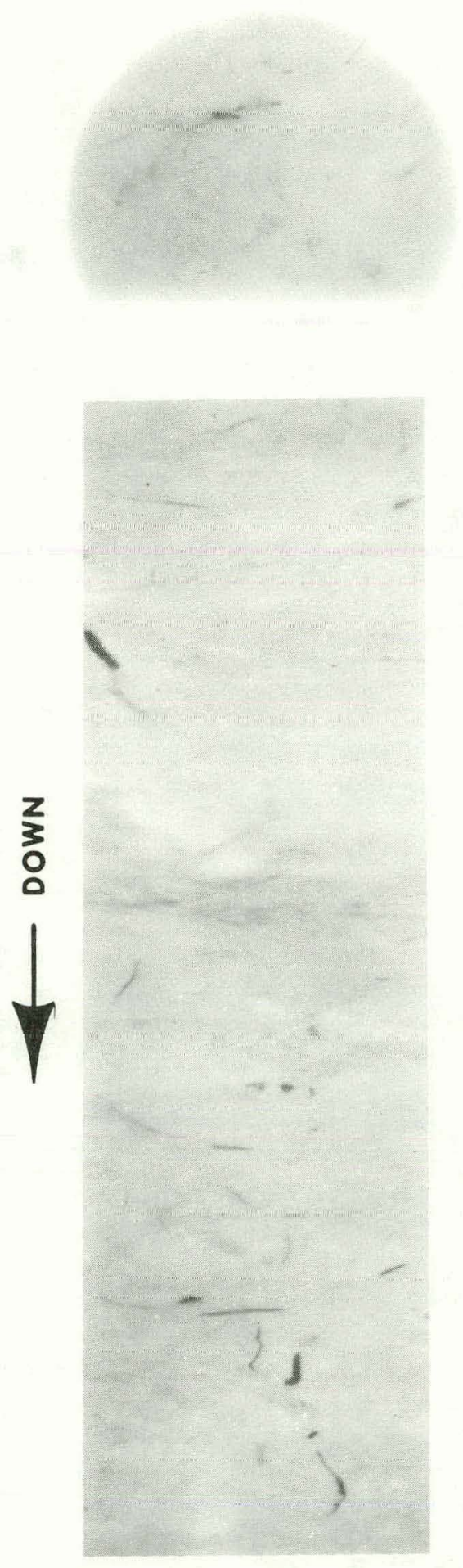

PLATE 2. Bioturbate greenish-gray mudstone. Lithofacies I-B characterized by a swirling texture due to the mixing action of burrowing organisms in the sediment. Short black streaks are pyrite-filled burrows and short synaeresis joints. Lithofacies I-A is similar in megascopic appearance to that shown here of I-B, but is generally finer grained. Sample 01IL04L1. 
Lithofacies I is typical of the Hannibal and Saverton Shales of Illinois, which comprise the upper portion of the New Albany Group. No examples of this lithofacies were present in the 01KY core. We interpret this lithofacies to have been deposited in dysaerobic waters that supported an abundant soft-bodied infauna but did not contain sufficient oxygen to support calcified benthic invertebrates (Rhoads and Morse, 1971). This lithofacies may also represent the shallowest and most highly agitated environment of New Albany deposition, although the absence of depositional sedimentary structures makes this somewhat speculative.

\section{Lithofacies II: Indistinctly bedded olive-gray shales}

Lithofacies II is also characterized by extensive bioturbation, but the sediment was not as completely bioturbated-the general bedding is still discernible. The color of the shale is somewhat darker than that of lithofacics I; it ranges from olive gray to olive black and reflects a higher content of organic matter.

Two subcategories were defined by the abundance of synaeresis and the form and distribution of pyrite:

(1) Type II-A (plate 3A)-very few or no synaeresis joints present, with abundant pyrite nodules along bedding;

(2) Type II-B (plate 3B)-very abundant pyrite-filled synaeresis joints, with few pyrite nodules.

The difference between these lithotypes is interpreted as reflecting different diagenetic environments. Depositional structures and features in the two lithotypes are very similar, except for silt content and mineralogy, with type II-B generally containing less total silt and a greater proportion of carbonate silt. We have found in the samples studied that the early synaeresis joints are filled with pyrite, and they have a very crooked form. We interpret this crookedness to have developed during compaction, but before the formation of late-stage joints. Late-stage synaeresis joints observed in other lithofacies are filled with calcite, and they are much straighter and are nearly vertical. These are interpreted to have formed during a post-compaction stage of diagenesis.

Lithofacies II is typical of portions of the Sweetland Creek Shale. This lithofacies is interpreted as having been deposited in dysaerobic waters similar to litholacies I, except that the activity of burrowers was not as intense. The following are several possible explanations for this:

(1) The uxygen content of the water may have been lower than that of the environment in which lithofacies I was deposited, and thus the population of burrowing organisms was correspondingly smaller. A possible implication is that lithofacies II represents a slightly deeper, less agitated environment.

(2) Some other physical restriction, such as salinity fluctuations, reduced the population of burrowing organisms. Variations in salinity and other chemical characteristics of pore waters in the sediment might also correlate with the diagenetic differences between lithofacies I, II-A, and II-B. 


\section{A}

B
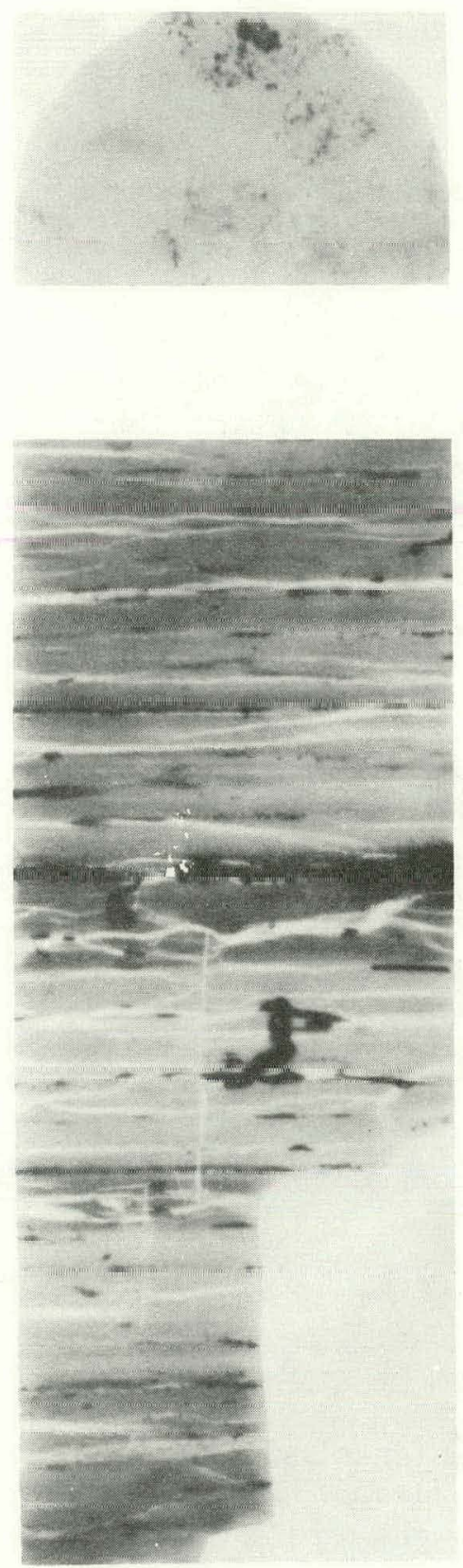
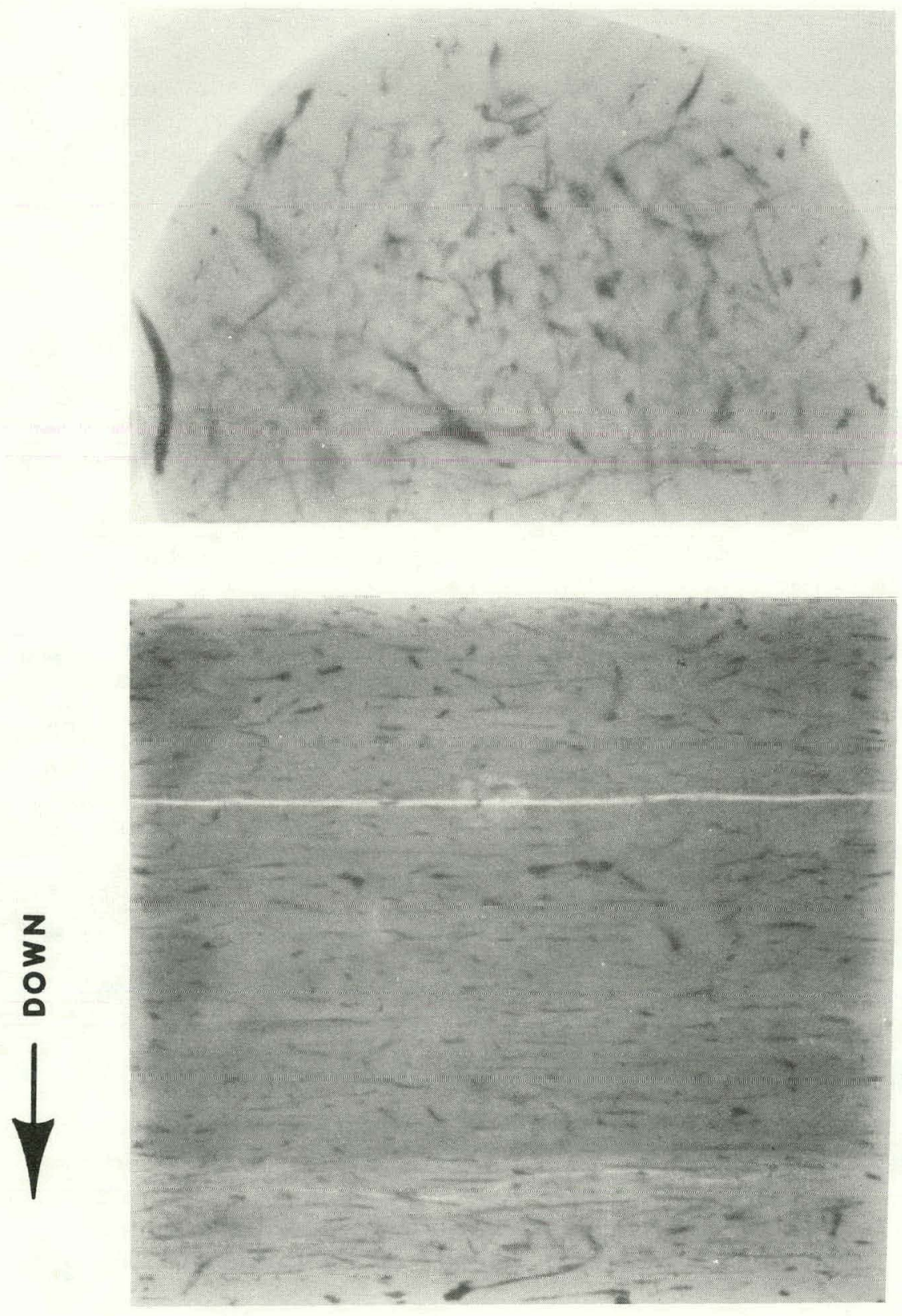

PLATE 3. Indistinctly bedded olive-gray shales. (A) Lithofacies II-A, characterized by indistinct bedding (massive) and abundant pyrite nodules and lenses. Sample 01IL14L1. (B) Lithofacies II-B, characterized by extensive bioturbation and synaeresis joints. The joints are pyrite-filled and were deformed into their crooked form by compaction. Bedding is visible but very indistinct. Sample $01 \mathrm{KY} 06 \mathrm{C} 1$. 
(3) Lithofacies II might reflect a higher rate of deposition. If the burrowing population remained approximately constant, the the intensity of burrowing per volume of sediment might drop.

(4) The faunal composition of the burrowers may have varied geographically and chronologically, with corresponding variations in the size, type, and intensity of burrowing. We do not have sufficient data on trace fossils in the shale to evaluate this possibility.

At this time we do not have sufficient data to speculate on the controls of synaeresis development and of pyrite distribution.

\section{Lithofacies III: Poorly laminated brownish-black shales}

Lithofacies III is characterized by distinct but variable lamina-

tions. Finely laminated shales are interbedded with massive or very thickly laminated shales (plate 4B). Sporadic burrows are visible, but sediment mixing is minimal ( $\mathrm{p}$ late $4 \mathrm{~A}$ ). The organic content of the shales is generally high ( 3 to 9 percent), and they are predominantly brownish black. synaeresis:

Two subcategories were established principally on the basis of

(1) Type III-A (plate 4A)-very few synaeresis joints;

(2) Type III-B (plate 4B)-abundant synaeresis joints.

In addition, all of the samples of lithofacies III-A contain sedimentary structures such as cuts and fills, ripples, cross-bedding, and small loads. Although it is tempting to interpret this lithofacies as a high-current velocity facies of the New Albany, it seems likely that similar sedimentary structures were originally present in the sediments of lithofacies I and II, but were subsequently destroyed by extensive burrowing. (These structures do indicate greater current activity than the finely laminated brownishblack shales of lithofacies IV.)

Lithofacies III is typical of portions of the Sweetland Creek Shale and some areas of the Grassy Creek Shale. The lithofacies is interpreted as haviuy been deposited in marginal anaerobic/dysaerobic waters, in which only a very few burrowing organisms could survive; oxidation of organic matter in the sediment was negligible. This lithofacies was presumably deposited in deeper waters than was either lithofacies I or II. In modern euxinic basins, such as the Black Sea, the mixing of surficial waters can transfer oxygen to depths of approximately 150 meters, below which anaerobic conditions prevail (Caspers, 1957). Byers (personal communication, 1977) has suggested that 150 meters is a reasonable minimum depth for the anaerobic/dysaerobic boundary in certain ancient settings.

\section{Lithofacies IV: Finely laminated brownish-black shales}

Lithofacies IV is characterized by fine, evenly spaced, parallel laminations of pyrite and silt. There is no indication of disturbance by burrowing. The uniformity of the laminations indicates that they are pelagic 


\section{A}
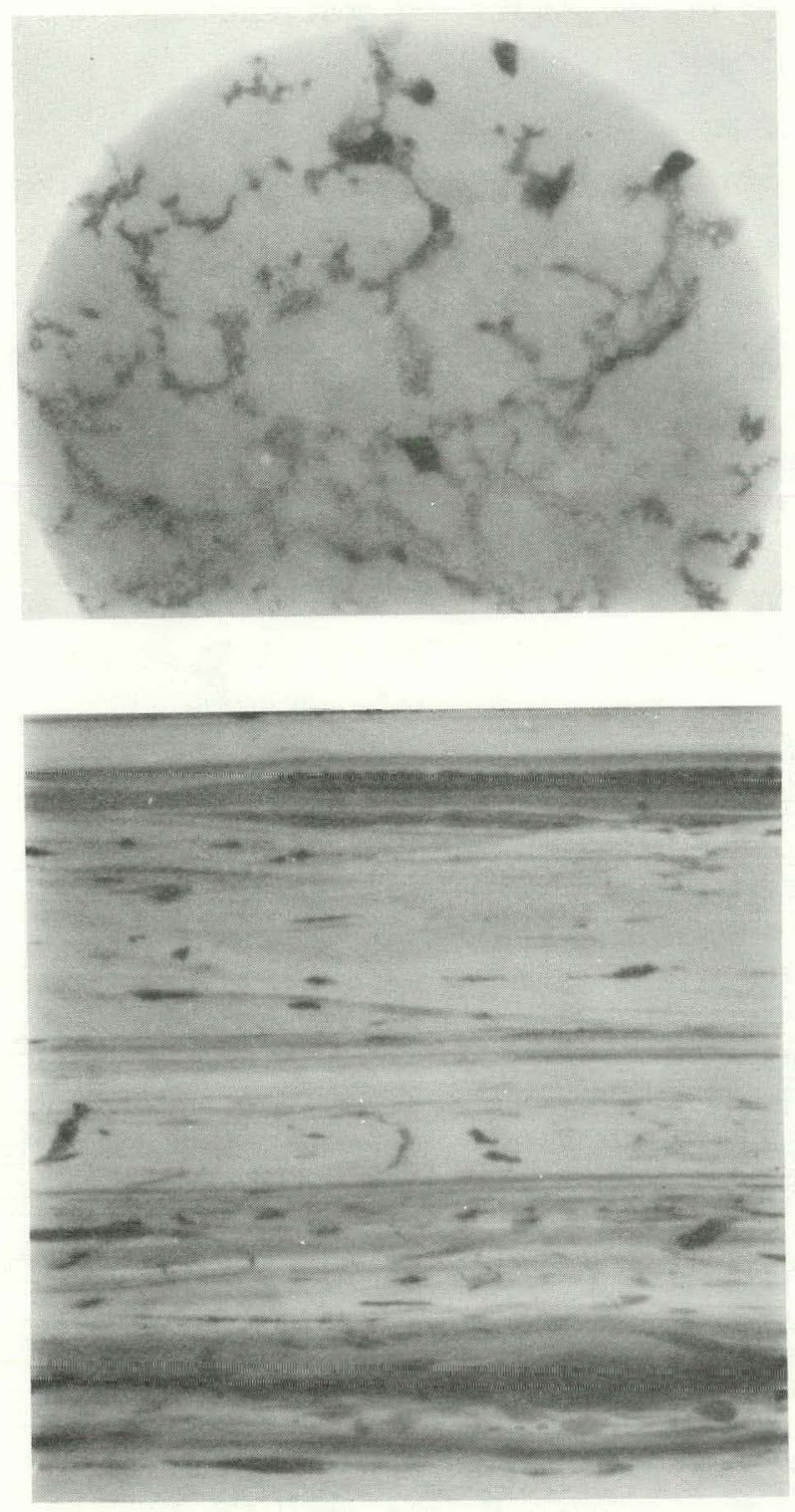
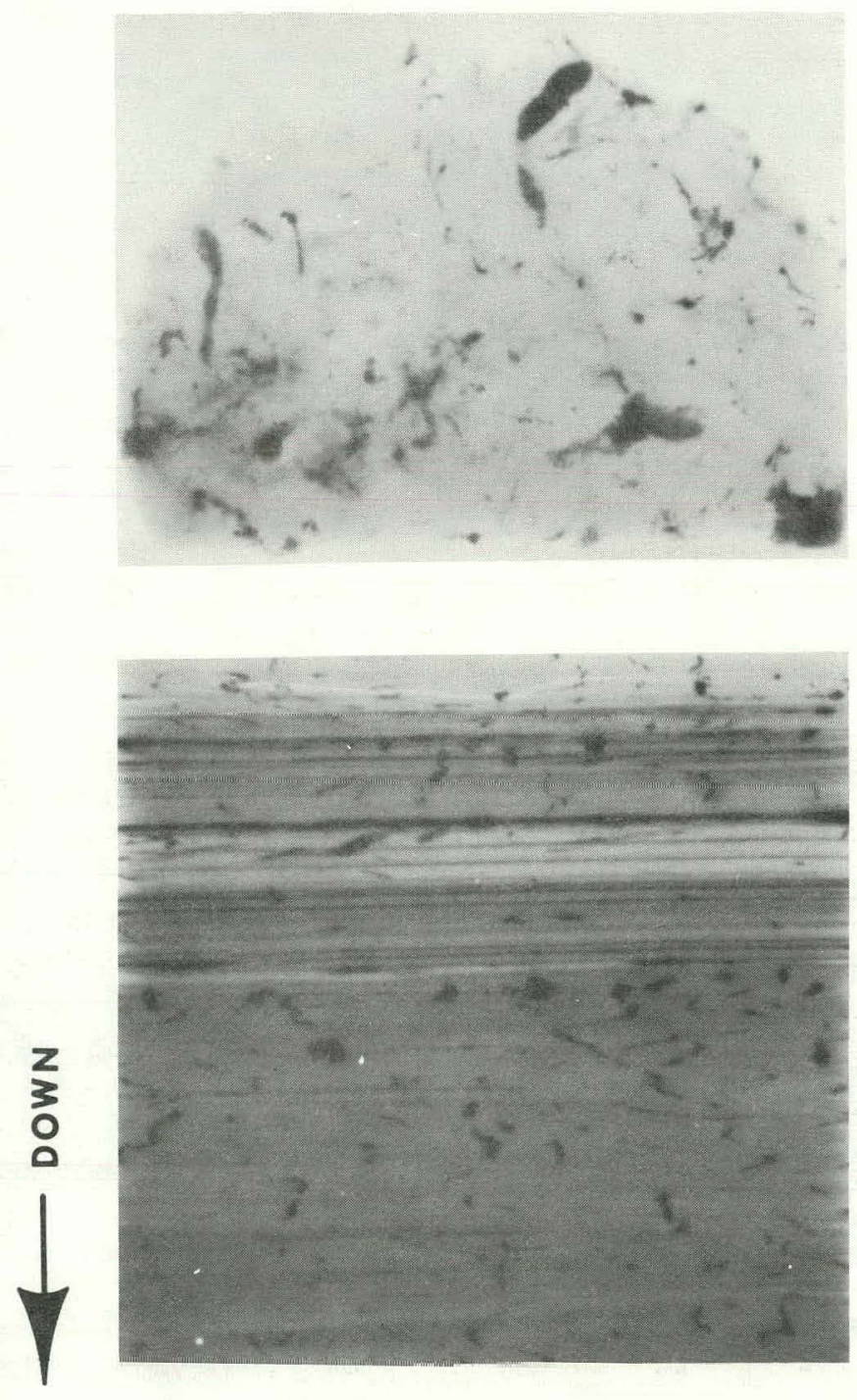

PLATE 4. Poorly laminated brownish-black shales. (A) Lithofacies III-A, characterized by medium to coarse laminations. Few synaeresis joints, sporadic burrowing, and few primary sedimentary structures such as ripples and cross-bedding are present. Sample 01KY08C1. (B) Lithofacies III-B, a1so characterized by medium to coarse laminations and weak bioturbation, but with much more extensive synaeresis development. Primary sedimentary structures, other than laminations, are absent. Sample 01KY11L1. 
sediments and were not deposited by traction or density currents. Spores are abundant in most samples, and organic content is high (generally 5 to 14 percent). Color ranges from brownish-black to gray-black to black.

Two subcategories, defined by a very striking difference in the form of pyrite in the shale, probably reflect differences in the diagenetic environment :
(1) Type IV-A (plate 5A)-pyrite is evenly dispersed through the shale as minute grains and as fine lami- nae;
(2) Type IV-B (plate 5B)-pyrite is principally clumped into small scattered nodules, although scattered grains and pyritic laminae are also present as in Type IV-A.

Lithofacies IV is typical of the Grassy Creek and Blocher Shales. This lithofacies is interpreted as having been deposited in anaerobic waters devoid of benthic organisms. It probably represents the deepest, quietest conditions of New Albany deposition. Little evidence of currents in this lithofacies environment was found, and pelagic sedimentation was probably dominant.

The occurrence of straight, near vertical, calcite-filled synaeresis joints (feature near center of plate 5B) in this 1ithofacies suggests that acid treatment of wells drilled in the New Albany to dissolve the calcite might prove to be effective in creating fractures cross-cutting shale and siltstone strata, and thereby might increase the rate of flow of hydrocarbons into the we11. Because these synaeresis joints are straight and uncompressed, they are interpreted to have formed during a post-compaction stage of diagenesis.

\section{Relation of lithofacies to physical properties}

The lithofacies classification is not a quantitative parameter, but several of the criteria used to distinguish the classes are based on qualitative descriptive properties. The classes are thought to be, most significantly, a relative measure of the oxygen content of the depositional environment, with decreasing oxygen corresponding to increasing lithofacies class number. It is therefore useful to consider the relations between the lithofacies and the results of certain physical property tests. Some result. of physical property tests, reported later (fig. 27 and tables 39 and 40) are correlated with the lithofacies in figure 24. Comparison of the data shuw lithofacies class increases with increasing internal surface area ratio (fig. $24 \mathrm{~A})$. Because this ratio is a relative measure of the abundance of pores in the sample whose diameters are about 4 to $5 \AA$, the graph is interpreted to indicate that the more anaerobic the site of deposition, the more abundant the ultrafine pores in the final lithified shale. The relation of lithofacies with hardness is shown in figure 24. It is apparent from this graph that the lower the lithofacies class, the softer the shale is likely to be. Although many samples of lithofacies IV tested as soft as those of I through III, several samples of each are proportionately harder with increasing class number. There is little or no relation of significance between lithofacies and clay orientation index (fig. 24C). 


\section{A}
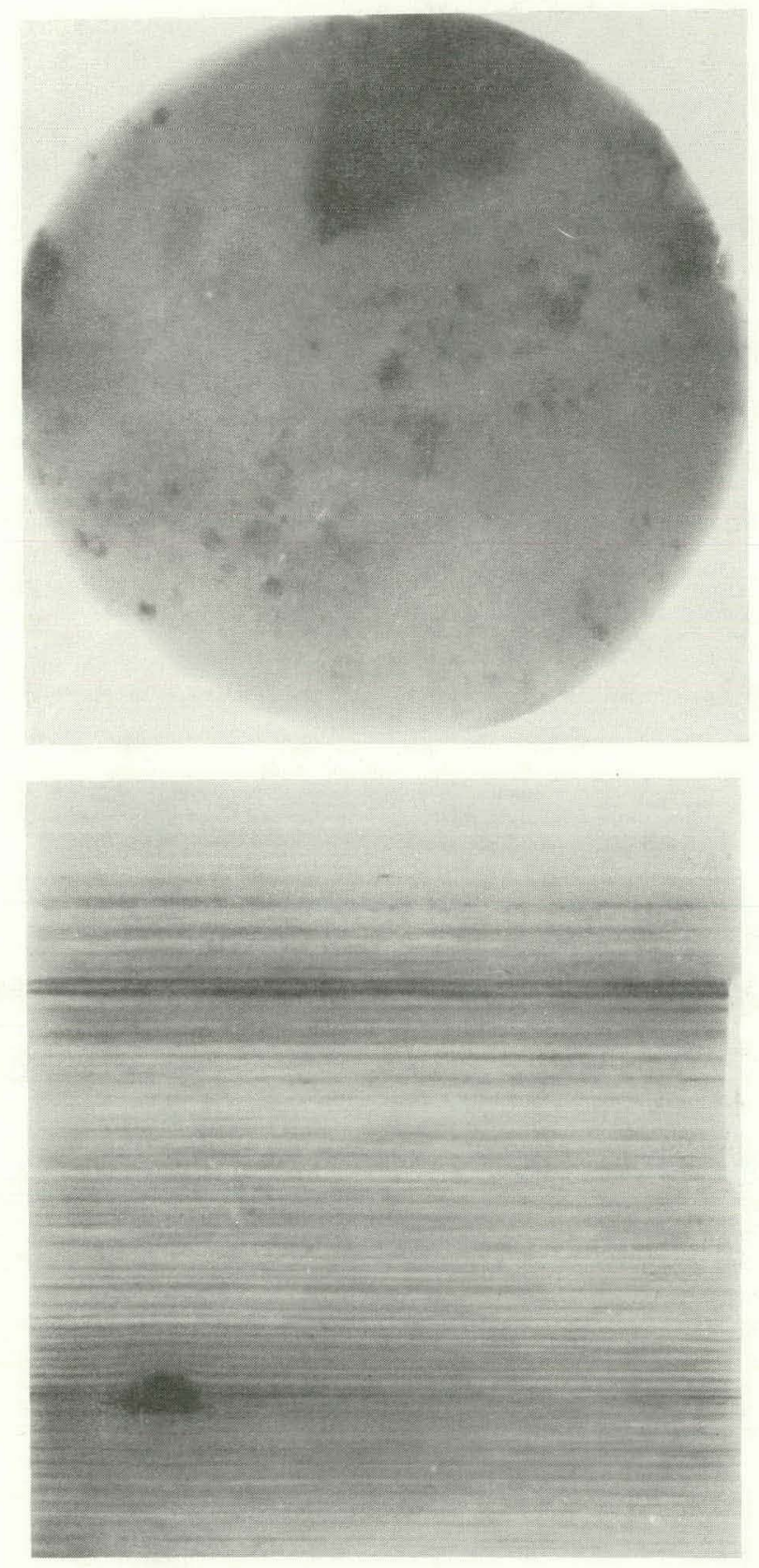

B
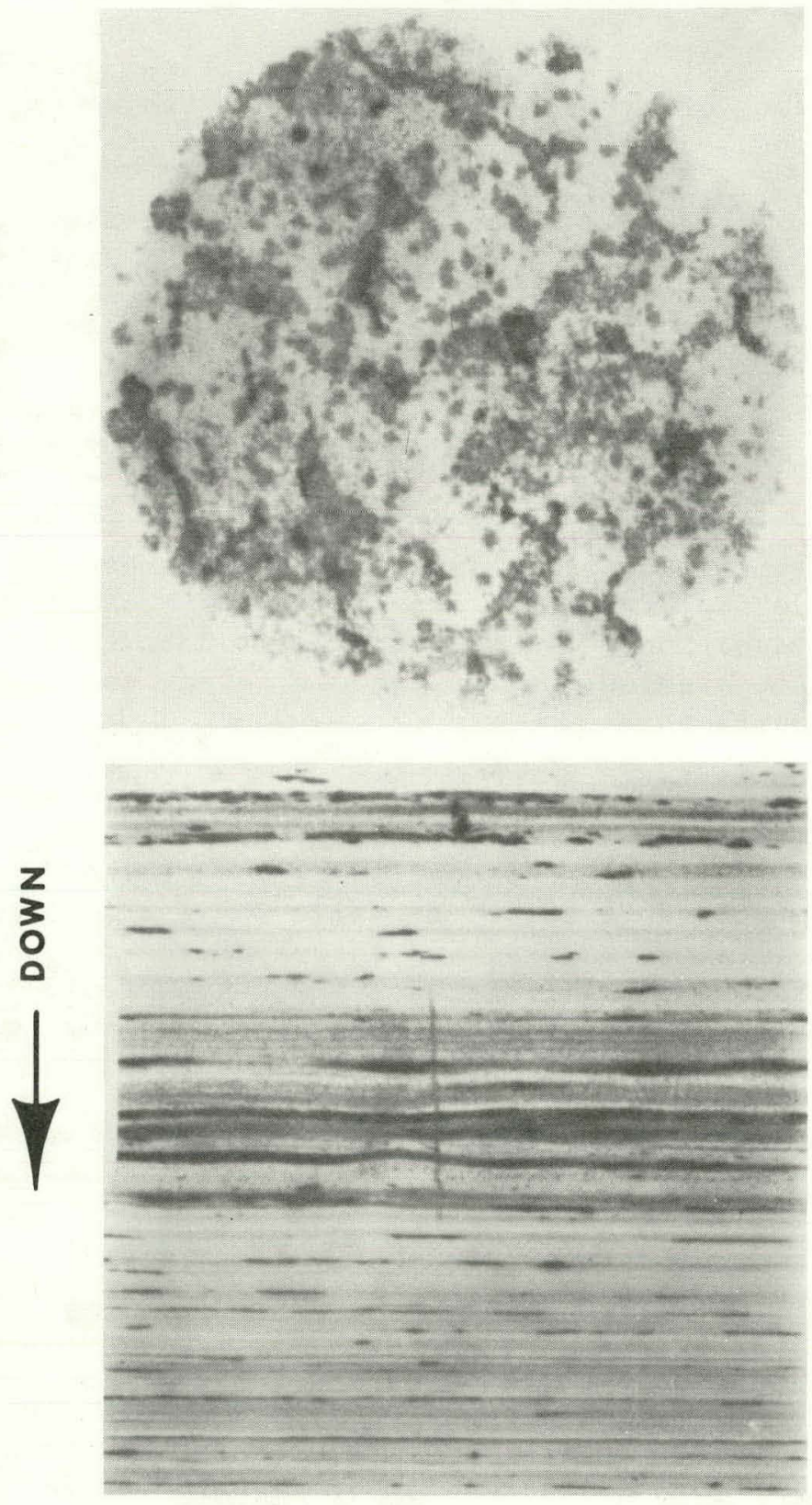

PLATE 5. Finely laminated, brownish-uıack shales. (A) Lithofacies IV-A, characterized by very fine and closely spaced pyritic laminae and an occasional large pyrite nodule (as at lower left). Sample 01KY01L1. (B) Lithofacies IV-B, characterized by slightly thicker and more irregular laminae and by numerous small pyrite nodules. Short vertical lineation at the center of the radiograph is a late stage (post-compaction) synaeresis joint filled with calcite. Sample 01KY03L1. 

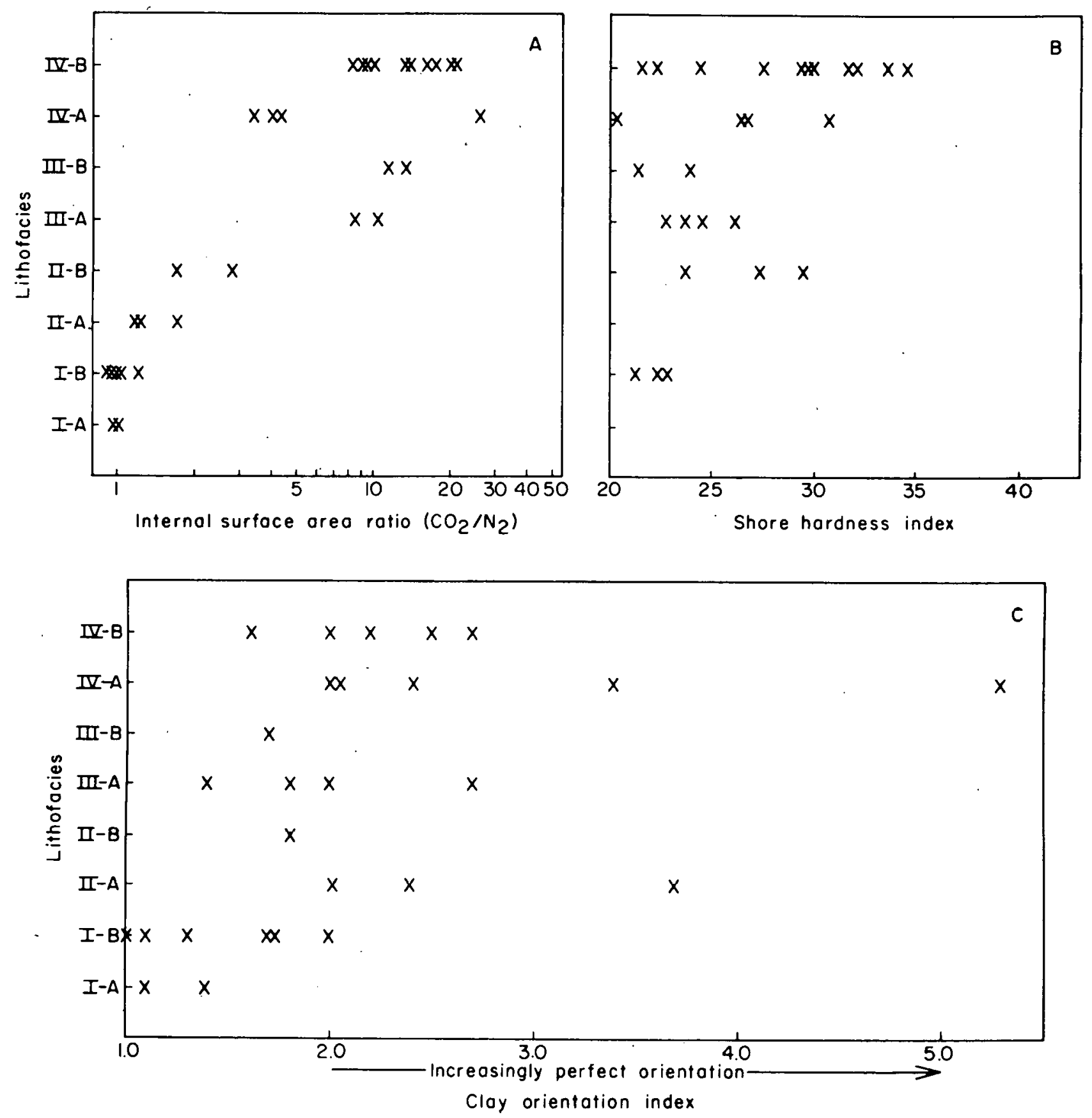

Fig. 24. Relation of lithofacies classification to (A) internal surface area ratio, (B) shore hardness index, and (C) clay orientation index. 
(1) Effingham County, Illinois, (02IL) core-Slabs have been cut and radiographs taken for 13 samples from this core. Clay mineralogy and clay orientation analysis has been completed for the 11 shale samples in this sample set. Maceration for vitrinite refletance analysis and thin section preparation are in progress.

(2) White County, Illinois, (03IL) core-Clay mineralogy, x-ray diffraction analysis of whole powders, and maceration of crushed samples for vitrinite reflectance analysis are in progress. Thin sections and clay orientation slabs will also be prepared. Because the original core was destroyed, radiography of core slabs is not possible.

(3) Henderson County, Illinois, (04IL) core-Detailed logging of the core has been completed and lithologic samples have been selected.

\section{REFERENCES}

Caspers, H., 1957, Black Sea and Sea of Azov: Ireatise on Marine Ecology and Paleoecology, Geological Society of America Memoir 67, v. 1, p. 801-890.

Hollingworth, S. E., and F: A. Bannister, 1950, Basaluminite and hydrobasaluminite, two new minerals from North Hamptonshire: Mineralogical Magazine, v. 29, no. 208, p. 1-17.

Hood, A., C. C. M. Gutjahr, and R. L. Heacock, 1975, Organic metamorphism and the generation of petroleum: American Association of Petroleum Geologists Bulletin, v. 59, no. 6, p. 986-996.

Milton, Charles, L. C. Connane, and V. E. Swanson, 1955, Sub=Chatlanuoga residuum in Tennessee and Kentucky: Geological Society of America Bulletin, v. 60 , p. $805 \cdots 810$.

Moore, D. G., and P. C. Scruton, 1957, Minor internal structures of some recent unconsolidated sedimento: American Aosociatione of Petrom leum Geologists Bulletin, v. 41, p. 2723-2751.

Odom, I. E., and W. E. Parham, 1968, Petrology of Pennsylvanian underclays in Illinois and their application to some mineral industries: Illinois Geological Survey Circular 429, $36 \mathrm{p}$.

Parham, W. E., 1962, Clay mineral facies of certain Pennsylvanian underclays: $\mathrm{Ph}$. D. thesis, University of Illinois, Urbana, $122 \mathrm{p}$.

Parham, W. E., 1966, Lateral variations of clay mineral assemblages in modern and ancient sediments: in Proceedings, International Clay Conferences, Jerusalem, Israe1, v. 1, p. 135-145.

Reitlinger, E. A., 1957, Spheres in the Devoniàn deposits of the Russian Platform: Proceedings, Academy of Sciences USSR, Geological Sciences, Sec. 1, v. 115, p. 625-628.

Rhoads, D. C., and J. W. Morse, 1971, Evolutionary and ecologic significance of oxygen-deficient marine basins: Lethaia, v. 4, p. 413-428. 
Rhoads, D. C., 1974, Organism-sediment relations on the muddy sea floor: Oceanogr. Marine Biology Annual Review, v. 12, p. 263-300.

Staplin, F. L., 1977, Interpretation of thermal history from color of particulate organic matter-A review: in Palynology, v. 1, Proceedings of the 8th Annual Meeting of the American Association of Stratigraphic Palynologists, Houston, TX, October 1975, p. 9-18.

Textoris, D. A., and A. V. Carozzi, 1964, Petrography and evolution of Niagaran (Silurian) reefs, Indiana: American Association of Petroleum Geologists Bulletin, v. 48, no. 4, p. 397-426. 


\title{
IIIG. Analysis of physical properties of the Devonian Black Shale
}

\author{
P. B. DuMontelle and S. R. Hunt
}

SCUYE AND PURPUSE

This project is a study of the index properties, directional properties, and strength of oriented core of Devonian black shale from the Illinois Basin. Index properties include moisture content, specific gravity, bulk density, and Shore-hardness. Directional seismic velocities will be determined with an acoustical bench. Strength tests include point load fracture strength, and indirect tensile strength (Brazilian split). Fracture frequency, drilling rate, and core recovery are also compiled as an additional mechanical index.

\section{ACCOMPLISHMENTS}

(1) A portion of the Illinois State Geological Survey Annex Building was established for temporary core storage, orientation of core, logging, marking, Shore-hardness testing, sampling, and cutting. A laboratory measuring $43 \times 16 \mathrm{ft}$ has been prepared in the Natural Resources Building for the compressive and tensile-strength testing equipment and for the acoustical bench for measuring directional seismic velocity.

(2) The laboratory facilities for acoustical and strength testing procedures have nearly been completed (Milestones 25-28). Routine testing will begin as soon as the shale samples have been properly prepared.

(3) The determination of index properties has been completed on three of the cores received (Christian County, KY; Effingham County, Henderson County, IL). The logging and processing of the most recent core (Tazewell County) is still in progress. In addition, the same index properties, where applicable, are being determined for three additional unoriented cores from Survey files.

(4) Analysis of physical properties of the Devonian black shale has produced abundant information. To handle the data more effectively, an interactive retrieval system is being developed, in conjunction with the Illinois State Geological Survey MINERS computer system utilizing an ALTAIR minicomputer and the University of Illinois CYBER computer.

The purposes of the computer facilities set up in Group IIIG are twofold: first, to provide a system and a dedicated terminal to encode borings and samples studied by the Survey, retaining a master file of location, depth, and other well information as well as distribution of each sample studied; and, second, to file and manipulate secondary information generated by Group IIIG. 


\section{METHODS}

Group IIIG is handling orientation, sampling, and distribution of samples to other study groups (see fig. 25). A standardized system to handle core and to identify samples was developed to interface laboratory data with our computer system. The acquisition of data is organized as follows:

(1) Core received by the Illinois State Geological Survey is initially logged by the Stratigraphy and Structure Group (IG).

(2) Mineralogic and Petrographic Group (IIG) reviews logs of Group IG and selects and marks the core where samples are to be cut for lithologic studies (L samples).

(3) Group IIIG then proceeds as follows:

(a) Orients and marks the core with north line (red.)

(b) Determines data-set size and marks core and boxes.

(c) Each data set is logged for fractures and tested for hardness (Shore), and selected core is marked for sampling for sonic testing ( $S$ ), indirect tensile strength tests ( $T$ ), and point load tests $(P)$. The information is recorded on printed data sheets (fig. 26) along with all other sampling data.

(d) Samples are then distributed to laboratories using letter and color code identification.

(e) After degassing, samples from Chemical Group (canned) are returned to the Annex Laboratory, oriented, marked with north line, and then sent to Group IIG for lithologic studies.

(4) On June 28 and 29, 1977, Pau1 B. DuMontelle attended the Eastern Gas Shales Fractography Workshop, under the direction of Dr. Byron R. Kulander of Alfred University. In light of knowledge gained from this meeting, cores were re-examined by DuMontelle, Bonnie Witek, Richard Harvey, and Robert Cluff to attempt to classify the genesis of the propagation of observed fractures.

Fractures logged were noted as being natural (N) or induced by coring or handling (C). Factors suggesting natural fracture included the following: (a) high angle (usually near vertical), (b) smooth surface, (c) mineralization, (d) slickensides.

Coring induced (Cs), disc-1ithology (Cd), and handling fractures (Ch) were identified by typical features as follows: (a) rough surface, (b) curve to free face (petal or hook), (c) characteristic propagation flaw features, (d) fresh surfacc.

(5) Information from data sheets (fig. 26) will serve as inpuit to the Illinois State Geological Survey computer memory storage through terminal facilities to be set up in Room 32 of the Natural Resources Building. A cathode ray tube (CKT) with keyboard and a computerized typewriter will be used to file and edit the data. No keypunching will be required. Data input and editing will be done through a direct communications link with the computer.

Equipment has been ordered to connect the laboratory instruments to the computer terminal. 


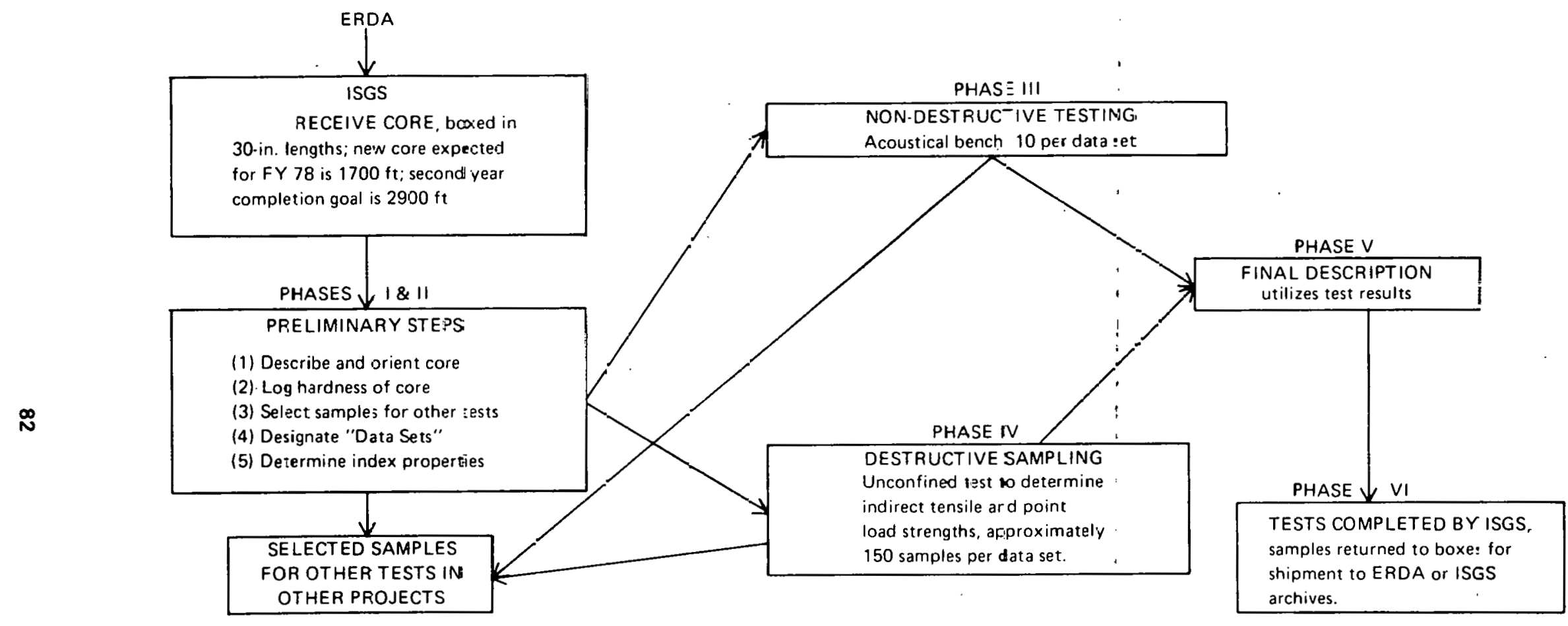

Fig. 25. Work plan for core routing and anzlysis o Jirectional properties. 
API Code Number

Illinois Code Number

Well Information

Company:

Contractor:

Well Name:

County:

State:

Hole Size:

Core Barrel:

Formation Name:

Formation Descriptióri:

\begin{tabular}{c}
$\frac{\text { Legend }}{\text { Code }}$ \\
\hline $\mathrm{L}$ \\
$\mathrm{C}$ \\
$\mathrm{S}$ \\
$\mathrm{P}$ \\
$\mathrm{T}$ \\
$\mathrm{M}$ \\
$\mathrm{O}$
\end{tabular}

\begin{tabular}{|c|c|c|}
\hline Sample & Size & $x / 10^{\prime}$ \\
\hline lithologic(green) & $\overline{.4 \mathrm{ft}}$ & $\overline{1 / 10^{\prime}}$ \\
\hline chemical(canned)(blue) & $.2 \mathrm{ft}$. & $1 / 10^{\circ}$ \\
\hline sonic(yellow) & $.5 \mathrm{ft}$. & $2 / 10^{\prime}$ \\
\hline point load(red) & $.2 \mathrm{ft}$. & $10 / 10$ \\
\hline tensile(brown) & $.2 \mathrm{ft}$ & $6 / 10^{\circ}$ \\
\hline moisture(purple) & & $1 / 10^{\circ}$ \\
\hline
\end{tabular}

Data Set -

Interval.

Date:

graphic log elevation remarks

graphic log elevation remarks

of fractures

of fractures
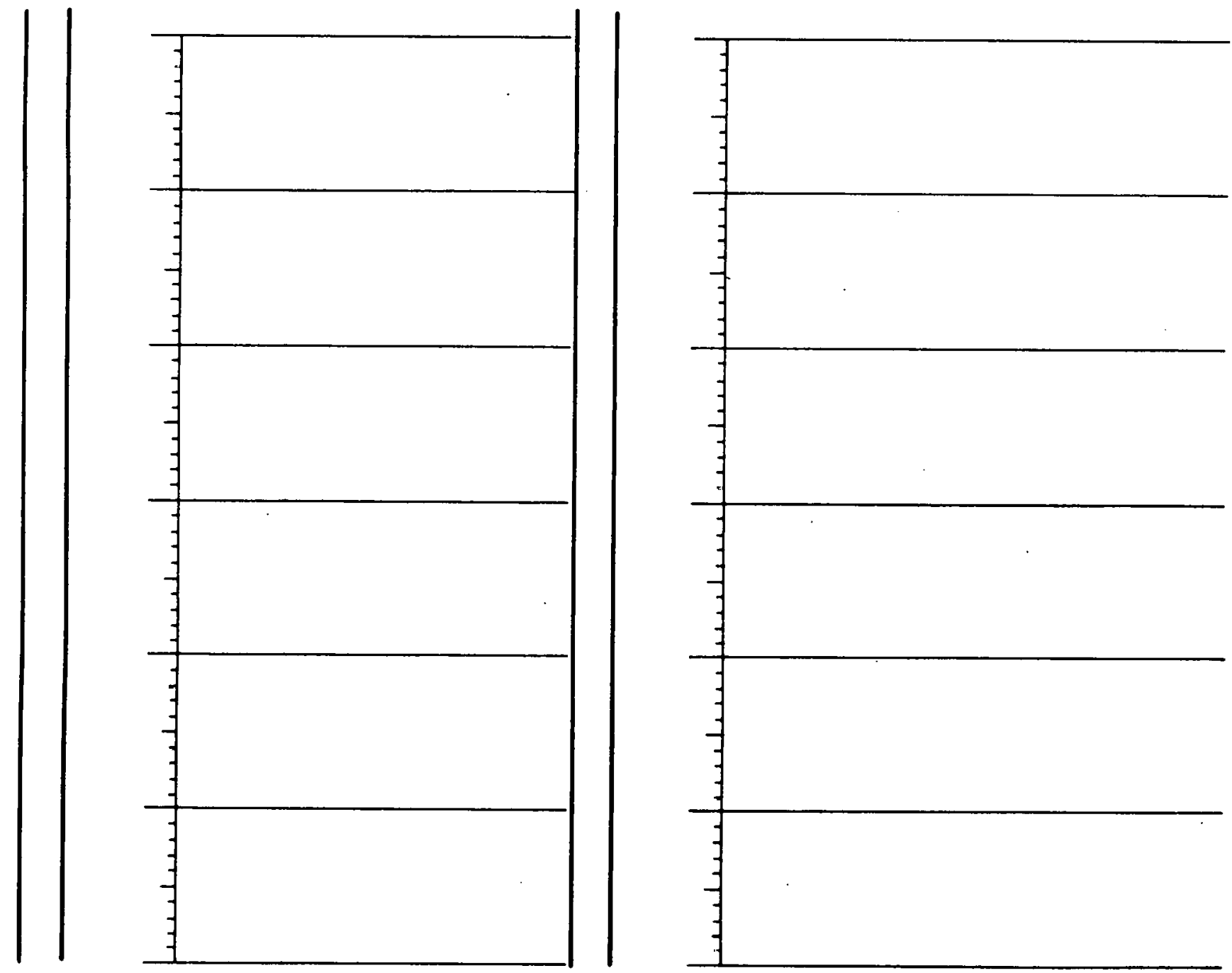

Fig. 26. Data sheet used to record information about physical properties and distribution of samples to Illinois State Geological Survey and other laboratories. 


\section{RESULTS}

To date, seven cores containing the New Albany Shale-six from Illinois and one from Kentucky-have been or are being processed. Four of the cores totalling approximately $770 \mathrm{ft}$ in length are oriented. Three additional cores totalling over $200 \mathrm{ft}$ in length have been selected from Survey files. Table 11 summarizes this information as well as the distribution of samples within the Survey and outside labs.

The inder proportios for all cores received have been determined or are in progress. This information is summarized in table 12 . The results of index property determinations for the oriented core are tabulated in figures 27 to 30 . This material has been summarized and averaged on the basis of data sets or approximately $10 \mathrm{ft}$ intervals. A statistical analysis of these data will be made when the results of the destructive and acoustical testing are completed.

\section{DISCUSSION OF RESULTS}

$\Lambda t$ this point in the study, a discussion of the index properties is not warranted other than to say that cercalu 1llhulugll unils do show roughly predictable results. As an example, the gray shales appear to have many more fractures than the black or darker gray shales. However, this probably only reflects the fragile nature of the core, since the vast majority of fractures were determined to be induced by coring or handling rather than to be natural fractures.

The bulk of the core received has been subject to severe slaking and is very reactive to moisture. Because this has proven to be a major problem in subsampling for other tests, the results of the mechanical testing will probably not be representative of the rock mass, since only a very few strong samples have been obtainable from certain zones. In core 04IL, for example, only 28 of required 60 acoustical samples, 137 of 300 point load samples, ynd 80 of 180 tensile samples could be obtained. Several sections 20-30 fe long yiclded no camploe at 211.

The availability of sound core for physical tests is also hampered by the fact that much of the "good" core has been selecied alld lemuvel in advance by other contractors (see table 25). In core 04Ii, for example, the following samples were removed: Battelle, 31 samples; Mound, 10 samples; Northern I1. Gas, 3 samplcs; Stanford Res. Inst., 6 samples; Institute for Gas Technology; 8 samples; and Juniata Junior College, 6 samples.

The poor quality of the rock obtained is probably relaled to the shallow depth of occurrence. If new core sites are for shallow core, then the number of physical property samples obtainable will probably be restricted to one-third to one-half of the number required. 
TABLE 11-STATUS OF CORE DISTRIBUTION AND SAMPLING (SEPT. 1977)

\begin{tabular}{|c|c|c|c|c|c|c|c|c|c|c|}
\hline \multirow{3}{*}{$\begin{array}{c}\begin{array}{c}\text { Core } \\
\text { number }\end{array} \\
01 \mathrm{KY}\end{array}$} & \multirow{2}{*}{\multicolumn{2}{|c|}{$\begin{array}{c}\text { Core } \\
\text { length ( } f t .)\end{array}$}} & \multirow{2}{*}{\multicolumn{3}{|c|}{$\begin{array}{l}\text { No. of samples to } \\
\text { contract laboratories }\end{array}$}} & \multicolumn{5}{|c|}{$\begin{array}{c}\text { Illinois State Geologic Survey } \\
\text { Samples (非) }\end{array}$} \\
\hline & & & & & & Lithologic & Chemical & Sonic & Point Load & Tensile \\
\hline & 152 & & $\begin{array}{l}\text { Battelle } \\
\quad 14\end{array}$ & $\begin{array}{l}\text { Mound } \\
4\end{array}$ & $\begin{array}{c}\text { Indiana Geol. } \\
\text { Soc. } \\
1\end{array}$ & 12 & 13 & 22 & 110 & 66 \\
\hline CIIL & 208 & $\begin{array}{l}\text { Not } \\
\text { Oriented }\end{array}$ & & & $\underset{I}{I . E . Q \cdot}$ & 18 & 0 & 3 & 22 & 12 \\
\hline $02 \mathrm{IL}$ & 101 & & $\begin{array}{l}\text { Battelie } \\
\quad 14\end{array}$ & $\begin{array}{l}\text { Mound } \\
7\end{array}$ & $\begin{array}{c}\text { Juniata } \mathrm{Jr} \text {. } \\
\text { Coll } \\
6\end{array}$ & 5 & 9 & 11 & 59 & 37 \\
\hline $03 I L *$ & $\begin{array}{l}\text { Reduced } \\
\text { core }\end{array}$ & $\begin{array}{l}\text { Not } \\
\text { Oriented }\end{array}$ & & & & & & & & \\
\hline $04 \mathrm{IL}$ & 300 & & $\begin{array}{l}31 \text { Battelle } \\
6 \text { S.R.I. }\end{array}$ & $\begin{array}{l}10 \text { Mound } \\
8 \text { I.G.T. }\end{array}$ & $\begin{array}{l}3 \text { N.I.G. } \\
6 \text { Juniata }\end{array}$ & 4 & 31 & 28 & $1 \%$ & 80 \\
\hline $05=L$ & 9 & $\begin{array}{l}\text { Not } \\
\text { Oriented }\end{array}$ & & & & & & & . & \\
\hline $06 I L$ & 260 & & . & in $p r o g r$ & ess & & & & & \\
\hline
\end{tabular}

* Not suitable for indexing or physical testing. 
TABLE 12-STATUS OF INDEX PROPERTY TESTING (SEPT. 1977)

\begin{tabular}{|c|c|c|c|c|c|c|c|c|}
\hline Core & $\begin{array}{c}\text { Core } \\
\text { number }\end{array}$ & $\begin{array}{l}\text { Orientation } \\
\dot{\alpha} \text { logging }\end{array}$ & $\begin{array}{l}\text { Fracture } \\
\text { sequence }\end{array}$ & $\begin{array}{c}\text { Shore } \\
\text { hardness }\end{array}$ & $\begin{array}{l}\text { Specific } \\
\text { gravity }\end{array}$ & $\begin{array}{l}\text { Moisture } \\
\text { cortent }\end{array}$ & $\begin{array}{l}\text { Drilling } \\
\text { rate }\end{array}$ & $\begin{array}{l}\text { Core } \\
\text { recovery }\end{array}$ \\
\hline $01 \mathrm{KY}$ & . & Nov. 1976 & $\mathrm{X}^{*}$ & $\mathrm{X}$ & $\mathrm{x}$ & $\mathrm{x}$ & & \\
\hline 01IL & not oriented & Nov. 1976 & $\mathrm{NA}^{+}$ & $\mathrm{x}$ & $\mathrm{x}$ & INA & $N A$ & NA \\
\hline 02 IL & & March 1977 & $\mathrm{x}$ & $\mathrm{x}$ & $\mathrm{x}$ & $\mathrm{x}$ & & \\
\hline 03IL & $\begin{array}{l}\text { not oriented } \\
\text { reduced core }\end{array}$ & June 1977 & NA & NA & $\mathrm{NA}$ & $\mathrm{NA}$ & $\mathrm{NA}$ & $\mathrm{NA}$ \\
\hline $04 \mathrm{IL}$ & $\begin{array}{l}\text { poor quality rack } \\
\text { (slacks upon sawing) }\end{array}$ & Sept. 1977 & & $\mathrm{x}$ & $\mathrm{x}$ & $\mathrm{x}$ & $\mathrm{X}$ & $\mathrm{x}$ \\
\hline 05IL & not oriented & Nov. 1977 & & & $\mathrm{X}$ & & & \\
\hline $06 \mathrm{IL}$ & & Oct. $197 \bar{T}$ & & & $\mathrm{X}$ & $\mathrm{x}$ & $\mathrm{X}$ & $\mathrm{x}$ \\
\hline
\end{tabular}

$* \mathrm{X}=$ completed

${ }_{\mathrm{NA}}=$ not available 


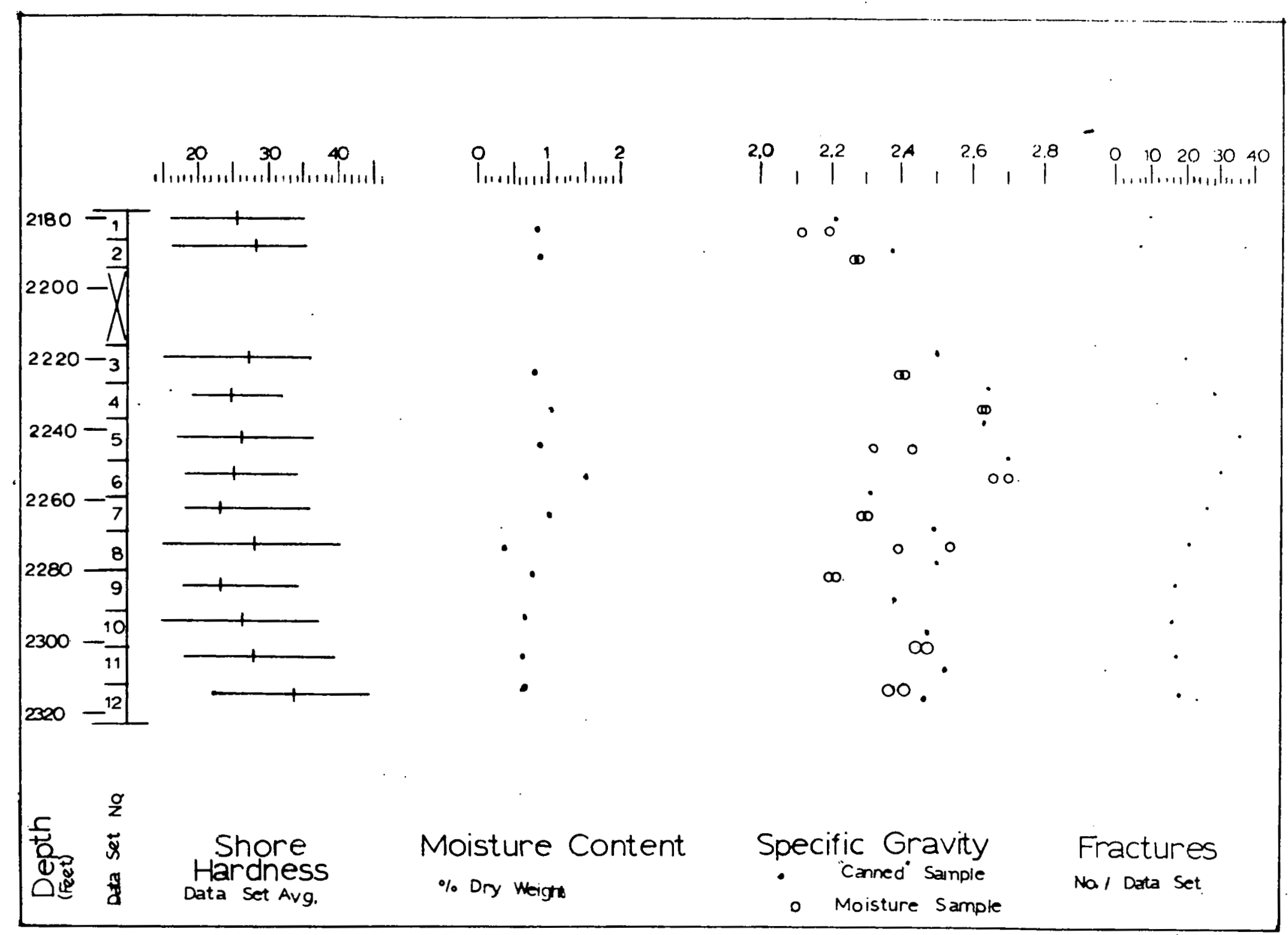

Fig. 27. Index properties, 01KY core. 


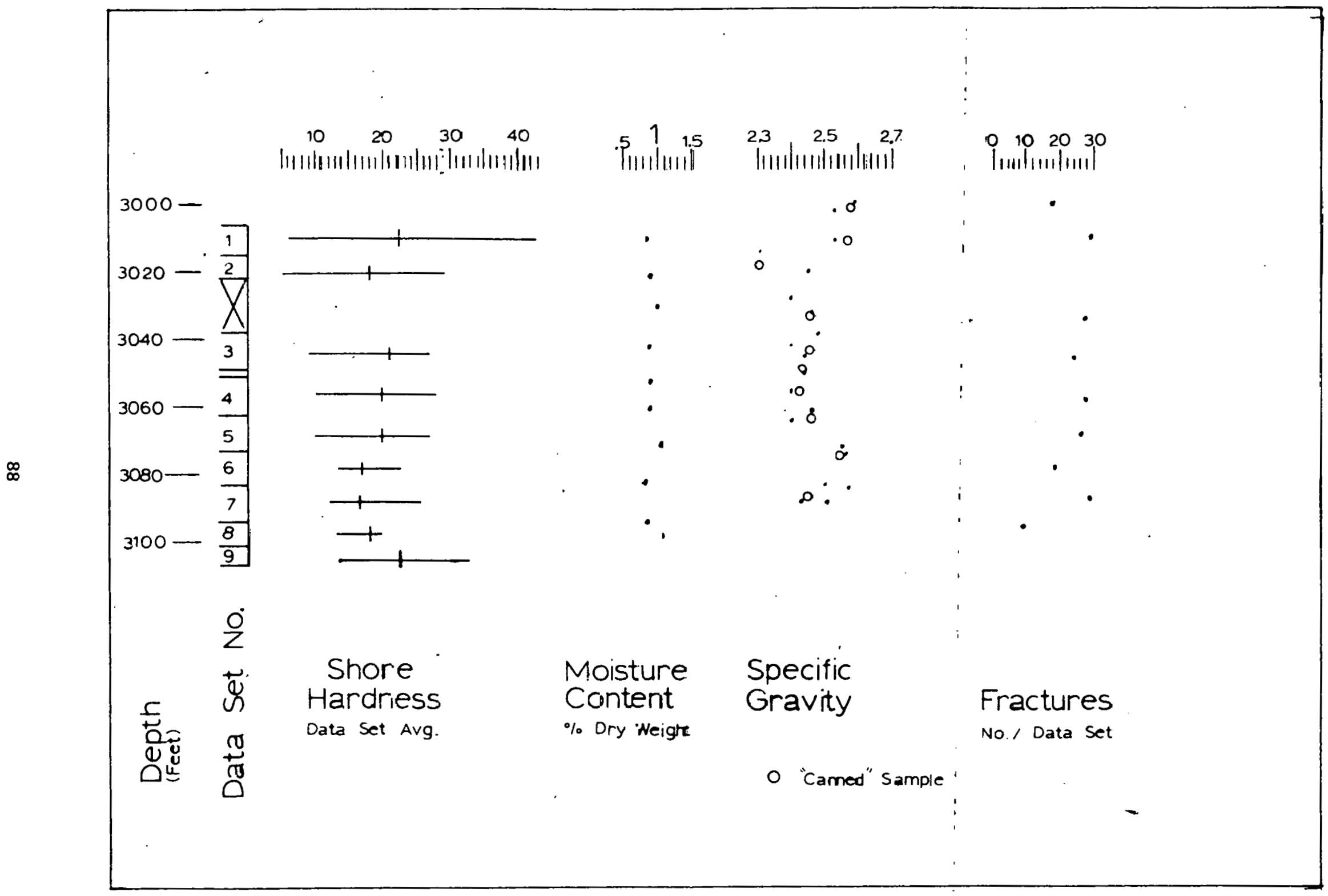

Fig. 22. Index properties, D2IL core. 


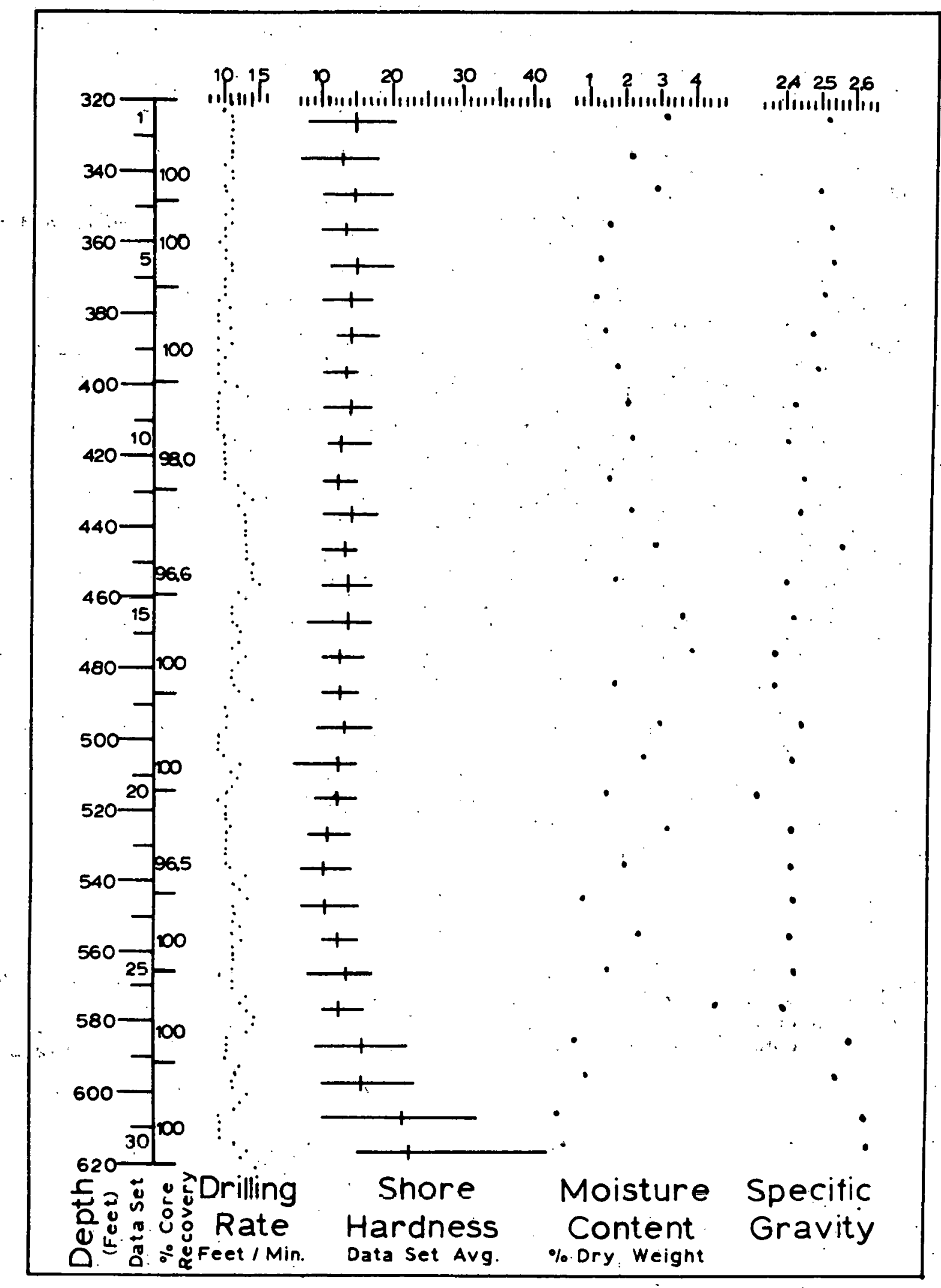

Fig. 29. Index properties, 04IL core. 


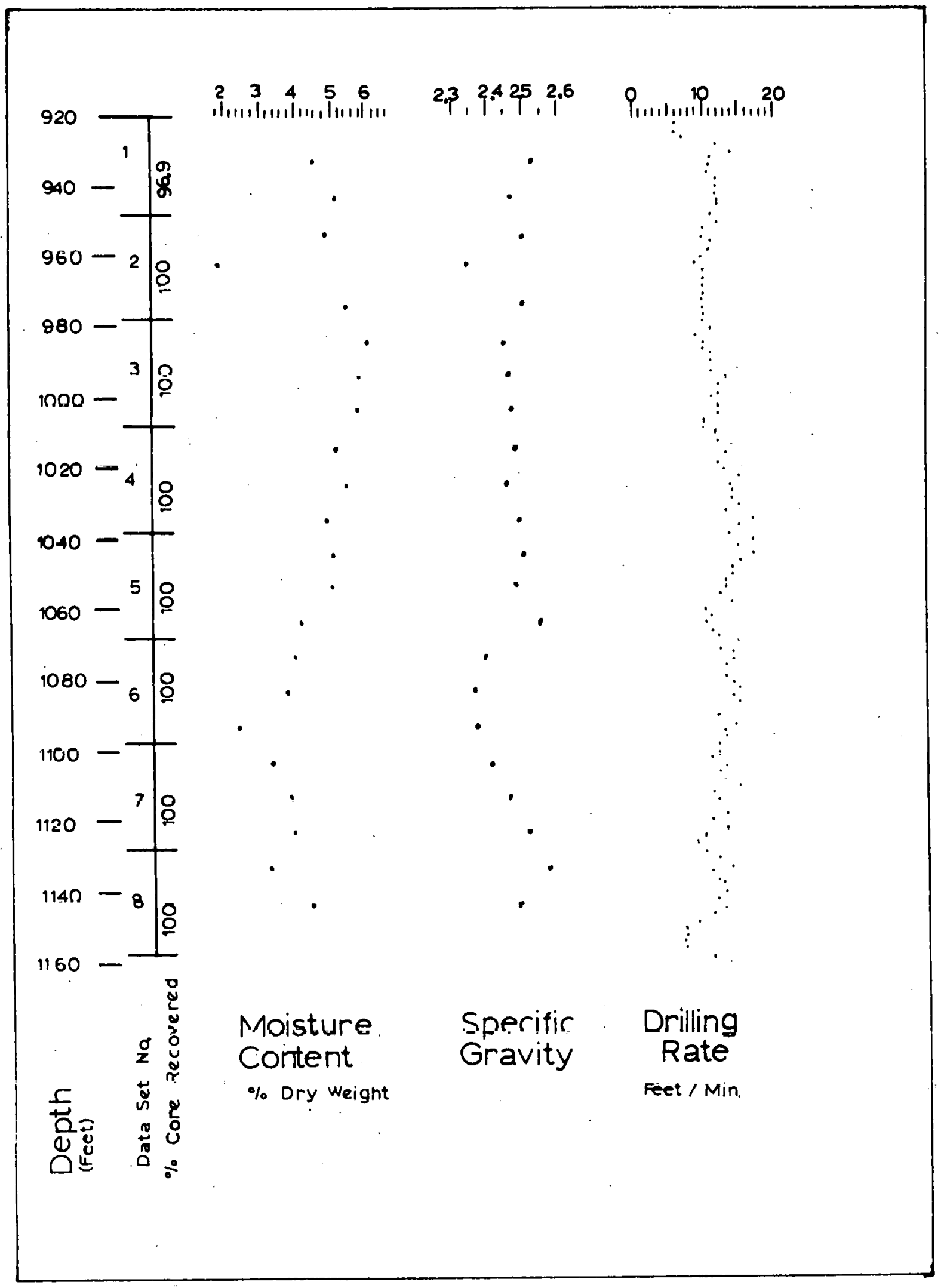

Fig. 30. Index properties, 06IL core. 


\title{
IVG. Mineral resources evaluation system
}

\author{
L. H. Van Dyke
}

\section{SCOPE AND PURPOSE}

The purpose of this project is to develop a Mineral Resources Evaluation System (MINERS) which w111 store all the data related to the Illinois State Geological Survey studies of the Devonian black shale of the Illinols Basin. MINERS will retrieve, process, and display these data. MINERS is a batch system designed to run on an IBM $360 / 75$.

\section{ACCOMPLISHMENTS}

(1) A programmer was hired.

(2) MINERS system was designed. fit into MINERS.

(3) Programs already in use in the Survey information system were

(4) Programs st111 needed to be written were determined.

(5) File generation and maintenance programs were fit into MINERS and programs were debugged. Testing is in progress.

(6) Classification grid and line drawing capabilities were begun to be added to numerical surfaces routines.

\section{METHODS}

MINERS is a comprehensive data handling system oriented toward evaluating mineral resources. Four main areas of data handling are incorporated into the system and are designed to give complete processing of a data item from its entry into a file to its final display on a map, overlay, graph, printout, or as part of an interpretation. These primary areas are: (1) file generation and maintenance; (2) retrieval of data; (3) a numerical surfaces package (GEOMAPS) that provides numerical surface approximation, intersurface integration, intersurface operations among as many as three surfaces, and intrasurface operations; and (4) the display of data on maps and. overlays through use of ILLIMAP.

The file generation and maintenance programs have been designed to handle any data item pertaining to a bore hole that is gathered or generated during geologic research. Inasmuch as there is a wide divergence in types of data, the file generation programs must be able to keep track of a large 
number of data items. Because fast and economic retrieval of data is desirable, the files generated must be easily and quickly accessible, and only those data items which are referenced in the retrieval request should be searched. The files should allow each user to design his file in any format so that only those data items a researcher needs to record and wants to work with are in his file. Inasmuch as a researcher may, and usually does, want to work with data other than his own, the files must also be created in such a way that all data items belonging to a bore hole or other geographic location can be tied together. Some data items will have more than one value at a single geographic location, as, for example, when the same tests are run on successive intervals of a core. The file generation programs must keep track of all these values and be able to tie together all data applicable to any particular depth interval. MINERS will do all of the above.

Although MINERS io designed to handle primarily hore hole data, other data can also be accomodated. In most cases, however, bore hole data will be filed. 'l'wo types of dala flles have been ereated: (1) an all-inclu= sive file (ISGS Basic Data File) of 35 data Ltents ful every boring in the state; and (2) segregated files (ISGS Secondaryfiles) that contain data items gathered by various researchers. The Basic Data File is a fixed format file and is organized by county within the state. Although to date only Illinois data have been incorporated in this file, data from any state can be filed. Each record in this file contains a unique bore holc number (the API number, ten digits in length, of which the first two are the state code) which identifies every data record. This unique number stays with any data items in the various Secondary files so that during retrieval, data can be identified with the correct interval of the correct boring. It is not necessary, as we are doing in Illinois, to include every bore hole in the state in the Basic Data File, but it is necessary to include in this file every bore hole or geographic location for which any data are entered in Secondary Files. The Basic Data File serves as a dictionary of borings for which there are data entered somewhere within the data base.

Secondary files contain only those data items on a boring that a researcher wants in the file. These files are kept small (Insofar as the number of data items are concerned) in order to limit the search to as few data items as possible during retrieval. Therefore, these files are usually made up of closely related items. A Sccondary File is created by preparing a description of the input data and encoding it along with the data that are to be put into the file. At this point a Vescripeion File, which contains the length of each field in the Secondary File and the sequence of data items from left to right along a rccord, and a Secondary File are created. Any addition, deletion, correction, retrieval, or access of data in a Secondary File is then easily accomplished because the Description File contains the format of its Secondary file. Hence, the user needs to know unly the unique name of any data item to be processed. MINERS can locate the data. During retrieval, only those Secondary Files which contain the data items necessary to be queried are used, thereby speeding up the relrieval step.

The retrieval portion of MINERS is designed to allow English language words in the retrieval request. Each data item in the data base will have a unique name. At the time a Secondary file is created, a unique name will be given to each data item that goes in the file. The unique name is also put in a Unique Name File that contains all the unique data item names in the entire 
system, along with the location of the Description File that contains that particular data item. The English language words in a retrieval request include, along with others, the unique names of the data items with AND or OR operations between data items, and LESS THAN, EQUAL TO, and GREATER THAN operations on individual data items. The retrieval programs will translate the unique name used in the retrieval request to its location in the file in which it is located. First, a rapid search of the Unique Name File (which is organized alphabetically) will locate the Description File. The Secondary File and location within the file are determined from the Description File. When the retrieval conditions are met, a list of API numbers is the result. These numbers designate all the borings in the entire data set that have information meeting the retrieval conditions and allow the user to access any data item in any file that pertains to those bore holes as retrieval output.

Retrieval output can be to a printer; to a save file, in which case the user supplies the unique names of data items to be saved; to a file for processing in GEOMAPS, in which case certain information must be supplied by the user; for input to ILLIMAP; or combinations of these. MINERS allows one or several output files to result from one retrieval run. The file of unique well numbers may be saved if additional output files would be desired sometime in the future based on a particular retrieval run.

GEOMAPS is a package of mapping programs based on the IBM package "STAMPEDE." IBM personnel completed this package in 1968, but as of 1974, IBM no longer supported it. We obtained the routines and altered them to link with ILLIMAP, to work with special files, and to produce results that were mineral-resource oriented. GEOMAPS functions include: (1) numerical surface approximation (weighted least squares, finite difference techniques); (2) trend surface analysis (8th order is maximum); (3) isopaching; (4) intersurface integration (calculation of volumes and areas); (5) intersurface operations (addition, subtraction, multiplication, or division among as many as three surfaces); and (6) intrasurface operations (manipulation of surface).

I'wo additional capabilities which are being added to this portion of MINERS are a classification grid and the ability to store, retrieve, and process line data. In order to give MINERS the capability of using data that have already been interpreted (such as contour lines, overburden line, outline Pennsylvanian subcrop, etc.), and line data that divides classes of information (Class I reserves from Class II reserves, soil types, etc.), a method of identifying, storing, and retrieving values shown by lines is being added to MINERS. It is essential in most mineral studies to divide areas into various classes of reserves or grades of ore, or into areas where the mineral is absent or cannot be extracted. These data are generally identified by lines. MINERS will create line files, separate from the filing scheme discussed earlier (Basic Data File, Secondary Files, etc.), that will store line data by type and retrieve the lines when needed. Two files will be created. One will act as a dictionary and will contain a line identifier, the end points of the line, and its location in the master file. The master file will be the repository for all the $\mathrm{X}-\mathrm{Y}$ pairs of individual points along the lines.

The classification grid is our attempted solution to a problem that was encountered in an earlier use of GEOMAPS. The need arose to classify portions of a numerical surface according to more than two values (depth, numerical). The classification grid is a routine that will assign class values to grid intersections. 
ILLIMAP is a computer-based map drawing system that will draw base maps and/or overlays of any portion or the entire state of Illinois at any scale. (Swann et al., 1970). Furthermore, any data point in Illinois that is described in legal notation can be automatically converted by ILLIMAP to a map location and plotted on a map. That is, any data point described by section-township-range-whether described as quartering of a section down to $2 \frac{1}{2}$ acres (quarter-quarter-quarter-quarter), measurement in feet from the section lines, or measurement in feet from any of the interior quarter lines-can be converted to ILLIMAP co-ordinates without a separate processing run. ILLIMAP locations are accurate to within approximately $200 \mathrm{ft}$ of the actual ground postition.

ILLIMAP, the key to MINERS, has the following capabilities: (1) accurately locates geographically any data a researcher desires to use, even Iine data; (2) allows use of maps of only the area a researcher is interested in, at any desired scale; and (3) permits mapping at a level of accuracy superior to many drafted bases. These capabilities give a wide range of data processing and display options. Because the Lambert conformal conic projection is used in ILLIMAP, individual maps of the same scale drawn by ILLIMAP will always fit together without distortion. Maps can be drawn using other projections if desired.

ILLIMAP was created by digitizing every section corner in the state of Illinois, every county boundary, and the state boundary from USGS topographic sheets. Seven-and-one-half minute quadrangles were used where available, and 15-minute quadrangles were used elsewhere. The accuracy of a 15minute quadrangle is $100 \mathrm{ft}$, and that of a $7 \frac{1}{2}$-minute quadrangle, $40 \mathrm{ft}$. After digitizing a quadrangle and converting the data to Lambert Feet, we drew a base map of the quadrangle and overlaid it on the quad to check the accuracy of all section lines and boundaries. If the ILLIMAP lines were within $200 \mathrm{ft}$ of the lines on the topographic sheet, we accepted the values. With all the compensating errors possible in construction of the USGS sheets and in our digitizing, we belleve our base maps to be accurate to within $200 \mathrm{ft}$ of the actual ground position.

\section{RESULTS}

The MINERS project combines several individual operations that have been under development at the Illinois State Geological Survey. Each of the parts works as originally designed. Making them work together as à páckage, however, has proven more difficult than originally expected, prïmarily because the ISGS programswere designed for a specific set of conditions: namely, to handle data in Illinois, to include all the borings in the state, and to fit an API numbering system different from all other states. If MINERS is to handle data from states other than Illinois and store repetitive values at several intervals in a boring, the original file design is inadequate.

File generation and maintenance are being restructured along the lines discussed under METHODS. The earlier efficient but rather complex file generation and bookkeeping programs are being selectively discarded. Inasmuch as we try to put packages of programs together in a modular fashion, about onethird of the earlier routines will be saved and used. Files that have already been created using our earlier system will need only minor revision to fit the 
present concept; hence programming is the major thrust needed to complete this portion of MINERS.

Retrieval was one of the first portions of MINERS to be developed. Several months ago, the differences between the ISGS information system and the requirements for ERDA data and use, and thus the need for a new approach to retrleval, became apparent. A new retrieval approach has been designed and about two-thirds programmed, and parts of it are already in use. This program, QUAD, is much simpler and more easily converted to interactive retrieval than is the former method. Programing on QUAD will be delayed until file generation and maintenance is finished.

GEOMAPS does not require any restructuring to handle ERDA data. Providing for line files and for use of a classification grid, as mentioned in the original proposal, still remains the primary task. Design work is complete, and about one-third of the programming has been finished. No testing of this programing has been attempted to date. We are still dissatisfied with the contouring program included with the STAMPEDE package and will eventually change it, but whether we will have time to change it before completion of this project is questionable.

ILLIMAP has been in use for about 7 years and has been well tested. It has been 1inked to GEOMAPS for about 2 years; hence, the amount of programming needed to $\mathrm{flt}$ it into MINERS is expected to be only moderate. Hundreds of maps have been produced using ILLIMAP, probably close to one hundred of them in conjunction with GEOMAPS.

\section{DISCUSSION OF RESULTS}

Although much programing and testing still lies ahead, we expect to complete MINERS on schedule. The rather extensive changes being made to MINERS should result in a powerful and useful mineral study and evaluation system. But this system could be made even more useful by changing 1 ts mode of operation.

MINERS, a batch-orfented system designed to run on an IBM $360 / 75$, will not run on any other computer without considerable reprogramming. Batch processing means that the system is used by punching a deck of control cards, reading them through a card reader with or without a data deck, waiting until the computer is ready to process the job, and having the results returned. The turn-around on such a job will be from several minutes to several hours, or even days, depending on work load, type of job run, and other constraints applied by the service center. For example, a disk pack or two will most likely have to be mounted on a disk drive before a job can be processed, since the data needed for a job are seldom already waiting on a disk drive. If time Is of little consequence, this restraint is not bothersome; however, frequently the researcher wants quick results in order to proceed to the next step, or more than one individual desires to use the data base at the same time, an event quite 11kely once significant amounts of data on the black shale project are in MINERS. One satisfactory solution to these problems is to use timesharing equipment and an interactive operating system.

MINERS can be converted to a time-sharing, interactive system that w111 allow a large number of users slmultaneous access to the same data base. 
Using cathode ray tube and/or printer-type terminals at locations throughout the country, researchers could obtain almost instantaneous answers to their inquiries. Group IIIG is developing programs that will provide for interactive processing of their data, to be used primarily for data entry, correction, and retrieval. The purpose is to get away from the batch system time delay and also to allow an Investigator to enter and correct data by following a question-and-answer procedure.

MINERS is expected to be a powerful system for use in Illinois. Most of the system can be used to process data from outside Illinois, but the best parts of the system are limited to use in Illinois, since ILLIMAP can draw base maps and plot data thereon for Illinois only. The task of extending MINERS to areas outside Illinois calls only for extending the geographic base of ILLIMAP into whatever area or areas are desired. However, if the mapping capabilities provided by ILLIMAP are not needed outside Illinois, MINERS can be used for any region of the United States. File generation and maintenance and retrieval. from the files can be done for any state using the unique API well number to store and locate data. It makes no difference to the syscem which state code appears in the appropriate columns; the data belonging. to a boring will be properly tagged and quickly located during retrieval. If $X-Y$ coordinates of the data are obtained by some means and furnished with the data, most of the GEOMAPS package can also be used.

\section{REFERENCE}

Swann, D. H., P. B. DuMontelle, R. F. Mast, and L. H. Van Dyke, 1970, ILLIMAPA Computer-Based Mapping System for Illinois: Illinois State Geological Survey Circular 451; 24 p. 


\title{
IC. Quantitative determination of major, minor, and trace elements in Eastern U.S. shales
}

\author{
J. K. Frosi, G. B. Oreher, and J. K. Kuhn
}

\begin{abstract}
SCOPE AND PURPOSE
$\therefore$ At least 49 major, minor, and trace elements in 900 shale samples, which are representative cross-sections of the cores taken, will be analyzed. ... Determinations included will be organic and mineral carbon; total hydrogen; pyritic*, sulfate*, and total sulfur; total nitrogen; exchangeable cations $(\mathrm{Ca}, \mathrm{Na}, \mathrm{K}, \mathrm{Mg})$; and base exchange capacity. Other elements observed during $::$ normal routine analysis will also be reported. The data generated will be . . : used to evaluate (1) the potential economic importance of trace element concentrations in organic-rich shales; (2) new geochemical exploration techniques for natural gas; (3) trace element enrichment in shale organic matter; (4): the occurrence of heavy metal sulfides in shale; (5) potential catalytic effects of trace elements on shale pyrolysis yields; and (6) potential disposal prob-. lems.
\end{abstract}

\section{ACCOMPLISHMENTS}

Methods have been developed for determining major, minor, and trace elements in core samples of Devonian Shales. These include instrumental neutron activation, direct-reading and photographic optical emission, X-ray fluorescence, ion-selective electrode, and wet chemical procedures. Analytical results from this study and selected data reported in the literature for other shales are given in this report.

\section{METHODS}

All shale samples were ground to pass -100 mesh and dried at $105^{\circ} \mathrm{C}$.

Instrumental neutron activation analysis (NAA)

The method was the same as that used for the analysis of lake sediments as described in Kothandaraman et al. (1977). Gamma-ray counting was done on either of two $\mathrm{Ge}(\mathrm{Li})$ detectors, one a $55 \mathrm{~cm}^{3}$ detector with resolution of $2.5 \mathrm{keV}$ (FWHM) at $1332 \mathrm{keV}$, efficiency of $10.1 \%$ and peak/Compton ratio of 30.5 at $1332 \mathrm{keV}$; the other having an $86.9 \mathrm{~cm}^{3}$ crystal with resolution of 1.9 $\mathrm{keV}$ (FWHM) at $1332 \mathrm{keV}$, efficiency $14.5 \%$ and peak/Compton ratio of 42 at that energy. Each detector was connected to a 4096-channel analyzer.

\footnotetext{
*Where total sulfur exceeds $0.5 \%$.
} 
Sample weights were about $0.3 \mathrm{~g}$. Irradiations to determine shortlived isotopes were for $10 \mathrm{~min}$ at a flux of $1.4 \times 10^{12}$ thermal neutrons $\mathrm{cm}^{-2}$ $\sec ^{-1}$ in the Advanced TRIGA reactor at the University of Illinois. Two-hr irradiations were done on samples on which measurements of isotopes with intermediate and long half-lives were to be made.

Elements sought were: antimony, arsenic, barium, bromine, cerium, cesium, chromium, cobalt, dysprosium, europium, gadolinium, hafnium, indium, iron, lanthanum, lutetium, manganese, molybdenum, neodymium, potassium, rubidium, samarium, scandium, selenium, silver, sodium, strontium, tantalum, terhilum, thorium, tungsten, uranium, ytterbium, zinc, and zirconium.

\section{Optical emission spectroscopy}

Tn avnid detrimental matrix effects caused by organic compounds, a portion of each shale sample was oven-dried at $110^{\circ}$ and ashed at $b 00^{\circ} \mathrm{C}$. The procedure was the same as that for the preparation of high-temperature cual ash described in Ruch et al. (1974). The ashed shale sample was cooled from $500^{\circ} \mathrm{C}$, weighed, and ground with agate mortar and pestle to a fine, homogeneous powder. Concentrations determined by spectroscopic analyses were calculated to values in moisture-free whole (unashed) shale.

\section{Preparation of synthetic shale standards}

A set of synthetic standards was prepared for use in determining trace element concentrations of shales. The synthetic standard matrix was prepared using the mean values (table 13) of the concentrations of the major elements in the shale samples S00001 through S00032 determined by X-ray fluorescence spectrnmetry.

Alumina and silica "Spex Time Saver Standards" (Spex Industries, Inc., Metuchen, $\mathrm{NJ}$ ) containing 1000, 333, 100, and 33 parts per million of 49 different elements were added to the syuthetic matrix in the same proportion $\left(4.90: 1, \mathrm{SiO}_{2}: \mathrm{Al}_{2} \mathrm{O}_{3}\right)$ as its $\mathrm{SiO}_{2}: \mathrm{Al}_{2} \mathrm{O}_{3}$ ratio to prepare standards containing $100,33,10,3.3$, and $1.0 \mathrm{ppm}$ of the 49 elements. To make 1000 and $330 \mathrm{ppm}$

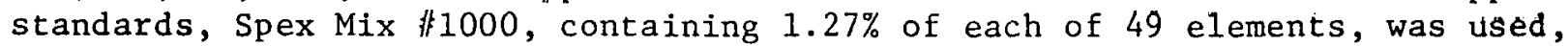
along with silica and alumina in the appropriate ratio. The constituents of each standard and the weights used are given in table 14. To ensure homogeneity, each standard mixture was thoroughly ground w1th a mullite mortar and pestle under absolute ethanol.

\section{Photographic optical emission spectroscopy (UE-P)}

Forty mg of sample was mixed with $10 \mathrm{mg}$ of spectroscopically pure barium nitrate and $150 \mathrm{mg}$ of National brand SP-2X graphite in a polystyrene vial .5 in. in dlameter and 1 in. in depth, containing two methacrylate balls .5 in. In diameter. The vial was agitated in a Wig-L-Bug mixer for $1 \mathrm{~min}$. Twenty $\mathrm{mg}$ of the mixture was taken for electrode charge. Analyses were made using the operating parameters given in table 15, for the elements listed in table 16. The emission lines listed in table 16 are those currently used; some of the IInes used in early analyses proved to have interferences. 
TABLE 13-CONCENTRATION OF MAJOR AND MINOR ELEMENTS IN SHALE STANDARD MATRIX

\begin{tabular}{cc}
\hline Constituent & Concentration(\%) \\
\hline $\mathrm{SiO}_{2}$ & 64.53 \\
$\mathrm{Al}_{2} \mathrm{O}_{3}$ & 13.16 \\
$\mathrm{CaCO}_{3}$ & 6.03 \\
$\mathrm{~K}_{2} \mathrm{CO}_{3}$ & 6.18 \\
$\mathrm{Na}_{2} \mathrm{CO}_{3}$ & 1.70 \\
$\mathrm{Fe}_{2} \mathrm{O}_{3}$ & 4.97 \\
$\mathrm{TiO}_{2}$ & .79 \\
$\mathrm{MgO}$ & 2.64 \\
\hline
\end{tabular}


TABLE IL-COMPOSITION JF STANDARDS FOR SPECTROSCOPIE ANALYSTS OF SHALES

\begin{tabular}{|c|c|c|c|c|c|c|c|}
\hline $\begin{array}{l}\text { Wt, of } \\
\text { synthetic } \\
\text { matrix }\end{array}$ & $\begin{array}{l}\text { Concentrazion } \\
\text { of trace } \\
\text { elements in } \\
\text { Spex Time Saver } \\
\text { Standards (ppm) }\end{array}$ & $\begin{array}{l}\text { Wt. of } \mathrm{SiO}_{2} \\
\text { Spex Time } \\
\text { Javer } \\
\text { Standard } \\
\text { (mg) }\end{array}$ & $\begin{array}{l}\text { Nt. of } \mathrm{Al}_{2} \mathrm{O}_{3} \\
\text { Spex Time } \\
\text { S.aver } \\
\text { Siandard } \\
\text { (ng) }\end{array}$ & $\begin{array}{l}\text { Wt. of } \\
\text { Spex } \\
\# 1000 \\
\text { Mix } \\
\text { (mg) }\end{array}$ & $\begin{array}{l}\mathrm{SiJ}{ }_{2} \\
(\mathrm{mg})^{2}\end{array}$ & $\begin{array}{l}\mathrm{Fil}_{2} \mathrm{O}_{3} \\
\text { (mg) }\end{array}$ & $\begin{array}{l}\text { Concentratior } \\
\text { of trace } \\
\text { elements } \\
\text { in final } \\
\text { srandard (ppm) }\end{array}$ \\
\hline .90000 & & & & 79 & 17.4 & 3.6 & 1000 \\
\hline .90000 & & & & 26 & 62 & $\therefore 2$ & 330 \\
\hline .90000 & 1000 & 83 & 17 & & & & 100 \\
\hline .90000 & 333 & 83 & 17 & & & & 33 \\
\hline .90000 & 100 & 83 & 17 & & & & 10 \\
\hline .90000 & 33.3 & 83 & 17 & & & & 3.3 \\
\hline .90000 & 10.0 & 83 & 17 & & & & 1.0 \\
\hline
\end{tabular}




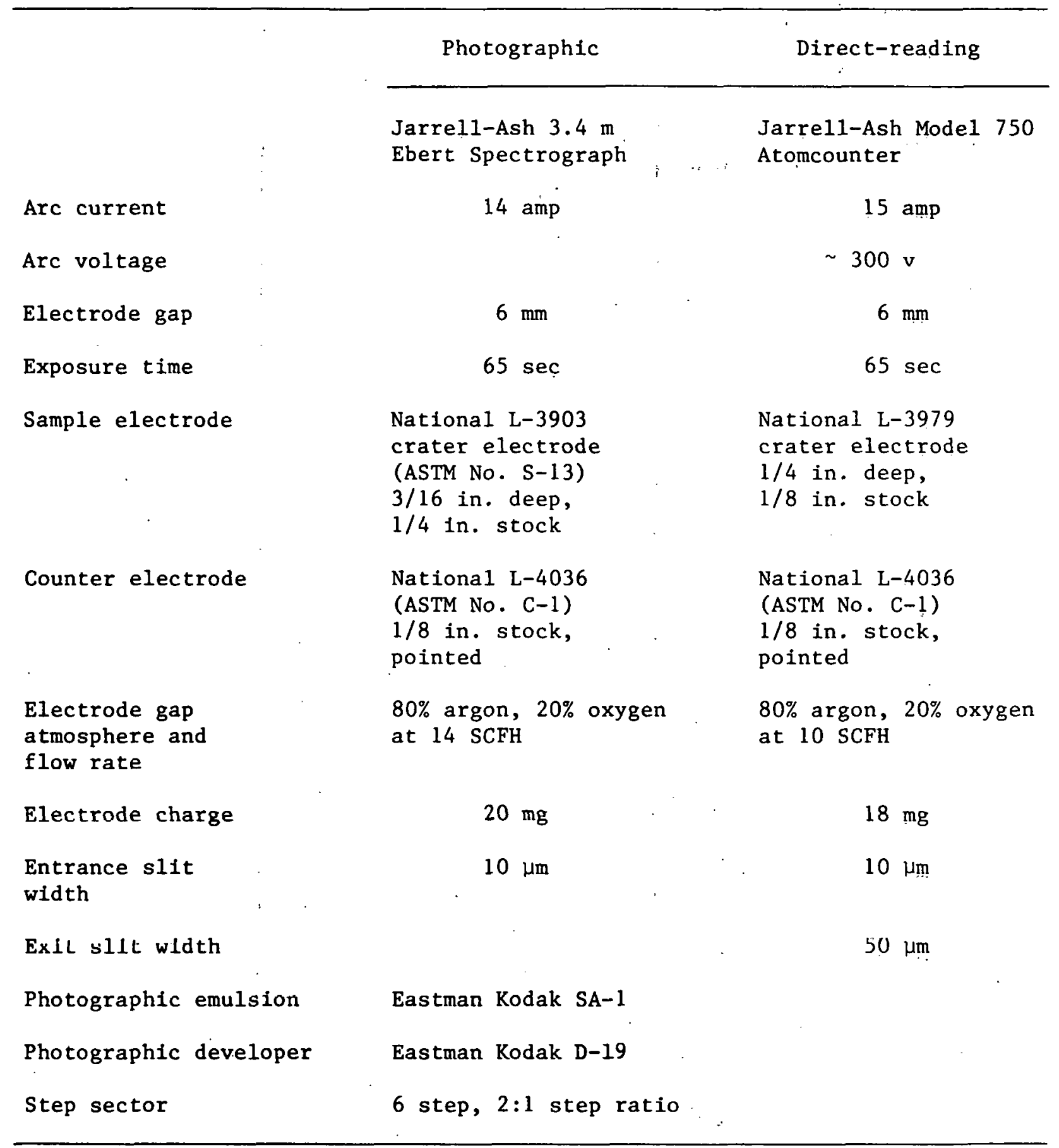


TABLE 16-ELEMENTS DETERMINED BY OPTICAL EMISSION SPECTROSCOPY. AND EMISSION LINES DETECTED

\begin{tabular}{|c|c|c|}
\hline \multirow[b]{2}{*}{ Element } & \multicolumn{2}{|c|}{ Wavelength (A) } \\
\hline & Photographic & Direct-reading \\
\hline $\mathrm{Be}$ & 3131 & 2349 \\
\hline B & - & 2498 (2nd \\
\hline$C r$ & 2843 & 42.54 \\
\hline $\mathrm{Co}$ & 3454 & 3454 \\
\hline $\mathrm{Cu}$ & 3274 & 3274 \\
\hline Ge & 2651 & 2651 \\
\hline $\mathrm{Pb}$ & 3683 & - \\
\hline $\mathrm{Mn}$ & 2801 & - \\
\hline Mo & - & 3170 \\
\hline $\mathrm{Ni}$ & 3493 & 3415 \\
\hline $\mathrm{Ag}$ & 3382 & $=$ \\
\hline $.5 r$ & - & 4607 \\
\hline Sn & 3034 & 3034 \\
\hline $\mathrm{V}$ & 3118 & 3184 \\
\hline $7 n$ & 3345 & 2139 \\
\hline $\mathrm{Zr}$ & 3397 & 3392 \\
\hline
\end{tabular}


Concentrations were determined from the spectrographic lines on the photographic plates as described in Kothandaraman et a1. (1977, p. 22-23).

\section{Direct-reading optical emission spectroscopy (OE-D)}

The mixture from which $18 \mathrm{mg}$ of electrode charge was taken was composed of $50 \mathrm{mg}$ of shale ash mixed $1: 3$ by weight with a $2: 1: 1$ by weight mixture of SP-2X graphite, sodium chloride, and potassium sulfate (spectroscopically pure Spex Industries, Inc., salts), mixed well in a polystyrene vial as described for the photographic method.

Analyses were performed using the operating parameters given in table 15, for the elements listed in table 16 . Concentrations were calculated from the intensity readings from the spectrometer as described in Gluskoter et al. (1977).

\section{$\mathrm{X}$-ray fluorescence analysis (XRF)}

The fused samples analyzed by the X-ray fluorescence method for major and minor elements were prepared according to the procedure described in Shimp, Leland, and White (1970) except that determinations of $\mathrm{Al}_{2} \mathrm{O}_{3}, \mathrm{SiO}_{2}$, and $\mathrm{MgO}$ were made with a thallium acid phthalate crystal, which gave better sensitivity than the ammonium dihydrogen phosphate and ethylene diamine ditartrate crystals formerly used.

Elements determined were aluminium, calcium, chlorine, iron, magnesium, manganese, phosphorus, potassium, silicon, sodium, sulfur, titanium, and vanadium.

\section{Ion-selective electrode analysis for fluorine}

Fluor ine was determined in shale samples according to the procedure outlined by Thomas et al. (1977) for determining fluorine in clays. The samples ( $100 \mathrm{mg}$ ) were fused with sodium hydroxide. The melt was acidified with sulfuric acid; a citrate-citric acid buffer that also complexes aluminium and iron was added. The fluoride potential was determined with a fluoride ionselective electrode. An aliquot of a standard fluoride solution was added to the solution of sample, and the potential again measured. The fluoride ion concentration was determined from the change of potential.

\section{Other methods of analyses}

Total carbon was determined by combustion of the shale samples in a closed-system furnace as described in Shimp, Leland, and White (1970). Inorganic carbon was determined in shale samples by the common acid evolutiongravimetric method described for use on sediment samples by Shimp, Leland, and White (1970). Organic carbon was calculated from the difference between the concentrations of total carbon and inorganic carbon.

Hydrogen was also determined on the shale samples with the hightemperature combustion method used to determine total carbon. Since all the 
water in the sample was determined in this procedure, the hydrogen values obtained were not indicative of the hydrogen in the organic portion of the shale.

The cation-exchange capacity of the shales was determined by the method of Peech et a1. (1947). The shale sample (5 g) was leached with ammonium acetate to remove exchangeable cations and to saturate the exchange complex with ammonia. Excess ammonia was removed by leaching with ethyl alcohol. The remaining exchangeable ammonia was removed by distillation and determined by titration with hydrochloric acid.

\section{RESULTS}

Onc hundred fifty samples were to be analyzed by October 1, 1977, the end of the tirst year of the concract. By that date 57 anmplos were received for complete analysis and two other samples fon dualysis for major and minor elements only. On hand are 30 "canned" samples from the Henderson County, Illinois, core taken in July and 22 "canned" samples from the Tazewell County, Illinois, core taken in August 1977. It will probably be 2 to 3 months before off-gassing studies are completed on these 52 samples and the samples made available to the analybical section. Additional samples expected in the next six months include lithologic-based samples from the Henderson and Tazewell County cores and samples from well cuttings and chips from cores from the Illinois State Geological Survey archives. These additional samples may approach 50 in number, bringing the total number of samples to about 150 by April 1978.

Analytical results available on the first two cores, 18 samples from the Christian County, Kentucky, core (O1KY) and 19 samples from the Sangamon County, Illinois, core (OIIL) are presented in tables 17 (a,b, and c) and 18 $(a, b$, and $c)$. Results are preliminary and should not be referenced. Several elements were determined by two methods and a few elements by chree meliods. For some, results by a certain method were considered superiur. For example, $\mathrm{X}$-ray fluorescence analysis of iron was considered more accurate than results by neutron activation analysis; the latter method was used only as a check. For other elements, the determinations by two (or three) methods were equally reliable, for example, determinations of chromium and cobalt by neutron activation analysis and the two optical emission methods.

Discrepancies in the rcsults by different methods for chromium, cobalt, manganese, nickel, and several other elements were apparent. The cause of some of the discrepancies was clear; for example, spectral interferences led to erroneous values in photographic optical emisston spectroscopy, and analyses are being redone. Research on the methods to find the source of other discrepancies is being conducted.

\section{DISCUSSION}

Interpretation of preliminary analytical results has not been undertaken because of the paucity of data. A survey has been made of the literature for data on major, minor, and trace elements in black shales. Table 19 is a selected compilation of these data. Concentration values in the table may be 
TABLE 17a-CHEMICAL DATA ON CHRISTIAN COUNTY, KENTUCKY CORE

\begin{tabular}{|c|c|c|c|c|c|c|c|c|c|c|c|c|c|c|c|}
\hline & $\begin{array}{l}\text { SAMPLE } \\
\text { NO. }\end{array}$ & $\begin{array}{l}\text { GEOL. } \\
\text { NO. }\end{array}$ & $\begin{array}{l}\text { DEPTH } \\
\text { (FT) }\end{array}$ & $\begin{array}{l}3102 \\
(x)^{2}\end{array}$ & $\begin{array}{l}A L 203 \\
(x)\end{array}$ & $\begin{array}{l}\text { FE203 } \\
(x) \\
\text { (XRF) }\end{array}$ & $\begin{array}{l}\text { PEAS } \\
\times \text { PEZOZ } \\
\text { (NAA) }\end{array}$ & $\begin{array}{l}M 60 \\
(x)\end{array}$ & $\begin{array}{l}C A O \\
(x)\end{array}$ & $\begin{array}{l}\text { NA AS } \\
\times \text { NAZO } \\
\text { (NAA) }\end{array}$ & $\begin{array}{l}x \geq 0 \\
(X) \\
(X, P)\end{array}$ & $\begin{array}{l}x \quad A S \\
X \quad K a O \\
(N A A)\end{array}$ & $\begin{array}{l}9102 \\
(x)\end{array}$ & $\begin{array}{l}1805 \\
(8)\end{array}$ & $\begin{array}{l}\text { MN } \\
\text { (PPA) } \\
\text { (NAA) }\end{array}$ \\
\hline - & 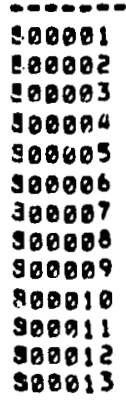 & 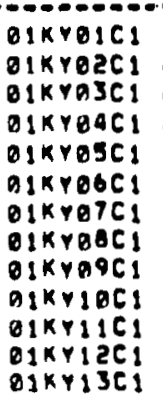 & $\begin{array}{l}1022.2 \\
2191.1 \\
2220.3 \\
2230.2 \\
2240.1 \\
2230.0 \\
2260.3 \\
2270.3 \\
2200.8 \\
2299.7 \\
2299.7 \\
2310.5 \\
2310.8\end{array}$ & $\begin{array}{l}53.2 \\
59.3 \\
59.8 \\
62.8 \\
48.0 \\
59.0 \\
49.9 \\
59.9 \\
51.9 \\
53.8 \\
45.0 \\
51.6 \\
46.8\end{array}$ & $\begin{array}{r}19.1 \\
9.05 \\
9.93 \\
15.0 \\
10.0 \\
16.9 \\
13.5 \\
19.4 \\
11.5 \\
11.5 \\
9.97 \\
0.04 \\
7.07\end{array}$ & $\begin{array}{l}6.85 \\
5.48 \\
7.21 \\
3.91 \\
7.94 \\
9.40 \\
6.28 \\
3.37 \\
3.60 \\
2.64 \\
9.28 \\
3.16 \\
3.89\end{array}$ & $\begin{array}{c}7.43 \\
6.09 \\
7.62 \\
3.69 \\
10.1 \\
5.92 \\
6.33 \\
3.19 \\
9.16 \\
3.97 \\
4.71 \\
3.28 \\
3.62\end{array}$ & $\begin{array}{l}.90 \\
1.21 \\
1.08 \\
1.09 \\
1.69 \\
1.98 \\
1.05 \\
2.18 \\
3.99 \\
2.83 \\
4.85 \\
4.31 \\
9.88\end{array}$ & $\begin{array}{l}.14 \\
1.63 \\
1.60 \\
.56 \\
1.30 \\
1.25 \\
2.26 \\
2.03 \\
4.01 \\
3.69 \\
7.50 \\
8.91 \\
11.7\end{array}$ & $\begin{array}{l}.73 \\
.66 \\
.66 \\
.80 \\
.77 \\
.99 \\
.78 \\
.90 \\
.81 \\
.77 \\
.83 \\
.61 \\
.08\end{array}$ & $\begin{array}{l}3.06 \\
2.98 \\
2.76 \\
4.22 \\
2.61 \\
4.31 \\
3.93 \\
4.23 \\
3.49 \\
3.81 \\
2.99 \\
2.87 \\
2.81\end{array}$ & $\begin{array}{l}3.54 \\
3.09 \\
3.34 \\
9.63 \\
2.80 \\
4.88 \\
4.84 \\
4.89 \\
3.86 \\
9.029 \\
3.08 \\
3.68 \\
3.09\end{array}$ & $\begin{array}{l}.58 \\
.90 \\
.94 \\
.71 \\
.45 \\
.83 \\
.79 \\
.73 \\
.91 \\
.68 \\
.92 \\
.93 \\
.39\end{array}$ & $\begin{array}{r}.18 \\
006 \\
.18 \\
0.81 \\
4025 \\
.87 \\
.09 \\
013 \\
001 \\
.05 \\
019 \\
.15 \\
.19\end{array}$ & $\begin{array}{l}110 \\
310 \\
200 \\
270 \\
410 \\
368 \\
160 \\
100 \\
300 \\
200 \\
400 \\
328 \\
300\end{array}$ \\
\hline $\overrightarrow{\text { ç: }}$ & $\begin{array}{l}500033 \\
908034 \\
900035 \\
500036 \\
300037\end{array}$ & $\begin{array}{l}\text { BIKYOBLI } \\
\text { BIKYIOLI } \\
\text { OIKYIILI } \\
\text { OIKYIRLI } \\
\text { OIKYISLI }\end{array}$ & $\begin{array}{l}2273.15 \\
2287.8 \\
2292.9 \\
2311.1 \\
2312.6\end{array}$ & $\begin{array}{l}55.0 \\
59.3 \\
51.8 \\
49.8 \\
99.8\end{array}$ & $\begin{array}{r}19.5 \\
11.0 \\
10.9 \\
8.97 \\
1.59\end{array}$ & $\begin{array}{l}5.05 \\
2.90 \\
3.02 \\
2.02 \\
3.05\end{array}$ & $\begin{array}{l}5.42 \\
2.72 \\
3.57 \\
2.79 \\
3.24\end{array}$ & $\begin{array}{l}1.82 \\
3.62 \\
3.47 \\
0.25 \\
0.19\end{array}$ & $\begin{array}{r}1.69 \\
9.67 \\
5.58 \\
10.3 \\
9.32\end{array}$ & $\begin{array}{l}.87 \\
.77 \\
.78 \\
.55 \\
.54\end{array}$ & $\begin{array}{l}0.10 \\
3.62 \\
3.53 \\
2.64 \\
2.63\end{array}$ & $\begin{array}{l}9.92 \\
9.19 \\
3.96 \\
3.15 \\
3.89\end{array}$ & $\begin{array}{l}.71 \\
.71 \\
.05 \\
.38 \\
.36\end{array}$ & $\begin{array}{l}.12 \\
.83 \\
.84 \\
.19 \\
.25\end{array}$ & $\begin{array}{l}200 \\
360 \\
330 \\
370 \\
360\end{array}$ \\
\hline & & & & $\begin{array}{l}M N \\
(P P M) \\
(U E=P)\end{array}$ & $\begin{array}{c}V \\
(P P M) \\
(O E-C)\end{array}$ & $\begin{array}{c}V \\
(P P M) \\
(O E=P)\end{array}$ & $\stackrel{s}{(x)}$ & $\begin{array}{c}C L \\
(x)\end{array}$ & $\begin{array}{l}\text { TOTAL } \\
\text { C }(x)\end{array}$ & $\begin{array}{l}\text { ORGANIC } \\
\text { C }(X)\end{array}$ & $\begin{array}{l}\text { INORG, } \\
C(x)\end{array}$ & $\stackrel{H}{(x)}$ & $\begin{array}{l}\text { POTAL } \\
\text { CEC } \\
\text { MEO/1006 }\end{array}$ & $\begin{array}{c}\text { BE } \\
(P P M) \\
(D E-D)\end{array}$ & $\begin{array}{c}\text { OE } \\
(P P M) \\
(O E-P)\end{array}$ \\
\hline & 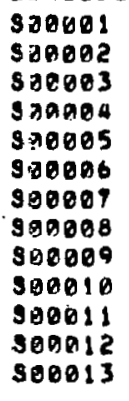 & & & $\begin{array}{l}120 \\
290 \\
220 \\
260 \\
340 \\
310 \\
150 \\
170 \\
320 \\
240 \\
360 \\
360 \\
330\end{array}$ & $\begin{array}{l}160 \\
100 \\
170 \\
159 \\
120 \\
150 \\
-360 \\
190 \\
190 \\
190 \\
190 \\
230 \\
480\end{array}$ & $\begin{array}{l}200 \\
100 \\
169 \\
150 \\
128 \\
150 \\
450 \\
290 \\
190 \\
280 \\
150 \\
240 \\
328\end{array}$ & $\begin{array}{l}2.42 \\
1.84 \\
1.93 \\
.35 \\
2.27 \\
.22 \\
1.79 \\
.93 \\
.62 \\
.64 \\
1.38 \\
1.00 \\
1.18\end{array}$ & $\begin{array}{l}.02 \\
.02 \\
.01 \\
.02 \\
.02 \\
.02 \\
.01 \\
.02 \\
.01 \\
.01 \\
.02 \\
.01 \\
.01\end{array}$ & $\begin{array}{r}14.13 \\
10.86 \\
7.78 \\
2.20 \\
7.01 \\
1.69 \\
12.61 \\
6.00 \\
7.51 \\
1.0 .56 \\
10.16 \\
8.32 \\
10.38\end{array}$ & $\begin{array}{r}14.83 \\
10.29 \\
7.03 \\
1.64 \\
5.81 \\
.66 \\
12.38 \\
5.04 \\
5.39 \\
9.23 \\
7.03 \\
9.67 \\
7.38\end{array}$ & $\begin{array}{r}.18 \\
.97 \\
.75 \\
.60 \\
1.28 \\
1.93 \\
.31 \\
.96 \\
2.12 \\
1.33 \\
2.73 \\
2.65 \\
3.98\end{array}$ & $\begin{array}{l}1.93 \\
1.43 \\
1.27 \\
1.74 \\
.91 \\
.59 \\
1.72 \\
1.29 \\
1.18 \\
1.36 \\
1.98 \\
1.86 \\
.89\end{array}$ & $\begin{array}{l}99 \\
39 \\
47 \\
39 \\
32 \\
73 \\
50 \\
49 \\
33 \\
26 \\
25 \\
17 \\
10\end{array}$ & $\begin{array}{l}3,6 \\
6.3 \\
4.2 \\
3,2 \\
3.8 \\
2.6 \\
2,9 \\
2,03 \\
2.5 \\
2,6 \\
2.0 \\
2.0 \\
2.2\end{array}$ & $\begin{array}{l}3,6 \\
5,0 \\
4,4 \\
5.2 \\
3.4 \\
9.4 \\
5,0 \\
5,2 \\
9.1 \\
3,0 \\
3,0 \\
3,3 \\
3.6\end{array}$ \\
\hline & $\begin{array}{l}308033 \\
500834 \\
300035 \\
380836 \\
300037\end{array}$ & & & $\begin{array}{l}170 \\
310 \\
300\end{array}$ & $\begin{array}{l}260 \\
120 \\
129 \\
229 \\
245\end{array}$ & $\begin{array}{l}230 \\
138 \\
138\end{array}$ & $\begin{array}{r}.09 \\
.42 \\
.76 \\
190 \\
1.02\end{array}$ & $\begin{array}{l}.01 \\
.01 \\
.02 \\
.01 \\
.01\end{array}$ & $\begin{array}{l}8.84 \\
5.65 \\
8.64 \\
8.90 \\
8.93\end{array}$ & $\begin{array}{l}0.82 \\
3.40 \\
6.70 \\
3.79 \\
9.93\end{array}$ & $\begin{array}{l}.02 \\
2.25 \\
1.90 \\
3.11 \\
3.00\end{array}$ & $\begin{array}{l}1.27 \\
.75 \\
1.03 \\
.86 \\
.85\end{array}$ & $\begin{array}{l}46 \\
48 \\
32 \\
18 \\
12\end{array}$ & $\begin{array}{l}0.5 \\
2.9 \\
0.4 \\
2.8 \\
2.0\end{array}$ & $\begin{array}{l}4.9 \\
3,0 \\
4.8\end{array}$ \\
\hline
\end{tabular}


TFBLE 17b-C.AEMICAL DATA ON CHRISTIAN COUNTY, KENEUSYYY CORE

\begin{tabular}{|c|c|c|c|c|c|c|c|c|c|c|c|c|c|c|}
\hline $\begin{array}{l}\text { SAMPLE } \\
\text { N:O. }\end{array}$ & $\begin{array}{l}\text { GEOL. } \\
\text { NO. }\end{array}$ & $\begin{array}{l}\text { DEPYH } \\
\text { (FT) }\end{array}$ & $\stackrel{E}{E}$ & $\begin{array}{l}C R \\
(P P M) \\
(N \perp A)\end{array}$ & $\begin{array}{l}\text { CR } \\
(P P Y) \\
(O E-J)\end{array}$ & $\begin{array}{l}C R \\
(P P M) \\
(O E=F)\end{array}$ & $\begin{array}{l}\text { CO } \\
\text { (PPA) } \\
\text { (NAA) }\end{array}$ & $\begin{array}{l}\text { CO } \\
(P P M) \\
(D E-D)\end{array}$ & $\begin{array}{l}C O \\
(P P M) \\
(O E \rightarrow P)\end{array}$ & $\begin{array}{l}C U \\
(P P M) \\
(O E-D)\end{array}$ & $\begin{array}{l}C L \\
\text { (PFH } \\
\text { (OE-P) }\end{array}$ & $\begin{array}{l}\text { OY } \\
\text { (PPM) }\end{array}$ & $\underset{(P P M)}{F}$ & $\begin{array}{c}G E \\
(P P M) \\
(O E \cap O)\end{array}$ \\
\hline 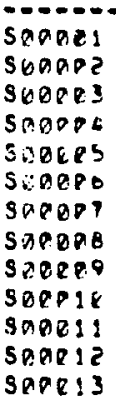 & 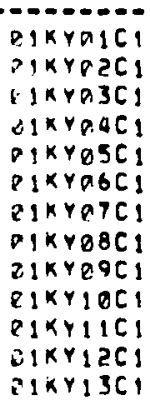 & $\begin{array}{l}1822.2 \\
2191.1 \\
2220.3 \\
2239.2 \\
2240.1 \\
2259.0 \\
2260.3 \\
2279.3 \\
2280.0 \\
2290.7 \\
2299.7 \\
2319.5 \\
2318.8\end{array}$ & $\begin{array}{l}1=0 \\
109 \\
120 \\
200 \\
1<8 \\
250 \\
210 \\
240 \\
2=5 \\
150 \\
1 \in 5 \\
1 \leq 0 \\
110\end{array}$ & $\begin{array}{l}66 \\
57 \\
58 \\
68 \\
62 \\
90 \\
87 \\
109 \\
84 \\
95 \\
64 \\
54 \\
35\end{array}$ & $\begin{array}{l}74 \\
62 \\
65 \\
98 \\
69 \\
189 \\
180 \\
120 \\
99 \\
88 \\
69 \\
56 \\
68\end{array}$ & $\begin{array}{l}60 \\
65 \\
73 \\
1.0 \\
i 0 \\
1.9 \\
128 \\
150 \\
1.0 \\
1.9 \\
60 \\
15 \\
98\end{array}$ & $\begin{array}{l}39 \\
29 \\
23 \\
11 \\
32 \\
12 \\
23 \\
14 \\
11 \\
12 \\
13 \\
11 \\
13\end{array}$ & $\begin{array}{l}46 \\
32 \\
26 \\
12 \\
34 \\
11 \\
29 \\
14 \\
13 \\
12 \\
14 \\
14 \\
14\end{array}$ & $\begin{array}{l}56 \\
38 \\
24 \\
12 \\
23 \\
9.6 \\
26 \\
16 \\
11 \\
11 \\
11 \\
12 \\
10\end{array}$ & $\begin{array}{l}89 \\
60 \\
82 \\
61 \\
10 \\
36 \\
160 \\
140 \\
130 \\
199 \\
139 \\
125 \\
219\end{array}$ & $\begin{array}{l}59 \\
8 ? \\
90 \\
78 \\
72 \\
25 \\
170 \\
200 \\
180 \\
360 \\
190 \\
290 \\
270\end{array}$ & $\begin{array}{r}5.6 \\
9.4 \\
4.8 \\
9.7 \\
17 \\
5.4 \\
6.4 \\
5.6 \\
6.8 \\
6.4 \\
6.8 \\
6.1 \\
7.8\end{array}$ & $\begin{array}{l}648 \\
638 \\
507 \\
998 \\
2925 \\
895 \\
705 \\
885 \\
770 \\
809 \\
865 \\
920 \\
920\end{array}$ & 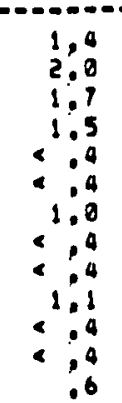 \\
\hline 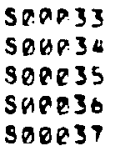 & $\begin{array}{l}\text { IKYOBLI } \\
\text { KIKYIQLI } \\
\text { EIKYIILI } \\
\text { IKYIZLI } \\
\text { BKYIJLI }\end{array}$ & $\begin{array}{l}2273.5 \\
2287.8 \\
2292.9 \\
2311.1 \\
2312.6\end{array}$ & $\begin{array}{l}150 \\
230 \\
325 \\
1 \leq 0 \\
1=0\end{array}$ & $\begin{array}{r}129 \\
75 \\
83 \\
67 \\
71\end{array}$ & $\begin{array}{l}110 \\
75 \\
71 \\
58 \\
61\end{array}$ & $\begin{array}{r}14 \pi \\
31 \\
88 \\
5\end{array}$ & $\begin{array}{l}13 \\
6.8 \\
8.4 \\
9.7 \\
11\end{array}$ & $\begin{array}{l}14 \\
9.1 \\
7.3 \\
14 \\
12\end{array}$ & $\begin{array}{l}12 \\
8,0 \\
12\end{array}$ & $\begin{array}{r}159 \\
69 \\
155 \\
129 \\
119\end{array}$ & $\begin{array}{l}218 \\
180 \\
188\end{array}$ & $\begin{array}{l}6.5 \\
6.0 \\
6.8 \\
6.5 \\
7.8\end{array}$ & $\begin{array}{l}950 \\
875 \\
770 \\
970 \\
860\end{array}$ & $\begin{array}{r}.7 \\
0.4 \\
2.4 \\
\times: 4\end{array}$ \\
\hline
\end{tabular}

\begin{tabular}{|c|c|c|c|c|c|c|c|c|c|c|c|c|}
\hline & $\begin{array}{c}\text { GE } \\
(P F M) \\
(D E=P)\end{array}$ & $\begin{array}{c}P B \\
(P P M) \\
(O E-P)\end{array}$ & $\begin{array}{c}M \cap \\
(P P M) \\
(O E-D)\end{array}$ & $\begin{array}{c}P O \\
(P P M) \\
(N, A A)\end{array}$ & $\begin{array}{c}N I \\
(P P M) \\
(O E \bullet D)\end{array}$ & $\begin{array}{c}N I \\
(P P M) \\
(O E-P)\end{array}$ & $\begin{array}{c}N E \\
\text { (PPM) } \\
\text { (NAA) }\end{array}$ & $\begin{array}{c}\text { SC } \\
\text { (PPM) }\end{array}$ & $\begin{array}{c}A G \\
P F M \\
O E-O S\end{array}$ & $\begin{array}{c}\text { SR } \\
(P P M) \\
(O E=D)\end{array}$ & $\begin{array}{c}9 N \\
(P P M) \\
(O E=D)\end{array}$ & $\begin{array}{c}S N \\
(P P M) \\
(O E-P)\end{array}$ \\
\hline supees & $<18$ & 30 & 180 & $22 a$ & 100 & 189 & 139 & 12 & $<.7$ & 110 & 2.9 & 81.4 \\
\hline soeear & $<1 k$ & 14 & 200 & 190 & 75 & 109 & 98 & is & & i49 & 8 & iis \\
\hline Soppos & $<18$ & 36 & 160 & 150 & 85 & 110 & 90 & 13 & & 190 & .9 & 41.5 \\
\hline sopend & $<11$ & 19 & 4 & 29 & 33 & 42 & 39 & 17 & $<.3$ & 190 & 4.7 & 41.7 \\
\hline 500025 & $<18$ & 26 & 100 & $7 a$ & $B A$ & 87 & 159 & 14 & & .600 & 1.4 & $<1,6$ \\
\hline SBOEe & $<1$ & 11 & Q1 & ND & 23 & 39 & 47 & 19 & $<.3$ & 219 & 4.4 & -1.7 \\
\hline 900807 & $41 \bar{e}$ & 23 & 220 & 240 & 280 & 300 & 309 & 17 & $<.1$ & 259 & 3.8 & $<1.4$ \\
\hline 900280 & $<11$ & 29 & 1.5 & 27 & 80 & 180 & 159 & 20 & .37 & 190 & 5.6 & 15 \\
\hline 500009 & $<11$ & 14 & 3.5 & in & $8 A$ & 120 & 159 & 17 & $<.3$ & 210 & 2.6 & 9.7 \\
\hline 5000.10 & $<11$ & 3 is & $2 A$ & 29 & 129 & 200 & 160 & $1 A$ & $<.7$ & $15 a$ & 3,0 & 15 \\
\hline SEORI! & $<11$ & 33 & 23 & $3 n$ & $9 n$ & 120 & 149 & 25 & $<.1$ & 170 & 3.6 & 4,0 \\
\hline 900A12 & $<11$ & 24 & 39 & $\$ 0$ & 1?ด & 190 & 130 & 19 & 1.3 & 130 & 3.6 & 5,3 \\
\hline 580213 & $<11$ & 14 & 110 & 35 & 200 & 250 & 280 & 13 & & 160 & 3.7 & 0.3 \\
\hline 500033 & $<11$ & 26 & 17 & 24 & 130 & 150 & 120 & $2 a$ & 2.7 & 160 & 5.6 & 11 \\
\hline 300034 & <il & 7.2 & 4. & 30 & 69 & 76 & 62 & 10 & $<.3$ & 179 & 4.9 & 6,1 \\
\hline 500235 & 411 & 11 & 11 & 20 & $16 a$ & 120 & 96 & 16 & $<.3$ & 120 & 5.0 & 6.9 \\
\hline 900036 & 411 & & 36 & ND & 100 & & 120 & 11 & & 160 & 4.2 & \\
\hline SARP & $<11$ & & 39 & 57 & 150 & & $16 \%$ & 12 & & 145 & 4.4 & \\
\hline
\end{tabular}


TABLE 17:-CHEMICAL DATA ON CHRISTIAN COUNTY, KENTUCKY CORE

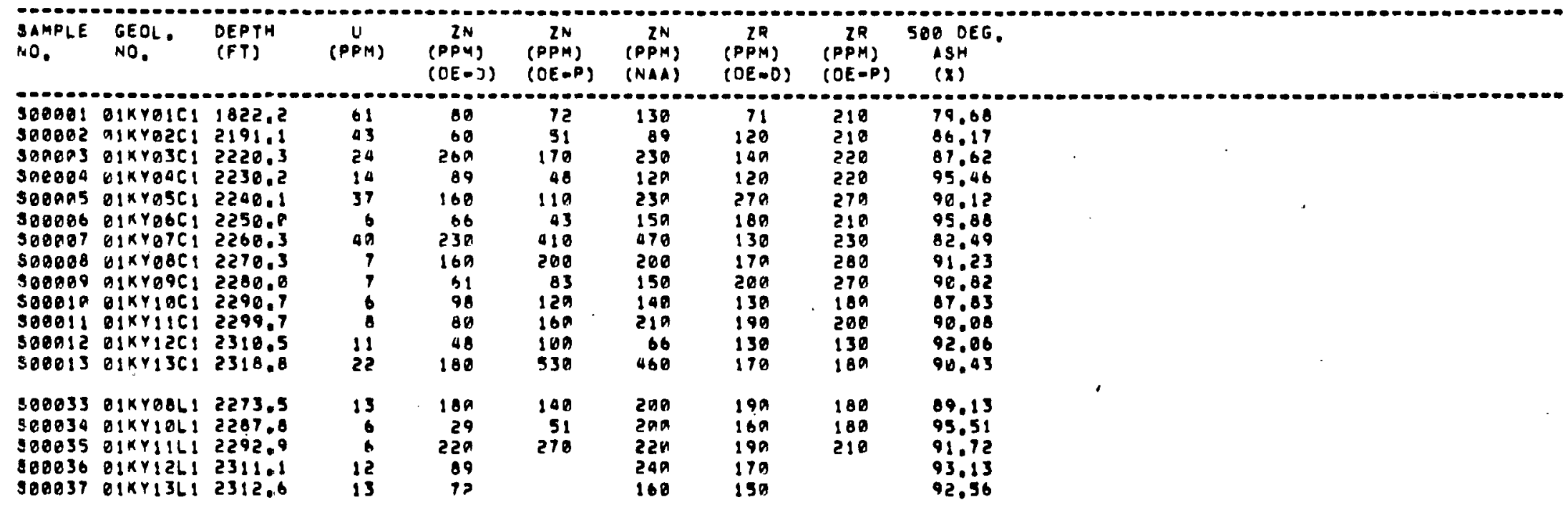

NO - NOT DETECTED 
TABLE 18a-CHEMICAL DATA ON SANGAMON COJNTY, ILIINOIS CORE

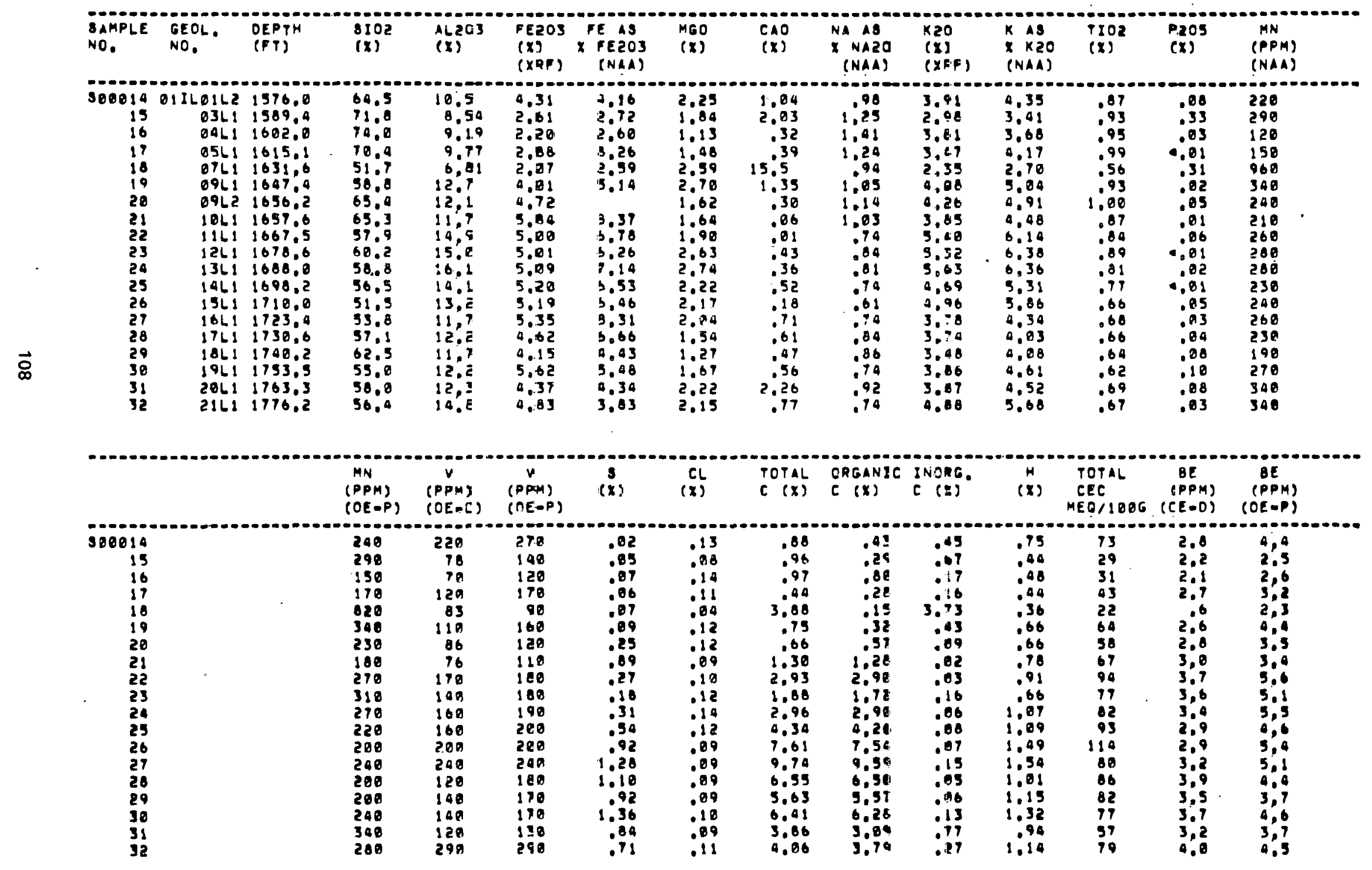


TABLE $13 \mathrm{~b}-$ CHEMICAL DATA ON SANGAMON COUNTY, ILLINOIS CORE

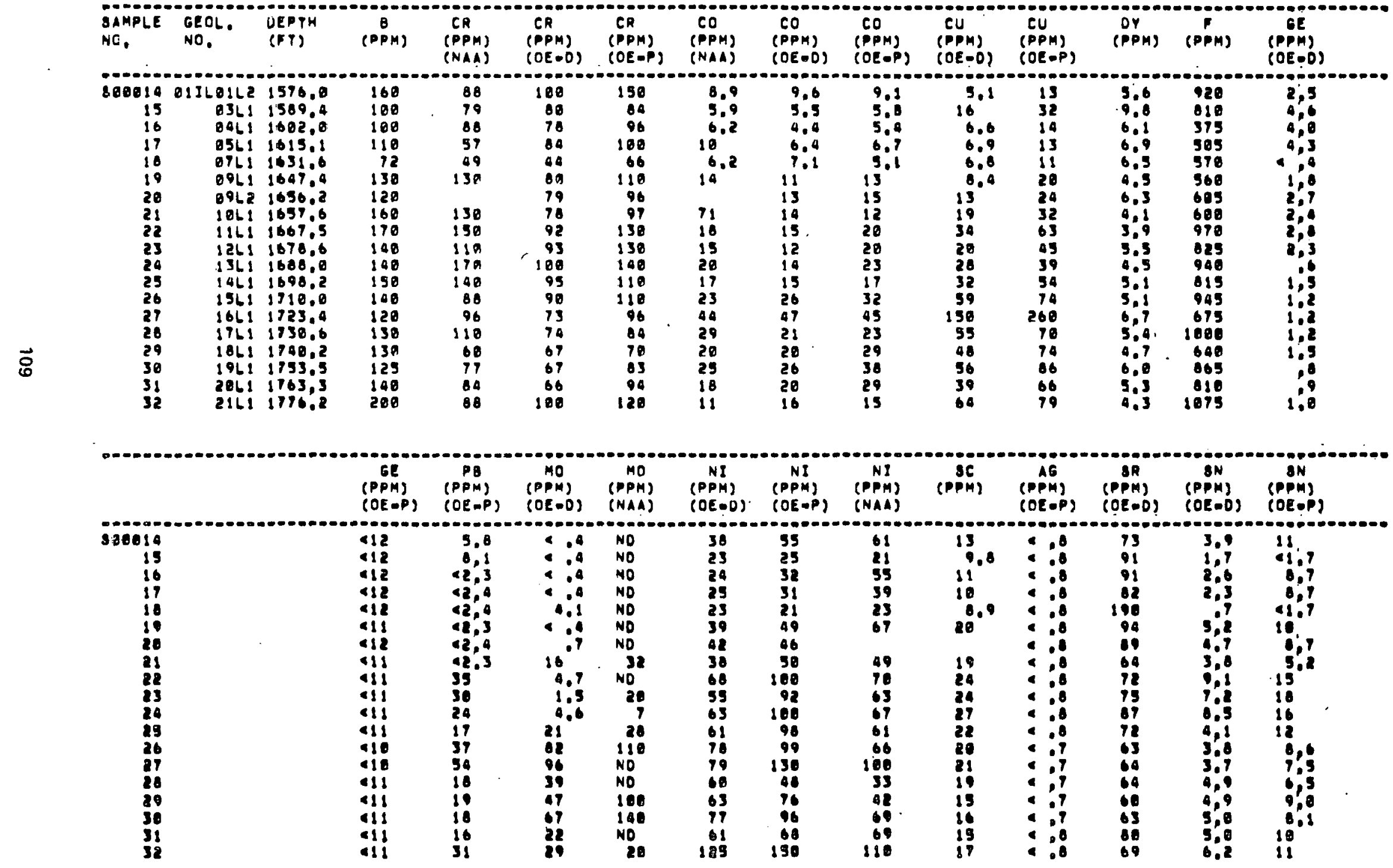


TABLE 18C-CAEMICA DATA ON SANGAMON COUNTY, ILLIHCIS CORE

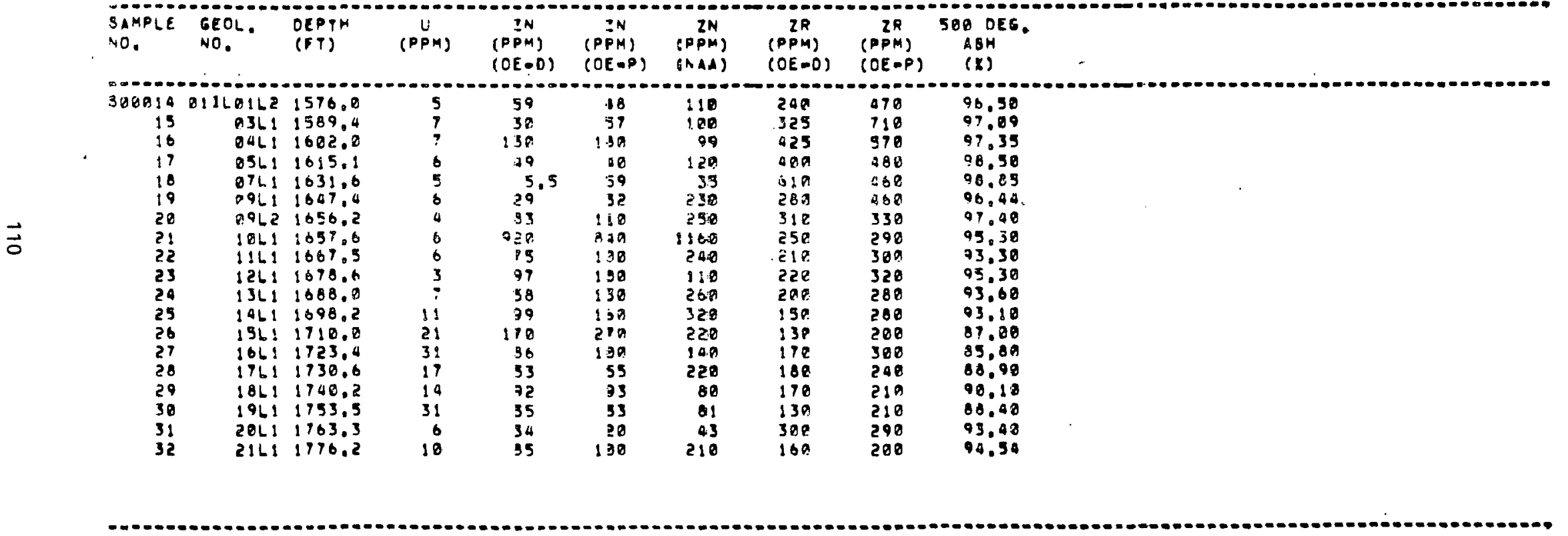

ND NOT OETECTEO 
TABLE 19-SELECTED COMPILATTON OF LITERATURE DATA ON FLEMFNTAL CONCENTRATIONS

IN TIIF. FARTH'S CRUST AND SHALES (values in $\mathrm{ppm}$ )

\begin{tabular}{|c|c|c|c|c|c|c|c|c|}
\hline \multirow[b]{2}{*}{ Element } & \multicolumn{2}{|c|}{$\begin{array}{c}\text { Earth's } \\
\text { Crust }\end{array}$} & \multirow[b]{2}{*}{$\begin{array}{c}\text { Shale } \\
\text { Turekian, } \\
1961\end{array}$} & \multirow{2}{*}{$\begin{array}{c}\text { International } \\
\text { Black Shales } \\
\text { Krauskopf, } \\
1955\end{array}$} & \multirow{2}{*}{$\begin{array}{l}\text { U.S. } \\
\text { Black } \\
\text { Shales } \\
\text { Vine, } \\
\text { lyio }\end{array}$} & \multirow{2}{*}{$\begin{array}{c}\text { Preen River } \\
\text { Shale. } \\
\text { Utah } \\
\text { Picard, } \\
1973\end{array}$} & \multirow{2}{*}{$\begin{array}{l}\text { Chattanooga } \\
\text { Shale, } \\
\text { OK, AR, MO, KA } \\
\text { Landis, } \\
\text { L } 962\end{array}$} & \multirow{2}{*}{$\begin{array}{c}\text { New Albany } \\
\text { Shale, } \\
\text { Kentucky } \\
\text { Louns, } \\
1973\end{array}$} \\
\hline & $\begin{array}{l}\text { Ref. } \\
\text { Tavlor, } \\
1964\end{array}$ & $\begin{array}{l}\text { Ref } \\
\text { Clark } \\
1924\end{array}$ & & & & & & \\
\hline $\mathrm{Ag}$ & 0.07 & & 0.07 & $5-50$ & $<1$ & & $<0.5-2$ & \\
\hline Al & & 81,300 & 80,000 & & 70,000 & 43,000 & & \\
\hline As & 1.8 & & 13 & $75-225$ & & & & \\
\hline $\mathrm{B}$ & $10^{\circ}$ & & 100 & & 50 & 46 & $200-500$ & \\
\hline Ba & 425 & & 580 & $450-700$ & 300 & 350 & $500-1,000$ & \\
\hline $\mathrm{Be}$ & 2.8 & & 3 & 1 & 1 & 1.4 & $1-2$ & \\
\hline $\mathrm{Br}$ & 2.5 & & 4 & & & & & \\
\hline CA & & 36,300 & 22,100 & & 15,000 & & & \\
\hline $\mathrm{Cd}$ & 0.2 & & 0.3 & & & & & \\
\hline $\mathrm{Cl}$ & 130 & & 180 & $5-50$ & & & & \\
\hline Co & 25 & & 19 & $10-500$ & 10 & 56 & $10-200$ & $10-70$ \\
\hline $\mathrm{Cr}$ & 100 & & 90 & $20-300$ & 100 & 64 & $50-100$ & $45-130$ \\
\hline $\mathrm{Cu}$ & 55 & & 45 & & 70 & 54 & $50-200$ & \\
\hline $\mathrm{F}$ & 625 & & 740 & & & & & \\
\hline $\mathrm{Fe}$ & & 50,000 & 47,200 & & 20,000 & 26,000 & & \\
\hline $\mathrm{Ga}$ & 15 & & 19 & 70 & 20 & 21 & $50-100$ & \\
\hline $\mathrm{Ge}$ & 1.5 & & 1.6 & 7 & & & & \\
\hline $\mathrm{Hf}$ & 3 & & 2.8 & & & & & \\
\hline $\mathrm{K}$ & & 25,900 & 26,600 & & 20,000 & 28,000 & & $60,000-110,000$ \\
\hline La & 30 & & 92 & & 30 & 59 & $20-100$ & \\
\hline $\mathrm{Mg}$ & & 20,900 & 15,000 & & 7,000 & 10,000 & & \\
\hline $\mathrm{Mn}$ & 950 & & 850 & & 150 & 337 & $20-100$ & $20-1,070$ \\
\hline Mo & 1.5 & & 2.6 & $10-300$ & 10 & 6.6 & $10-200$ & \\
\hline $\mathrm{Na}$ & & 28,300 & 9,600 & & 7,000 & 15,000 & & \\
\hline $\mathrm{Ni}$ & 75 & & 68 & $20-300$ & so & 28 & $100-500$ & \\
\hline $\mathrm{p}$ & & 1,050 & 700 & & & & & \\
\hline $\mathrm{Pb}$ & 13 & & 20 & $20-400$ & 20 & 23 & $10-200$ & . \\
\hline $\mathrm{Rb}$ & 90 & & 140 & 450 & & & & \\
\hline $\mathrm{Sb}$ & 0.2 & & 1.5 & & & & & \\
\hline Sc & 22 & & 13 & 16 & 10 & 11 & $10-20$ & $8-18$ \\
\hline $\mathrm{Se}$ & 0.05 & & 0.6 & & & & & \\
\hline Si & & 277,200 & 73,000 & & & & & \\
\hline Sn & 2 & & 6.0 & & & & & \\
\hline $\mathrm{Sr}$ & 375 & & 300 & $25-400$ & 200 & 306 & $100-500$ & \\
\hline $\mathrm{Ta}$ & 2 & & 0.8 & & & & & \\
\hline Th & 7.2 & & 12 & & & & & $9-16$ \\
\hline $\mathrm{Ti}$ & 1.1 & 4,400 & 4,600 & & 2,000 & 2,400 & $2,000-5,000$ & $200-500$ \\
\hline $\mathrm{U}$ & 1.8 & & 3.7 & & & & $<10-120$ & \\
\hline $\mathrm{V}$ & 135 & & 130 & $50-2,000$ & 150 & 57 & $100-500$ & $100-450$ \\
\hline$w$ & 1.5 & & 1.8 & & & & & \\
\hline $\mathrm{Zn}$ & 70 & & 95 & $100-1,000$ & $<300$ & & $<70-200$ & \\
\hline $\mathrm{zr}$ & 165 & & 160 & $10-20$ & 70 & 99 & $50 \cdot 100$ & \\
\hline
\end{tabular}


regarded as increasingly more applicable to the present study of New Albany Shale in the Illinois Basin as one moves from column 2 through to column 9. Columns 2 and 3 represent crustal abundances of the elements, whereas columns 8 and 9 represent the ranges of elemental concentrations for the correlative Chat tanooga and New Albany Shales outside Illinois. It might be expected that results of the current study will be most similar to the values in columns 8 and 9 .

\section{REFERENCES}

Clark, F. W., and H. S. Washington, 1924, The composition of the Earth's crust: U.S. Geological Survey Professional Paper 127, 117 p.

Gluskoter, H. J., R. K. Ruch, W. G. Miller, R. A. Cah111, G. B. Dreher, and J. K. Kuhn, 1977, Trace elements in coal: occurrence and distribution: Illinois State Geological Survey Circular 499. 154 p.

Kothandaraman, V., R. L. Evalls, N. G. Bliuwulk, J. B. BLall, D. L. Gros3, J. A. Lineback, and G. B. Dreher, 1977, Fox Chain of Lakes investigation and water quality management plan: Illinois State Water Survey and Illinois State Geological Survey Cooperative Resources Report 5, p. 23-24.

Krauskopf, K. B., 1955, Sedimentary deposits of rare metals: in Bateman, A. M., ed., Economic Geology, 50th Anniv. vol., 1905-1955: Urbana, IL, Economic Geology Publishing Co., p. 411-463.

Landis, E. R., 1962, Uranium and other trace elements in Devonian and Mississippian black shales in the central midcontinent area: U.S. Geological Survey Bulletin 1107-E, p. 289-336.

Leung, S. S., and T. F. Sanders, 1973, $\Lambda$ gcochcmical ctudy of the New Albany Shale in Kentucky: Ccological Society of America Abstracts with Prngrams for 1973, Southeastern Section, v. 5, no. 5, p. 413.

Peech, M., L. T. Alexander, L. A. Dean, and J. F. Reed, 1947, Methods of soil analysis for soil fertility investigation: USDA Circular 757.

Picard, M. D., W. D. Thompson, and C. R. Williamson, 1973, Petrology, geochemistry, and stratigraphy of black shale tacies of Gireen Kiver Formation (Eocene), Uinta Basin, Utah: Utah Geological and Mineral Sur-

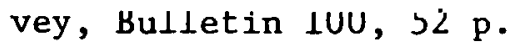

Ruch, R. R., H. J. Gluskoter, and N. F. Shimp, 1974, Occurrence and distribution of potentially volatile trace elements in coal: a final report: Illinois State Geological Survey Environmental Geology Note 72, 96 p.

Sh1mp, N. F., H. V. Leland, and W. A. While, 1970, Distribution of major, minor, and trace constituents in unconsolidated sediments from southern Lake Michigan: Illinois State Geologica1 Survey Environmental Geology Note 32, 19 p.

Taylor, S. R., 1964, Abundance of chemical elements in the continental crust: a new table: Geochimica et Cosmochimica Acta, v. 28, p. 1273-1285. 
Thomas, J., Jr., H. D. Glass, W. A. White, and R. M. Trandel, 1977, Fluoride contents of clay minerals and argillaceous earth materials: Clays and Clay Minerals, v. 25, p. 278-284.

Turekian, K. K., and K. H. Wedepoh1, 1961, Distribution of the elements in some major units of the Earth's crust: Geological Society of America Bulletin, v. 72, no. 2, p. 175-192.

Vine, J. D., and E. B. Tourtelot, 1970, Geochemistry of black shale depositsa summary report: Economic Geology, v. 65, no. 3, p. 253-272. 


\title{
IIC. Trace element distribution between shale inorganic and organic phases
}

\author{
J. K. Kuhn and R. A. Keogh
}

SCOPE AND PURPOSE

\begin{abstract}
Chemical and/or physical methods will be developed for the separation of the organic and inorganic phases of shales, and the trace elements that are associated with each phase will be determined. Methods tested will include float-sink gravity separations, mechanical separations (Humphrey Spiral), acid extractions, and zonal cetrifugation. Comparison of results of analyses for ten shales, their gravity fractions, and their separated organic phases will be made to determine the elements closely associated with organic matter. Separation procedures that seem most promising will be used to further study organically combined trace elements in additional shale samples. This research is designed to yield new information concerning chemical variations in shale organic matter, the shale component about which little is known and which may be the most characteristic feature of gas-bearing shales.
\end{abstract}

\section{RESULTS}

This project is scheduled to begin during the second year (Oct. 1 , 1977) of the contract, but preliminary work was undertaken on development of methods for the separation of organic matter (kerogen) from mineral matter in the shale. An organic product with approximately 1.5 percent ash has been prepared by acid-leaching of the shales with $\mathrm{HCl}, \mathrm{HNO}_{3}$, and $\mathrm{HF}$. The major component of the ash fraction appears to be titanium.

A density gradient generator will be acquired fur lle plujecl. IL is expected that with this device most of the remaining ash material can be freed from the organic matter of the shale. It the separation scheme proves successful, the chemical analyses of the organic portion from various shales will be made to determine whether concentration differences are related to gas-producing or to other shale characterlstics. 


\title{
IIIC. Mode of occurrence and relative distribution of hydrocarbon phases in shale
}

\author{
D. R. Dickerson and D. D. Coleman
}

SCOPE AND PURPOSE

This research is comprised of two related phases. The first involves determining the volume and composition of the off-gas for all cores collected for chemical analysis, and determining the relative distribution of hydrocarbons in ten specially prepared core samples, which are the same as those used in Task IIC. The samples will be preserved in airtight containers and subsequently analyzed for evolved gases, highly-volatile, low-molecularweight liquids, medium-volatile hydrocarbons, and solvent-extracted lowvolatile hydrocarbons using gas chromatography/mass spectrography (GC/MS) methods. Nonvolatile, high-molecular-weight hydrocarbons will be determined by GC analysis of shale pyrolytic products. Following completion of the gas analyses, the shales will be used for chemical analyses (Task IC) and gas adsorption studies (Task IVC).

The second phase involves determining whether or not isotopic analyses of off-gas from the canned samples provide meaningful information to help evaluate the gas-production capabilities of the black shales. This will be accomplished by isotopic analysis of methane from the canned samples available, by comparison of this information with other analytical data on the samples, and by experimental studies to determine the changes in chemical and isotopic composition that occur as gas is desorbed from a shale sample.

\section{ACCOMPLISHMENTS}

(1) The composition, relative hydrocarbon content, and volume of off-gas from two New Albany Shale cores-one from Christian County, Kentucky (01KY) and one from Effingham County, Illinois (02IL) were determined. Similar analyses were started on two other cores from Henderson and Tazewell Counties in Illinois.

(2) Isotopic analyses $\left(\mathrm{C}^{13} / \mathrm{C}^{12}\right.$ determinations) were performed on methane from four of the gas samples from the Christian County, Kentucky, core, and on methane from nine samples of the Effingham County, Illinois, core. These data were compared to the chemical analyses of the gas samples, and to vitrinite reflectance data where available.

(3) An experimental study was carried out in which an attempt was made to saturate a sample of the $01 \mathrm{KY}$ core with natural gas of known chemical and isotopic composition. This sample was then allowed to outgas while the composition of the gas released was monitored. 


\section{METHODS}

\section{Hydrocarbons}

For the analysis of off-gas from the New Albany Shale, samples have been collected at regular 10-ft intervals starting with the first sample at the 5-ft level below the coring point. The core samples are 3.5 or 4 in. in diameter and average about $4 \mathrm{in}$. in height. The samples are collected and sealed in metal containers as rapidly as is feasible after the core is brought to the surface.

The shale samples collected from the Christian County, Kentucky, core (01KY) were sealed in metal fruit-juice cans. The juice cans proved to be unsatisfactory in that they were difficult to monitor and at least three of thirteen cans developed leaks. Subsequent shale samples have been sealed in aluminum c.n nisters (fig. 31). l'he lid of this couldiner contuins a valve which is sealed with a rubber septum. The pressure within the container can be easily monitored using the device depicted in figure 32 or by use of a mercury manometer. Samples can be withdrawn with a syringe, or the accumulated gas can be bled off through the valve. There has been no apparent loss of gas due to leakage from the aluminum ca nisters. The head-space volume of the aluminum ca nisters is approximately three times that of the juice cans. This has the advantage of minimizing the error due to the pore volume of the shale when determining the volume of accumulated hydrocarbons.

The head-space gases are analyzed according to ASTM Standard Method for Natural Gas Analysis, Designation: D 1945-64. Samples (0.5 m1) of headspace gas were withdrawn with a gas-tight syringe and injected onto the gas chromatography column. The percentage of each component was determined by comparing relative peak height measurements of the shale off-gas to the peak height measurements of a standard natural gas sample.

\section{Isotopes}

Gas samples were taken by means of a hypodermic needle atlaclied to a sampl,ing-valve assembly similar to that described by Coleman (1976). This assembly consists of two small brass valves connected in series with a chamber of known volume between them. The claduber way evacuated and the hyporiermic needle then inserted into the septum on the sample ca nister. Opening the intake valve resulted in filling the chamber with the sumple gas. The sam pling assembly was then attached to the high-vacuum combustion system described by Coleman (1976). In this system, the merhane was purified and then converted to $\mathrm{CO}_{2}$ for isotopic analysis. The $\mathrm{C}^{13} / \mathrm{C}^{12}$ determinations were made on a Nuclide Model 6-60-RMS mass spectrometer at the Department of Geology, University of Illinois. All values are reported in per mil notation relative to the University of Chicago PDB standard:

$$
\begin{gathered}
\delta \mathrm{C}^{13}=\left[\frac{\mathrm{R}_{\text {sample }}}{\mathrm{R}_{\mathrm{PDB} \text { std. }}}-1\right] \times 1000, \\
\text { where R equals } \mathrm{C}^{13} / \mathrm{C}^{12} .
\end{gathered}
$$




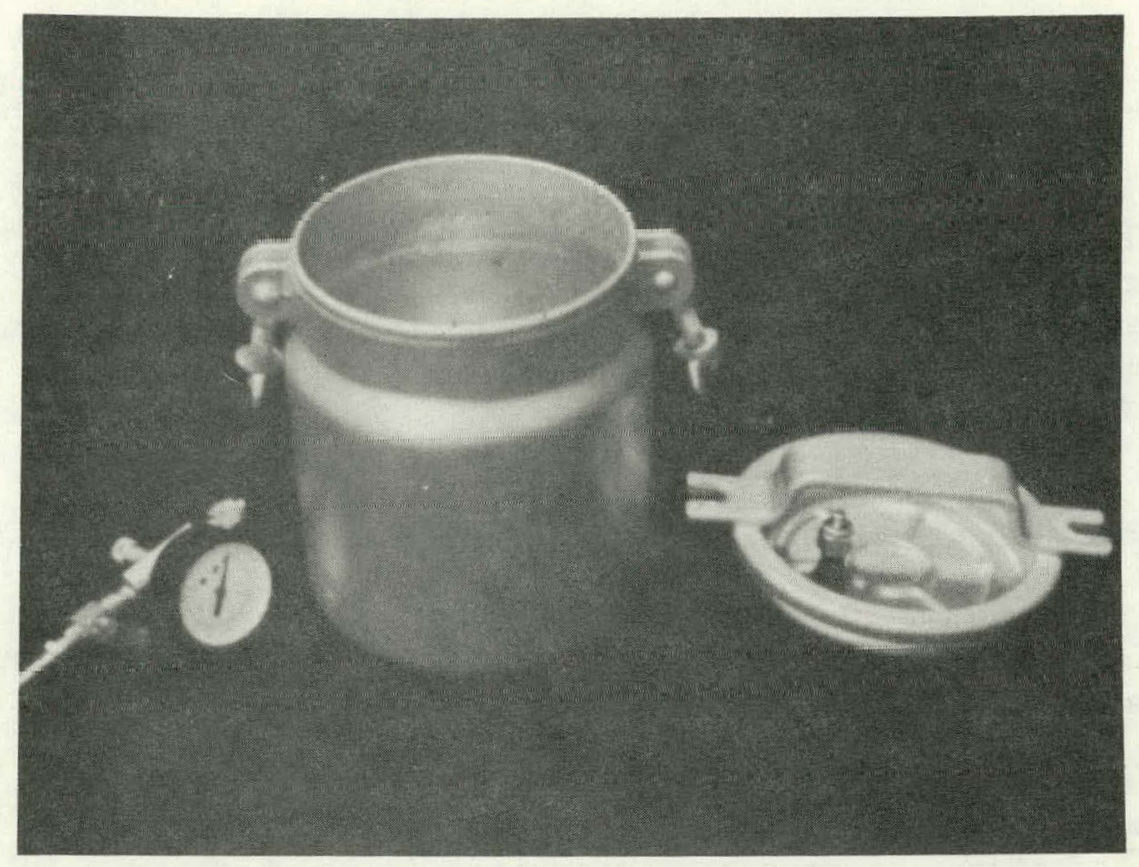

Fig. 31. Aluminum ca nister used for off-gas determinations.

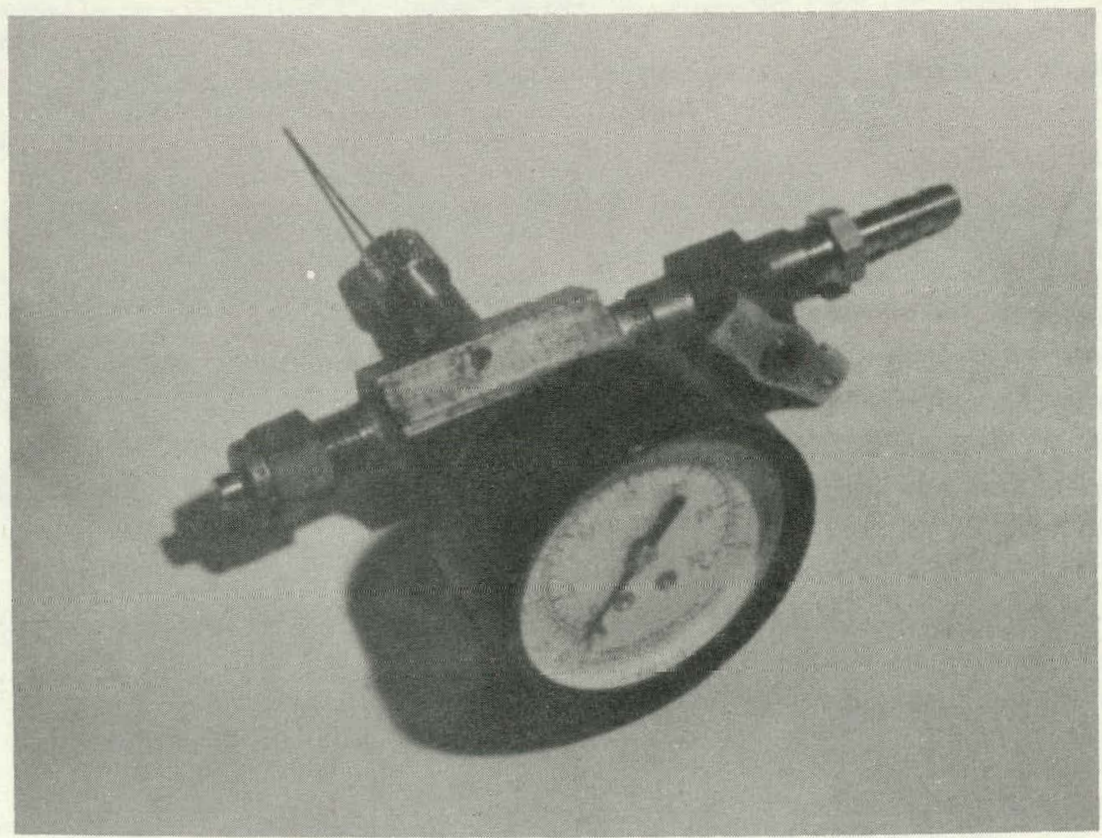

Fig. 32. Adapter used to monilor pressure in aluminum ca nisters and to collect gas samples. 


\title{
RESULTS AND DISCUSSION
}

\author{
Hydrocarbons
}

The composition of the head-space gas above the shale is given in tables 20 and 21 for the Christian County, Kentucky, and the Effingham County, Illinois, cores respectively. The relative hydrocarbon contents for these cores are given in tables 22 and 23, respectively (see also tables 24 and 25).

It should be noted that there is an apparent depletion of the oxygen content in the head-space gas compared to the original value in air (tables 20 and 21). It is not known at this time whether the depletion of oxygen is due to adsorption or to reaction (oxidation) or to both.

The volume of accumulated hydrocarbons, corrected to standard temperature and pressure conditions (STP) is calculuted from the measurements of the observed pressure, temperature, and head-space vulume. A positive correction is also made for the apparent volume (STP) of oxygen depletion. These values are given in tables 24 and 25. The Lime interval in days between collection of the sample and analysis is also given. The potential hydrocarbon resource is reported in standard cubic feet (SCF) of gas per cubic foot of shale. The values reported probably underestimate the actual hydrocarbon content of the in situ shale. Most of the sources of error-i.e., outgassing during the coring and canning process, can leakage, and the sorption of oxygen and possibly nitrogen by the shale during the equilibration period-would give values which are less than the true amount of hydrocarbon released.

A set of thirty samples has been collected from the Henderson County, Illinois, core (04IL) and another set of twenty-two samples has been collected from the 'lazewell County, Illinois (06IL). The pressure within the containers is being monitored weekly. The pressure values are decreasing, indicating an "ptake of oxygen that is more rapid than the release of hydrucirbons.

Tsntones

Christian County, KY, Core

Isotopic analyses were performed on methane from four of the gas samples from the Christian County, Kentucky, core (01KY) and the results are given in table 26. The $\delta \mathrm{C}^{13}$ values of samples $4 \mathrm{C} 1,7 \mathrm{C} 1$, and $11 \mathrm{Cl}$ are similar to those obtained on samples of gas from small gas wells in Illinois (Coleman, 1976). These values are typical of gas of low to moderate maturity, formed by thermal degradation of organic matter. Sumple $2 \mathrm{C} \perp$, however, is isulopically much heavier than the others (i.e., a larger $\mathrm{C}^{13} / \mathrm{C}^{12}$ ratio and a more positive $\delta c^{13}$ value), and the $\delta C^{13}$ value obtained is typical of relatively mature gas, such as that produced in the Gulf Coast region and the southcentral United States. This value appears to be anomalous when compared to the others from the same core.

Stahl (1974) has developed a model based on laboratory studies and analyses of gas samples from several areas of the world that relates the isotopic composition of methane to the hydrocarbon composition of the gas. According to the model, the first methane that is formed in a sedimentary 
TABLE 20-COMPOSंITION OF TOTAL HEADSPACE GAS, (01KY)

\begin{tabular}{|c|c|c|c|c|c|c|c|c|c|c|c|c|c|}
\hline \multirow[b]{2}{*}{ Conponents } & \multicolumn{13}{|c|}{ Mole percent } \\
\hline & $01 \mathrm{Cl}$ & $02 \mathrm{Cl}$ & $03 \mathrm{Cl}$ & $04 \mathrm{Cl}$ & $05 \mathrm{C} 1$ & $06 \mathrm{Cl}$ & $07 \mathrm{Cl}$ & $08 \mathrm{C} 1$ & $09 \mathrm{Cl}$ & $10 \mathrm{Cl}$ & $11 \mathrm{Cl}$ & $12 \mathrm{Cl}$ & $13 \mathrm{C} 1$ \\
\hline $\mathrm{O}_{2}$ & 6.21 & 6.12 & $9.8 \mathrm{t}$ & 17.21 & 3.22 & 15.84 & 2.25 & 9.21 & 6.29 & 14.00 & 5.05 & - & 8.47 \\
\hline $\mathrm{N}_{2}$ & 40.96 & 46.88 & 53.53 & 70.02 & 47.74 & 67.25 & 36.07 & 45.40 & 40.47 & 54.49 & 39.85 & - & 47.39 \\
\hline $\mathrm{CH}_{4}$ & 45.52 & 40.55 & 31.74 & 11.43 & 39.74 & 15.38 & 55.73 & 42.49 & 49.51 & 30.56 & 51.72 & - & 40.11 \\
\hline $\mathrm{CO}_{2}$ & 0.21 & 1.39 & $1.5<$ & 0.38 & 3.21 & 0.27 & 1.22 & 0.53 & 0.94 & 0.30 & 0.89 & - & 1.29 \\
\hline $\mathrm{C}_{2} \mathrm{H}_{6}$ & 5.56 & 3.92 & $2.3 i$ & 0.69 & 4.23 & 0.93 & 3.73 & 2.08 & 2.64 & 0.62 & 2.42 & - & 2.39 \\
\hline$\sigma_{3} H_{8}$ & 1.28 & 0.93 & 0.79 & 0.20 & 1.47 & 0.24 & 0.54 & 0.21 & 0.13 & 0.01 & 0.04 & - & 0.21 \\
\hline $\mathrm{i}-\mathrm{C}_{4} \mathrm{H}_{10}$ & 0.05 & 0.02 & 0.03 & 0.02 & 0.07 & 0.01 & 0.02 & 0.05 & 0.01 & 0.01 & 0.02 & - & 0.02 \\
\hline $\mathrm{n}-\mathrm{C}_{4} \mathrm{H}_{10}$ & 0.18 & 0.15 & 0.20 & 0.03 & 0.27 & 0.06 & 0.10 & 0.03 & 0.01 & 0.01 & 0.01 & - & 0.10 \\
\hline $\mathrm{i}-\mathrm{C}_{5} \mathrm{H}_{12}$ & 0.02 & 0.02 & 0.03 & 0.01 & 0.01 & 0.01 & 0.01 & $\mathrm{ND}^{*}$ & ND & ND & $\mathrm{ND}$ & - & 0.01 \\
\hline $\mathrm{n}-\mathrm{C}_{5} \mathrm{H}_{12}$ & 0.01 & 0.02 & 0.01 & 0.01 & 0.04 & 0.01 & 0.03 & ND & ND & $\mathrm{ND}$ & ND & - & 0.01 \\
\hline$>C_{6}$ & ND & ND & ND & ND & ND & ND & ND & ND & ND & $\mathrm{ND}$ & ND & - & $\mathrm{ND}$ \\
\hline
\end{tabular}

${ }^{*} \mathrm{ND}=$ none detected 
TAELE 21-CCMFOSITION OF TOTAL HEADSPACE GAS, (02IL))

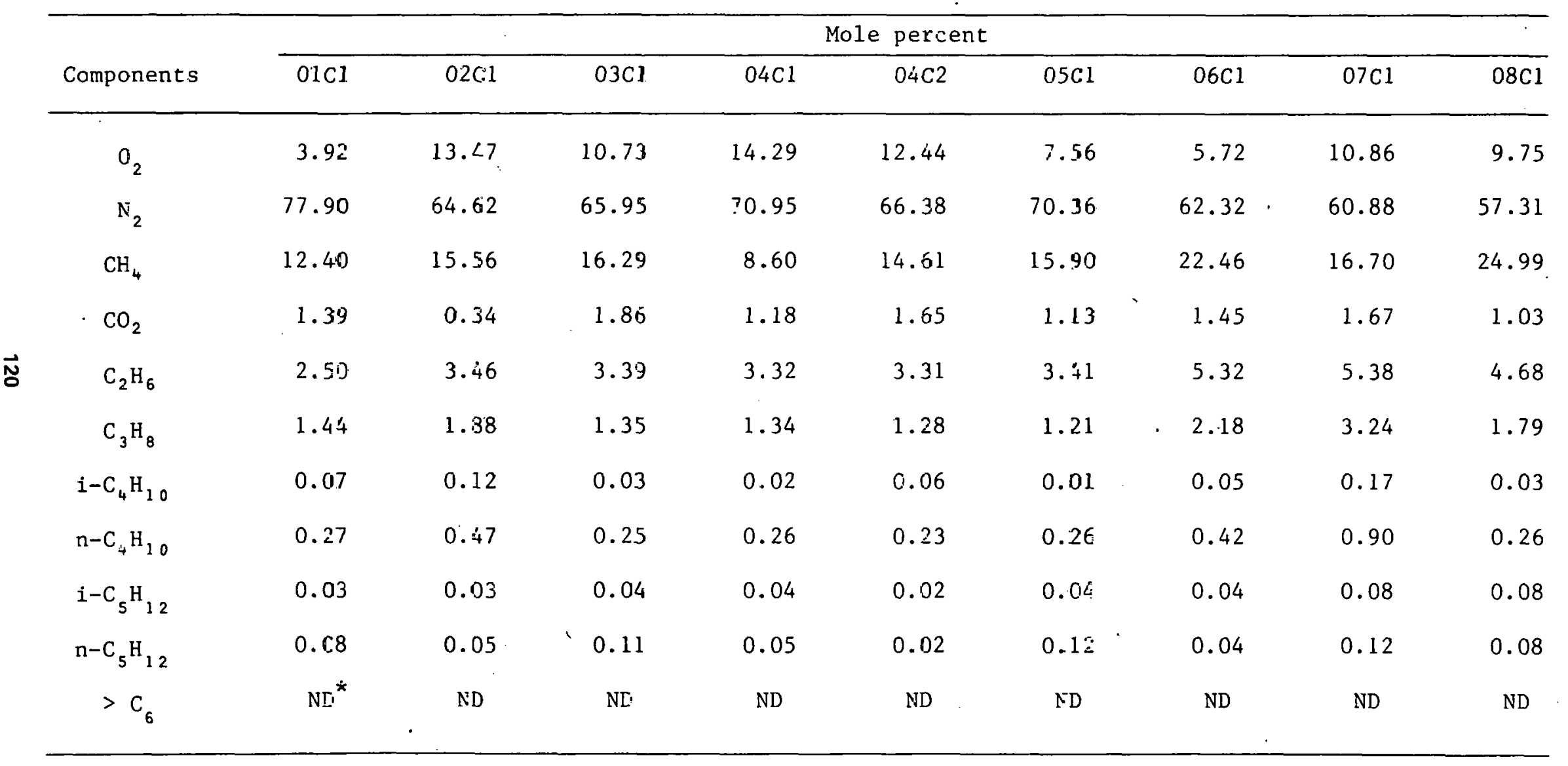

${ }^{*} \mathrm{ND}=$ none detected 
TABLE 22-COMPOSITION OF OFF-GAS, (01KY):

(weight percent hydrocarbon basis)

\begin{tabular}{|c|c|c|c|c|c|c|c|}
\hline $\begin{array}{l}\text { Sample } \\
\left.\text { (wt. } \text { w }^{\prime}\right)\end{array}$ & $01 C 1$ & $02 \mathrm{Cl}$ & $03 \mathrm{Cl}$ & $04 \mathrm{Cl}$ & $05 \mathrm{Cl}$ & $06 \mathrm{Cl}$ & 0701 \\
\hline $\begin{array}{c}\mathrm{CH}_{4} \\
\mathrm{C}_{2} \mathrm{H}_{6} \\
\mathrm{C}_{3} \mathrm{H}_{8} \\
1-\mathrm{C}_{4} \mathrm{H}_{10} \\
\mathrm{n}-\mathrm{C}_{4} \mathrm{H}_{10} \\
1-\mathrm{C}_{5} \mathrm{H}_{12} \\
\mathrm{n}-\mathrm{C}_{5} \mathrm{H}_{12} \\
>\mathrm{C}_{6}\end{array}$ & $\begin{array}{r}75.33 \\
17.25 \\
5.83 \\
0.29 \\
1.09 \\
0.14 \\
0.07 \\
\mathrm{ND}^{\star}\end{array}$ & $\begin{array}{c}79.15 \\
14.32 \\
4.99 \\
0.14 \\
1.06 \\
0.17 \\
0.17 \\
\text { ND }\end{array}$ & $\begin{array}{r}80.83 \\
11.05 \\
5.55 \\
0.26 \\
1.86 \\
0.34 \\
0.11 \\
\text { ND }\end{array}$ & $\begin{array}{c}84.63 \\
9.53 \\
3.90 \\
0.54 \\
0.76 \\
0.32 \\
0.32 \\
\text { ND }\end{array}$ & $\begin{array}{c}74.78 \\
14.91 \\
7.59 \\
0.47 \\
1.84 \\
0.08 \\
0.33 \\
\text { ND }\end{array}$ & $\begin{array}{r}84.84 \\
.9 .60 \\
3.63 \\
0.24 \\
1.21 \\
0.24 \\
0.24 \\
\text { ND }\end{array}$ & $\begin{array}{c}85.98 \\
10.78 \\
2.30 \\
0.11 \\
0.56 \\
0.07 \\
0.20 \\
\text { ND. }\end{array}$ \\
\hline $\begin{array}{l}\text { Sample } \\
\text { (wt. \%) }\end{array}$ & $08 \mathrm{Cl}$ & $09 \mathrm{Cl}$ & $10 \mathrm{Cl}$ & $11 \mathrm{Cl}$ & $12 \mathrm{Cl}^{\dagger}$ & $13 \mathrm{Cl}$ & \\
\hline $\begin{array}{c}\mathrm{CH}_{4} \\
\mathrm{C}_{2} \mathrm{H}_{6} \\
\mathrm{C}_{3} \mathrm{H}_{8} \\
\mathrm{i}-\mathrm{C}_{4} \mathrm{H}_{10} \\
\mathrm{n}-\mathrm{C}_{4} \mathrm{H}_{10} \\
\mathrm{I}-\mathrm{C}_{5} \mathrm{H}_{12} \\
\mathrm{n}-\mathrm{C}_{5} \mathrm{H}_{12} \\
>\mathrm{C}_{6}\end{array}$ & $\begin{array}{c}89.91 \\
8.26 \\
1.24 \\
0.37 \\
0.22 \\
\text { ND } \\
\text { ND } \\
\text { ND }\end{array}$ & $\begin{array}{c}90.20 \\
9.00 \\
0.64 \\
0.08 \\
0.08 \\
\text { ND } \\
\text { ND } \\
\text { ND }\end{array}$ & $\begin{array}{c}95.96 \\
3.67 \\
0.09 \\
0.14 \\
0.14 \\
\text { ND } \\
\text { ND } \\
\text { ND }\end{array}$ & $\begin{array}{c}91.56 \\
8.02 \\
0.21 \\
0.13 \\
0.08 \\
\text { ND } \\
\text { ND } \\
\text { ND }\end{array}$ & $\begin{array}{l}z \\
= \\
z \\
z \\
-\end{array}$ & $\begin{array}{c}87.78 \\
9.79 \\
1.28 \\
0.15 \\
0.80 \\
0.10 \\
0.10 \\
\text { ND }\end{array}$ & \\
\hline
\end{tabular}

${ }^{*}$ HD $=$ none detected

†No H-C detected; sample depleted 
TARLE 23-COMPOSITION OF OFF-GAS, (O2IL)

(weight percent hydrocarbon basis)

\begin{tabular}{|c|c|c|c|c|c|c|c|c|c|c|c|}
\hline $\begin{array}{l}\text { Sample } \\
\text { (wt. \%) }\end{array}$ & & $\mathrm{OlCl}$ & $02 \mathrm{Cl}$ & & $03 \mathrm{Cl}$ & $04 \mathrm{Cl}$ & $04 \mathrm{C} 2$ & $05 \mathrm{Cl}$ & $06 \mathrm{Cl}$ & $07 \mathrm{Cl}$ & $08 \mathrm{Cl}$ \\
\hline . $\mathrm{CH}_{4}$ & . & 45.29 & 45.72 & $\therefore$ & 57.26 & 56.24 & 57.13 & 59.44 & 55.04 & 43.08 & 61.70 \\
\hline $\mathrm{C}_{2} \mathrm{H}_{6}$ & $\cdots$ & 25.03 & 23.39 & & 2.73 & 23.19 & 23.43 & 22.71 & 23.43 & 23.04 & 21.21 \\
\hline $\mathrm{C}_{3} \mathrm{H}_{8}$ & & 19.59 & 19.50 & & 14.30 & 14.53 & 13.98 & 12.68 & 15.03 & 20.87 & 12.55 \\
\hline $\mathrm{i}-\mathrm{C}_{4} \mathrm{H}_{10}$ & & 1.67 & -.71 & & 0.51 & C. 62 & 0.55 & 0.42 & 0.71 & 1.60 & 0.57 \\
\hline $\mathrm{n}-\mathrm{C}_{4} \mathrm{H}_{10}$ & $\therefore$ & 6.13 & 5.92 & & 4.12. & 4.33 & 4.04 & 3.67 & 4.55 & 8.18 & 3.08 \\
\hline $\mathrm{i}-\mathrm{C}_{5} \mathrm{H}_{12}$ & & 1.09 & 1.29 & & 0.41 & 0.38 & 0.30 & 0.35 & 0.46 & 1.31 & 0.34 \\
\hline $\mathrm{n}-\mathrm{C}_{5} \mathrm{H}_{12}$. & . & 1.20 & 1.47 & & 0.67 & 0.71 & 0.57 & 0.73 & 0.78 & 1.92 & 0.55 \\
\hline$>\mathrm{C}_{6}$ & & Trace & $\mathrm{ND}^{*}$ & & ND & ND & ND & ND & ND & ND & ND \\
\hline
\end{tabular}

${ }^{*} \mathrm{ND}=$ none detected 
TABLE 24-CORE CHARACTERISTICS, (01KY)

\begin{tabular}{|c|c|c|c|c|c|c|c|c|c|c|}
\hline $\begin{array}{l}\text { Sample } \\
\text { number. }\end{array}$ & $\begin{array}{l}\text { Depth } \\
\text { to top } \\
(f t)\end{array}$ & $\begin{array}{l}\text { Welght } \\
\text { of shale } \\
\text { (g) }\end{array}$ & $\begin{array}{l}\text { Volume } \\
\text { of shale } \\
\left(\mathrm{cm}^{3}\right)\end{array}$ & $\begin{array}{l}\text { Bulk } \\
\text { density } \\
\left(\mathrm{g} / \mathrm{cm}^{3}\right)\end{array}$ & $\begin{array}{l}\text { Head- } \\
\text { space } \\
\left(\mathrm{cm}^{3}\right)\end{array}$ & $\begin{array}{c}\text { Time } \\
\text { Interval } \\
\text { (days) }\end{array}$ & $\begin{array}{l}\text { Observ. } \\
\text { press. } \\
\text { (psig) }\end{array}$ & $\begin{array}{l}\text { STP vol. } \\
0^{2} \\
\text { depleted } \\
\left(\mathrm{cm}^{3}\right)\end{array}$ & $\begin{array}{c}\text { STP } \\
\text { accumulated } \\
\text { hydrocarbon } \\
\left(\mathrm{cm}^{3}\right)\end{array}$ & $\begin{array}{l}\text { SCF gas/ } \\
\mathrm{ft}^{3} \text { shale }\end{array}$ \\
\hline $01 \mathrm{Cl}$ & 2182.3 & 1899 & 860 & 2.21 & 615 & $2^{\prime \prime}$ & 30 & 60 & 1268 & 1.47 \\
\hline $02 \mathrm{Cl}$ & 2191.2 & 1717 & $? 25$ & 2.37 & 775 & 54 & 7.5 & 87 & 467 & 0.64 \\
\hline $03 \mathrm{Cl}$ & 2220.3 & 1888 & $\because 755$ & 2.50 & 745 & 65 & 5.0 & 54 & 298 & 0.39 \\
\hline $04 \mathrm{Cl}$ & 2230.2 & 1564 & 592 & 2.64 & 908 & 71 & 3.5 & 24 & 232 & 0.39 \\
\hline $05 \mathrm{Cl}$ & 2240.1 & 1818 & 690 & 2.63 & 770 & 79 & 8.0 & 123 & 526 & 0.76 \\
\hline $06 \mathrm{Cl}$ & 2250.0 & 2407 & 890 & 2.70 & 610 & 72 & 1.5 & 21 & 81 & 0.09 \\
\hline $07 \mathrm{Cl}$ & 2260.2 & .1505 & 652 & 2.31 & 870 & 65 & 13.0 & 137 & 878 & 1.35 \\
\hline $08 \mathrm{Cl}$ & 2270.2 & 3848 & 1544 & 2.49 & 650 & 46 & 7.5 & 38 & 359 & .0 .23 \\
\hline $09 \mathrm{Cl}$ & 2280.5 & 2590 & $1025^{\circ}$ & 2.50 & 445 & 70 & 11.5 & 42 & 378 & 0.37 \\
\hline $10 \mathrm{Cl}$ & 2291.3 & 1870 & 759 & 2.38 & 361 & 52 & - & - & - & - \\
\hline $11 \mathrm{Cl}$ & 2299.7 & 2570 & 1042 & 2.47 & 458 & 46 & 10.0 & 53 & 353 & 0.34 \\
\hline $12 \mathrm{Cl}$ & 2404.5 & 1306 & 518 & 2.52 & 592 & $46^{\circ}$ & - & - & - & - \\
\hline 1301 & 2319.8 & 2644 & 1075 & 2.46 & 390 & - & - & - & - & - \\
\hline
\end{tabular}


TABLE 25-CORE CHARACTEEISTICS, (02IL)

\begin{tabular}{|c|c|c|c|c|c|c|c|c|c|c|}
\hline $\begin{array}{l}\text { Sample } \\
\text { number }\end{array}$ & $\begin{array}{l}\text { Depth } \\
\text { to top } \\
(f t)\end{array}$ & $\begin{array}{l}\text { Weight } \\
\text { of shale } \\
\text { (g) }\end{array}$ & $\begin{array}{l}\text { Volume } \\
\text { of shale } \\
\left(\mathrm{cm}^{3}\right)\end{array}$ & $\begin{array}{c}\text { Bulk } \\
\text { density } \\
\left(g / z m^{3}\right)\end{array}$ & $\begin{array}{l}\text { Head- } \\
\text { space } \\
\left(\mathrm{cm}^{3}\right)\end{array}$ & $\begin{array}{c}\text { Fime } \\
\text { interval } \\
\text { (days) }\end{array}$ & $\begin{array}{l}\text { Observ. } \\
\text { press. } \\
\text { (psig) }\end{array}$ & $\begin{array}{c}\text { STP vol. } \\
0 \\
\text { depleted } \\
\left(\mathrm{cm}^{3}\right)\end{array}$ & $\begin{array}{c}\text { STP } \\
\text { accumulated } \\
\text { hydrocarbon } \\
\left(\mathrm{cm}^{3}\right)\end{array}$ & $\begin{array}{l}\text { SCF gas/ } \\
\mathrm{ft}^{3} \text { shale }\end{array}$ \\
\hline $01 C 1$ & 3011.4 & 3063 & 1181 & 2.59 & 1609 & 98 & 2.0 & 307 & 359 & 0.30 \\
\hline $02 \mathrm{Cl}$ & 3021.4 & 2734 & 1065 & 2.57 & 1741 & 98 & 4.1 & 104 & 400 & 0.38 \\
\hline $03 \mathrm{Cl}$ & $30 \div 3.3$ & 2745 & 1118 & 2.46 & 1672 & 98 & 3.5 & 163 & 382 & 0.34 \\
\hline $04 \mathrm{Cl}$ & 3053.0 & 2677 & 1090 & $2.4 \epsilon$ & 1709 & 97 & 3.3 & 113 & 304 & 0.29 \\
\hline $04 \mathrm{C} 2$ & 30.59 .5 & 2251 & $9 \approx 0$ & 2.45 & 1884 & 97 & 3.1 & 138 & 336 & 0.37 \\
\hline $05 \mathrm{Cl}$ & 3065.3 & 2504 & 1031 & 2.43 & 1790 & 97 & 3.2 & 237 & 436 & 0.42 \\
\hline $06 \mathrm{Cl}$ & 3073.4 & 2833 & 1150 & 2.46 & 1651 & 97 & 4.3 & 317 & 620 & 0.54 \\
\hline $07 \mathrm{Cl}$ & $3 c .85 .5$ & 1982 & 775 & 2.56 & 2025 & 97 & 3.8 & 140 & 445 & 0.57 \\
\hline $08 \mathrm{Cl}$ & 3096.5 & 2834 & 1154 & 2.45 & 1657 & 97 & 5.5 & 149 & 583 & 0.51 \\
\hline
\end{tabular}


TABLE 26-CARBON-ISOTOPIC COMPOSITION OF METHANE FROM CORE O1KY*

\begin{tabular}{lc}
\hline Sample & $\delta C^{13} \% / 00$ \\
\hline $2 C 1$ & -41.7 \\
$4 C 1$ & -48.5 \\
$7 C 1$ & -49.1 \\
$11 C 1$ & -49.4 \\
\hline *Compositions are expressed \\
relative to the PDB standard. \\
The precision is $\pm .5 \%$ oo.
\end{tabular}

environment is the result of bacterial degradation of organic matter. The only hydrocarbon component formed is methane, and the'methane is isotopically very light $\left(\delta \mathrm{C}^{13}=-65\right.$ to $-90 \%$ oo). With deeper burial and increasing temperature, bacterial degradation of organic matter is replaced by thermal degradation. The first gas formed by this process is also primarily methane, but as the process continues and the temperature increases (i.e.", with increasing maturity), the proportion of heavier hydrocarbons (i.e., $\mathrm{C}_{2} \mathrm{H}_{6}, \mathrm{C}_{3} \mathrm{H}_{8}, \mathrm{C}_{4} \mathrm{H}_{10}$, etc.) formed increases. This continues unti.1 a point is reached where even the heavier hydrocarbon gases begin to break down to methane and the methane content of the gas again increases. Throughout the process the methane continually becomes isotopically heavier. This model is illustrated by the stippled region on figure 33.

The four points shown on figure 33 represent the samples from core 01KY. The four samples have compositions very close to those predicted by the model and suggest that the gas from sample $2 \mathrm{Cl}$ is more mature than that from the other samples.

To determine whether this trend is found throughout the core or only in these four samples, the hydrocarbon composition of 12 samples from the core were plotted as a function of depth (fig. 34). This plot shows that there is a general trend of increasing methane content with depth. Contrary to what one might expect, this implies that maturity increases from the bottom to the top of the core. In fact, because the interval studied is only about $100 \mathrm{ft}$ thick, one would expect little if any difference in maturity between the samples.

The vitrinite reflectance data, presented in section IIG of this report (see table 9), is an indication of the maturity of the solid organic material in the sediments. These data suggest that the organic material is relatively immature and that the maturity is fairly constant throughout the section of the core studied. These data support the previous implication that the isotopic and chemical data suggest an anomalous situation.

Stah1 (1977) and Stahl and Carey (1975) have found a direct relationship between the vitrinite reflectance of organic matter and the isotopic composition of the associated methane. The stippled region on figure 35 shows 


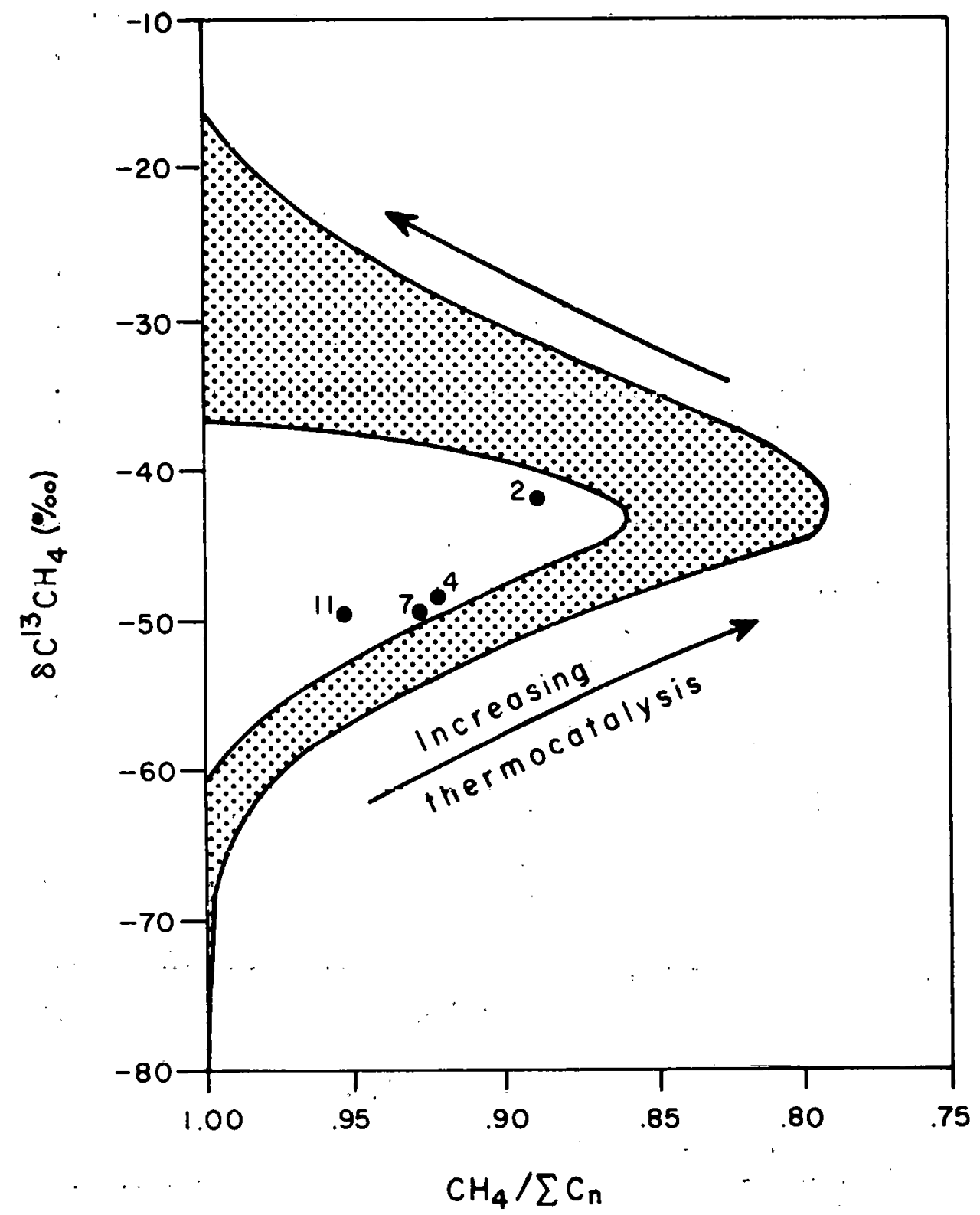

Fig. 33. Maturity plot for gas samples from core 01KY. (After Stah1, 1974.) Hydrocarbon compositions are in mole fraction. 


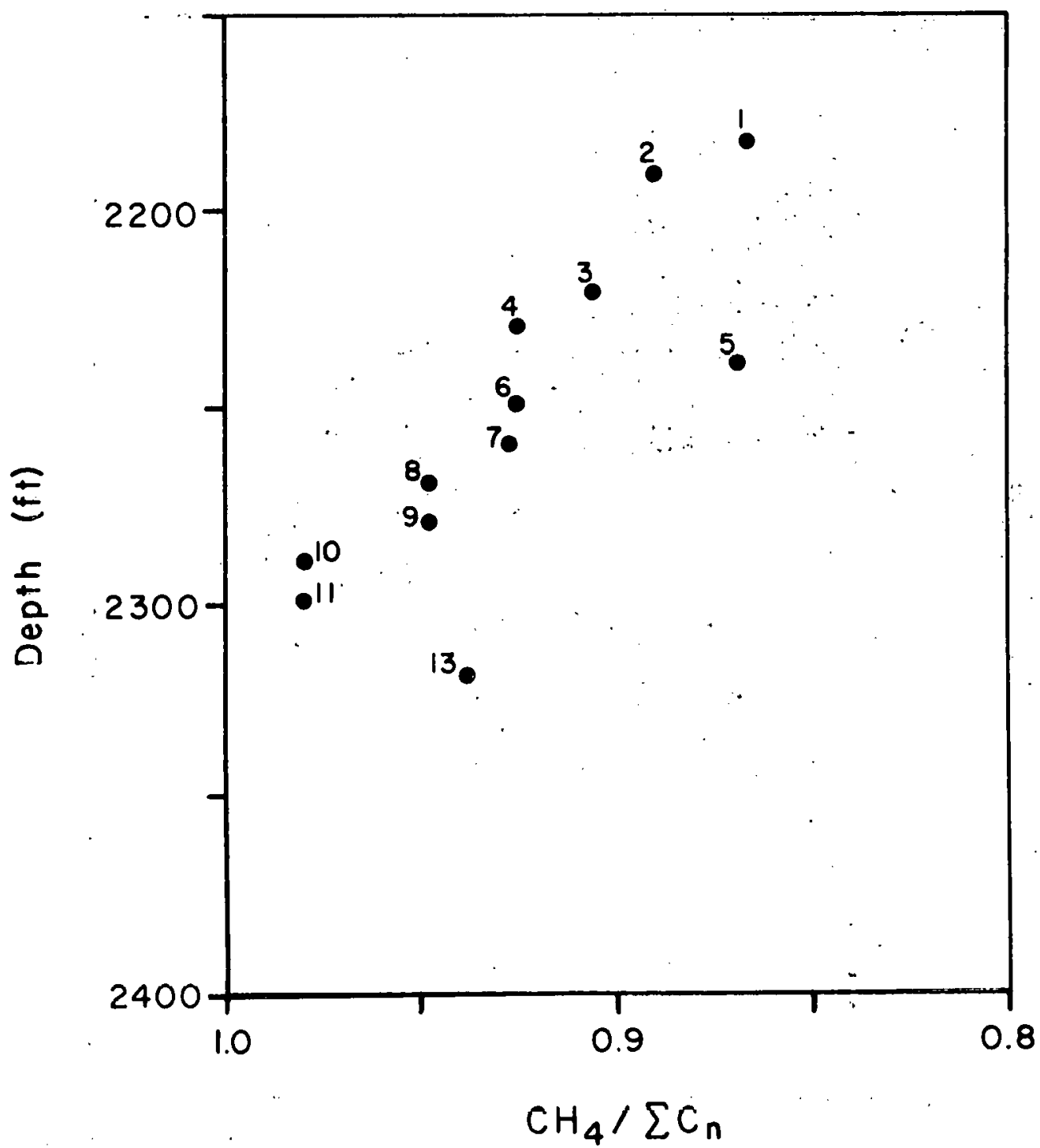

Fig. 34. Hydrocarbon composition as a function of depth for gas samples from core $01 \mathrm{KY}$. 


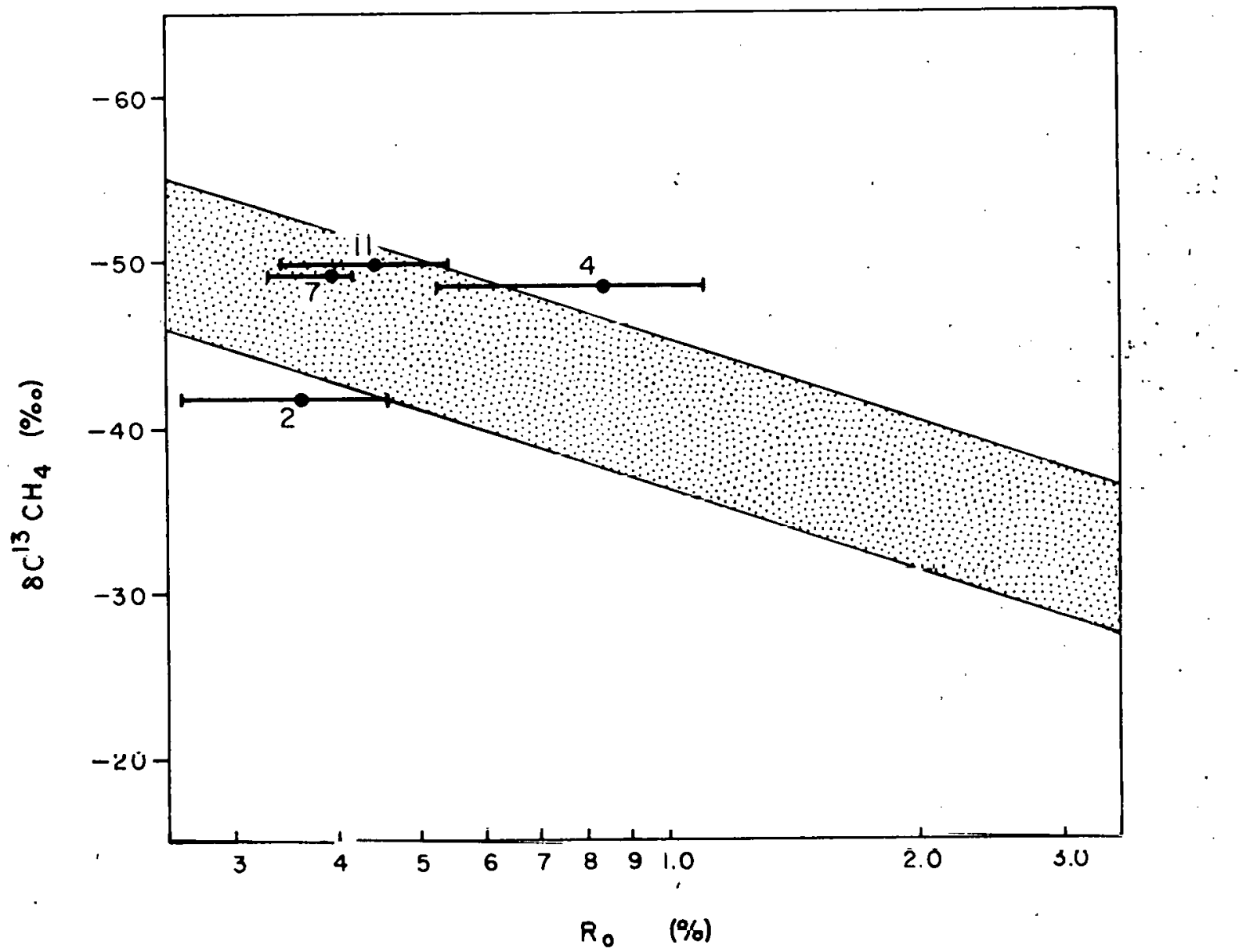

Fig. 35. Comparison of the isotopic composition of methane to the vitriuite reflectance of the aesociated shale. 
the range of compositions observed by Stahl (1977) for natural gas formed from sapropelic source material. Increasing maturity would result in a progression from left to right. It can be seen that samples $7 \mathrm{C} 1$ and $11 \mathrm{Cl}$ have compositions within the expected range, but that sample $4 \mathrm{Cl}$ appears to have an $R_{0}$ value that is unexpectedly high. However, figure 22 suggests that this value may be a statistical deviant and that the true value may be very close to that of samples $7 \mathrm{Cl}$ and $11 \mathrm{Cl}$. Therefore on figure 35 as well as on figure 33 , sample $2 C 1$ appears to have a $\delta C^{13}$ value that is less negative than expected. There are at least two possible explanations for this observation.

In taking the section of core from which sample $2 \mathrm{Cl}$ was obtained, a great deal of difficulty was encountered in removing the core from the hole. Therefore, the time that elapsed between cutting the core and canning the sample was much greater for sample $2 \mathrm{Cl}$ than for the ọther samples. As a result, a greater quantity of gas could have been lost from this sample before canning than for the other samples. If this loss of gas was accompanied by chemical and isotopic fractionation, the remaining gas would be depleted in $C^{12}$ (i:e., it would have a less negative $\delta C^{13}$ value) and in $\mathrm{CH}_{4}$ (a lower $\mathrm{CH}_{4} /$ $C_{n}$ value). Although both of these conditions do exist, figure 34 shows that the depletion in $\mathrm{CH}_{4}$ in sample $2 \mathrm{Cl}$ is in line with that observed for the other samples. This depletion does not therefore appear to be strongly related to the difference in time that elapsed between coring and canning for the various samples.

Another possible explanation is that, in the area where this core was taken, gas has migrated out of the shale into the overlying strata. When gases flow through porous materials via diffusional processes, the different components may migrate at different rates. In most cases, the lighter components migrate more rapidly. If gas has been migrating out of the shale very slowly, over a long period of time, the remaining gas is likely to be enriched in the heavier components (i.e., $\mathrm{C}^{13} \mathrm{H}_{4}$ relative to $\mathrm{C}^{12} \mathrm{H}_{4}, \mathrm{C}_{2} \mathrm{H}_{6}$ relative to $\mathrm{CH}_{4}$, etc.). Also, if the migration were upward, the upper portion of the shale would be more affected than the lower portion.

This hypothesis appears to best fit the data; however, a comparison of this data to that from other cores will be necessary before a final conclusion can be drawn.

\section{Effingham County core}

Isotopic determinations have been made on methane from all nine of the gas samples collected from the Effingham County, Illinois, core (02IL); these results are given in table 27 . There is little variation among the samples, and no trends are apparent. The isotopic data suggest that this gas is also relatively immature (even more so than that from the previous core) and that the maturity is fafrly constant throughout the core.

Figure 36 shows the relationship between the isotopic and hydrocarbon compositions of the samples. The hydrocarbon compositions suggest a much greater maturity than that implied by the isotopic data. These samples have hydrocarbon compositions that are considerably different from any of the samples that Stahl used to develop his model, and also fium any samples that have been collected from gas wells in tllinois. 


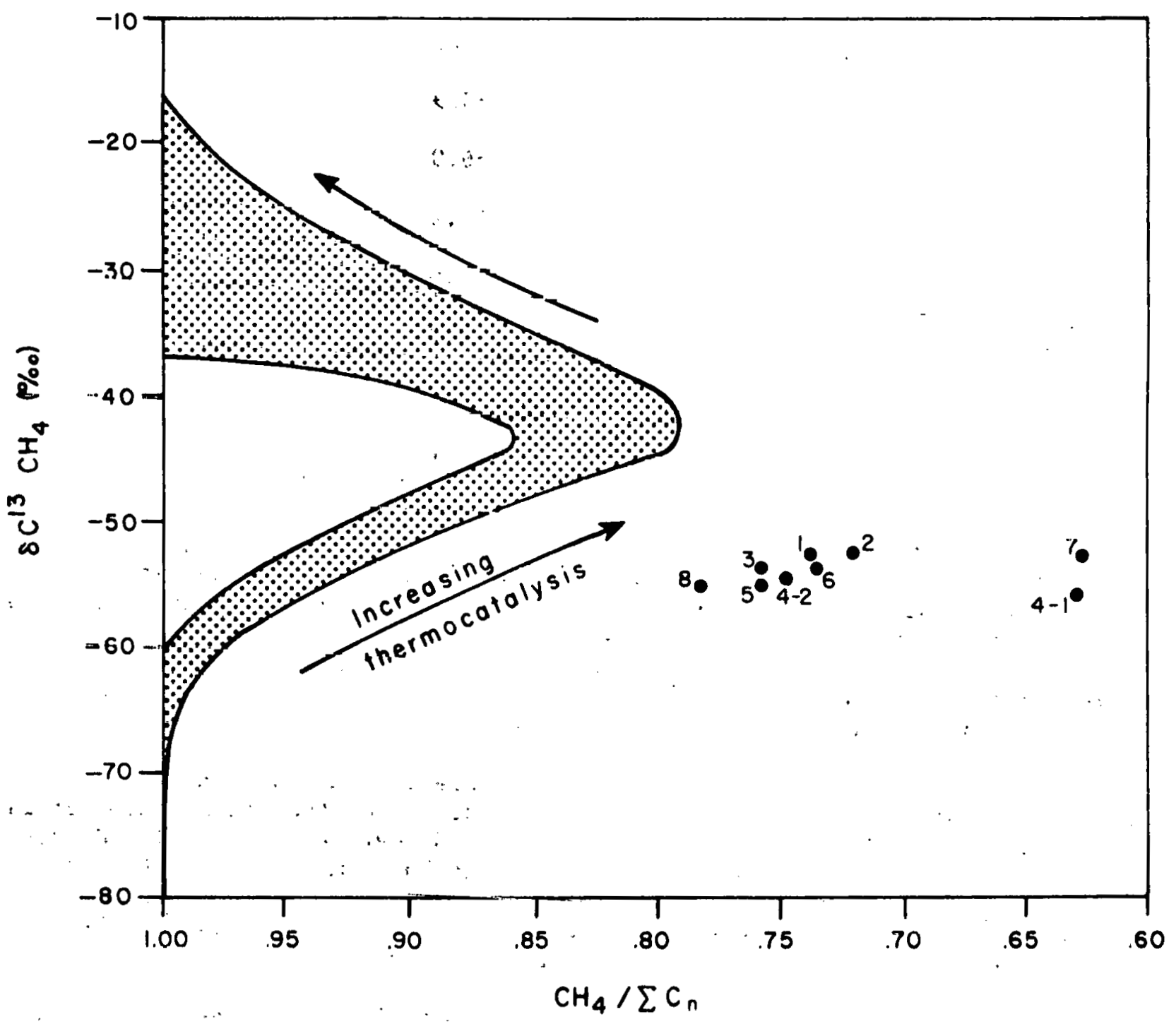

Fig. 36. Maturity plot for gas eamples from core 02IL, 
TABLE 27-CARBON-ISOTOPIC COMPOSITION OF METHANE FROM CORE O2IL

\begin{tabular}{cc}
\hline Sample & $\delta \mathrm{C}^{130 / 00}$ \\
\hline $01 \mathrm{Cl} 1$ & -52.8 \\
$02 \mathrm{Cl}$ & -52.3 \\
$03 \mathrm{Cl} 1$ & -53.9 \\
$04 \mathrm{C} 1$ & -56.0 \\
$04 \mathrm{C} 2$ & -54.2 \\
$05 \mathrm{C} 1$ & -54.8 \\
$06 \mathrm{C} 1$ & -53.7 \\
$07 \mathrm{C} 1$ & -53.1 \\
$08 \mathrm{C} 1$ & -55.0 \\
\hline
\end{tabular}

The hypothesis of diffusional migration of gas out of the shale proposed to explain the results from the previous core does not appear to apply to this core. Because diffusional processes are primarily mass dependent, one would therefore expect to see a change in the isotopic composition correlative with the change in the hydrocarbon composition. No change, however, appears to be present in these samples. When available, the vitrinite reflectance data may also shed some light on this problem.

The unit directly below the black shale produces ofl that is saturated with gas; samples of this gas were collected from the gas-oil separators on two oil wells. The isotopic composition of the methane was nearly identical to that from the shale samples. The hydrocarbon composition of the gas was also very similar to that from the shale, although compositions from the oil wells had a slightly higher $\mathrm{CH}_{4}$ content. It thus appears likely that the gas in this shale has migrated from the underlying units.

The chemical composition of this gas may also have been affected by the sampling process. A considerable amount of time elapsed between the time when the shale was cored and when $1 t$ was actually sealed in containers. During this time, a large portion of the contained gas may have escaped from the shale. In this type of rapid migrational situation, adsorptivity and molecular size would be expected to be the most significant characteristics affecting the relative rates of loss of the various components. Because

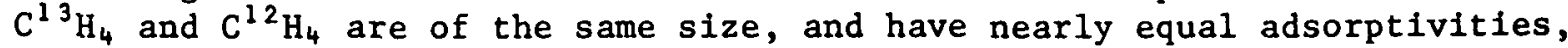
little effect on the isotopic composition of the gas would be expected. A large change in the hydrocarbon composition of the gas could be possible, however, with the residual gas becoming enriched with heavier components. 


\section{LABORATORY STUDY OF GAS FRACTIONATION}

A laboratory study is being conducted to help evaluate the changes in isotopic and/or chemical composition occurring as a result of the loss of gas that may take place during the collection of core samples. An attempt is being made to duplicate conditions that exist during collection of samples.

A segment from core $01 \mathrm{KY}$ was sealed in a high pressure vessel and evacuated for 96 days to remove virtually all of the gas originally present. The vessel was then filled to a pressure of 965 psi with natural gas of known chemical and isotopic composition. After 76 days, uptake of gas appeared to have stopped, and it was assumed that equilibrium had been achieved. The gas was then gradually released over a period of $2 \mathrm{hr}$, simulating the gradual decrease in pressure that occurs as a core sample ie removed from a well. The pressure was then maintained at atmospheric pressure for another $2 \mathrm{hr}$, simulating the time during which a core is described and segmented for canning.

Splits of the gas released were collected at periodic intervals and analyzed. The results of these analyses are shown on figure 37 . The figure shows that the first.gas released had a chemlcal composition very close to that of the gas originally injected, with perhaps a very sllglit enichment of methane relative to the heavier hydrocarbons. However, the gas released later was depleted in $\mathrm{CH}_{4}$ and enriched in the heavier components.

The isotopic composition appears to show a reverse trend, with the initial gas depleted in $C^{12}$ and the later gas enriched in $C^{12}$. This is contrary to what was expected, because $\mathrm{C}^{12} \mathrm{H}_{4}$ should diffuse out of the shale more rapidly than $\mathrm{C}^{13} \mathrm{H}_{4}$, causing the residual gas to become enriched in $\mathrm{C}^{13} \mathrm{H}_{4}$. These data imply that the injected gas had not completely equilibrated with the shale sample. If only partlal equilibration had occurrod, the gas that had migrated farthest. into the sample would be enriched in $\mathrm{C}^{12} \mathrm{H}_{4}$ and that nearest the surface of the sample would be depleted in $\mathrm{C}^{12} \mathrm{H}_{4}$ relative to $\mathrm{C}^{13} \mathrm{H}_{4}$. Upon release of the gas, the first gas to come off would be that nearest the surface and would therefore be enriched in $\mathrm{C}^{1{ }^{3}} \mathrm{H}_{4}$, as was ubserved in the experlment.

After the initial $4 \mathrm{hr}$ of gas release, the sample was closed in and the pressure allowed to build up, simulating the canning of a core sample. Gas samples were again collected at periodic intervals and andyzed. Figure 38 shows the compositions of these samples along with (for comparison) the first and last samples collected during the initial release of gas. For the first few days, the trends were the same as those observed in the first few hours. However, the later data appear to indicate reverse trends. This again suggests that the sample had not equilibrated with the gas infecled.

Gas is still being released by the shale, and periodic samples are still being collected and analyzed. A complete treatment of the data and evaluation of the experiment will not be possible until all the gas has been removed from the shale and mass balance calculations have been made. The data do indicate, however, that significant cherical and isotopic fractionation occurs upon rclease of gas from a shale sample. 


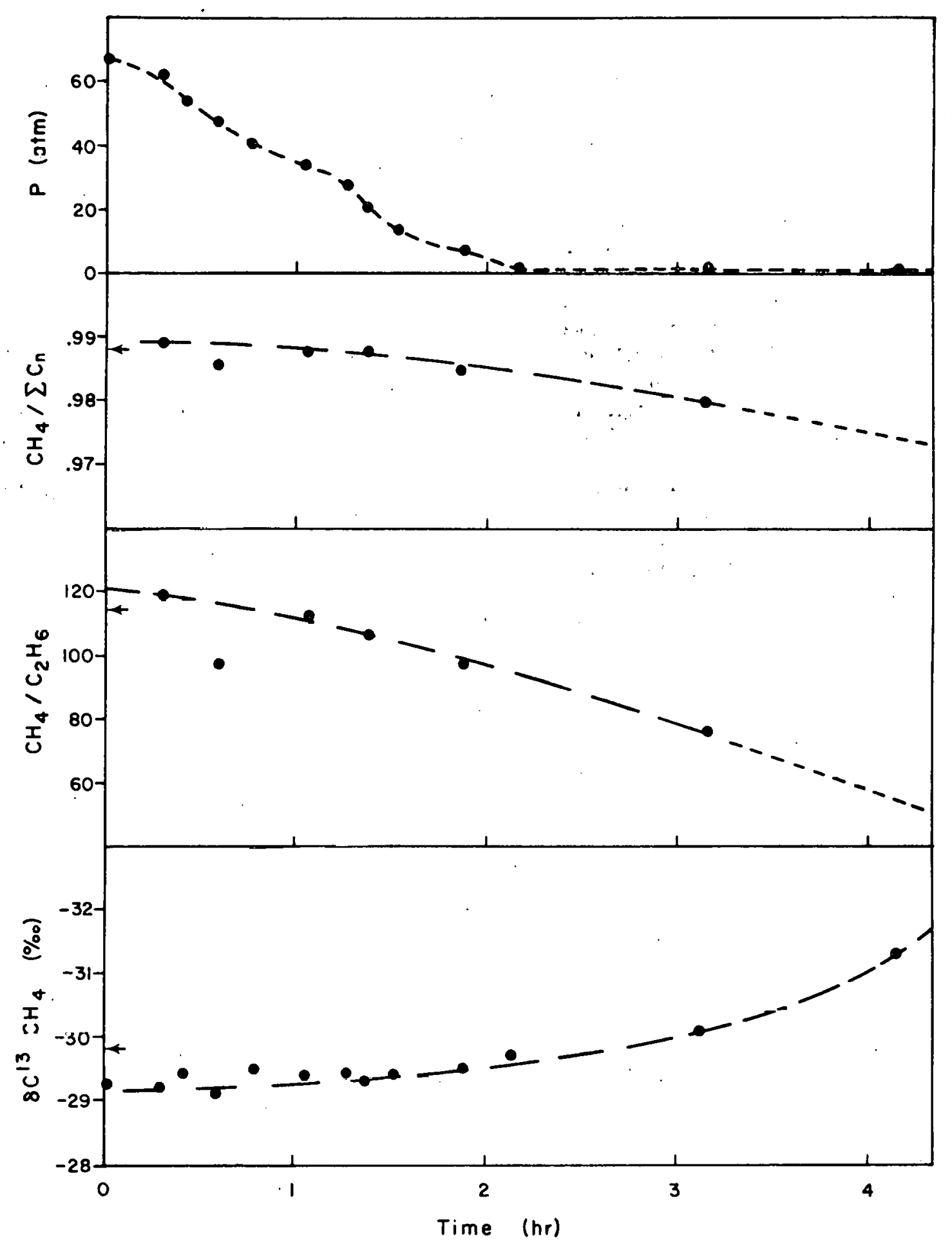

Fig. 37. Changes in the composition of the off-gas during the first $4 \mathrm{hr}$ of outgassing. Arrows indicate composition of injected gas. 


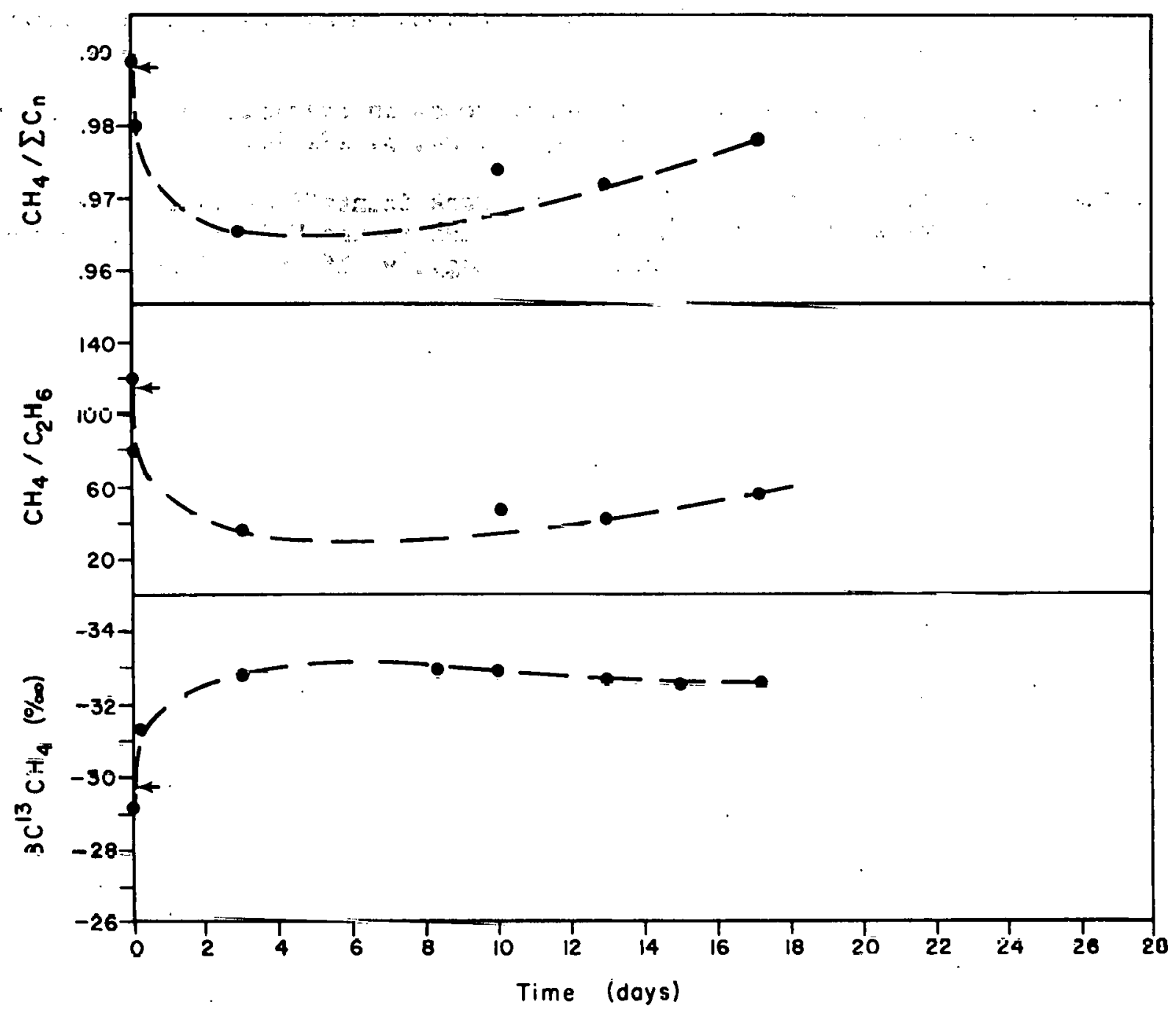

Fig. 38. Composition of the off-gas during the final stage of the degassification experiment. Arrows indicate the composition of the gas originally injected. 


\section{REFERENCES}

Coleman, D. D., 1976, Isotoplc characterization of Illinois natural gas: Ph.D. Dissertation, University of Illinols, $175 \mathrm{p}$.

Stahl, W...J., 1974, Carbon isotope fractionations in natural gases: Nature, v. 251 , p. 134-135.

Stah1, W. J., 1977, Carbon and nitrogen isotopes in hydrocarbon research and exploration: Chemical Geology, v. 20, p. 121-149.

Stah1, W. J., and B. D. Carey, 1975," Source-rock Identification by 1sotope analyses of natural gases from flelds in the Val Verde and Delaware basins, west Texas: Chemical Geology, v. 16, p. 257-267. 


\title{
IVC. Adsorption/desorption studies of gases through shales
}

\author{
Josephus Thomas, Jr., and Robert R. Frost
}

SCOPE AND PURPOSE

Internal surface areas will be determined with nitrogen and carbon dioxide on 900 shale core samples; on 100 of these, methane will also be used as the adsorbate. Methane adsorption (sorption) isotherms for these 100 Ehales wil1 be determined at pressures within the range of 1 to 80 atmospheres. Comparison of these properties in gas-producling aul non gac-produring shales will be made to determine the relationship of shale physical properties to gas recovery.

Sorption studies by Breck et al. (1956) and Lamond (1962) on wulecular sieves, and by Walker and Geller (1956) and Anderson et al. (1956, 1965) on coals, have shown that nitrogen (at $-196^{\circ} \mathrm{C}$ ) is unable to penetrate pores having diameters less than about 4.5 to 5 angstroms ( $($ ), whereas carbon dioxide $\left(\right.$ at $-77^{\circ} \mathrm{C}$ ) is able to do so. Thus, $\mathrm{CO}_{2}$ at $-77^{\circ} \mathrm{C}$ is a valuable molecular probe in evaluating the presence of ultramicropores in an interconnecting, or partially-interconnecting, open-pore structure. A measure of the ultramicroporosity present in a sample is the internal surface area (ISA). estimated from the Brunauer, Emmett, and Teller (BET) method (1938). No other experimental approach is quite as sallsfictory.

The presence of such ultramicroporosity in sliales is elgnifirant in that hydrnsarbons (with little side branching) can occupy the ultramicropores, and their diffusion rates from such pores will be signifleainty lowar than diffusion rates frum ldiger porc etructures. Thus, measurements with nitrogen and carbon dioxide provide a "handle" to the tightness or compactness of the shale structure.

High-pressure methane adsorption (sorption) isotherms provide supplemental information segarding the total porosity (encompassing macropores as well as ultramicropores) and regarding the possible gas-holding capacitles of shale samples at their depths of burfal. The nitrogen and carbon dioxide data are inadequate for these purposes.

\section{ACCOMPLISHMENTS}

(1) Fifty internal surface area measurements were completed (milestone 14).

(2) Pressure apparatus for methane sorption were constructed (milestone 12). Slight modifications are now being made to improve the temperature control.

(3) Six methane-adsorption isotherms were completed. The task milestone (15) called for completion of 10 methane adsorption 1sotherms. When modifications of apparatus are completed, this work will progress rapidly. 


\section{METHODS}

Data for internal surface area (ISA) measurements with $\mathrm{N}_{2}$ and $\mathrm{CO}_{2}$ as adsorbates at $-196^{\circ} \mathrm{C}$ and $-77^{\circ} \mathrm{C}$, respectively, were obtained by a dynamic sorption method. This method is commonly called the gas chromatographic method, as the principles involved in the measurements are similar to those used in gas chromatography. The apparatus is basically that first described by Nelson and Eggertsen (1958) and later defined by Daeschner and Stross (1962).

For the determination of high-pressure ( 1 to 80 atmospheres) methane sorption isotherms, an apparatus similar to that described by Dubinin et al. (1958) was constructed with slight modifications for improved readout of pressures.

Shale samples were crushed and screened. The 40-x-120-mesh (about 425 to. $.125 . \mu \mathrm{m}$ ) sieve fractions were used for the internal surface area measurements with $\mathrm{N}_{2}$ and $\mathrm{CO}_{2}$ as adsorbates. The $6-\mathrm{x}-12$-mesh (about 2.4 to $1.7 \mathrm{~mm}$ ): sieve fractions were used for the high-pressure methane sorption isotherms.

For the ISA determinations, shale samples of 0.5 to $1.0 \mathrm{~g}$ were outgassed at $110^{\circ} \mathrm{C}$ in a stream of helium for $3 \mathrm{hr}$. Three-point BET plots were used with $\mathrm{N}_{2}$ as the adsorbate at $-196^{\circ} \mathrm{C}$. A check on two different samples showed that no additional $\mathrm{N}_{2}$ beyond that adsorbed in the first 10 min was adsorbed after $4 \mathrm{hr}$ at a constant relative pressure. Thus, an equilibrium time of 10 min was suitable for each point. With $\mathrm{CO}_{2}$ as the adsorbate at $-77^{\circ} \mathrm{C}$, however, an equilibrium time of $16 \mathrm{hr}$ was used, because of the slow activated diffusion. A single point BET plot passing through the origin was used as a measure of the ISA. A relative pressure $\left(P / P_{0}\right)$ of about 0.15 was used for $\mathrm{CO}_{2}$; the saturation vapor pressure was $1450 \mathrm{~mm}$. The area occupied by the $\mathrm{CO}_{2}$ molecule under the experimental conditions employed was $22.1 \AA^{2}$, based on calibration with standards of known surface areas.

For the high-pressure methane sorption isotherms, approximately 50$60 \mathrm{~g}$ of sample were weighed into a high-pressure cell, and outgassing was conducted under vacuum near $100^{\circ} \mathrm{C}$ until a pressure of less than $10^{-3} \mathrm{~mm}$ was attained. The dead space was determined with helium. Known increments of methane were transferred to the system, and pressure differences were determined at constant temperature as a measure of the uptake of methane by the sample.

Samples from three cores from the Illinois Basin have been studiedone core (OlKY) from Christian County, Kentucky, an older core (01IL) from Sangamon County, Illinois, and a recent core from Effingham County, Illinois (02IL).

\section{RESULTS AND DISCUSSION}

Internal surface area values are given in tables 28,29 , and 30 for samples from the three cores. Since the external surface area of 40-x-120-mesh porous particles is an insignificant fraction (less than $0.1 \mathrm{~m}^{2} / \mathrm{g}$ ) of the total measured surface, it is included in each of the ISA values. 
A surface area value for a shale sample, either from $\mathrm{CO}_{2}$ or $\mathrm{N}_{2}$ adsorption data, will be governed to some extent by the mineral heterogeneity of the sample (i.e., the presence of silica, carbonates, and other inorganic components, and variations in the clay minerals ratio) and by the crystallite sizes of the components. Accordingly, until chemical and mineralogical analyses are completed for correlative purposes, the significance of individual variations in ISA within either the third or fourth columns of tables 28, 29, and 30 is questionable.

Since the compositional variations between samples are "seen" equally well by either $\mathrm{N}_{2}$ or $\mathrm{CO}_{2}$ as the sorbate gases, of more significance than absolute values are the $\mathrm{CO}_{2} / \mathrm{N}_{2}$ ISA ratios shown in the fifth column of each table. The larger this ratio, the greater the proportion of the porosity that is contained in pores less than 4.5 to $5 \&$ in diameter. Carbon dioxide at $-77^{\circ} \mathrm{C}$ penetrates these pores whereas $\mathrm{N}_{2}$ at $-196^{\circ} \mathrm{C}$ does not, thereby producing a larger ISA value trom $\mathrm{CO}_{2}$ sorption compared with that from No sorption. When the ratio is large, the sample has a more compact pore structure, and the diffusion rates of contained gases will be lower than those from samples having smaller ISA ratios. With the latter samples, it is readily ascertained from the data that $\mathrm{N}_{2}$ at $-196^{\circ} \mathrm{C}$ reaches a greater proportion of the internal surface. In those cases where the ISA ratio is essentially $1, \mathrm{~N}_{2}$ reaches the same surface as that reached with $\mathrm{CO}_{2}$, indicating that there is 11ttle porosity associated with pores less than 4.5 to $5 \AA$ in diameter in these samples.

The ISA ratios for the shale samples from the Kentucky core (table 28) are appreciably larger, in general, than the ISA ratios for samples from the Sangamon County, Illinois, core (table 29). ISA values for samples from the Effingham County, Illinois, core (table 30) are intermediate.

Although the organic carbun contentc of samples from the latter core were incomplete at this writing, the organic carbon contents of samples from the Kentucky core (table 28) are, in general, greater than Lhuse for samples from the Sangamon County, Illinois, core (table 29). In fact, the ISA ratios show a highly significant positive correlation with the organic carbon contents. Figure 39 ls a plot of this relatinnship for samples from the Kentucky core, and figure 40 is a similar plut for samples from the Sangamon County, Illinois, core. The correlation in figure 10 is not as good as that shown in figure 39, owing possibly to the age of samples from the Sangamon County, Illinois, core (taken in 1939). The oxidation of organic watter after removal of the protective (rejduclng almosphere) organic gases through diffusion could bring about the noted decrease in correlation.

I.t. is probable that much of the nongaseous (as well as gaseous) organic matter occupies and lines pores which are inherently present in shales, effectively reducing pore diameters to the extent that $\mathrm{N}_{2}$ can no longer permeate the porosity, but $\mathrm{CO}_{2}$ can. As a further check on this concept, sample $01 \mathrm{Cl}$ from the Kentucky core, which had the largest $\mathrm{CO}_{2} / \mathrm{N}_{2}$ ISA ratio (26.2), was selected for outgassing at higher temperatures to study the influence of this treatment on the ISA values. These data are summarized in table 31 .

Although the ISA from $\mathrm{CO}_{2}$ sorption does not change markedly after outgassing at $230^{\circ} \mathrm{C}$ and $340^{\circ} \mathrm{C}$, the ISA from $\mathrm{N}_{2}$ sorption increases about fourfold after outgassing at $340^{\circ} \mathrm{C}$. The weight loss also increases sharply. As this outgassing temperature is not sufficiently high to cause a breakdown of 
TABLE 28-INTERNAL SURFACE AREA VALUES FOR SHALE SAMPLES FROM CORE OIKY

\begin{tabular}{|c|c|c|c|c|c|}
\hline \multirow[b]{2}{*}{ Sample number } & \multirow{2}{*}{$\begin{array}{l}\text { Depth to } \\
\text { top of } \\
\text { sample } \\
\text { (ft) }\end{array}$} & \multicolumn{3}{|c|}{ Internal surface area } & \multirow{2}{*}{$\underset{(\%)}{\operatorname{Organic}}$} \\
\hline & & $\begin{array}{c}\mathrm{CO}_{2} \\
\left(\mathrm{~m}^{2} / \mathrm{g}\right)\end{array}$ & $\begin{array}{c}\mathrm{N}_{2} \\
\left(\mathrm{~m}^{2} / \mathrm{g}\right)\end{array}$ & $\mathrm{CO}_{2} / \mathrm{N}_{2}$ & \\
\hline $01 \mathrm{Cl}$ & 2182.25 & 39.3 & 1.50 & 26.2 & 14.03 \\
\hline $02 \mathrm{Cl}$ & 2191.15 & 27.0 & 1.33 & 20.4 & 10.29 \\
\hline $03 \mathrm{Cl}$ & 2220.30 & 20.4 & 1.26 & 16.2 & 7.03 \\
\hline $.04 C 1$ & 2230.20 & 13.8 & 5.00 & 2.8 & 1.64 \\
\hline $05 \mathrm{Cl}$ & 2240.10 & 13.8 & 1.04 & 13.2 & 5.81 \\
\hline $06 \mathrm{Cl}$ & 2250.00 & 14.5 & 8.71 & 1.7 & 0.66 \\
\hline $07 \mathrm{Cl}$ & 2260.30 & 31.3 & 1.52 & 20.6 & 12.30 \\
\hline $08 \mathrm{Cl}$ & 2270.30 & 11.8 & 1.43 & 8.5 & 5.04 \\
\hline $09 \mathrm{Cl}$ & 2280.00 & 11.1 & 1.05 & 10.6 & 5.39 \\
\hline 1001 & 2290.75 & 14.7 & 1.08 & 13.6 & 9.23 \\
\hline $11 \mathrm{Cl}$ & 2299.75 & 12.7 & 0.92 & 13.8 & 7.43 \\
\hline $12 \mathrm{Cl}$ & 2310.50 & 10.0 & 1.04 & 9.6 & 5.67 \\
\hline $13 \mathrm{Cl}$ & 2318.80 & 14.3 & 0.82 & $1 / .4$ & 7.30 \\
\hline
\end{tabular}


TABLE 29-INTERNAL SURFACE AREA VALUES

FOR SHALE SAMPLES FROM CORE O1IL

\begin{tabular}{|c|c|c|c|c|c|c|}
\hline \multirow{2}{*}{\multicolumn{2}{|c|}{ Sample number }} & \multirow{2}{*}{$\begin{array}{l}\text { Depth to } \\
\text { top of } \\
\text { sample } \\
(f t)\end{array}$} & \multicolumn{3}{|c|}{ Internal surface area } & \multirow[b]{2}{*}{$\begin{array}{c}\text { Organic } \\
(\%)\end{array}$} \\
\hline & & & $\begin{array}{c}\mathrm{CO}_{2} \\
\left(\mathrm{~m}^{2} / \mathrm{g}\right)\end{array}$ & $\begin{array}{c}\mathrm{N}_{2} \\
\left(\mathrm{~m}^{2} / \mathrm{g}\right)\end{array}$ & $\mathrm{CO}_{2} / \mathrm{N}_{2}$ & \\
\hline $01 \mathrm{~L} 2$ & & 1576.0 & 27.3 & 27.4 & $\sim 1.0$ & 0.43 \\
\hline 03L 1 & & 1589.4 & 12.7 & 12.1 & $\sim 1.0$ & 0.29 \\
\hline $04 \mathrm{LL}$ & & 1602.0 & 11.8 & 11.8 & 1.0 & 0.80 \\
\hline $05 \mathrm{LI}$ & & 1615.1 & 16.6 & 17.8 & 0.93 & 0.28 \\
\hline $07 \mathrm{~L} 1$ & & 1631.6 & 10.1 & 8.4 & 1.2 & 0.15 \\
\hline 09L1 & & 1647.4 & 22.8 & 23.5 & $\sim 1.0$ & 0.32 \\
\hline $09 \mathrm{~L} 2$ & “. & 1656.2 & 23.3 & 23.4 & $\sim 1.0$ & 0.55 \\
\hline $10 \mathrm{Ll}$ & & 1657.6 & 16.4 & 12.6 & 1.3 & 1.28 \\
\hline $11 \mathrm{Ll}$ & & 1667.5 & 30.2 & 20.3 & 1.5 & 2.90 \\
\hline $12 \mathrm{~L} 1$ & & 1678.6 & 30.8 & 25.7 & 1.2 & 1.72 \\
\hline $13 \mathrm{~L} 1$ & & 1688.0 & 31.2 & 25.7 & 1.2 & 2.90 \\
\hline $14 \mathrm{Ll}$ & & $1648, \%$ & 31.5 & 19.0 & $1: 7$ & 4.26 \\
\hline $15 \mathrm{~L} 1$ & & 1710.0 & 34.4 & 11.8 & 2.9 & 7.54 \\
\hline $16 \mathrm{Ll}$ & & 1723.4 & 34.0 & 8.3 & 4.1 & 9.39 \\
\hline $17 \mathrm{I} 1$ & & 1730.6 & 25.9 & 5.5 & 4.7 & 6.50 \\
\hline $18 \mathrm{~L} 1$ & & 1740.2 & 20.5 & 6.0 & 3.4 & 5.57 \\
\hline $19 \mathrm{9T.1}$ & & 1753.5 & 25.1 & 6.2 & 4.1 & 6.28 \\
\hline $20 L 1$ & & 1763.3 & 19.3 & 11.5 & 1.7 & 3.09 \\
\hline $21 \mathrm{LL} 1$ & & 1776.2 & 22.6 & 11.5 & $\sim 2.0$ & 3.79 \\
\hline
\end{tabular}


TABLE 30-INTERNAL SURFACE AREA VALUES

FOR SHALE SAMPLES FROM CORE O2IL

\begin{tabular}{|c|c|c|c|c|}
\hline \multirow[b]{2}{*}{ Sample number } & \multirow{2}{*}{$\begin{array}{l}\text { Depth to } \\
\text { top of } \\
\text { sample } \\
\text { (ft) }\end{array}$} & \multicolumn{3}{|c|}{ Internal surface area } \\
\hline & & $\begin{array}{c}\mathrm{CO}_{2} \\
\left(\mathrm{~m}^{2} / \mathrm{g}\right)\end{array}$ & $\begin{array}{c}\mathrm{N}_{2} \\
\left(\mathrm{~m}^{2} / \mathrm{g}\right)\end{array}$ & $\mathrm{CO}_{2} / \mathrm{N}_{2}$ \\
\hline $01 \mathrm{Cl}$ & 3011.4 & 18.9 & .15 .7 & 1.2 \\
\hline $02 \mathrm{Cl}$ & 3021.4 & 10.7 & 8.0 & 1.3 \\
\hline $03 C .1$ & 3043.3 & 21.6 & 1.9 & 11.2 \\
\hline $04 \mathrm{Cl}$ & 3053.0 & 21.5 & 1.9 & 11.3 \\
\hline $04 \mathrm{C} 2$ & 3059.5 & 23.9 & 2.3 & 10.3 \\
\hline $05 \mathrm{Cl}$ & 3065.3 & 24.5 & 2.1 & 11.9 \\
\hline $06 \mathrm{C} 1$ & 3073.4 & 19.4 & 2.3 & 8.4 \\
\hline $07 \mathrm{Cl}$ & 3085.5 & 12.1 & 5.3 & 2.3 \\
\hline $08 \mathrm{Cl}$ & 3096.5 & 22.8 & 6.0 & 3.8 \\
\hline
\end{tabular}


the inorganic matter or to cause dehydroxylation of the clay minerals, the weight-loss is attributable to loss of organic matter. The nongaseous, higher molecular weight organic material migrates from the pores at the higher outgassing temperature, thus opening up some of the ultramicropores and producing higher $\mathrm{N}_{2}$ ISA values without markedly influencing the $\mathrm{CO}_{2}$ ISA values.

Although the measurements with $\mathrm{N}_{2}$ and $\mathrm{CO}_{2}$ are important in gaining an understanding of the differences in ultramicroporosity that exist among shale samples which, in turn, influence the rates of diffuslun uf containcd gases, these measurements do not reveal sufficient information to characterize the total porosity and the gas-holding capabilities of the shales. The ultramicropores provide considerable surface area but do not necessarily contribute heavily to the total pore volume. The gas-holding capacity of a given shale will be governed by the total pore volume and by additional larger pures in the shale that do not contribute greatly to the 1SA values. The high-pressure methane sorption isotherms provide supplemental informaclun lin this regard.

Figure 41 shows methane adsorption isotherms for three samples from the Kentucky core. Sample $01 \mathrm{Cl}$ gave the largest $\mathrm{CO}_{2} / \mathrm{N}_{2}$ ISA ratio (26.2), sample 06C1 gave the smallest (1.7), and sample 03C1 was intermediate (16.2). Again, these isotherms reflect the extent of the presence of ultramicroporosity, reaching a limiting value rather quickly when there is restriction in the build-up of the adsorbed methane layer in ultramicropores, as shown in figure 41 for samples $01 \mathrm{Cl}$ and $03 \mathrm{Cl}$. With larger pores there is less restriction in the build-up of the adsorbed methane layer with increasing pressure, as shown by sample $06 \mathrm{C} 1$ in figure 41 .

Although data are not yet sufficient to permit extensive interpretation, it appears that the lighter, grayer shales are capable of hululug more gas than the darker shales. Because the porosity in the darker shales in partly occupled by nongaseous organic material, a decrease in gas-holding capability is expected. Whellies vi hut the gray chalos artilally hold more gas at depth of burial than the darker shales in the stratigraphic unit is another issue.

TABLE 31-TNTERNAL SURFACE AREA VALUES AFTER DIFFERENT OUTGASSING TEMPERATURES FOR SAMPLE O1C1 FROM I'HE CHRISTIAN COUN'I'Y, KENTUCKY, CORE $(01 K Y) *$

\begin{tabular}{ccccc}
\hline & & $\mathrm{ISA}$ & & \\
$\begin{array}{c}\text { Temperature } \\
\left({ }^{\circ} \mathrm{C}\right)\end{array}$ & $\begin{array}{c}\mathrm{CO}_{2} \\
\left(\mathrm{~m}^{2} / \mathrm{g}\right)\end{array}$ & $\begin{array}{c}\mathrm{N}_{2} \\
\left(\mathrm{~m}^{2} / \mathrm{g}\right)\end{array}$ & $\mathrm{CO}_{2} / \mathrm{N}_{2}$ & $\begin{array}{c}\text { Weight } \\
\text { loss }(\%)\end{array}$ \\
110 & 39.3 & 1.50 & 26.2 & $\sim 1.0$ \\
230 & 44.3 & 1.57 & 28.2 & $\sim 2.0$ \\
340 & 35.8 & 6.46 & 5.5 & $\sim 6.0$ \\
\hline
\end{tabular}

*Duration of outgassing was $3 \mathrm{hr}$ 
Table 32 shows density and porosity values for three samples selected from the Sangamon County, Illinois, core. The first sample (01L2), which had the lowest $\mathrm{CO}_{2} / \mathrm{N}_{2}$ ISA ratio (about 1.0 ), yielded a density in helium of 2.73. The density in mercury, which yields a particle density without significant pore penetration, was 2.37. Thus, the porosity of this sample was 13.3 percent. By the same methods, sample $15 \mathrm{~L} 1$ was found to have a porosity of 10.5 percent, and sample 17L1-the darkest sample in this corehad a total porosity of 9.7 percent. Similar data for selected samples from the other two cores have not yet been generated.

Methane sorption isotherms at $28^{\circ} \mathrm{C}$ for these three samples are shown in figure 42. Two sets of curves are shown for the three samples; the upper set shows the total methane sorbed by the three samples and the lower set again represents the physically adsorbed component of the total sorption capacity. A limiting value is not reached as quickly in the lower set of curves as it is in the adsorption curves for samples $01 C 1$ and $03 C 1$ from the Kentucky core, shown in figure 41, again indicating the lack of ultramicroporosity in the Sangamon County, Illinois, samples. The total sorption capacity represented by the upper set of curves in figure 42 clearly shows that sample 01L2, having the lowest ultramicroporosity $\left(\mathrm{CO}_{2} / \mathrm{N}_{2}=\sim 1.0\right)$ but the greatest total porosity ( 13.3 percent) of the three samples studied, also has the greatest gas-holding capacity of the three samples. This would be expected solely from the total porosity values.

As a rule of thumb, every foot of depth of burial in sediments increases the pressure 1 psi, according to Hubbert and Willis (1957). At $1700 \mathrm{ft}$ burial depth, the pressure is approximately 115 atmospheres. Extrapolation of the uppermost curve, representing sample 01L2, to 115 atmospheres would yield a sorption value of approximately $10 \mathrm{cc} / \mathrm{g}$, or $320 \mathrm{ft}^{3} / \mathrm{ton}$ shale, as its methane-holding capacity at depth of burial. It is recognized, of course, that moisture and other gases occupy some of the pore volume... It is not to be construed from these data that such large quantities of gas are to be found among the various shale lithologies. The data serve mainly to help characterize the shales, as materials, and to indicate how the actual gas contents differ from the potential gas-holding capacities.

Ultimately, samples from various geographical locations will be similarly examined to cover the gamut of expected lithologies.

TABLE 32-DENSITY AND POROSITY VALUES FOR SELECTED SHALE SAMPLES FROM SANGAMON COUNTY, ILLINOIS, CORE (OIIL)

\begin{tabular}{lcccc}
\hline Sample. & $\begin{array}{c}\text { ISA } \\
\mathrm{CO}_{2} / \mathrm{N}_{2}\end{array}$ & $\begin{array}{c}\text { Helium density } \\
(\mathrm{g} / \mathrm{cs})\end{array}$ & $\begin{array}{c}\text { Mercury density } \\
(\mathrm{g} / \mathrm{cc})\end{array}$ & $\begin{array}{c}\text { Porosity } \\
(\%)\end{array}$ \\
\hline $01 \mathrm{~L} 2$ & $\sim 1.0$ & 2.73 & 2.37 & 13.3 \\
$15 \mathrm{~L} 1$ & 2.9 & 2.56 & 2.29 & 10.5 \\
$17 \mathrm{~L} 1$ & 4.7 & 2.49 & 2.25 & 9.7 \\
\hline
\end{tabular}




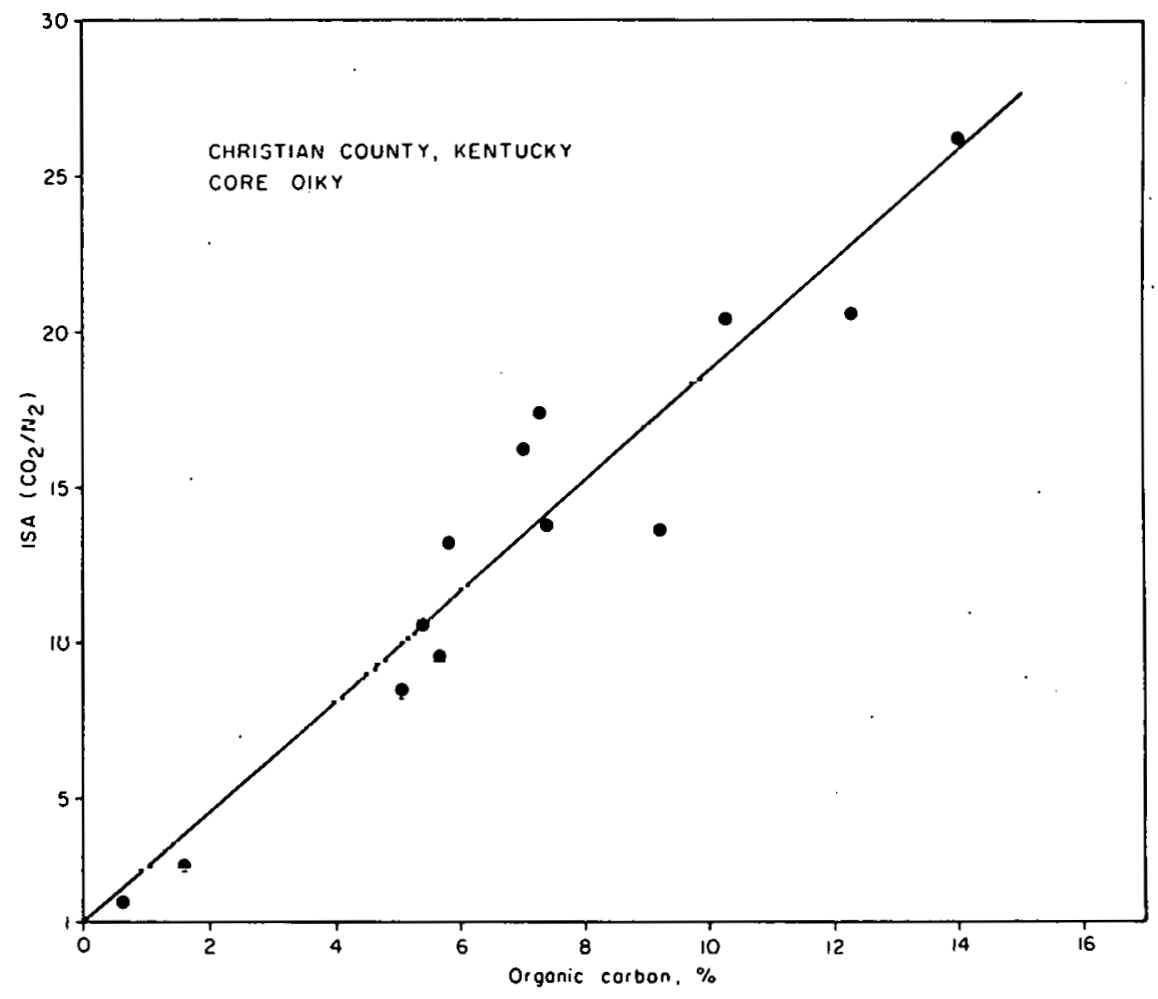

Fig. 39. Relationship between $\mathrm{CO}_{2} / \mathrm{N}_{2}$ ISA and organic carbon content for shale samples from Christian County, Kentucky (core 01KY).

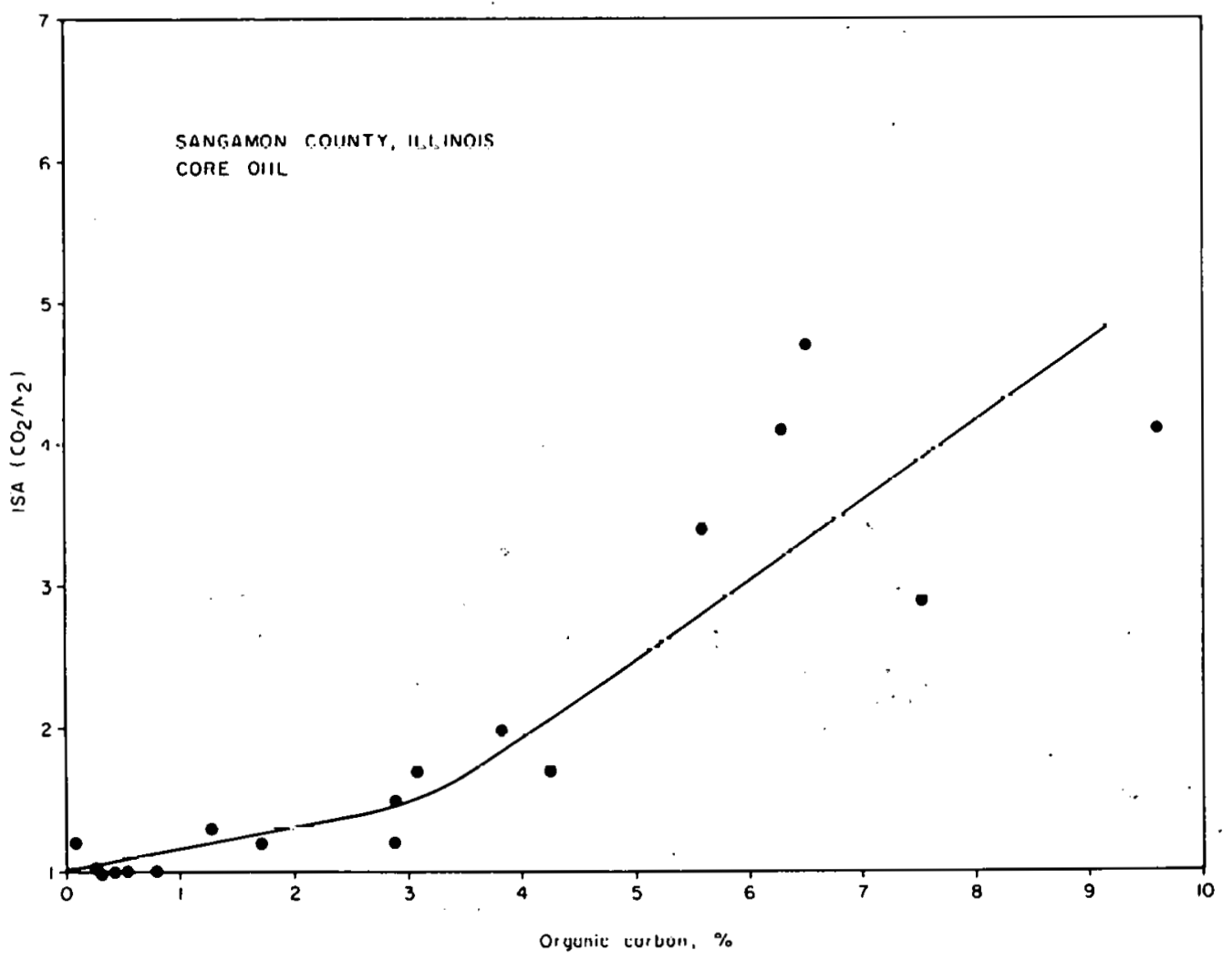

Fig. 40. Relationship between $\mathrm{CO}_{2} / \mathrm{N}_{2}$ ISA and organic carbon content for shale samples from Sangamon County, Illinois (core 01IL). 


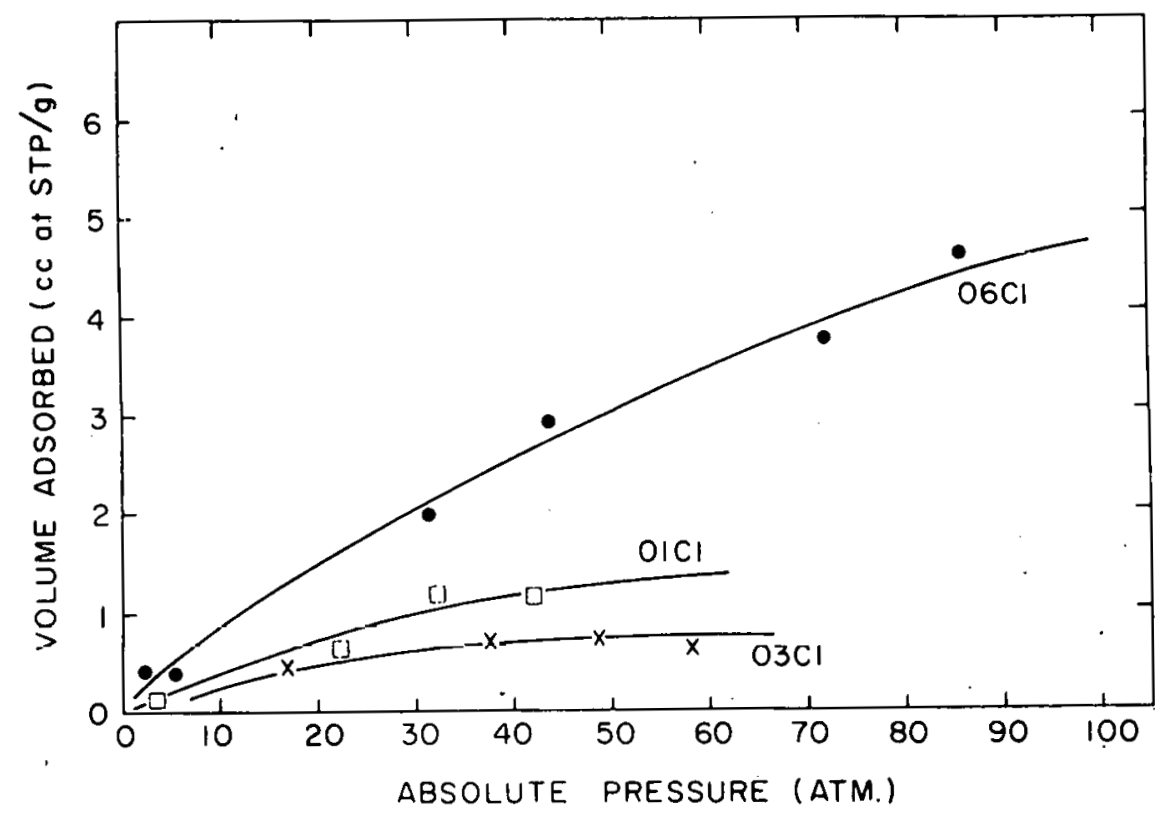

Fig. 41. Methane adsorption isotherms at $28^{\circ} \mathrm{C}$.

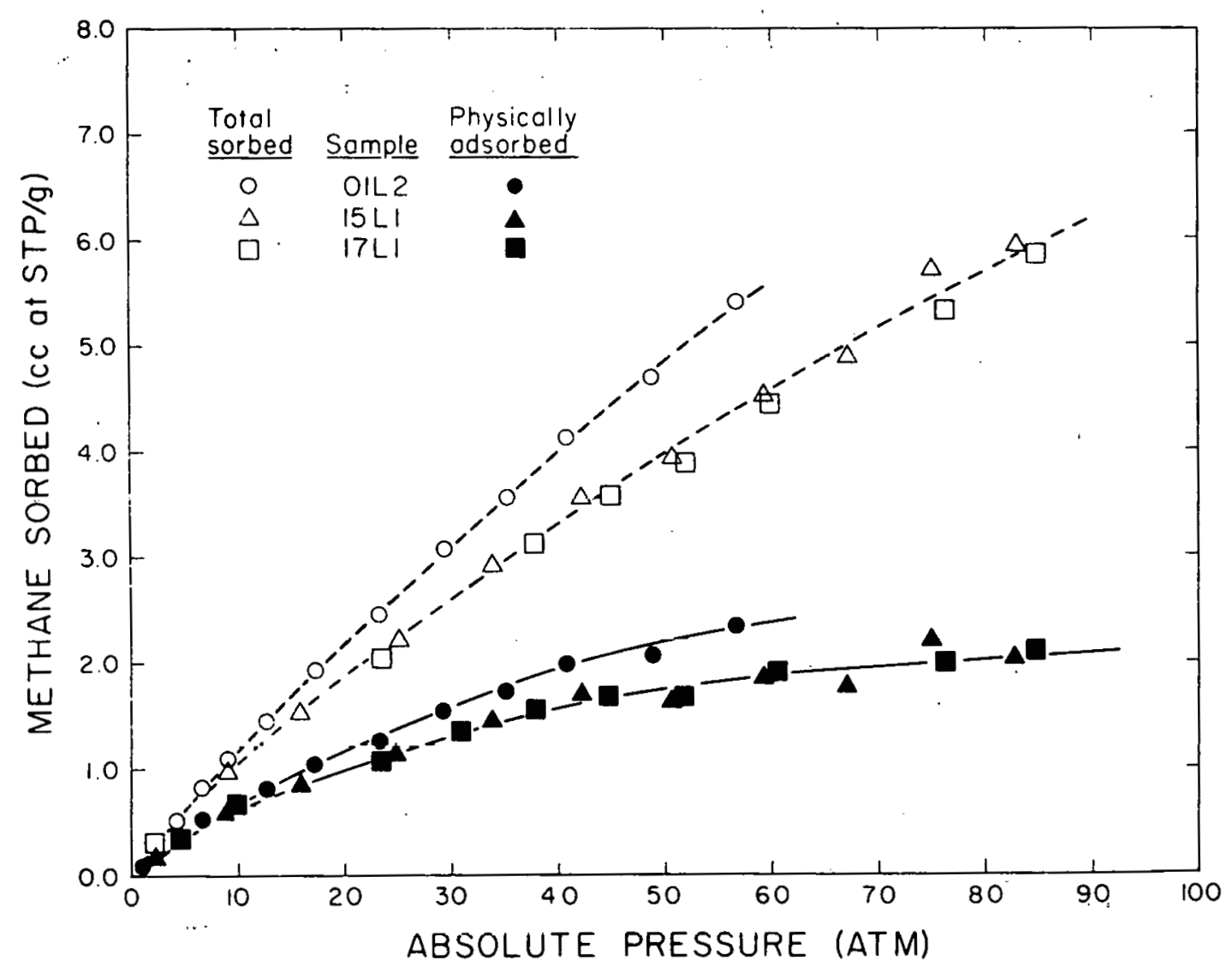

Fig: 42. Methane sorption (and adsorption) isotherms at $28^{\circ} \mathrm{C}$. 


\section{REFERENCES}

Anderson, R. B., W. K. Hall, J. A. Lecky, and K. C. Stein, 1956, Sorption studies on American coals: Journal of Physical Chemistry, v. 60, p. 1548-1558.

Anderson, R. B., J. L. Bayer, and L. J. E. Hofer, 1965, Determining surface areas from $\mathrm{CO}_{2}$ isotherms: Fuel, v. 44, p. 443-452.

Breck, D. W., W. G. Eversold, R. M. Milton, T. B. Reed, and T. L. Thomas, 1956, Crystalline zeolites, I. The properties of a new synthetic zeolite, type A: Journal of the American Chemical Society, v. 78, p. 59635977.

Brunauer, Stephen, P. H. Emmett, and Edward Teller, 1938, Adsorption of gases

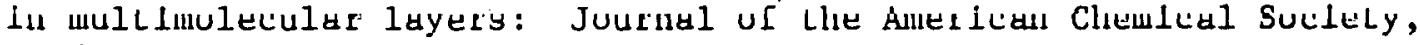
v. 60, p. $309-319$.

Daeschner, H. W., and F. H. Stross, 1962, An efficient dynamic method for surface area determinations: Analytical Chemistry, v. 34, p. 11501133.

Dubinin, M. M., B. P. Bering, V. V. Serpinsky, and B. N. Vasil'ev, 1958, The properties of. substances in the adsorbed state: Studies of gas adsorption over a wide temperature and pressure range, in Surface Phenomena in Chemistry and Biology. Pergamon Press, New York, p. 172-188.

Hubbert, M. K., and D. G. Willis, 1957, Mechanies of hydraulic fracturing: Tranactions of the Society of Petroleum Enginecring of $\Lambda$ IME; $v, 210$, p. $153-168$.

Lamond, T. G., 1962, The sorption of gases on carbons: Ph. $\bar{D}$. thesis, University of Durham, Durham, England.

Nelsen, F. M., and F. T. Eggertsen, 1958, Determination of surface area: Adsorption measurements by a continuous flow method: Analytical Chemistry, v. 30, p. 1387-1390.

Walker, P. L., Jr., and Irwin Geller, 1956, Change in surface area of anthracite on heat treatment: Nature, v. 178, p.-1001. 


\section{Summary and conclusions}

(1) The maximum thickness in Illinois of the entire New Albany Group (fig. 11) is more than $400 \mathrm{ft}$ and occurs in Hardin County, in the extreme southeastern portion of the state. This is apparently near the Devonian center of the Illinois Basin. Thickness distribution patterns for the Blocher, Sweetland Creek, and Grassy Creek Shales in southeastern Illinois are similar to those of the total New Albany Group. The Hannibal-Saverton Shales attain maximum thickness much farther to the northwest in the Petersburg Basin (Workman and Gillette, 1956), which may represent either a structurally negative area or merely a thick sediment wedge with a northwesterly source. Limestone units are also generally thickest in northern and western areas of the New Albany. All shale units are relatively thin on the Vandalia Arch, which represents either a positive area (Workman and Gillette, 1956) or a sediment-starved area.

(2) In general, black shales predominate near the center of the Illinois Basin, whereas greenish gray shales greatly increase in relative prominence away from the Basin's center. Carbonates constitute their greatest relative proportion of the section around the margins of the Basin. Correlation of key horizons suggests that black shales in the center of the Basin are in part contemporaneous with greenish-gray shales on the flanks and with carbonates on the margins of the Basin. In Illinois, this distribution of facies appears to be roughly concentric around the center of the Basin.

(3) Four distinctive shale lithofacies have been defined on the basis of depositional characteristics. These are:

Type I : bioturbate greenish-gray mudstones.

Type II : indistinctly bedded olive-gray shales.

Type III: poorly laminated brownish-black shales.

Type IV : finely laminated brownish-black shales.

Each of these lithofacies has been subdivided into two categories on the basis of diagenetic and other secondary characteristics.

(4) Oxygenation of the bottom environment was the primary factor controlling the deposition of these lithofacies. The finely laminated black shales (Lithofacies IV) of the Grassy Creek and Blocher Shales were deposited in an anaerobic bottom environment in which benthic invertebrates were unable to survive. The interbedded laminated black shales (Lithofacies III) and moderately bioturbated greenish-gray shales (Lithofacies II) of the Sweetland Creek Shale suggest deposition in a transitional anaerobic-to-dysaerobic zone. The extensively bioturbated gray and greenish-gray shale (Lithofacies I) of the Hannibal and Saverton Shales lack calcified benthic invertebrates and were deposited in a dysaerobic environment. Limestones above, below, and within the New Albany Group contain invertebrate faunas and were deposited in aerobic environments. 
(5) The observed stratigraphic relationships and facies distribution in the Illinois Basin suggests a consistent pattern of shale deposition in a stratified anoxic basin. Onepossible model for New Albany deposition is a deepwater stratified basin, in which limestone was deposited in shallow, welloxygenated areas; greenish-gray mud was deposited in deeper, poorly oxygenated areas; and black shale was deposited in the deepest portions. Fluctuations in the level of the anaerobic/dysaerobic boundary would have resulted in the expansion or contraction of black shale deposition across the basin.

An alternative model, in which black shale deposition is independent of water depth, has also been proposed by Lineback (1970). In this model, black shale deposition is controlled by the presence or absence of a floating algal mat at the surface of the sea. Two lines of evidence supporting this model are: (1) the abundance of sapropelic organic matter (probably of algal origin) in the black shales; and (2) the persistence of black shale facies over relatively positive areas, such as the Vandalia Arch.

Neither model is entirely satisfacluly, and fulcher delailed sludy of regional facies relationships are necessary to relate lithologic and geochemical properties to the depositional setting of the Illinois Basin.

(6) The mineral content does not vary widely among the samples from the 01KY and 01IL cores. The silt-sized grains are predominantly quartz with microcline and/or plagioclase feldspars present in most samples as minor constituents. Dolomite occurs as a minor mineral in most of the samples, as do muscovite mica and pyrite. Basaluminite $\left[\mathrm{Al}_{4} \mathrm{SO}_{4}(\mathrm{OH})_{10} \cdot 5 \mathrm{H}_{2} \mathrm{O}\right]$ occurs in the two lowermost samples studied in the Kentucky core. The predominant clay mineral in both cores is illite; some mixed-structure clay is also present in virtually all samples. Chlorite is a minor clay mineral found only in samples from the Illinois core. No káolinite was detected in any of the samples. Mineral compositions vary somewhat between lithofacies, but no trends are yet apparent.

(7) Synaeresis joints were observed in many of the samples from the UIKY and UIL cores. Pyrite occurs along short and crooked synaeresis joints formed during early diagenesis, and calcite occurs along the few long and straight synaeresis joints formed during late diagenesis. The form and distribution of pyrite differs systematically and strikingly among some samples. These relationships probably indicate differences in the early diagenetic environment of the shale.

(B) The strength of the shales from the shallower cores obrained to this date is very low. These cores generally have high moisture contents, are highly fractured, and slake badly during core preparation. The deeper cores are generally stronger, have lower moisture contents, and do not pose significant problems during handling. These differences probably reflect the depth of burial, degree of lithification, lithologic facies changes, and post-depositional history.

(9) Organic matter, dispersed in the dark gray and black shales, is mainly spore and amcrphous (sapropelic) material. Minor amounts of vitrinite and traces of inertinite particles are widely dispersed in the samples. The reflectance of vitrinite particles average about 0.4 percent in the 0lIL core and about 0.5 percent in the $01 \mathrm{KY}$ core. This range of reflectance corresponds to a transitional stage between early methane and oil generation, resulting 
from low temperature reactions. Generally, the samples studied would be classed as immature or barely mature. The relationships between hydrocarbon composition and isotopic data generally support this interpretation. The main phase of gas generation occurs at much higher levels of maturity, corresponding to vitrinite reflectances above about 0.7 percent.

Because the degree of thermal maturation is related to depth of burial, to time of burial, and to geothermal gradient, the high levels of maturity necessary for significant gas production are most likely to be found in the deeper portions of the Illinois Basin.

(10) Internal surface area measurements with nitrogen and carbon dioxide on some 50 shale samples to date from three different cores from the Illinois Basin reveal significant differences in their micropore structures. Nitrogen (at $-196^{\circ} \mathrm{C}$ ) cannot penetrate pores having diameters less than about 4.5 to 5.0 angstroms, whereas carbon dioxide (at $-77^{\circ} \mathrm{C}$ ) can. There is a greater proportion of ultramicropores (less than $5.0 \AA$ in diameter) in the organic-rich darker shales-the proportion increasing as the organic carbon content increases. The organic matter occupies and lines pores in shale, thereby effectively reducing pore diameters. The diffusion rates of gases contained within such ultramicropores will be greatly decreased in comparison with diffusion rates of gases contained within larger pores. The organic material can be partially removed at elevated temperatures, which results in an opening up of some of the ultramicropore structure.

(11) The limited data obtained thus far indicate that the lighter gray shales have more total porosity than the darker shales. The lighter shales thus have greater gas-holding capacities than the darker shales, as high-pressure methane sorption isotherms show for selected samples. Because the darker shales are more likely to be source rocks for gas, areas where gray and black shales are interbedded or interfingered may be particularly favorable areas for exploration and deserve further study.

(12) The gas release data so far has been derived from only two wells and is unique for each well. The gas from the OlKY (Christian County, KY) well contains a much higher percentage of methane relative to other hydrocarbons than does the gas from the 02IL (Effingham County, IL) we11. The 02IL well is in an oil-producing area while the $01 \mathrm{KY}$ well is not. This may or may not account for the difference in methane content. Generalizations about relationships for one well or for wells in a given basin may not be valid when based on data from only two wells. A more valid assessment of the gas resource of the Devonian shale would require data from many more wells in the basin.

\section{REFERENCES}

Lineback, J. A., 1970, Stratigraphy of the New Albany Shale in Indiana: Indiana Dept. of Natural Resources, Geological Survey, Bulletin no. $44,73 \mathrm{p}$.

Workman, L. E., and T. Gillette, 1956, Subsurface stratigraphy of the Kinderhook series in Illinois: Illinois State Geological Survey, Report of Invest1gations no. $1.89,46 \mathrm{p}$. 


\title{
Appendix A: Annotated bibliography of the New Albany Shale and its equivalents in Illinois
}

\author{
Compiled by Mark Reinbold \\ October 1976
}

Armon, W. J., and 0. W. Rees, 1960, Chemical evaluation of Illinois oil shales: Illinois State Geological Survey Circular 307, 22 p.

Nothing on New Albany Shale, but perhaps worth knowing about anyway.

Ball, J. R., 1952, Geology and mineral resources of the Carlinville quadrangle: Illinols State Geological Survey Bulletin 77, $110 \mathrm{p}$.

Brief comments on lithology, thickness, and age of Grassy Creek Shale (classifled liele as Luwel filssisslpplall). Llst uf deep wells, ciusssection.

Bandy, J. C., 1950, Geology of the McKinley poo1, Washington County, Illinois: M. A. thesis (unpub.), University of Illinois, 24 p., 3 pls. (in Survey open-file reports).

Brief mention of New Albany Shale. Includes structure map on top of Devonian, two E-log cross-sections.

*Barrett, N. 0., 1922, Notes on Illinois bituminous shales, including results of their experimental distillation: Illinois State Geological Survey Bulletin 38, p. 441-460; Illinois State Geological Survey Extract Bulletin $38 \mathrm{~F}, 20 \mathrm{p}$.

Includes some data on New Albany equivalents from southern Illinois.

Bassett, C. G., 1924, The stratigraphy of the Devonian Formations of the Alto Pass quadrangle, Hllinois: A..M. thesis, University of 11 inois, $36 \mathrm{p}$. (in Survey open-file reports).

Brief consideration of Mountain Glen Shale-lithology, fauna, correlation. Includes correlation chart, areal geology map of Devonian formations.

Bassett, C. G., 1925, The Devonian strata of the Alto Fass quadrangle: I11inois Academy of Sclence Transactions, v. 18, p. 360-368.

Brief description of lithologic character and outcrop of the Mountain Glen Shale in the Alto Pass quadrangle. Tentative correlation with upper part of New Albany and Chattanooga Shales.

Baxter, J. W., and G. A. Desborough, Areal geology of the Illinois fluorspar district. Pt. 2, Karbers RIdge and Rosiclare quadrangles: Illinois State Geological Survey Circular 385, 40 p.

Mentions New Albany Group-outcrop area, lithology, composition, thickness. Geologic quadrangle map.

*Denotes Important paper. 
Be11, A. H., 1935, Natural gas in Eastern Interior coal basin, in Geology of natural gas: American Association of Petroleum Geologists, p. 813-842. Brief mention of New Albany Shale-correlated in part with Sweetland Creek, Grassy Creek, and Chattanooga Shales. Includes cross-section, structure map of Illinois Basin on base of New Albany.

Bell, A. H., 1938, Possible producing strata existing below the McClosky in Illinols: 0i1 and Gas Journa1, v. 37, no. 5, p. 30-31: I1linois State Geological Survey Circular 38,4 p.

Brief mentions of New Albany Shale. Structure map of Illinois Basin on base of New Albany. New Albany appears in generalized stratigraphic columns and a NE-SW cross-section across Illinois Basin.

Be11, A. H., 1943, Subsurface structure of the base of the Kinderhook-New Albany Shale in central and southern Illinois: Illinois State Geological Survey Report of Investigations 92, $13 \mathrm{p}$. Includes structure map for much of Illinois on base of New Albany Shale.

Bell, A. H., 1955, 011 resources and possibilities in Illinois: Illinois State Geological Survey, Illinois Petroleum 72, 12 p. Structure contour map on the base of the New Albany Shale for central and southern Illinols.

Benson, R. H., and C. W. Collinson, 1958, Three ostracode faunas from Lower and Middle Mississippian strata in southern Illinois: Illinois State Geological Survey Circular 255, 26 p.

Brlef mentions of Grassy Creek and Hannibal Shales as New Albany equivalents. Section descriptions include black shales.

Boos, C. M., 1921, Geology of the Dongola quadrangle: Master's thesis (unpub.), $53 \mathrm{p}$. (In Survey open-file reports).

Brief mention of Mountaln Glen Shale 1ithology. Suggested correlation with Chattanooga and Ohio Shales.

*Bradbury, J. C., M. E. Ostrom, and L. D. McVicker, 1955, Preliminary report on urantum in Hardin County, Illinois: Illinois State Geological Survey Circular 200, 21 p.

Data on uranium content of samples from New Albany Shale at Hicks Dome. Includes tabulated analyses.

Butts, C., 1917a, Descriptions and correlations of the Mississippian formations of western Kentucky, Part 1 of Mississippian formations of western Kentucky: Kentucky Geological Survey, 119 p.

Brief consideration of Chattanooga Shale-lithology, thickness, outcrop area, correlated with OhIo and New Albany Shales. Columnar sections.

Butts, C., 1917b, 011 investigations in parts of Hardin, Pope, and Saline Counties: Illinois State Geological Survey Bulletin 35, p. 75-78. Brief consideration of Chattanooga Shale-outcrop, thickness. Structure contour map on Chattanooga Shale.

Butts, C., 1925, Geology and mineral resources of the Equality-Shawneetown area (parts of Gallatin and Saline Counties): Illinois State Geological Survey Bulletin 47, $76 \mathrm{p}$.

Discussion of Chattanooga Shale-distribution, lithology, thickness, fossils, correlation. 
Cady, G. H., 1923, Geology and mineral resources of the West Frankfort and Galatia quadrangles: unpub. report, 217 p., (in Survey open-file reports).

Considers Chattannoga Shale-lithology, thickness, correlation, stratigraphic relations.

Carlton, J. L., 1940, Geology of the Bartelso oil field, Clinton County, Illinois: M. S. thesis (unpub.), 51 p., 4 pls. (in Survey open-file reports).

Brief consideration of Devonian black shale-lithology, thickness, correlation. Includes structure map of oil field on top of Devonian producing horizon.

Collingwood, D. M., contribs. by C. E. Ekblaw and L. E. Workman, 1933, 0i1 and gas possibilities of parts of Jersey, Greene, and Madison Counties: Illluule Stale Clulugleal Survey Repurt of Invesilgalluns 30, $91 \mathrm{p}$. Brief consideration of Sweetland Creek Shale-outcrop, thickness. Regarded as probable petroleum source bed. Includes well records, cross-sections, tabulated thickness data, structure map on base of Osage Group.

Collinson, C. W., 1957, Ordovician, Silurian, Devonian, and Mississippian rocks of western Illinois: Field Trip Guidebook, IIlinois Geological Society, 2/ p.

New Albany Group shown in regional correlation chart (considered Mississippian) and in columnar section (Jersey County).

Collinson, C. W., 1961, The Kinderhookian Series in the Mississippi Valley, in Northeastern Missouri and west-central Illinois: Kansas Geological Society Guidebook, 26th Annual Field Conference; p. 100 109; Illinoio State Geological Survey Reprint 1961-U, 10 p.

Considers Grassy Creek and Saverton Shales as Upper Devonian; discusses lithology, thickness, distribution, correlations. Includes correlation chart, cross-section.

Collinson, C. W., 1964, Western Illinois: 28th Annual Tri-state Field Conference, Quincy, IL, Illinois State Geological Survey Guidebook Series 6, $30 \mathrm{p}$.

Grassy Creek and Saverton Shales appear in generalized columnar section.

*Collinson, C. W., et al., 1967, Devonian of the north-central region, United States, in International symposium on the Devonian System: Alberta Society of Petroleum Geologists, v. 1, p. 933-971.

Fairly excensive discussions of Devonian system in the 111 inois and Central Iowa Basins. Includes distribution and isopach maps, generalized stratigraphic columns, correlation chart, cross-sections, facies maps.

Collinson, C. W., and J. J. Scott, 1958, Age of the Springville Shale (Mississippian) of southern Illinois: Illinois State Geological Survey Circular $254,12 \mathrm{p}$.

Revises stratigraphic classifications in Upper Devonian and Lower Mississippian. Applies name Grassy Creek to shale called New Albany by Workman and Gillette (1956). Dates Grassy Creek Shale and Sylamore Sandstone as Upper Devonian on basis of conodonts. 
Collinson, C. W., A. J. Scott, and C. B. Rexroad, 1962, Six charts showing biostratigraphic zones and correlations based on conodonts from the Devonian and Mississipplan rocks of the Upper Mississippi Valley: Illinois State Geological Survey Circular 328, 32 p., 6 charts.

Conodont zonation places Grassy Creek and Saverton Shales in Upper Devontan. Generalized stratigraphic column and correlation chart.

Collinson, C. W., and D. H. Swann, 1958, Mississippian rocks of western I11inois: Field Trip Guidebook, Geological Society of America, p. 21-52. Brief considerations of New Albany equivalents in western Illinois. Generalized columnar sections.

Collinson, C. W., D. H. Swann, and H. B. Willman, 1954, Guide to the structure and Paleozoic stratigraphy along the Iincoln Fold in western Illinois: Illinois State Geological Survey Guidebook Series 3, 75 p.

Cooper, G. A., 1944, Remarks on the correlation of Devonian formations in Illinois and adjacent states: Illinois State Geological Survey Bulletin 68 , p. 217-222.

Brief mentions of Upper Devonian shales. Includes correlation chart.

Cox, B. B., 1929, Geology and mineral resources of the Quincy and Liberty quadrangles: unpub. report, 114 p. (in Survey open-file reports). Considers Grassy Creek and Saverton Shales-lithology, thickness, distribution, correlation, stratigraphic relations. Includes well records, outcrop descriptions.

Ekblaw, G. E., 1923, Concerning the stratigraphy of the Paleozoic rocks along the Mississippi River between Alton and Warsaw, Illinois: M. S. thesis (unpub.), 54 p. (in Survey open-file reports).

Brief consideration of Grassy Creek Shale-lithology, thickness, paleontology, problems with type section.

Fergusson, W. B., 1965, Stratigraphic analysis of the Upper Devonian and Mississippian rocks between the LaSalle Anticline and Cincinnati Arch: Ph. D. thesis (unpub.), University of Arizona.

Stratigraphic analysis accomplished through use of isopach, 1ithofacies, and structure contour maps.

*Fisher; J. H., 1953, Paleoecology of the Chattanooga-Kinderhook Shale: Ph. D. thesis (unpub.), University of Illinois.

General survey of Chattanooga Shale and equivalents for large area of mid-continent. Considers stratigraphy, tectonic history, paleoecology, and environmental interpretations. Lists of wells and surface sections, lithofacies map, isopach map, paleogeographic map.

Folk, S. H., and D. H. Swann, $1946, \mathrm{~K}$ ing oil field, Jefferson County, Illinois: Illinois State Geological Survey Report of Investigations 119, 27 p. Brief consideration of New Albany Shale character and thickness.

*Grim, R. E., W. F. Bradley, and W. A White, 1957, Petrology of the Paleozoic shales of Illinois: Illinois State Geological Survey Report of Investigations $203,35 \mathrm{p}$.

Includes petrologic data for New Albany Shale samples-clay mineralogy, $X$-ray diffractions, chemical analyses. 
Hoover, W. F., 1944, Correlation of subsurface Devonian of Sandoval Pool, Marion County, Illinols, with Devonian outcrop of southwestern Illinols: American Association of Petroleum Geologists Bulletin, v. 28, no. 10, p. 1528-1542.

Brief mention of New Albany Shale (considered Mississippian). Generalized stratigraphic sections.

Huner, J., 1934, Subsurface stratigraphy of the Devonian of western Illinois: B. S. thesis (unpub.), $19 \mathrm{p}$. (in Survey open-file reports). Brief mentions of Grassy Creek and Sweetland Creek Shale; shown in generalized columnar section, cross-sections.

*James, G. W., 1965, Age and distribution of the Late Devonian Sweetland Creek Shale in western Illinols: B: S. thesis (unpub.), University of Illinois. Considers distribution, thickness, 11thology, stratigraphic relations, conodont biostratigraphy. Includes isopach map, cross-sections, 11st of wells and crossmsectlons.

Keyes, C. R., 1898, Some geological formations of the Cap-au-Gres Uplift: Iowa Academy of Sciences Proceedings, v. 5, p. 58-63. Brief consideration of Grassy Creek Shale-lithology, thickness, outcrop area.

Keyes, C. R., 1914, Serial subdivision of the early Carbonic succession in the continental interior: Iowa Academy of Sciences Proceedings, v. 21, p. 189-193.

Upper Devonian shales shown in correlation chart for states of mid-continent.

Keyes, C. R., 1916, Terranal affinities of original Chouteau Limestone: Iowa Academy of Sciences Proceedings,v. 23, p. 113-118. Briet mention of Grassy Creek and Saverton Shales, which are sald to disappear from the section to the west in Missour1. Includes cross-section.

Keyes, C. R., 1942, Loulsville vs. New Albany black shales in Illinois and Indiana: Pan-American Geologist, v. 79, no. 1, p. 69-70. Considers the name Loulsville Shale to have precedence over the names New Albany, Chattanooga, Grassy Creek, etc. "New Albany is no more."

Krey, F., 1921, Geology, distribution, and occurrence of the potash-bearing shale of Union County: University of Illinois Agricultural Experiment Station Bulletin 232, pt. 2, p. 237-243.

Considers Mountain Glen Shale-lithology, thickness, distribution, potential as potash resource.

Krey, F., 1922, Dongola quadrangle report: Unpub. report, 96 p. (in Survey open-file reports).

Considers Mountain Glen and Kinderhook Shales-lithology, thickness, outcrop areas, fossils, correlation, stratigraphic relations. Considers Mountain Glen Shale as potash shale.

Krey, F., 1924, Structural reconnaissance of the Mississtppi Valley area from 01d Monroe, Missouri to Nauvoo, Illinois: Illinois State Geological Survey Bulletin 45, 86 p.; Missouri Bureau of Geology and Mines, ser. 2, 
v. 18,86 p.

Considers Sweetland Creek (Grassy Creek) Shale to be closely related to the overlying Mississippian rocks, although perhaps Upper Devonian itself. Discusses outcrop area. Includes cross-sections, well records, structure contour map on base of Burlington Limestone (Mississippian).

Lamar, J. E., 1948, Clays and shales of extreme southern Illinois: Illinois State Geological Survey Report of Investigations 128, $107 \mathrm{p}$.

Considers Mountain Glen Shale-lithology, outcrop area. Discusses high potash content, possible value for cement making or fertilizer.

*Lamar, J.'E., 1959, Limestone resources in extreme southern Illinois:' I11inois State Geological Survey Report of Investigations $211,81 \mathrm{p}$. Outcrop areas and thicknesses of New Albany Shale mentioned. Brief consideration of cement-making possibilities. Includes tabulated chemical analyses of clays and shales.

*Lamar, J. E., W. J. Armon, and J. A. Simon, 1956, Illinois oil shales: I11inois State Geological Survey Circular 208, 21 p.

Analyses of Illinois shales for ofl content. Shales of New Albany Group considered. Includes data tables.

Lowenstam, H. A., 1948, Marine poo1, Madison County, Illinois, Silurian reef producer, in J. W. Howell, ed., Structure of typical American oil fields, v. 3: American Association of Petroleum Geologists, p. 153-188; I111nois State Geological Survey Report of Investigations 131, $40 \mathrm{p}$. Brief mention of New Albany Shale stratigraphic relations. Appears in general columnar section and E-log cross-section.

Lowenstam, H. A., and E. P. DuBois, 1946, Marine pool, Madison County, a new type of reservoir in Illinois: Illinois State Geological Survey Report of Investigations $114,30 \mathrm{p}$.

Brief mention of New Albany Shale, appears in E-log cross-sections. Structure map of oil pool on top of Devonian limestone (base of New Albany).

Meents, W. F., and D. H. Swann, 1965, Grand Tower Limestone (Devonian) of southern Illinois: Illinois State Geological Survey Circular 389, 34 p. New Albany Group shales appear in E-log cross-sections.

*Moore, R. C., 1929, Early Mississippian formations of Missouri: Missouri Bureau of Geology and Mines, Ser. 2, v. 21, 283 p.

Discusses Grassy Creek and Saverton Shales in northeastern Missouri and adjacent Illinois-distribution, thickness, lithology, paleontology, correlations. Includes correlation chart, section descriptions.

Moulton, G. F., 1926, Areas for further prospecting near the Martinsville pool, Clark County: Illinois State Geological Survey, Illinois Petroleum 4, p. 1-5.

: Includes structure map on Sweetland Creek Shale.

Moulton, G. F., and A. H. Be11, 1929; Three typical oll fields of the Illinois region, in Structure of typical Amertcan oil fields: American Association of Petroleum Geologists, v. 2, p. 115-141. 
Subsurface structure of Martinsville pool contoured on base of Sweetland Creek Shale.

*Mylius, L. A., 1927, 0il and gas development and possibilities in east-central Illinois (Clark, Coles, Douglas, Edgar, and parts of adjoining counties): Illinois State Geological Survey Bulletin 54, 205 p. Discussion of Sweetland Creek Shale-thickness, lithologic character. Includes chemical analysis and determinations of oil content. Crosssections, columnar sections, well data, structure maps.

*North, W. G., 1969a, The stratigraphy of the formations at and beneath the Middle-Upper Devonian boundary in southern Illinois: Ph. D. thesis, 88 p. (in Survey open-file reports).

Discusses Blocher. Shale and Sweetland Creek Shales in southern Illinoisdistrubution, thickness, lithology, geophysical characteristics, stratigraphic relations. Includes correlation chart, isopach maps, black shale percentage map, E-log cross-sections, list of wells.

*North, W. G., 1969b, The Middle Devonian strata of southeris Illinois: Illinois State Geological Survey Circular 441, 45 p.

Published version of North (1969a; see annotation above.)

Orr, R. W., 1964, Conodonts from the Devonian Lingle and Alto Formations of southern Illinois: Illinois State Geological Survey Circular 361, 28 p. Brief discussion of controversy in naming the black shale which overlies the Alto Formation.

*Ostrom, M. E., M. E. Hopkins, W. A. White, and L. D. McVicker, 1955, Uranium in Illinois black shales: Illinois State Geological Survey Circular 203. Lists uranium percentages for 175 dark gray and black shale samples from Illinois. New Albany Shale and equivalents included in study.

* Parr, S. W. and M. M. Austin, 1021, Totash shales of Illinois: University of Illinois Agricultural Experiment Station Bulletin 232, pt. 1, p. 229-236. Includes chemical analysis of Mountaln Glen Shale.

Payne, J. N., 1940, Subsurface geology of the Iowa (Lower Mississippian) Series in Illinois: American Association of Petroleum Geologists BulleLill, v. 24, nu. 2, p. 225=236; Illinuis stale Geological. Survey Report of Investigations 61 , p. 225-236; disc., L. K. Lee, p. 236. Devonian-Kinderhook shale shown in cross-section from Randolph County to Sullivan County, Indiana.

Pilkin, J. A., 1974, Pre1lminary thui ium daughter cuntour map and profiles of the Hicks Dome area, Hardin County, Illinois: U.S. Geological Survey Open-File Report 74-157, 9 p. (in Survey open-file reports).

Purpose of investigation was to locate outcrops of thorium-rich breccias which might have associated mineralization. Black shales (presumably New Albany Shale) Included in study.

Poor, R. S., 1927, revised 1935, Geology and mineral resources of the Galesburg quadrangle. Revision also covers Monmouth quadrangle: Unpub. report, original $130 \mathrm{p}$., revision $108 \mathrm{p} ., 15 \mathrm{pls}$. (in Survey open-file reports). 
Brief consideration of Sweetland Creek Shale-lithology, thickness, correlation. Includes section descriptions, well records, columnar sections.

Ross, C. A., 1964, Geology of the Paducah and Smithland Quadrangle in Illinois: Illinois State Geological Survey Circular 360, 32 p.

Brief mention of New Albany Group in terms of age (Middle-Late Devonian), lithology, electrical resistivity. Generalized columnar section, well record.

Satterfield, I. R., 1965, Bedrock geology of the Cobden quadrangle: M. S. thesis (unpub.), Southern Illinois University, 159 p., 1 table, 11 figs., 1 p1. (in Survey open-file reports).

Considers Grassy Creek Shale-lithology, outcrop, correlation, thickness, stratigraphic relations. Includes section descriptions, generalized columnar section, E-logs, bedrock geology map.

Savage, T. E., 1908, On the lower Paleozoic stratigraphy of southwestern Illinois: American Journal of Science, Ser. 4, v. 25, no. 149, art: 46, p. 431-443; expanded Illinois State Geological Survey Bulletin 8, p. 103116; Illinois State Geological Survey Extract Bulletin 8, 14 p.

Considers black shale in southwestern Illinois equivalent to New Albany, Chat tanooga, etc. Generalized stratigraphic section description.

Savage,. T. E., 1920a, The Devonian formations of Illinois: American Journal of Science, Ser. 4, v. 49, no. 241, art. 12, p. 169-182.

Brief discussion of Sweetland Creek Shale-lithology, thickness, stratigraphic relations. Generalized columnar sections used to show regional correlations.

*Savage, T. E., 1920b, Geology and economic resources of the Jonesboro quadrangle: Unpub. report, $187 \mathrm{p} ., 3 \mathrm{pls}$. (in Survey open-file reports). Discussion of Mountain Glen Shale-lithology, distribution, thickness, stratigraphic relations, fossils, correlation, geologic map.

Savage, T. E., 1921, Geology and mineral resources of the Avon and Canton quadrangles: Unpub. report, $40 \mathrm{p}$. (in Survey open-file reports). Brief consideration of Sweetland Creek-Kinderhook Shales-1ithology, thickness.

Savage, T. E., 1922(?), revised 1928, Geology and mineral resources of the Vermont quadrangle: Unpub. report, $157 \mathrm{p} ., 3 \mathrm{pls}$. (in Survey open-file reports).

Report consists of original and two revisions. Brief consideration of Sweet land Creek-Kinderhook Shales-1ithology, thickness. Includes well records.

Savage, T. E., 1925, Comparison of the Devonian rocks of Illinois and Missouri: Journal of Geology, v. 33, no. 5, p. 550-558.

Brief mentions of Mountain Glen, Sweetland Creek, and Grassy Creek Shales. First of these is considered Upper Devonian, last two considered Lower Mississippian. Includes Illinois-Iowa-Missouri correlation chart. 
Savage, T. E., J. L. Rich, and R. S. Blatchley, 1916(?), Geology of the Hardinville, Summer, Birds, and Vincennes quadrangles: Unpub. report, $168 \mathrm{p}$. (in Survey open-file reports).

Brief consideration of Sweetland Creek, Kinderhook Shales. Includes well records.

Savage, T. E., and J. A. Udden, 1921, The geology and mineral resources of the Edington and Milan quadrangles: Illinois State Geological Survey Extract Bulletin 38, 96 p.; 1922, Illinois State Geological Survey Bulletin 38, p. 115-208.

Schroyer, C. R., 1922, Notes on potash possibilities in Illinois: Illinois State Geological Survey Bulletin 38, p. 435-440.

Brief mention of Mountain Glen Shale near Jonesboro as a possible potash resource.

Scott, A. J., and C. W. Collinson, 1959, Intraspecific variability in conodonts - Palmatolepis glabra Ulrich and Bassler: Journal of Paleontology, v. 33, no. 4, P. 550-565; Illinois State Geological Survey reprint 1959-M, $6 \mathrm{p}$.

Specimens of $\mathrm{P}$. glabra collected from the Saverton Shale of Illinois are used to illustrate intraspecific variability in conodonts.

Searight, W. V., 1929, Geology and mineral resources of the Beardstown quadrangle: Unpub. report, 296 p. (in Survey open-file reports).

Brief.mention of Sweetland Creek-Kinderhook Shale. Well records.

*Stevenson, D. L., and D. R. Dickerson, 1969, Organic geochemistry of the New Albany Shale in Illinois: Illinois State Geological Survey, Illinois

Petroleum 90, $11 \mathrm{p}$.

Considers potential of New Albany Shale as petroleum source rock. Concludes from organic geochemical data that New Albany was probably source of most Devonian-Silurian oil in Illinois. Includes contour map of organic carbon content of lower 50 feet of New Albany.

Swann, D. H., and A. H. Bell, 1958, Habitat of oil in the Illinois Basin, in L. G. Weeks, ed., Habitat of oil: American Association of Petroleum Geolog1sts, p. 447-472; Illinois State Geological Survey Reprint 1958-W, $26 \mathrm{p}$.

Structure contour map of Illinois Basin on base of New Albany Shale. $\mathrm{NE}-\mathrm{SW}$ cross-section through center of Basin.

Swann, D. H., J, W. Henderson, E. J. Combs, R. E. Esarey, L. B. Freeman, D. J. Jones, and F. T. Thwaltes, 1951, Fucure 011 possibilities of the Eastern Interior Basin: American Association of Petroleum Geologists Bulletin, v. 35, no. 2, p. 486-498; Illinois State Geological Survey Circular 169, $13 \mathrm{p}$.

Structure map of Eastern Interior Basin drawn on base of Chattanooga-New Albany Shale. Cross-section through basin.

* Swanson, V. E., 1960, oil yield and uranium content of black shales: U. S. Geological Survey Professional Paper 356-A, 44 p.

Discusses uranium content of Chattanooga, New Albany, and equivalents. Includes data tables, columnar section of Chattanooga Shale. 
*Thiessen, R., 1921, Origin and composition of certain oil shales: Economic Geology, v. 16, p. 289-300.

Study of Devonian black shales in mid-continent area-origin of organic matter, microscopic properties, potential as oil shales.

Udden,.J. A., 1908, Artesian wells in Peorla and vicinity: Illinols State Geological Survey Bulletin 8, p. 313-334; Illinois State Geological Survey Extract Bulletin 8, 22 p.

Brief mention of Sweetland Creek Shale. Includes well records, columnar sections.

Udden, J. A., 1912, The eastward extension of the Sweetland Creek Shale in Illinois: Illinois Academy of Sciences Transactions (1911), v. 4, p. 103-107.

Discusses occurrences of Sweetland Creek Shale in Illinois. Includes well records, lithologic descriptions.

U1rich, E. 0., 1915, Kinderhookian age of the Chattanooga Series: Geological Soclety of America Bulletin, v. 26, p. 96-99.

Considers Chat tanooga Shale to be Kinderhookian.

*Wanless, H. R., 1929, Geology and mineral resources of the Alexis quadrangle: Illinols State Geological Survey Bulletin 57, 230 p.

Discussion of Sweetland Creek Shale-lithology, thickness, outcrops, stratigraphic relations, correlations. Includes cross-sections, section descriptions, well records.

*Wanless, H. R., 1930, Geology and mineral resources of the Havana quadrangle: Unpub. report, $428 \mathrm{p}$., $139 \mathrm{pls.}$. (In Survey open-file reports). Considers Sweetland Creek Shale-1ithology, thickness, correlations, stratigraphic relations. Includes structure contour maps, well records, etc.

*Wanless, H. R., 1957, Geology and mineral resources of the Beardstown, Glasford, Havana, and Vermont quadrangles: Illinois State Geological Survey Bulletin 82, 233 p.

Discusses Grassy Creek Shale-lithology, thickness, correlation with lower New Albany. Considered as petroleum source rock. Includes records of deep wells, cross-sections.

Weller, J. M., 1936a, Geology and ol1 possib1litles of the Illinois Basin: Illinols State Geological Survey, Illinois Petroleum 27, 19 p. Brief mention of New Albany, Sweetland Creek Shales. Appear in generalized stratigraphic columns, correlated with other basins. Includes structure map of Interior Basin drawn on base of New Albany Shale (Includes note regarding later interpretation).

Weller, J. M., 1936b, "Grassy Creek" Shales:' Illinois Academy of Sciences Transactions (1935), v. 28, no. 2, p. 191-192.

Appears to have been some confusion in original definition of Grassy Creek Shale and its distinction from Saverton Shale. Includes description of original Grassy Creek section. 
Weller, J. M., 1939a, The Mississippian System: Kansas Geological Section 13th Annual Conference Guidebook, p. 131-137.

Brief mention of Mountain Glen Shale in Union County, Illinois.

Weller, J. M., 1939b, Generalized stratigraphic and structure section of Illinois bluffs of Mississippi River from East St. Louis to Thebes and guide to field study in southern Illinois: Kansas Geological Society Guidebook, 13th Annual Field Conference, p. 14-15, 41-56.

Brief mention of Mountain Glen Shale. Generalized cross-sections.

Weller, J. M., 1940, Geology and oil possibilities of extreme southern Illinois: Union, Johnson, Pope, Hardin, Alexander, Pulaski, and Massac Counties: Illinois State Geological Survey Report of Investigations 71 , $71 \mathrm{p}$.

Considers Mountain Glen and New Albany Shales-lithology, thickness, outcrops. Includes generalized columnar section, structure contour maps (horizons near, black shales), well records.

Weller, J. M., 1944a, Devonian System in southern Illinois: I1linois Geological Survey Bulletin 68, p. 89-102; Illinois State Geological Survey

Extract Bulletin 68, p. 89-102.

Mountain Glen Shale considered equivalent to Chattanooga and New Albany. Includes generalized columnar sections.

Weller, J. M., 1944b, Devonian correlations in Illinois and surrounding states: A summary: Illinois State Geological Survey Bulletin 68, p. 205-213. Discusses problem of Upper Devonian vs. Lower Mississippian age of black shales. Comments on lateral and vertical stratigraphic relations. Includes correlation chart.

Weller, J. M., and G. E. Ekblaw, 1940, Preliminary geologic map of part of the Alto Pass, Jonesboro, and Thebes quadrangles, Union, Alexander, and Jackson Counties. Explanation and stratigraphic summary by J. M. Weller: Illinois State Geological Survey Report of Investigations 70, 26 p. Brief consideration of Mountain Glen Shale-11thology, thickness, outcrops. Correlated with part of New Albany Shale. Includes geologic map.

Weller, J. M., R. M. Grogan, and F. E. Tippie, contribs. by L. E. Workman and A. H. Sutton, 1952, Geology of fluorspar deposits of Illinois: Illinois State Geological Survey Bulletin 76, 147 p.

Brief consideration of New Albany Shale-lithology, thickness, outcrups, geologic map.

Weller, J. M., and A. H. Sutton, 1940, Mississippian border of Eastern Interior Basin: American Association of Petroleum Geologists Bulletin, v. 24, no. 5, p. 765-858; correction, no. 6, p. 1133; Illinois State Geological Survey Report of Investigations $62,93 \mathrm{p}$.

Discussion of New Albany Shale Group (considered Lower Mississippian)lithology, outcrop, thickness.

Weller, Stuart, C. Butts, L. W. Cumer, and R. D. Salisbury, 1920, The geology of Hardin County and the adjoining part of Pope County: Illinois State Geological Survey Bulletin 41, 402 p., pt. 1, 2, 4, 5; Illinois State Geological Survey Extract Bulletin 41, $146 \mathrm{p}$.

Structure contour map on top of Chattanooga Shale. 
Weller, Stuart, and Frank Krey, contrib. by J. M. Weller, 1939, Preliminary geologic map of the Mississipplan formations in the Dongola, Vienna, and Brownfield quadrangles: Illinols State Geological Survey Report of Investigations $60,11 \mathrm{p}$.

Brief consideration of Mountain Glen Shale-lithology, thickness, outcrops. Geologic map.

White, W. A., and N. R. O'Brien, 1964, Illinois clay resources for lightweight ceramic block: Illinois State Geological Survey Circular 371, 15 p. Grassy Creek Shale described as poor bonding clay because of its fissility and organic content.

*Whiting, L. L., 1956, Geology and history of oil production in the DecaturMt. Auburn-Springfield area, Illinois: Illinois State Geological Survey Circular 211, 17 p.

Mention of New Albany Shale-thickness, lithology, stratigraphic relations, E-log characteristics. Includes map showing pre-New Albany paleogeography.

Whiting, L. L. and M. O. Oros, 1958, Electric-log cross-section of the Silur1an-Devonian formations of a part of central Illinois: Illinois Academy of Sciences Transactions (1957), v. 50, p. 172-179; Illinois State Geological Survey Reprint 1958-Q, 8 p.

Brief mentions of New Albany, Grassy Creek Shales. Considered source of Devonian-Silurian oil. Structure map on base of New Albany (not very detailed).

Whiting, L. L., and D. L. Stevenson, 1965, The Sangamon Arch: Illinois State Geological Survey Circular 383, 20 p.

New Albany Shale shown in generalized columnar section.

Williams, J. S., 1957, Paleoecology of the Mississippian of the upper Mississippi Valley region, in H. S. Ladd, ed., Treatise on Marine ecology and paleoecology: Geologic Society of America Memoir 67, v. 2, p. 270-324. Considers Grassy Creek and Saverton Shales-lithology, thickness, paleontology, paleoecology.

Willman, H. B., L. E. Workman, and A. H. Be1l, 1949, Guide to field study in southwestern Illinois between Cape Girardeau and St. Louis, Missouri, in Guidebook for 34th Annual Field Conference, American Association of Petroleum Geologists, p. 18-30.

Mountain Glen Shale appears in generalized columnar sections.

Willman, H. B., and others, 1975, Handbook of Illinois Stratigraphy: Illinois State Geological Survey Bulletin 95, 261 p.

New Albany discussed on pages 121-131. Thickness maps of Blocher Shale, Upper Devonian and Kinderhookian columnar sections.

Workman, L. E., 1926, Geological columnar section at Monmouth, Illinois, as revealed by the new deep wells: Illinois Academy of Science Transactions v. 19 , p. 300-305.

Brief consideration of Sweetland Creek Shale 1ithology. Includes columnar section. 
Workman, L. E., 1928, Geology of McLean County, I11inois: Unpub. report, 14 p. (in Survey open-file reports).

Brief consideration of Sweetland Creek Shale-lithology, thickness, correlation.

*Workman, L. E., and Trace Gillette, 1956, Subsurface stratigraphy of the Kinderhookian Series in Illinols: Illinols State Geological Survey Report of Investigations 189,46 p.

Discusses Sylamore, Grassy Creek, Saverton, New Albany-lithology, distribution, thickness, stratigraphic relations. Includes isopach maps, cross-sections, outcrop descriptions, lists of wells, correlation chart.

Workman, L. E., and J. Huner, 1935, Subsurface stratigraphy of the Devonian in western Ilifnois: Illinols Academy of Sclence Transactions (1934), v. 27 , no. 2 , p. 123 .

Only passing mention of Sweetland Creek Shale. 
Appendix B:- Annotated bibliography of the New Albany Shale and its equivalents in the region adjacent to Illịnois

\author{
Compiled by Mark Reinbold \\ November 1976
}

Arnold, C. A., 1929, Petrified wood in the New Albany Shale: Science (new ser), v. 70, p. 581-582.

Ashley, G. H., 1917, 011 resources of black shales of the eastern United States: U.S. Geological Survey Bulletin 641, p. $311-324$; (abs.) Washington Academy of Sciences Journal, v. 7, p. 564-565:

Reconnaissance investigation of oil shales of the eastern United States, including study of samples from Ohio, Indiana, and Kentucky (after Hoover, 1960).

Austin, C. R., 1934, Surface clays and shales of Ohio: Ohio State University Experiment Station Bulletin 81,53 p.

Preliminary report on the physical tests and properties, from a ceramic view, of the Devonian-Mississippian shales (Hoover, 1960).

Ballard, Norva1, 1938, Stratigraphy and structural history of east-central United States: American Association of Petroleum Geologists Bulletin, v. 22 , p. 1519-1559, 3 figs.

Compares Ohio Shale with its correlatives in other states. Correlations and cross-sections are included (Hoover, 1960).

Bassler, R. S., 1911, The Waverlyan period of Tennessee: U.S. National Museum Proceedings, v. 41, p. 209-224.

Correlates the Waverly series of Ohio with the formations of the same age in Tennessee. Regards the Chattanooga Shale as equivalent to Cleveland, Bedford, Berea, and Sunbury of Ohio. Includes correlation chart (Hoover, 1960).

Beers, R. F., 1945, Radioactlvity and organic content of some Paleozolc shales: American Association of Petroleum Geologists Bulletin, v. 29, p. $1-22$.

Black shales containing up to 16 percent organic matter have been found to contain high concentrations of uranium, thorium, and potassium $\left(\mathrm{K}^{40}\right)$. Excellent correlations exist between uranium content, uranium-thorium ratio, and carbon content in individual shale formations (Hoover, 1960).

Blake, V. M., 1910, A paper on the Chattanooga black shale: M. A. thesis, Vanderbilt University.

Bowen, C. H., 1951, Further studies of Ohio coals and oil shales; pt. III, Ohio shales and Channel coals: Ohio State University Studies, Engineering Series, v. 20, no. 1 and Engineering Experimental Station Bulletin 143. Discusses the Ohio Shale potentialities for oil shale use (Hoover, 1960).

*Denotes important paper. 
Branson, E. B., 1944, Devonian of northeastern Missouri: Illinois State Geological Survey Bulletin 68, p. 174-181.

Brief discussion of Grassy Creek Shale-lithology, thickness, correlations. Generalized columnar sections, cross-sections.

Branson, E. B., and M. G. Meh1, 1934, Conodonts from the Grassy Creek Shale of Missouri: University of Missouri Studies, v. 8, no. 3, p. 161-259. Mostly systematic paleontology of conodonts, but includes discussion of Grassy Creek age and correlations. Generalized stratigraphic sections and descriptions.

Breger, I. R., and Maurice Duel, 1955, Geochemistry of uranium-bearing carbonaceous rocks in geologic investigations of radioactive deposits: U.S. Atomic Energy Commission, TEI-540, p. 186-188.

Data collected during research supports the conclusion that the uranium in the Chattanooga Shale is present as a colloidal phase disseminated Lhoughl lle maltix as vigallic matter (Ilouver, 1060).

Brcger, I. R., and J. M. Schopf, 1955, Cermanium and uranium in coalitied wood from Upper Devonian black shale: Geochimica et Cosmochimica Acta, v. 7, p. 287-293.

Some samples of the Cleveland Shale coalified wood show enough detail to be identified with the genus Callixylon. The germanium is believed to have been part of the element constituents of the living wood. The wood probably absorbed uranium with the formation of organo-uranium compounds after replacement of the wood in the scdiments. Tables give quantitative information of the component wood, ash, etc. (Hoover, 1960).

Brown, R. W., 1949, Ecology of nonalgal marine plants: National Research Council, report of the committeo on a treatise on marine ernlngy and paleoecology, 1948-1949, no. 9, p. 105-110.

Discusses brietly the spread of land plants along shores of salt water bodies and even into brackish and marine waters, and their usefulness in ecological studies. Includes annotated bibliography (Hoover, 1960).

Byers, Charles Wesley, II, 1973, Biogenic structures of black shale paleoenvironments (abst.): Dissertation Abstracts Tnternational, v. 34, no. 4, p. 2095B.

Studies Upper Devonian Sonyea Group of New York and Cretaceous Pierre Shale of western interior. Recognizes four biofacies within the black shale facies. Include environmental interpretations.

Cadman, W. H., 1948, The oil shale deposits of the world and recent development in their exploitation and utilization, revlewed to May, 1941: Journal of the Institute of Petroleum, v. 34, p. 109-132.

Reports that yields per ton of Upper Devonian shale from Kentucky and other eastern states are as follows: 16 gallons of oil and 58.6 pounds of $\left(\mathrm{NH}_{4}\right)_{2} \mathrm{SO}_{4}$ (Hoover, 1960).

*Campbe11, Guy, 1946, New Albany Shale: Geological Society of America Bulletin, v. 57, p. 829-908, 3 pls., 7 figs.

Reports on the Devonian-Mississippian shale sequence of Ohio as correlated with rocks of adjacent states, based on a rapid reconnaissance survey, extrapolations from adjacent areas, and literature survey (Hoover, 1960). 
Campbe11, Guy, 1956, New Albany Shale and Kinderhook Series in Indiana (abstr.): Geological Society of America Bulletin, v. 67, p. 1679. Brief consideration of New Albany sequence in Clark County, Indiana. Correlation with sequence in Illinois.

Caster, K. E., 1934, The stratigraphy and paleontology of northwestern Pennsylvania: American Paleontology Bulletin, v. 21, no. 71, 185 p., 12 figs., 2 pls.

The purpose of Caster's study was to correlate the Upper Devonian and Lower Mississippian strata in northeastern Pennsylvania and adjoining parts of Ohio and New York. There is no geologic map, and much more of the report is devoted to a system of stratigraphic'nomenclature proposed by Caster than to rock thickness and comparative-stratigraphic relations. The discussion of the facies problems, however, is very significant for any consideration of the 1ithologic change in Ohio correlation units (Hoover, 1960).

Clifton, H. E., 1956, The carbonate concretions of the Ohio Shale: Ohio Journal of Science, v. 57, p. 114-124.

Report upon field, petrographic, and structural features of the carbonate concretions, with interpretation of their formation (Hoover, 1960).

*Conant, L. C., 1952, Origin of the Chattanooga Shale: U.S. Atomic Energy. Commission, TEI-237, Oak Ridge, TN, 22 p.

Investigation of the geology and uranium content of the Chattanooga Shale in Tennessee and parts of adjacent states (Hoover, 1960).

Conant, L. C., 1953, Chattanooga Shale investigation: U.S. Atomic Energy Commission, TEI-330, Oak Ridge, TN, p. 145-146.

A11 recent analyses suggest that for a north-south airline distance of about 60 miles along the eastern Highland Rim, there is no great difference in uranium content (Hoover, 1960).

*Conant, L. C., and V. E. Swanson, 1961, Chattanooga Shale and related rocks of central Tennessee and nearby'areas: U.S. Geological Survey Professional Paper 357, 91 p., 17 pls., 18 figs., 19 tables.

Comprehensive study-considers lithology, structure, stratigraphy, paleontology, composition, paleogeography, depositional environment, economic uses (including oil shale potential). Includes columnar sections, crosssections, drill hole localities, isopach maps, data tables of composition, etc.

Cooper, C. L., 1947, Kinderhook micropaleontology, in Weller, J. M., (ed.), Symposium on problems of Mississippian stratigraphy and correlation: Journal of Geology, v. 56, p. 353-366; (abstr.) Geological Society of America Bulletin, v. 58, p. 1272-1273, 1947.

"Black shale problems" of the New Albany shale areas are discussed.

Cooper, G. A., et al., 1942, Correlation of the Devonian sedimentary formations of North America: Geological Society of America Bulletin, v. 53, p. 1729-1794.

Discussion of Devonian vs. Mississippian age of black shales. Brief discussions of numerous individual tormations. Includes North American Devontan correlation chart. 
Cross, A. T., and J. H. Hoskins, 1951, Paleobotany of the Devonian-Mississippian black shales: Journal of Paleontology, v. 25, p. 713-728, 7 figs. Reviews the Devonian-Mississippian black shale floral assemblages from the east-central interior of the United States and contrasts them with the typical Devonian and the pre-Pennsylvanian type of later Mississippian flora of North America. Some conclusions based on the geographic distribution of these fossils and on the nature of the fossils themselves are discussed briefly (Hoover, 1960).

Dawson, T. A., 1941, Outcrop in southern Indiana, Pt. 1 of Devonian formations of Indiana: Indiana Division of Geology, 48 p., 4 pls., 20 figs. Discusses New Albany Shale-lithology, distribution, age (Devonian or Mississippian), correlations.

Dorheim, F. H., and D. L. Koch, 1966, Devonian of northern Iowa, Cedar Valley, Shell Rock, and Lime Creek: Koad Log, liri-State 3Uth Annual Geological Field. Conference Guidebook; $45 \mathrm{p}$.

Discusses shales in Upper Devonian Lime Creek formation of Iowa-possibly equivalent to New Albany.

Duden, Hans, 1897, Some notes on the Black Slate or Genesse Shale of New Albany, Indiana: Indiana Department of Geology and Natural Resources Annual Report 21, p. 108-120, 2 p1s.

Discusses New Albany Shale-chemical composition, hydrocarbon potential, source of bitumen.

Ehlers, G. M., E. C. Stumm, and R. V. Kesling, 1951, Devonian rocks of southeastern Michigan and northwestern Ohio: Ann Arbor, MI, Edward Bros., Inc., Geological Society of America Stratigraphy Field Trip, Detroit Meeting, $1951,40 \mathrm{p}$.

Describes stratigraphy, structure, and paleontology of the shale sequence (after Hoover, 1 you).

Engineering and Mining Journal, 1955, Chillicothe is site of first uranium mine in Ohio: Engineering and Mining Journal, v. 156, p. 166.

"Samples of ore (Ohio black shale) from the property owned by $R$. W. Mowery's 0-Ky Mining Co. were assayed by the University of Maryland and reported favorable" (Hoover, 1960).

Esarey, R. E., C. A. Malott, and J. J. Calloway, 1947, Silurian and Devonian formations in southeastern Indiana: Road log, Indiana Geological Field Confcrence Guidebook, 22 p.

D1scusses New Albany Shale-lithology, thickness. Includes section descriptions, generalized columnar section.

Fenneman, N. M., 1927, Abstract of results, resources survey of the Commercial Club of Cincinnati: University of Cincinnati, Institute of Scientific Research, ser. 2, no. 1, 86 p.

Reports that Bucher's early work on the oil shales from Pike County (Oh10) Indicates no Ohio shale beds which yield more than 12.5 gallons per ton; the average obtained was about 6 gallons per ton (Hoover, 1960).

Fisher, R. A. B., 1941, Isopachous maps of the Appalachian geosyncline: University of Illinois, B. A. thesis (unpub.), 15 p., 7 maps. 
Flessa, K. W., 1973, Comparative community ecology of the Chagrin and Bedford Shales (Devonian-Mississippian) Ohio (abstr.): in Northeastern Section, 8th Annual Meeting, Geological Society of America, Abstract, v. 5, no. 2, p. 160 .

Considers faunal assemblages and paleoenvironmental interpretation.

G111, J. W., 1931, A study of colloids in Ohio shales and surface clays: $\mathrm{Ph}$. D. thesis (unpub.), Ohio State University, Department of Ceramic Engineering, $46 \mathrm{p}$.

Girty, G. H., 1898, Description of a fauna in the Devonian black shale of eastern Kentucky: American Journal of Science: (4), v. 6, p. 384-395. Describes fauna, sumarizes literature pertaining to Devonian age of black shales of the eastern interior (after Hoover, 1960).

Glenn, L. C., 1903, Devonian and Carbonfferous formations of southwestern New York: New York State Museum Bulletin 69, p. 957-990.

Th1s paper preclpitated the dispute concerning the boundary line between the Devonian and Mississippian systems. Practically all subsequent work on these formations in New York, Pennsylvania; and Ohio has considered this question (Hoover, 1960).

Gott, G. B., and E. P. Beroni, 1952, Uranium in black shales, 1ignites, and Iimestone in the United States, in U.S. Geological Survey Circular 220, p. 31-35.

Reports a uranium content for the Chattanooga Shale ranging from 0.001 to 0.03 percent (Hoover, 1960).

Grabau, A. W., 1906, Types of sedimentary overlap: Geological Soclety of Amerlca BulletIn, v. 17, p. 567-636; 1905 (abstr.) Sclence (new ser.), v. 21 , p. 991-992.

Grabau was the first writer to suggest a Mississipplan age for the Chattanooga Shale. Discusses depositional environment and time-transgressive nature of black shale deposits (after Hoover, 1960).

Gravin, M. S., 1922, Analytical distillation of typical American shale oils: U.S. Bureau of Mines Report of Investigations 2332.

No specific mention of New Albany Shale, but may be of interest for analytical data.

Grossman, W. L., 1944, Stratigraphy of the Genesee Group: Geological Society of America Bulletin, v. 55, p. 41-76.

Considers the microscopic petrography of these rocks (Hoover, 1960).

Gupta, Sujoy, 1965, Palynology of Grassy Creek and Saverton Shales of Missour1: $\mathrm{Ph}$. D. thesis (unpub.), University of Missouri.

Gutschick, R. C., 1947, Origin of some bitumen in the Devonian-Mississippian black shales and the Eocene Green River Shale (abstr.): Geological Soclety of America Bulletin, v, 58, p. 1185.

The Ozark Dome, Nashville Dome, and Cincinnati Arch were regional oil structures. Erosion caused dissipation of the liquid bitumen. The oil was incorporated in the black muds to account in part for the bituminous content of the Devonian-Misslssipplan black shales (Hoover, 1960). 
Hard, E. W., 1931, Black shale deposition in central New York: American Association of Petroleum Geologists Bulletin, v. 15, p. 165-181.

Describes probable manner of development for typical Paleozoic shales and reviews current theorles of black shale deposition. Believes Upper Devonian bituminous shales of New York to be relatively shallow water deposits. Bituminous content directly related to type of organic material (after Hoover, 1960).

Harris, J.R., and R, E. Esarey, 1941, Structural condj.tions, pt. 2. of The Devonian formations of Indiana: Indlana Division of Geology, $3 \overline{2}$. Includes cross-sections, generalized stratigraphic sections, structure contour maps (many are of oil fields).

Hass, W. H., 1956, Age and correlation of the Chattanooga Shale and Maury Formation: U.S.G.S. Professlonal Paper 286, 47 p., 5 pls., 1 fig., 8 tables. Correlates the black shales by presence of conodonts. Reviews the correlations of Ohio Shale with Chattanooga. Regards Chattanooga Shale as Late Devonian, though the oldcot beda of the formation could be late Middle Devonian. Maury Shale is Mississippian (Kinderhook and possible Osage) (Hoover, 1960).

Hlavin, W. J., 1976, Biostratigraphy of the Late Devonian black shales on the cratonal margin of the Appalachian Geosyncline: Ph. D. thesis, Boston University, 211 p.; Abstract No. 76-21, 285, Dissertation Abstracts International, Sect. B, v. 37, p. 1150-B, Sept. 1976.

Paleoenvironmental analysis, faunal lists. Correlation with European Standard Section. Black shale lithosome considered time-transgressive; Devonian-Mississippian boundary higher in shales tn east than in shales to west.

Holland, F.' R., 1953, Some detailed sections of the New Albany Shale near North Vernon, Indiana: Cincinnati, University of Cincinnati, 78 p., 15 pls., 14 figs.

*Hoover, K. V., 1960, Devonian-Mississippian shale sequence in Ohio: Ohio Division of Geological Survey, Information Circular no. 27, 154 p., 3 pls. Extensive study of Devonian-Mississippian shales in Ohio. Discusses stratigraphy, paleoecology, paleogeography, structure, sedimentary structures, geochemistry, and economic geology. Inçludes generalized stratigraphic column, cross-sections, structure maps, isopach maps. Extensive annotated bibliography of Ohio black shales and correlative units.

Hoskina, J. I1., and A. T. Cross, 1951, Petrifaction flora of the DevonianMississippian black shale: The Paleobotanist (Birbal Sahni Memorial volume), v. 1, p. 215-238.

An analysis of the longer ranging components of the petrification flora occurring in the upper part of the New Albany-Ohio black shale of Eastcentral interior region of the United States. Clarifies the general character of the flora and determines the possible stratigraphic significance (Hoover, 1960).

Huddle, J. W., 1933, Marine fossils from the top of the New Albany. Shale of Indiana: American Journal of Science, ser. 5, v. 25, p. 303-314. 
Considers entire New Albany Shale Devontan based on brachiopods and gastropods. Some statements regarding reglonal correlation.

Huddle,.J. W., 1934, Conodonts from the New Albany Shale of Indiana: Bulletin of American Paleontology, v. 21, no. 72,136 p., 13 pls., 2 figs. Based on conodonts, New Albany Shale considered Devonian-Mississippian. Callixylon newberryi and Devonian brachiopods indicate Devonian age to within 5 or 10 feet of top (after Hoover, 1960).

*I11inols State Geological Survey, 1944, Symposium on Devonian stratigraphy, in Illinois State Geological Survey Bulletin 68, p. 89-222.

Series of papers presented by distinguished authorities dealing with the Devonian stratigraphic units of Illinois and surrounding states (Hoover, 1960).

Jones, M. L., and J. M. Dennison, 1970, Orfented fossils as paleocurrent indicators in Paleozoic lutites of southern Appalachians: Journal of Sedimentary Petrology, v. 40, no. 2, p. 642-649, ilius. Includes consideration of paleocurrents in Chattanooga Shale in northeastern Tennessee.

Kerr, T. H., 1948, Some studies of Ohio coals, shales, and oils: Ohio State University Engineering Experiment Station Bulletin 133, p. 32-44. Considers the Ohio Shale liquid fuel potentials (Hoover, 1960).

Keyes,C. R., 1938, Age of the Chattanooga black shales: Pan-American Geologist, v. 70, p. 346-366.

Suggests that the "Black Shales" may not be a stratigraphic formation. They may be an old oil-gathering zone, now almost dried up, which crosses the bedding indiscriminately, but which, when originally deposited, was parallel with an old erosion surface. In such case there would be great difficulty in working out any sort of nomenclature (Hoover, 1960).

Kindle, E. M., 1899, The Devonian and Lower Carboniferous faunas of southern Indiana and central Kentucky: Bulletin of American Paleontology, v. 3, no. $12,111 \mathrm{p}$.

Brief consideration of New Albany Shale-lithology, thickness, paleontology, currelaliun. Includes section descriptions.

KIndle, E. M., 1901, The Devonian fossils and stratigraphy of Indiana: Indiana Department of Geology and Natural Resources, Annual Report 25, p. 529-758, 773-775, 33 pls.

Discussion of New Albany Shale-lithology, thickness, outcrop area, paleontology. Includes section descriptions.

Klapper, G., and W. M. Furnish, 1962, Conodont zonation of the early Upper Devonian of eastern Iowa: Iowa Academy of Science Proceedings, v. 69, .p. 400-411.

Conodont zonation of Sweetland Creek Shale type section. Includes section descriptions, generalized columnar sections.

Koenig, J. W., 1961, Devonian System: Missouri Division of Geological Survey and Water Resources, v. 40, 2nd series, p. 36-49.

Considers Grassy Creek, Saverton, Chattanooga, and "Kinderhook" Shaleslithology, thickness, stratigraphic relations, correlations: 
Kohout, D. L., and R. J. Malcuit, 1969, Environmental analysis of the Bedford Formation and associated strata in the vicinity of Cleveland, Ohio: Compass, v. 46, no. 4, p. 192-206, illus., table. Environmental analysis. Includes distribution map, generalized columnar section, lithofacies and enviornmental cross-sections.

Krumin, P. 0., 1949, Review of the Estonlan oil shale industry, with a brief account of oil shale development in U.S.: Ohio State University Studies, Engineering Series, v. 18, no. 6, 125 p., 42 figs., 53 tables.

Considers Ohio Shale for its oil potential (Hoover, 1960).

Krumin, P. 0., 1951, Further studies of Ohio coals and oil shales, pt. 1, shales: Ohio State University Studles, Engineering Series, v. 20, no. 1; and Ohio State University Engineering Experiment Station Bulletin 143, 29 p.

Considers Ohio Shalc as an oil shale possibility (Hoover, 1960).

Lamborn, R. E., 1929, Notes on the character and occurrence of the Olentangy Shale in southern Ohio: Ohio Journal of Science, v. 29, p. 27-38, map.

Lamborn, R. E., C. R. Austin, and D. Schaaf, 1938, Shales and surface clays of Ohio: Ohio Geological Survey Bulletin 39, 281 p., 4 pls., maps. Comprehensive treatment of the ceramic qualities of rocks in the DevonianMississippian shale sequence (Hoover, 1960).

Lewis, T. L., and J. R. Schwietering, 1971, Distribution of the Cleveland black shale in Ohio: Geological Society of America Bulletin, v. 82, no. 12, p. 3477-3482, illus. (incl. sketch maps).

Interprets depositional environment. Includes E-log cross-sections, isopach map, etl.

*Lineback, J. A., 1963, Stratigraphy of the New Alhany Shale in southeastern Indiana (abstr.): Geological Society of Amerira Special Paper 76, p. 102-103.

Describes stratigraphic succession, considers age from early Late Devonian to Kinderhookiais, cummenls un depusletonal environ̈ment.

*Lineback, J. A., 1964, Stratigraphy and depositional environment of the New Albany Shale (Upper Devonian and Lower Mississippian) in Indiana: Ph. $\mathrm{n}$. thesis (unpub.), Indiana University, 136 p., 10 pls., 20 figs., 2 tables. Lithologic subdivisions and environmental conditions based on surface sections, subsurface logs, and cores. Correlations with equivalent units in surrounding states. Deoxygenated marine environment of deposition is postulated. Includes photomicrographs, cross-sections, isnpach maps, descriptions of measured sections.

*LIneback, J. A., 1968, Subdivisions and depositional environments of New Albany Shale (Devonian- Mississippian) in Indiana: American Association of Petroleum Geologists Bulletin, v. 52, no. 7, p. 1291-1303, illus. Considers lithology, subdivision, correlations, distribution, depositional environment. Includes maps of shale color, isopachs, section descriptions, etc.

*Lineback, J. A., 1970, Stratigraphy of the New Albany Shale of Indiana: Indiana Geological Survey, Bulletin 44, 73 p. 
Subdivision of New Albany Shale into members. Correlations with equivalent units in neighboring states. Discussion of age. Environmenta1 interpretation. Isopach maps, cross-sections, descriptions of measured sections.

McFarlan, A. C., 1943, Geology of Kentucky: Lexington, KY, Kentucky University, $531 \mathrm{p}$.

Considers the stratigraphy and paleontology of the Devonian-Mississippian shale as represented in Kentucky (Hoover, 1960).

McFarlan, A. C., and W. H. White, 1952, Boyle-Duffin-Ohio Shale relationships: Kentucky Geological Survey Bulletin 10, p. 1-24.

Though the black shales are normally regarded as in an unconformable relation with the underlying formations, these authors appear to be able to demonstrate facies relations with the underlying carbonates (Hoover, 1960).

McGregor, D. J., 1954, Stratigraphic analysis of Upper Devonian and Mississippian rocks in Michigan basin: American Association of Petroleum Geologists Bulletin, v. 38, p. 2324-2356, 17 figs.

Quantitative consideration of the shale sequence as represented in eastern Michigan, using isopach and lithofacies maps to serve as basis for interpreting tectonic and environmental conditions and sedimentation processes. Conclude that tectonic of the depositional area are a very important factor in controlling sedimentary facies (Hoover, 1960).

McKelvey, V. E., and J. M. Nelson, 1950, Characteristics of marine uraniumbearing sedimentary rocks: Economic Geology, v. 45, p. 35-53. Study of marine black shales which are uranium-bearing. These rocks are rich in organic matter and sulfides, and the best are pre-Mesozoic. The urantum is considered syngenetic in origin (after Hoover, 1960).

Martin, H. M., and M. T. Straight, 1956, An index of Michigan geology, 18231955: Michigan Geological Survey Publication 50, 461 p., charts, maps. Bibliographic references to the Devonian-Mississippian strata of Michigan that may be correlated with similar units in Ohio (Hoover, 1960).

Melhorn, W. N., 1958, Revision of the Mississippian-Devonian boundaries in White and Benton Counties, Indiana: Indiana Academy of Science Proceedings, v. 67, p. 194-198, 2 figs.

Brief mentions of New Albany Shale. Includes cross-sections.

Miller, A. K., and W. Youngquist, 1947, Conodonts from the type section of the Sweetland Creek Shale in Iowa: Journal of Paleontology, v. 21, p. 501-517, p1s. 72-75.

Systematic paper on the Sweetland Creek Shale with references to those species common to the Ohio Shale and especially the Olentangy Shale of Ohio (Hoover, 1960).

Miller, Peter, Jr., 1944, A test of the Ohio shale for yield of oil: B. S. thesis (unpub.), Ohio State University, $23 \mathrm{p}$. Presents a series of quantitative assays for oil content. Main purpose of thesis was to develop the best extraction method to obtain optimum oil yield (Hoover, 1960). 
Miller, R. C., 1970, Analysis of sandstones in the Dowelltown Member of the Chattanooga Shale, Macon County, Tennessee and vicinity: Compass, v. 47, no. 2, p. 84-98, tables.

Includes isopach, isolith, sandstone percentage, and other maps for Macon County. Includes data tables.

Mining Engineering, 1951, Uranium - swords or plowshares: Mining Engineering Journal, v. 3, p. 762-766.

Reports that the Chattanooga Shale of Tennessee-Kentucky contains about 0.008 percent $\mathrm{U}_{3} \mathrm{O}_{8}$ (Hoover, 1960).

Morse, W. C., and A. F. Foerste, 1912, Preliminary report on the Waverlian formations of east-central Kentucky and their economic values: Kentucky Geological Survey Bulletin 16, $76 \mathrm{p}$.

Black shale sequence in Kentucky compared to that of Ohio. Possible economic values considered. Includes section descriptions.

Nelson, B. W., 1955, Pre-Berea mineralogy and stratigraphy: Ph. D. thesis (unpub.), University of Tllinois, $104 \mathrm{p}$.

Develops new facies concepts and sedimentation history of the Ohio and Bedford Shales, based on clay mineralogical laboratory and field investigation (Hoover, 1960).

Newberry, J. S., 1860, The rock oils of Ohfo: Ohio State Board of Agriculture, 14th Annual Report, p. 605-618; Advance sheet, 16 p., 1859. Utilization of the black shale.

Newberry, J. S., 1883, On the origin of carbonaceous matter in bituminous shales: Annals of New York Academy of Science, v. 2, p. 357-369.

Newberry, J. S., et. al., 1873, The general geological relations and structures of Ohio: Ohio Geological Survey Vo1. 1, pt. 1, p. 1-167.

Discusses relationship of the black shales to the structural studies of Ohio. Considers the shale series in the various county reports (Hoover, 1260).

Newberry, J. S., et al., 1874, Report of the Geological Survey of Ohio: Geo1ogy: Ohio Geological Survey Vol. 2, pt. 1, 701 p.

Concerns age and corrclations of the Devonian-Mississippian shale ocquence. Diocuooco ocquence by countico in which thoy orop out (after Hoover, 1960).

Newberry, J. S., et al., 1878, Report of the Geological Survey of Ohio: Geology: Ohio Geological Survey Vol. 3, pt. 1, 956 p. General geology by counties.

Includes maps, columnar sections, data tables, etc.

* Ohio Development and Publicity Commission, 1950, Ohia, an empire within an empire: Columbus, Ohio, F. J. Heer Printing Co., 214 p. Gives historical account of the use of the Ohio Shale for distillation of kerosene and discusses future potentials of Ohio Shale as an oil shale (Hoover, 1960). 
Orton, Edward, 1882, A source of the bituminous matter in the Devonian and subcarboniferous black shales of Ohio: American Journal of Science, ser. 3, v. 24, p. 171-175.

Organic matter, which ranges from 8 to 21 percent, suggests that the vegetable spores were the contributors of the bituminous matter of the Ohio black shales (Hoover, 1960).

Orton, Edward, 1883, A source of the bituminous matter of the black shales of Ohio: American Association for the Advancement of Science Proceedings, v. 31 , p. $373-384$.

Orton, Edward, 1886, Preliminary report upon petroleum and inflammable gas: Ohio Geological Survey, 76 p., 2 maps, (abstr.) American Journal of Science, ser. 3, v. 32, p. 241; 1887, reprinted for the author with supplement, 200 p.; 1888, (abstr.), American Geologist, v. 1, p. 62-63. Considers the stratigraph .c aspects and petroleum and gas possibilities of the shale series (Hoover, 1960).

Orton, Edward, 1890, First annual report of the Geological Survey of Ohio (3rd organization): Columbus, Ohio, The Westbote Co., State printers. Considers the stratigraphy of the Devonian-Mississippian shale series and evaluates the Ohio Shale as a source of oil and gas (Hoover, 1960).

Orton, Edward, et al., 1888, Report of the Geological Survey of Ohio: Economic geology: Ohio Geological Survey Vol. 6, 831 p.

Considers black shale in central Kentucky to be the upper or Cleveland division and gives the impression that this opinion is based upon physical criteria and faunal evidence. Considers the Ohio Shale to be a source of oil and gas (Hoover, 1960).

Owen, D. D., 1846, On the geology of the Western States of North America: London Geological Society Quarterly Journal, v. 2, p. 433-477.

Peattie, Roderick, 1923, Geography of Ohio: Ohio Geological Survey Bulletin $27,137 \mathrm{p}$.

Refers to the economic utilization of the Devonian-Mississippian shale sequence in the ceramic and mineral-water industries (Hoover, 1960).

Pohl, E. R., 1930, The black shale series of central Tennessee: American Journal of Science, ser. 5, v. 20, p. 151-152.

Divides Chat anooga Shale of central basin into three units, all separated by unconformities. Lower unit considered Devonian, middle and upper units considered Mississippian. Regional correlations proposed. Considers Mississippian units widespread, but Devonian only locally developed (after Hoover, 1960).

Reeves, J. R., 1922, Preliminary report on the oil shales of Indiana, in Handbook of Indiana Geology: Indiana Department of Conservation Publication 21, pt. 6, p. 1059-1105, 16 pls., 2 figs.

Reports on the New Albany Shale (Hoover, 1960).

Reeves, J. R., 1923a, A section through the New Albany Shale: Indiana Department of Conservation, 4ch Annual Report, p. 18-21.

Top and bottom jortions of New Albany Shale have highest ofl contents. 
Oil-forming matter probably of same composition throughout formation, as indicated by small variation in speciflc gravity. Average oil yield from analyzed core is 8.3 gallons per ton (after Hoover, 1960).

Reeves, J. R., 1923b, Oil shales of Indiana: Indiana University Department of Geology, 92 p. (mimeo.).

Rich, J. L., 1948, Probable deep-water origin of the Marcellus-Ohio-New Albany-Chattanooga black shale: (abstr.), Geological Society of America Bulletin, v. 59, p. 1346-1347.

Cites lines of evidence for deep-water origin of black shales.

Rich, J. L., 1951, Probable fondo origin of Marcellus-Ohio-New Albany-Chattannoga bituminoue chalco: American Assucialiun of Petroleum Geologists Bulletin, v. 34, p, 2017-2040, 1 fig.

Lists dind discusses vlews of various authortties on deep- and shallowwalel Uf lylns of Black shales (Hoover, 1960).

Rominger, C.; 1873-1876, Black shales of Michigan: Michigan Geological Survey Vol. 3, p. 63-67.

Rubarts, W. E., 1959, The Boyle-Duffin-New Albany Relationships (Devonian) in northern Casey and western Lincoln Counties (Kentucky): M. S. thesis (unpub.), Kentucky University.

*Rubey, W. W., 1929, Origin of the siliceous Mowry Shale of the Black Hills region: U.S. Geological Survey Professional Paper 154-D, p. 153-170, 3 pls.

Discusses origin of silica in Mowry Shale. Good analytical study which rnuld serve as bacio for jimilar study u[ Devunlan-Mississipplan shàle sequence (after Hoover, 1960).

Ruedèmann, R., 1934, Conditions of black shale accumulation and general conclusions: Geological Society of America Memoirs 2, p. 43-64. Conçerned sperifirally with graptolito-containing shales. Suiiundilises prevailing interpretations of black shale deposition. The non-calcareous black shale fauna is very unlike that of the limestone and calcareous shales which are found in the same area (after Hoover, 1.960).

Ruedemann, R., 1935, Ecology of black mud shales nf eastẹrn New York: Journal of Paleontology, v. 9, p. 79-91.

Reviews conditions for deposition of h1ack shale. Considers oxygen supply, organic accumulation, and water depth (after Hoover, 1960).

Schemehorn, N. R., 1956, Sedimentation study of (Upper Devonian) New Albany Shale, (Lower Mississippian) Rockford Limestone, New Providence Shale in Indiana: A. M. thesis (unpub.), Indiana University, 39 p., 10 figs.

*Schopf, J. M., 1953, Organic matter of the Chattanooga Shale: U.S. Atomic Energy Comm. TEI-330, p. 146-152.

The general relationship reported between organic content and radioactivity suggests an additional possible means of determining whether a similar relationship exists within the laminae. This is studied with nucleartype autoradiographic films (after Hoover, 1960). 
Schopf, J. M., and J. E. Schwietering, 1969, Littoral control of the Foerstia zone in Upper Devonian Ohio Shale: (abstr.), Geological Society of America Abstract, 1969, pt. 6 (N-Cent. Sect.), p. 42-43.

Considers paleogeographic implications of Foerstia zone.

Schuchert, Charles, 1910a, Paleogeography of North America: Geological Society of America Bulletin, v. 20, p. 427-606.

Schuchert, Charles, 1910b, Biologic principles of paleogeography: Popular Science Monthly, p. 591-560.

Carbonaceous matter of black shales may be of algal origin, but it is far more probable that it is largely of animal origin as suggested by the optical properties which compare with those of animal oil, especially those of fish oil (Hoover, 1960).

Schuchert, Charles, 1915, The conditions of black shale deposition as illustrated by Kupferschiefer and Lias of Germany: American Philosophical Society Trans., v. 54, p. 259-269.

States that widely distributed black shales probably originated in closed arms of the sea, cul-de-sacs, and that some bituminous shales may be the result of "sargasso seas" (Hoover, 1960).

Schuchert, Charles, 1955, Atlas of paleogeographic maps of North America: John Wiley \& Sons, Inc., New York, 177 p.

Includes paleogeographic interpretations of New Albany times.

Schwietering, J.F., 1972, Olentangy Shale (Middle and Upper Devonian) and its equivalents in western parts of Pennsylvania and New York (abstr.), in North-Central Section, 6th Annual Meeting, Geological Society of America Abstract, v. 4, no. 5, p. 350. Suggests presence of unconformity in Olentangy Shale. Correlations, paleogeographic interpretation.

Shaler, N. S., 1877, Notes on investigations of the Kentucky Geological Survey during the years 1873, 1874, and 1875: Kentucky Geological Survey, Report of Progress, v. 3, p. 129-282.

Contains many references to the black shales pertaining to their economic value for building stone, oil content, etc. Regards the ohio Shale as a deep-water deposit (Hoover, 1960).

Sloss, L. L., E. O. Dapples, and W. C. Krumbein, 1960, Lithofacies maps-An atlas of the United States and southern Canada: John Wiley \& Sons, Inc., New York.

Sorgenfrei, Harold, Jr., 1952, Gas production from the New Albany Shale: M. S. thesis (unpub.), Indiana University, $26 \mathrm{p}$.

Stephens, J. G., 1953, A preliminary study of the basal sandy zone of the Ohio-New Albany black shale: M. S. thesis (unpub.), University of Cincinnati.

Stout, Wilber, 1916, Geology of southern Ohio: including Jackson and Lawrence Counties and parts of Pike, Scioto, and Gallia: Ohio Geological Survey Bullet1n 20, $723 \mathrm{p}$. 
Considers the Bedford Shale for each county, particularly its oil and gas potentials (Hoover, 1960).

Stout, Wilber, 1932, Ohio's progress due largely to state's abundant'mineral resources: Pit and Quarry, v. 23, no. 11, p. 31-32.

Discusses stratigraphy and economic use of the Olentangy Shale, Ohio

Formation, and Bedford Formation (Hoover, 1960).

Stout, Wilber, and R. E. Lamborn, 1924, Geology of Columbiana County: Ohio Geological Survey Bulletin 28, 408 p.

Considers the ofl and gas possibilities of the Devonian-Mississippian series (Hoover, 1960).

Strom, K. M., 1936, Land-1ocked waters: Det norske videnskapp-Akademi 1 . Oslo, Nat. Naturv. Klasse, v. 1, no. 7, p. 1-85.

Discussion of circulation, deposition, and life in barred or land-locked basins. Desrribes bays and fjordo (after loover, 1960).

Stugard, Frederick, Jr., D. G. Wyant, and A. J. Gude III, 1951, Secondary uranium deposits in the United States: (abstr.), Geological Society of America Bulletin, v. 62, p. 1542.

Considers reconstituted (secondary) uranium minerals. Most secondary uranium deposits show no apparent relationship to known primary minerals. Successful distinction between secondary deposits resulting from concentration and those resulting from dispersion of primary deposits not made to date (after Hoover, 1960).

Sutton, A. H., 1944, Devonian System in Indiana: Illinois State Ceological Survey Bulletin 68, p. 162-173

Discussion of New Albany Shale-lithology, thickness, stratigraphic rcle tions, age. Includes outcrop distribution map.

Swartz; J. H., 1923, The age and stratigraphy of the (Devonian-Mississippian) Chat anooga black shale of Tennessee: $\mathrm{Ph}$. D. thesis (unpub.), Johns Hopkins University.

Swartz, J. H., 1929, The Devonian-Mississippian boundary in southeastern United STtates: Science, v. 70, p. 609.

Discusses the problem of the probable age of the black shales (Hoover, 1960).

Szmuc, E. J., 1970, The Devonian System: In Guide to the geology of northeastern Ohto, p. 9-20, illus. (incl. sketch maps), Northern Ohio Geological Soctery (Kent), 1970.

Trask, P. D., 1932, Origin and environment of source of petroleum: Houston, Texas, Gulf Publishing Co., 373 p.

Observes that organic content of recent sediments increases in the smaller size fractiuns (Hoover, 1960).

Twenhofel, W. H., 1939, Environments of origin of black shales: American Assoctation of Petroleum Geologists Bulletin, v. 23, p. 1178-1198;

(abstr.), 011 Weekly, v. 93, no. 3, p. 69.

Explanations of origins reviewed; considers origin of black color, depositional environments. 
Udden, J. A., 1899, The Sweetland Creek Beds: Journal of Geology, v. 7, p. $65-78$.

Discussion of Sweetland Creek Shale in Muscatine County, Iowa. Considers lithology, structural relations, fossils, etc. Includes section deccriptions.

United States Atomic Energy Commission, 1954, Geologic Investigations of radioactive deposits: U.S. Atomic Energy Comm., Technical Information Service, Oak Ridge, TN, TEI-440, 250 p.

Extensive discussion of investigations of uranium deposits in the United States. Comments on uranium contents of black shales.

*Van Duym, D. P., 1954, The mineralogy of the (Upper Devonian) Grassy Creek and (Mississipplan) Saverton Formations (Missouri): M. S. thesis (unpub.), Missouri School of Mines.

Van Horn, F. R., and K. R. Van Horn, 1933, X-ray study of pyrite or marcasite concretions in the rocks of the Cleveland, Ohio quadrangle: American Mineralogist, v. 8, p. 288-294, 2 figs.

Crystallographic observations and $x$-ray analyses of iron sulfide concretions in the Devonian-Mississippian shales in the Cleveland district (after Hoover, 1960).

Ver Wiebe, W. A., 1918, The Devono-Carboniferous boundary rocks of Ohio, Pennsylvania, and New York: Ph. D. thesis (unpub.), Cornell University.

Walls, R. A., 1972, Sedimentation, paleoecology, and paleogeography of Upper Devonian, Lower Mississippian silt and shale facies in the southeastern Appalachian Basin (abstr.), in Southeastern Section, 21st annual meeting, Geological Society of America, Abstract, v. 4, no. 2, p. 111.

Paleoenvironmental reconstruction of deltaic complex based on subsurface data.

Walls, R. A., 1975, Late Devonian and Early Mississippian subaqueous deltaic facies in a portion of the southeastern Appalachian basin, in Deltas, models for exploration (Broussard, M. L., ed.), p. 359-367, illus. (incl. sketch maps), Houston Geological Society, Houston, TX.

Yaleoenvironmental reconstruction of Late Devonian-Early Mississippian delta in southeastern Appalachian Basin from subsurface data. Black shales considered offshore marine facies.

White, D., and T. Stadnichenko, 1923, Some mother plants of petroleum in the Devonian black shales: Economic Geology, v. 18, p. 238-253, p1. 5-9. Considers the microscopic plant material of the Ohio Shale (Hoover, 1960).

Winchester, D. E., 1918, Results of dry distillation of miscellaneous shale samples: U.S. Geological Survey Bulletin 691-B, p. 52.

Reports the results of distillation of Ohio (Chattanooga) Shale from a road metal quarry at Irvine, Estill County, KY. This sample assayed 7 gallons per ton (Hoover, 1960). 


\section{Appendix C: Task milestones}

$$
\text { ERDA/E- (40-1) }-5203
$$

Illinois State Geological Survey

GEOLOGIC AND GEOCHEMICAL STUDIES OF THE NEW ALBANY GROUP (DEVONIAN BLACK SHALE) IN ILLINOIS TO EVALUATE ITS CHARACTERISTICS AS A SOURCE OF HYDROCARBONS

$$
\text { Ju1y 1, } 1976 \text { - September 31, } 1977
$$

\begin{tabular}{|c|c|c|c|c|c|c|c|c|c|c|c|c|c|}
\hline . & $\begin{array}{c}1976 \\
\text { Sept } \\
1\end{array}$ & $\begin{array}{c}\text { Oct } \\
1\end{array}$ & $\begin{array}{c}\text { Nov } \\
1\end{array}$ & $\begin{array}{c}\text { Dec } \\
1\end{array}$ & $\begin{array}{c}1977 \\
\text { Jan } \\
1\end{array}$ & $\begin{array}{c}\text { Feb } \\
1\end{array}$ & $\begin{array}{c}\text { Mar } \\
1\end{array}$ & $\underset{1}{\mathrm{Apr}}$ & $\begin{array}{c}\text { May } \\
1\end{array}$ & $\begin{array}{c}\text { June } \\
1\end{array}$ & $\begin{array}{c}\text { July } \\
1\end{array}$ & $\begin{array}{c}\text { Aug } \\
1\end{array}$ & $\begin{array}{c}\text { Sept } \\
1\end{array}$ \\
\hline Tutle IG & & - & 1 & $?$ & $\begin{array}{l}3 \\
x\end{array}$ & $!, 12$ & 5.13 & $\begin{array}{c}6,14 \\
\pi\end{array}$ & 7,13 & $\dot{x}, i \dot{h}$ & $\begin{array}{l}9,1.7 \\
18 \\
\quad x x\end{array}$ & 10 & 11 \\
\hline Task IIG & & & . & & $\begin{array}{r}19 \\
x\end{array}$ & 20 & & $\begin{array}{r}21 \\
x\end{array}$ & 22 & 23 & $\mathbf{x x}$ & & 24 \\
\hline Task IIIG & & & & & $\begin{array}{r}25 \\
x\end{array}$ & & & $\begin{array}{r}26 \\
x\end{array}$ & 27 & 28 & $\mathbf{x x}$ & & \\
\hline Task IVG & & & & & $\mathbf{x}$ & & & $\mathbf{x}$ & & & $\mathbf{x x}$ & & \\
\hline Task IC & & & 1 & 2 & $\begin{array}{c}3,4 \\
\times \\
\end{array}$ & & & $\mathbf{x}$ & & & $\mathbf{x x}$ & & 5 \\
\hline Task IIC & & & & & & & & & & & & 6 & \\
\hline Task IIIC & 7 & & & & $\mathbf{x}$ & & & $\mathbf{x}$ & & 8 & $\mathbf{x x}$ & 9 & \\
\hline Task IVC & & 10 & 11 & & $\begin{array}{r}12 \\
x\end{array}$ & 13 & & $\mathbf{x}$ & & & $\mathbf{x x}$ & 14 & 15 \\
\hline
\end{tabular}

Kay to Milestones

$x \quad$ Quarterly report

xx Annual report. Effective date revised to September 30, 1977 (end of FY77).

Ccologic tagke (IG - IVG)

1. Complete bibliography of literature on New Albany of Illinois and adjacent states

2. Complete map showing LANDSAT linear features in fllinois

3. Complete two clectric log - 1ithologic cross-sections based on subsurface data in Survey files

4. Two additional cross-sections

5. Two additiona1 cross-sections

6. Two additional cross-sections

7. Two additional cross-sections

8. Three additional cross-sections 
9. Complete thickness map of New Albany in Illinois

10. Complete thickness maps of two subunits of New Albany

11. Complete thickness maps of two additional subunits of New Albany

12. Complete check of Devonian well file of basic data for southeast quarter of Illinois

13. Tabulate above data

14. Complete computer base map with Devonian tests for southeast quarter of Illinois

15. Complete oil and gas pool map for Devonian and Silurian in Illinois

16. Same as (12) for southwest quarter of Illinois

17. Same as (13) for southwest quarter of Illinois

18. Same as (14) for southwest quarter of Illinois

19. Complete acquisition and testing of reflectance-fluorescence equipment

20. Complete sample preparation, $x$-ray diffraction and radiography, microscopic analysis, and evaluation of core 1, Sangamon County, Illinois

21. Same for core 2, White County, I11inois

22. Same for core 3, White County, Illinois

23. Same for core 4, Henderson County, Illinois

24. Same for core 5, Christian County, Kentucky

25. Order acoustical bench, timer and printer, and compression machine

26. Install acoustical bench, test, and begin processing core samples

27. Install compression machine, test, and begin processing core samples

28. Complete all laboratory facilities and establishment of processes for. determining physical properties.

Geochemical tasks (IC - IVC)

1. Multichannel analyzer ordered

2. Multichannel analyzer received

3. Multichannel analyzer installed

4. Begin chemical analyses

5. Chemical analysis of 150 shales completed

6. Begin work on organic/inorganic trace element separations

7. Receipt of first canned shales for gas analysis

8. Analysis of 40 gas samples completed

9. Begin analysis of extractable shale hydrocarbons

10. Begin construction of pressure apparatus for gao adoorption

11. Begin internal surface area measurements for shale

12. Completion of construction of pressure apparatus

13. Testing of pressure apparatus

14. Completion of 50 internal surface area measurements

15. Completion of 10 methane adsorption isotherms 
Appendix D: Final Financial Statement, FY 77

(October 1, 1976-September 30, 1977)

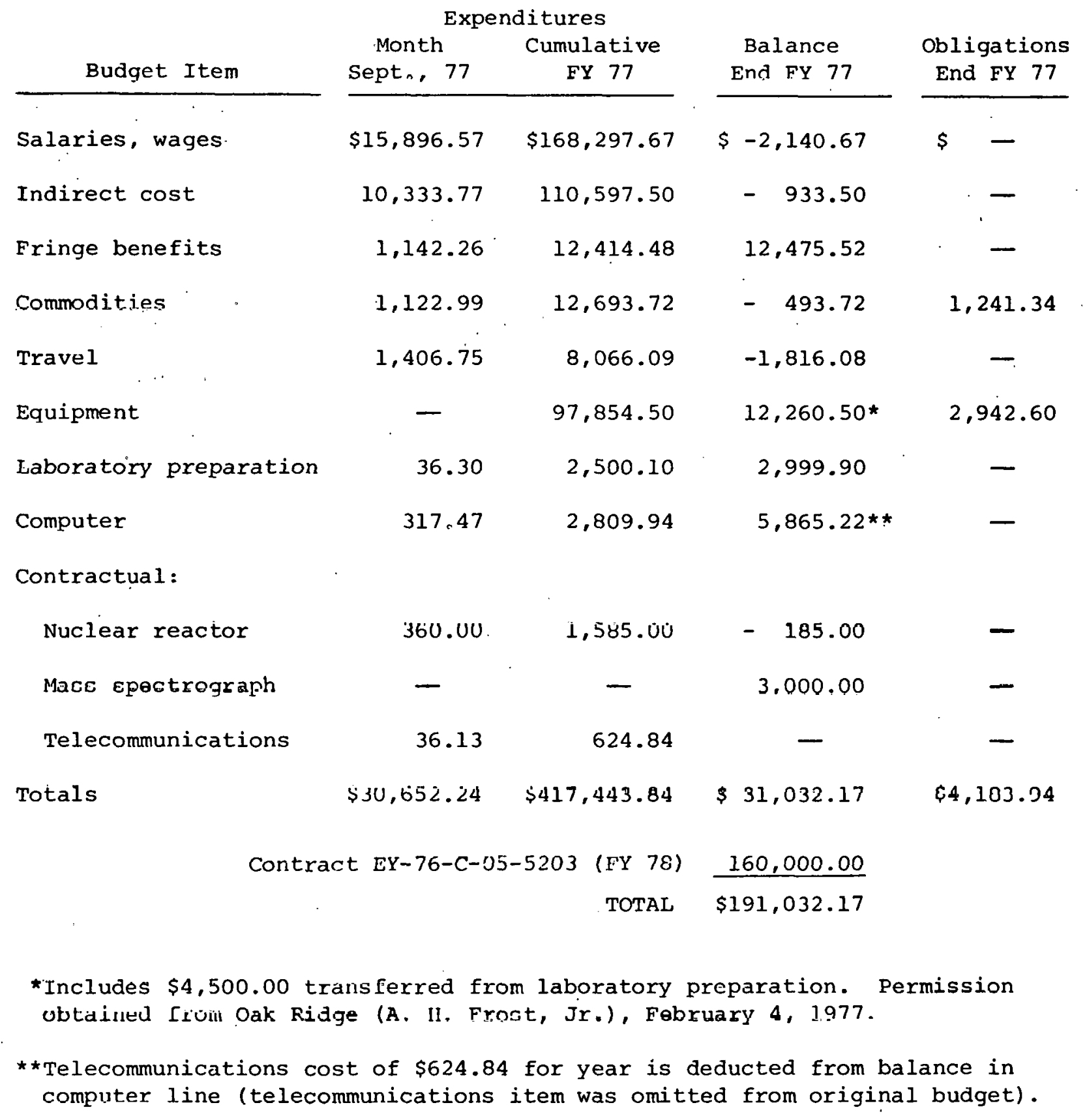

\&U.S. GOVERNMENT PRINTING OFFICE: 1978 - 740 - 306/94 94 REGION NO. 4 